\title{
Application of a statistical zonation technique to Granny Creek field in West Virginia
}

\author{
Venkata Kristamsetty \\ West Virginia University
}

Follow this and additional works at: https://researchrepository.wvu.edu/etd

\section{Recommended Citation}

Kristamsetty, Venkata, "Application of a statistical zonation technique to Granny Creek field in West Virginia" (2006). Graduate Theses, Dissertations, and Problem Reports. 1775.

https://researchrepository.wvu.edu/etd/1775

This Thesis is protected by copyright and/or related rights. It has been brought to you by the The Research Repository @ WVU with permission from the rights-holder(s). You are free to use this Thesis in any way that is permitted by the copyright and related rights legislation that applies to your use. For other uses you must obtain permission from the rights-holder(s) directly, unless additional rights are indicated by a Creative Commons license in the record and/ or on the work itself. This Thesis has been accepted for inclusion in WVU Graduate Theses, Dissertations, and Problem Reports collection by an authorized administrator of The Research Repository @ WVU. For more information, please contact researchrepository@mail.wvu.edu. 


\title{
APPLICATION OF A STATISTICAL ZONATION TECHNIQUE TO GRANNY CREEK FIELD IN WEST VIRGINIA
}

\author{
VENKATA KRIST AM SETTY
}

Thesis Submitted to the

\author{
College of E ngineering and M ineral R esources \\ at West Virginia University \\ in partial fulfillment of the requirements \\ for the degree of
}

\author{
M aster of Science \\ in \\ Petroleum and Natural Gas E ngineering
}

\author{
H. Ilkin Bilgesu, Ph.D., C hair \\ Samuel A meri, M.S. \\ Khashayar Aminian, Ph.D. \\ Daniel E. Della-Giustina, Ph.D. \\ Erdogan G unel, Ph.D.
}

Department of Petroleum and Natural G as Engineering

M organtown, West Virginia
2006

K eywords: Petroleum and $\mathrm{N}$ atural $\mathrm{G}$ as E ngineering, $\mathrm{H}$ ydraulic $\mathrm{F}$ low Unit, Statistical Z onation Technique, Granny C reek Field. 


\section{ABSTRACT}

\section{APPLICATION OF A STATISTICAL ZONATION TECHNIQUE TO GRANNY CREEK FIELD IN WEST VIRGINIA}

\section{VENKATA KRISTAM SETTY}

The significance of dividing the sedimentary intervals into flow units reflects groups of rocks that has similar geologic, physical properties and depositional environment that affect fluid flow. Variations in rock properties result from depositional, diagenetic and post-depositional changes. A flow unit is a volume of a reservoir rock that is continuous laterally and vertically and has similar averages of those rock properties that affect fluid flow.

In this study, a statistical zonation technique developed by Testerman to identify and describe naturally occurring zones in a reservoir is applied to Granny Creek field in West Virginia. This technique is particularly useful in describing a reservoir where crossflow between adjacent strata is important in determining reservoir behavior. We established a linear relationship between the core permeability and density from the log in the cored wells to predict the permeability of the uncored wells, allowing for extension of flow units to these wells. Then the flow units from well to well were correlated by statistical calculation. Although it has been used for permeability zonation, the technique is general and can be used to correlate any reservoir property. 


\section{Dedication}

Dedicated to my parents, who have provided me with support emotionally and financially throughout this long journey thousands of miles away from home. 


\section{Acknowledgement}

A journey is easier when you travel together. Interdependence is certainly more valuable than independence. This thesis is the result of two years of work whereby I have been accompanied and supported by many people. It is a pleasant aspect that I have now the opportunity to express my gratitude for all of them.

The first person I would like to thank is my research advisor Dr. H. Ilkin Bilgesu. During these years I have known Dr. Bilgesu as a sympathetic and principle-centered person. His overly enthusiasm and integral view on research and his mission for providing "only high-quality work and not less”, has made a deep impression on me. I owe him a great deal of gratitude for having me shown this way of research. I am really happy that I have come to know Dr. Bilgesu during my life.

My appreciation to Professor Sam Ameri, Chairman of the Petroleum and Natural Gas Engineering Department who kept an eye on the progress of my work and was available when I need his advice during my stay at West Virginia University.

I would like to thank Dr. Aminian for his contributions from time to time during my research and through the courses taken with him during the course of my study.

Special thanks to Dr. Daniel Della-Giustina for his encouragement and participation on the examining committee. 
I would also like to thank Dr. Erdogan Gunel for his participation in the examining committee.

Last, but not least, I thank my parents for giving me life in the first place, for educating me with aspects, for unconditional support and encouragement to pursue my interests, even when the interests went beyond boundaries of language, field and geography. 


\section{TABLE OF CONTENTS}

\section{Page}

$\begin{array}{lll}\text { ABSTRACT } & \text { ii }\end{array}$

$\begin{array}{ll}\text { DEDICATION } & \text { iii }\end{array}$

ACKNOWLEDGEMENTS

LIST OF FIGURES $\quad$ ix

LIST OF TABLES Xiv

NOMENCLATURE Xix

CHAPTER 1. INTRODUCTION 1

CHAPTER 2. LITERATURE REVIEW 4

2.1 Concept of Flow Units. 4

2.2 Flow Unit Identification Techniques. 4

2.2.1 Flow Unit classification using core data. $\quad 4$

2.2.1.1 Histogram Approach. 5

2.2.1.2 Probability Plot Approach. 6

$\begin{array}{ll}\text { 2.2.1.3 Nonlinear Regression. } & 7\end{array}$

$\begin{array}{ll}\text { 2.2.1.4 Ward } \square \text { s Algorithm. } & 7\end{array}$

2.2.1.5 Hydraulic Unit Prediction Using Log Data. $\quad 8$

2.3 Statistical Zonation Technique. 9

$\begin{array}{lr}2.4 \text { Related Studies. } & 12\end{array}$

CHAPTER 3. OBJECTIVE \& METHODOLOGY 16 
3.1 Description of the field.

3.2 Data Collection.

\section{CHAPTER 4. RESULTS AND DISCUSSION}

4.6 Discussion of results from Test 6.

4.7 Discussion of results from Test 7. 45 
4.9 Discussion of results from Test 9.

4.10 Discussion of results from Test 10 . 51

4.11 Correlation of flow units using measured permeability data 53 from cored wells.

4.12 Correlation of flow units using predicted permeability data 58 for Uncored wells.

CHAPTER 5. CONCLUSIONS AND RECOMMENDATIONS

REFERENCES $\quad 64$

Appendix A. Distribution of Density from the log and Core Permeability 66 in cored wells.

Appendix B. Permeability predictions in cored wells using transformation approach.

Appendix C. Determination of Flow Unit by Statistical Zonation Technique using core permeability.

Appendix D. Determination of Flow Unit by Statistical Zonation Technique using predicted permeability for cored wells.

Appendix E. Determination of Flow Unit by Statistical Zonation Technique using predicted permeability for Uncored Wells.

Appendix F. Sample Calculation for correlation of flow units for both cored wells and wells without cores. 


\section{LIST OF FIGURES}

Figure 3.1 Location of Granny Creek Field in West Virginia. 18

Figure 3.2 Location of Ten Cored Wells in the Granny Creek Field. 20

Figure 3.3 Location of Fifteen Uncored Wells in the Granny Creek Field. 21

Figure 3.4 Plot of Density versus Log K data taken from well 15-1184. 24

Figure 3.5 Plot of Density versus Log K data taken from ten core wells. 27

Figure 4.1.1 Comparison of Measured and Predicted permeability values for 34 well 15-733.

Figure 4.1.2 Comparison of flow units for well 15-733 based on mean permeability from measured and predicted values.

Figure 4.2.1 Comparison of Measured and Predicted permeability values for 36 well 15-1059.

Figure 4.2.2 Comparison of flow units for well 15-1059 based on mean permeability from measured and predicted values.

Figure 4.3.1 Comparison of Measured and Predicted permeability values for well 15-1107.

Figure 4.3.2 Comparison of flow units for well 15-1107 based on mean permeability from measured and predicted values.

Figure 4.4.1 Comparison of Measured and Predicted permeability values for well 15-1108.

Figure 4.4.2 Comparison of flow units for well 15-1108 based on mean permeability from measured and predicted values.

Figure 4.5.1 Comparison of Measured and Predicted permeability values for well 15-1109.

Figure 4.5.2 Comparison of flow units for well 15-1109 based on mean permeability from measured and predicted values.

Figure 4.6.1 Comparison of Measured and Predicted permeability values for well 15-1128.

Figure 4.6.2 Comparison of flow units for well 15-1128 based on mean 
permeability from measured and predicted values.

Figure 4.7.1 Comparison of Measured and Predicted permeability values for 46 well 15-1130.

Figure 4.7.2 Comparison of flow units for well 15-1130 based on mean permeability from measured and predicted values.

Figure 4.8.1 Comparison of Measured and Predicted permeability values for 48 well 15-1132.

Figure 4.8.2 Comparison of flow units for well 15-1132 based on mean permeability from measured and predicted values.

Figure 4.9.1 Comparison of Measured and Predicted permeability values for well 15-1184.

Figure 4.9.2 Comparison of flow units for well 15-1184 based on mean permeability from measured and predicted values.

Figure 4.10.1 Comparison of Measured and Predicted permeability values for well 15-1309.

Figure 4.10.2 Comparison of flow units for well 15-1309 based on mean permeability from measured and predicted values.

Figure 4.11.1 Correlation of flow units from measured permeability data for wells 15-1309, 15-1184, 15-1107 and 15-1108.

Figure 4.11.2 Correlation of flow units from measured permeability data for wells 15-1109, 15-1132 and 15-1108.

Figure 4.11.3 Correlation of flow units from measured permeability data for wells 15-1128, 15-1130 and 15-1108.

Figure 4.11.4 Correlation of flow units from measured permeability data for wells 15-733, 15-1128, 15-1132 and 15-1107.

Figure 4.12.1 Correlation of flow units from predicted permeability data for wells 15-1110, 15-874 and 15-868.

Figure 4.12.2 Correlation of flow units from predicted permeability data for wells 15-1621, 15-1639 and 15-1783.

Figure 4.12.3 Correlation of flow units from predicted permeability data for wells 15-2150, 15-2215 and 15-1639. 
Figure 4.12.4 Correlation of flow units from predicted permeability data for wells 15-1176 and 15-1225.

Figure A. 1 Density from the Log and Core Permeability distribution for well 15-733.

Figure A. 2 Density from the Log and Core Permeability distribution for well 15-1059.

Figure A. 3 Density from the Log and Core Permeability distribution for well 15-1107.

Figure A. 4 Density from the Log and Core Permeability distribution for well 15-1108.

Figure A. 5 Density from the Log and Core Permeability distribution for well 15-1109.

Figure A. 6 Density from the Log and Core Permeability distribution for well 15-1128.

Figure A. 7 Density from the Log and Core Permeability distribution for well 15-1130.

Figure A. 8 Density from the Log and Core Permeability distribution for well 15-1132.

Figure A. 9 Density from the Log and Core Permeability distribution for well 15-1184.

Figure A. 10 Density from the Log and Core Permeability distribution for well 15-1309.

Figure B.1 Linear correlation between density from well log and logarithm of core permeability from Test 1 (except 15-733).

Figure B. 2 Permeability prediction for well 15-733. 73

Figure B.3 Linear correlation between density from well log and 74 logarithm of core permeability from Test 2 (except 15-1059).

Figure B. 4 Permeability prediction for well 15-1059. 74

Figure B.5 Linear correlation between density from well log and 75 logarithm of core permeability from Test 3 (except 15-1107).

Figure B. 6 Permeability prediction for well 15-1107. 
Figure B.7 Linear correlation between density from well log and

logarithm of core permeability from Test 4 (except 15-1108).

Figure B. 8 Permeability prediction for well 15-1108. 76

Figure B.9 Linear correlation between density from well log and 77

logarithm of core permeability from Test 5 (except 15-1109).

Figure B. 10 Permeability prediction for well 15-1109. 77

Figure B.11 Linear correlation between density from well log and 78

logarithm of core permeability from Test 6 (except 15-1128).

Figure B.12 Permeability prediction for well 15-1128. 78

Figure B.13 Linear correlation between density from well log and 79

logarithm of core permeability from Test 7 (except 15-1130).

Figure B. 14 Permeability prediction for well 15-1130. 79

Figure B.15 Linear correlation between density from well log and 80

logarithm of core permeability from Test 8 (except 15-1132).

Figure B. 16 Permeability prediction for well 15-1132. 80

Figure B.17 Linear correlation between density from well log and 81

logarithm of core permeability from Test 9 (except 15-1184).

Figure B. 18 Permeability prediction for well 15-1184. 81

Figure B.19 Linear correlation between density from well log and 82

logarithm of core permeability from Test 10 (except 15-1309).

Figure B. 20 Permeability prediction for well 15-1309. 82

Figure C. 1 Flow Unit identification in well 15-733. 98

Figure C. 2 Flow Unit identification in well 15-1059. 98

Figure C. 3 Flow Unit identification in well 15-1107. 99

Figure C. 4 Flow Unit identification in well 15-1108. 99

Figure C. 5 Flow Unit identification in well 15-1109. 100

Figure C. 6 Flow Unit identification in well 15-1128. 100

Figure C. 7 Flow Unit identification in well 15-1130. 101

Figure C. 8 Flow Unit identification in well 15-1132. 101

Figure C. 9 Flow Unit identification in well 15-1184. 102

Figure C. 10 Flow Unit identification in well 15-1309. 102 
Figure D. 1 Flow Unit identification with predicted permeability in well 15-733.

Figure D. 2 Flow Unit identification with predicted permeability in well 15-1059.

Figure D. 3 Flow Unit identification with predicted permeability in well 15-1107.

Figure D. 4 Flow Unit identification with predicted permeability in well 15-1108.

Figure D. 5 Flow Unit identification with predicted permeability in well 15-1109.

Figure D. 6 Flow Unit identification with predicted permeability in well 15-1128.

Figure D. 7 Flow Unit identification with predicted permeability in well 15-1130.

Figure D. 8 Flow Unit identification with predicted permeability in well 15-1132.

Figure D. 9 Flow Unit identification with predicted permeability in well 15-1184.

Figure D. 10 Flow Unit identification with predicted permeability in well 15-1309. 


\section{LIST OF TABLES}

Table 3.1 Number of available core permeability data for ten cored wells 25

Table 3.2: $\quad$ Lists of ten different tests performed. 26

Table C. 1 Flow Unit calculation for well 15-733 into two zones. 84

Table C. 2 Flow Unit calculation for well 15-733 into three zones. 84

Table C. 3 Flow Unit calculation for well 15-1059 into two zones. 85

Table C. 4 Flow Unit calculation for well 15-1107 into two zones. 85

Table C. 5 Flow Unit calculation for well 15-1107 into three zones. 86

Table C. $6 \quad$ Flow Unit calculation for well 15-1107 into four zones. 86

Table C. 7 Flow Unit calculation for well 15-1108 into two zones. 87

Table C. $8 \quad$ Flow Unit calculation for well 15-1108 into three zones. 88

Table C. $9 \quad$ Flow Unit calculation for well 15-1108 into four zones. 89

Table C. 10 Flow Unit calculation for well 15-1109 into two zones. 90

Table C. 11 Flow Unit calculation for well 15-1109 into three zones. 90

Table C. 12 Flow Unit calculation for well 15-1128 into two zones. 91

Table C. 13 Flow Unit calculation for well 15-1128 into three zones. 91

Table C. 14 Flow Unit calculation for well 15-1130 into two zones. 92

Table C. 15 Flow Unit calculation for well 15-1130 into three zones. 92

Table C. 16 Flow Unit calculation for well 15-1132 into two zones. 93

Table C. 17 Flow Unit calculation for well 15-1132 into three zones. 93

Table C. 18 Flow Unit calculation for well 15-1184 into two zones. 94

Table C. 19 Flow Unit calculation for well 15-1184 into three zones. 95

Table C. 20 Flow Unit calculation for well 15-1184 into four zones. 96

Table C. $21 \quad$ Flow Unit calculation for well 15-1309 into two zones. 97

Table C. 22 Flow Unit calculation for well 15-1309 into three zones. 97

Table D. 1 Flow Unit calculation with Predicted K for well 15-733 104 into two zones.

Table D. 2 Flow Unit calculation with Predicted K for well 15-733 104 into three zones.

Table D. 3 Flow Unit calculation with Predicted K for well 15-1059 105 into two zones. 
Table D. 4 Flow Unit calculation with Predicted K for well 15-1107 into two zones.

Table D. 5 Flow Unit calculation with Predicted K for well 15-1107

106 into three zones.

Table D. 6 Flow Unit calculation with Predicted K for well 15-1107

106 into four zones.

Table D. 7 Flow Unit calculation with Predicted K for well 15-1108 into two zones.

Table D. 8 Flow Unit calculation with Predicted K for well 15-1108

108 into three zones.

Table D. 9 Flow Unit calculation with Predicted K for well 15-1108 into four zones.

Table D. 10 Flow Unit calculation with Predicted K for well 15-1109 into two zones.

Table D. 11 Flow Unit calculation with Predicted K for well 15-1109

110 into three zones.

Table D. 12 Flow Unit calculation with Predicted K for well 15-1128 into two zones.

Table D. 13 Flow Unit calculation with Predicted K for well 15-1128 into three zones.

Table D. 14 Flow Unit calculation with Predicted K for well 15-1130 into two zones.

Table D. 15 Flow Unit calculation with Predicted K for well 15-1130 into three zones.

Table D. 16 Flow Unit calculation with Predicted K for well 15-1132 into two zones.

Table D. 17 Flow Unit calculation with Predicted K for well 15-1132 into three zones.

Table D. 18 Flow Unit calculation with Predicted K for well 15-1184 into two zones.

Table D. 19 Flow Unit calculation with Predicted K for well 15-1184 
into three zones.

Table D. 20 Flow Unit calculation with Predicted K for well 15-1309 116 into two zones.

Table D. 21 Flow Unit calculation with Predicted K for well 15-1309 into three zones.

Table D. 22 Flow Unit calculation with Predicted K for well 15-1309 into four zones.

Table E. 1 Flow Unit calculation with Predicted K for well 15-868 into two zones.

Table E. 2 Flow Unit calculation with Predicted K for well 15-868 into three zones.

Table E. 3 Flow Unit calculation with Predicted K for well 15-874 into two zones.

Table E. 4 Flow Unit calculation with Predicted K for well 15-1110 into two zones.

Table E. 5 Flow Unit calculation with Predicted K for well 15-1110 into three zones.

Table E. 6 Flow Unit calculation with Predicted K for well 15-1176 into two zones.

Table E. 7 Flow Unit calculation with Predicted K for well 15-1176 into three zones.

Table E. 8 Flow Unit calculation with Predicted K for well 15-1225 into two zones.

Table E. 9 Flow Unit calculation with Predicted K for well 15-1225 into three zones.

Table E. 10 Flow Unit calculation with Predicted K for well 15-1243 into two zones.

Table E. 11 Flow Unit calculation with Predicted K for well 15-1243 into three zones.

Table E. 12 Flow Unit calculation with Predicted K for well 15-1621 into two zones. 
Table E. 13 Flow Unit calculation with Predicted K for well 15-1621 into three zones.

Table E. 14 Flow Unit calculation with Predicted K for well 15-1639 into two zones.

Table E. 15 Flow Unit calculation with Predicted K for well 15-1639 into three zones.

Table E. 16 Flow Unit calculation with Predicted K for well 15-1649 into two zones.

Table E. 17 Flow Unit calculation with Predicted K for well 15-1783 into two zones.

Table E. 18 Flow Unit calculation with Predicted K for well 15-1783 into three zones.

Table E. 19 Flow Unit calculation with Predicted K for well 15-2150 into two zones.

Table E. 20 Flow Unit calculation with Predicted K for well 15-2215 into two zones.

Table E. 21 Flow Unit calculation with Predicted K for well 15-2430 into two zones.

Table E. 22 Flow Unit calculation with Predicted K for well 15-2430 into three zones.

Table E. 23 Flow Unit calculation with Predicted K for well 15-2001 into two zones.

Table E. 24 Flow Unit calculation with Predicted K for well 15-2001 into three zones.

Table E. 25 Flow Unit calculation with Predicted K for well 87-2102 into two zones.

Table F.1 Rank of measured Core Permeability Means with ten cored wells in the order of decreasing magnitude.

Table F. 2 Comparison of the mean of flow unit 3 of well 15-1108.

Table F. 3 Comparison of the mean of flow unit 2 of well 15-1108.

Table F.4 Comparison of the mean of flow unit 2 of well 15-1130. 
Table F. 5 Final division of core permeability means into two groups.

Table F.6 Rank of predicted permeability means for fifteen wells with no cores in the order of decreasing magnitude.

Table F. 7 Comparison of the mean of flow unit 1 of well 15-1176.

Table F. 8 Comparison of the mean of flow unit 1 of well 15-2150.

Table F. 9 Final division of core permeability means into five groups. 


\section{NOMENCLATURE:}

B Variance between zones

Erf Error function

$\mathrm{F}^{*} \quad$ Measured cumulative distribution function

F(z) Distribution density function

$\mathrm{F}(\mathrm{z}) \quad$ Cumulative distribution, $0<\mathrm{F}<1$

$\mathrm{F}_{\mathrm{s}} \quad$ Shape factor

FU Flow Unit

FZI Flow zone indicator

HU Hydraulic Unit

i summation index for number of zones

j summation index for number of data within the zone

k Permeability, $\mathrm{mD}$

$\mathrm{k}_{\mathrm{i}} \quad$ Mean of the permeability data in the $\mathrm{i}^{\text {th }}$ zone, $\mathrm{mD}$

$\mathrm{k}$. Overall mean of the data in the well, $\mathrm{mD}$

$\mathrm{k}_{\mathrm{ij}} \quad$ Permeability data, $\mathrm{mD}$

$\mathrm{k}_{\mathrm{h}} \quad$ Arithmetic average of permeability data of the $\mathrm{h}^{\mathrm{th}}$ zone in one well

L Number of zones

i Mean of $i^{\text {th }}$ observation

$m_{i} \quad$ Number of data in the ith zone

$\mathrm{N} \quad$ Total number of data

$\mathrm{n}_{\mathrm{g}} \quad$ Number of cluster groups

$\mathrm{n}_{\mathrm{h}} \quad$ Number of data in the $\mathrm{h}^{\text {th }}$ zone 


\begin{tabular}{|c|c|}
\hline $\mathrm{n}_{\mathrm{i}}$ & Number of data in the $i^{\text {th }}$ zone \\
\hline $\mathrm{N}_{\mathrm{U}}$ & Number of hydraulic units \\
\hline$\Omega$ & Objective function of minimization \\
\hline $\mathrm{v}_{\mathrm{z}}$ & Pore volume to grain volume ratio \\
\hline RQI & Reservoir quality index \\
\hline $\mathrm{R}$ & Zonation index \\
\hline $\mathrm{S}$ & Standard deviation of all the permeability data of the reservoir \\
\hline $\mathrm{S}_{\mathrm{gv}}$ & Effective surface area per unit grain volume \\
\hline$\tau$ & Tortuosity \\
\hline$\omega \mathrm{i}$ & Weight of the HU distribution \\
\hline$\sigma \mathrm{i}$ & Standard deviation of the $i^{\text {th }}$ distribution \\
\hline $\mathrm{W}$ & Variance within zone \\
\hline $\mathrm{Z}$ & $\log (\mathrm{FZI})$ \\
\hline
\end{tabular}




\section{CHAPTER -1 \\ INTRODUCTION}

Accurate well correlations are paramount for a reliable reservoir characterization. All geologic modelling have their foundation in correlation work. Therefore, it is worth knowing that any geologic correlation that is not consistent with the reservoir $\square$ s physical properties will give a misrepresentation of different flow units. In constructing an appropriate model, it is important that both the "form" and "function" of the reservoir is honoured as much as possible. The form represents the geologic environment, rock type, and the reservoir architecture. The function represents the petrophysical properties that result in the flow performance. While the former is associated with the geologic zones, the latter on the other hand is associated with the quantitative statistical zonation.

One of the first problems encountered by the reservoir engineer in predicting or interpreting fluid displacement behavior during secondary processes is that of organizing and using the large amount of data available from core analysis. Permeabilities pose particular problems because they usually vary by more than an order of magnitude between different strata. Due to the sheer volume, it is almost always necessary to group data and to use an average value to represent a number of measurements. Perhaps the most common method now used to group permeability data is the capacity-friction technique, which ranks permeabilities in order of magnitude, regardless of the physical location of the permeabilities within the reservoir. 
Reservoir engineering techniques being developed will handle cross flow that occurs between adjacent communicating reservoir strata because of imbibitions and gravity segregation. Since crossflow occurs between physically adjacent layers within the reservoir, a flow unit technique recognizing the actual location of strata within the reservoir is necessary. Similarly, the recognition of natural flow unit is important for predictions of oil recovery by processes involving diffusion. One such process is miscible displacement, where predictions of lateral diffusion within the reservoir must recognize the actual location of the invaded zones in relation to the rest of the formation. Natural zones must also be adequately recognized to account for heat transfer within the reservoir during the thermal exploitation.

Because of the complexity of the problem, statistics appear to offer the only practical hope of dividing a reservoir into physically - meaningful natural flow units. This thesis presents a statistical zonation technique developed by Testerman ${ }^{1}$ to identify and describe porous and permeable zones in a reservoir, and for determining which ones are likely to be continuous between adjacent wells. The flow units defined have minimum variation of permeability internally and a maximum variation between zones. The technique is general and can thus be applied to reservoir properties other than permeability. However, a statistical correlation based on core permeabilities and density from the log in two different wells is no guarantee that the flow units so defined are, in fact continuous. Rather, the assumption of continuity must be consistent with geological data concerning the depositional environment, as well as justified on the basis of engineering 
judgment in combination with statistics, just as judgment is required with conventional zonation methods.

Although core data is not available for all wells since core analysis is expensive, a linear correlation has been made between core data and log data to predict permeability for uncored wells. The statistical method was utilized to identify the flow unit using the permeability data. The flow units from the predicted permeability and measured core permeability were correlated with each other throughout the reservoir. The technique is particularly useful in describing the reservoir where cross flow between adjacent strata is important in determining reservoir behavior. 


\section{CHAPTER-2}

\section{LITERATURE REVIE W}

\subsection{Concept of F low Units ${ }^{2}$}

In recent years, the concept of hydraulic unit or flow unit has been introduced as a method of subdividing a sedimentary interval for reservoir description. A flow unit is defined as a volume of reservoir rock that is continuous laterally and vertically and has similar averages of the rock properties that affect fluid flow. Flow units represent an assemblage of facies having similar characteristics and are related to geological facies distributions but do not necessarily coincide with the facies boundaries. The parameters that influence fluid flow are mainly pore-throat geometrical attributes. The pore geometry is in turn controlled by mineralogy (type, abundance, location) and texture (grain size, grain shape, sorting, packing). Various combinations of these geological properties can lead to distinct rock flow units that have similar fluid transport properties. The significance of dividing the sedimentary intervals into flow units is that each flow unit usually reflects a specific depositional environment and the characteristics of fluid flow.

\subsection{Flow Unit I dentification Techniques ${ }^{3,4}$}

\subsubsection{F low Unit classification using core data:}

Flow unit $\square$ s can be identified based on Flow Zone Indicator (FZI) values. Although there should exist one single FZI value for each flow unit, a distribution for each FZI values around its true mean results due to random measurement errors in core analysis. When multiple flow unit groups exist, the overall FZI distribution function is a superposition of 
the individual distribution function around their mean FZI. Identification of each mean FZI, or the corresponding Hydraulic Unit (HU), would require decomposition of the overall FZI distribution into its constituting elements. This is a desuperposition problem and cluster analysis techniques allow for such a decomposition process.

Three approaches, histogram analysis, probability plot, and the Ward $\llbracket$ s analytical algorithm, are discussed for cluster analysis, although there are other declustering procedures, such as dendrogram or rose diagram. ${ }^{5}$ The declustering of FZI is performed on the basis of logarithm of FZI because FZI values calculated from actual field data usually exhibit log-normal distribution. This can be attributed to the strong dependency of FZI on permeability, which in turn often is a log-normal Gaussian distribution.

\subsubsection{H istogram A pproach²:}

Because FZI distribution is a superposition of multiple log-normal distributions, a histogram of FZI (with the log scale in the x-axis) should show "n" number of normal distributions for “n” number of HU\s. The convolved frequency distribution for a mixture of multiple Gaussian probability density functions is described by Equations $1 \& 2$.

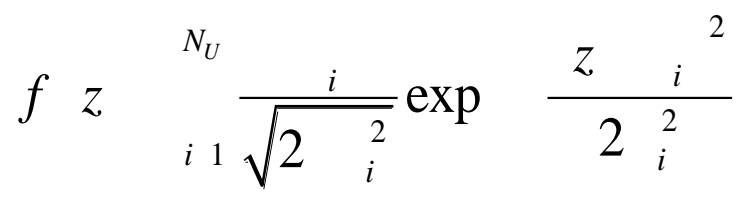

and

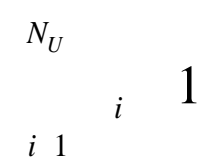


When clusters are distinctly separate, the histogram clearly delineates each HU and provides their corresponding FZI values. This is the easiest and simplest approach. However, it is often difficult to separate the overlapped individual distributions from a histogram plot. Therefore, this method is not suitable for most field applications because the transition zones between HU\s often clouds the judgment on their identity.

\subsubsection{Probability Plot A pproach²:}

It is also called as cumulative distribution function plot. It is the integral of histogram (probability density function), and as such, it is a smoother plot than histogram plot. In this plot the scatter in data is reduced and the identification of clusters is easier. The cumulative distribution function is given by Equation 3.

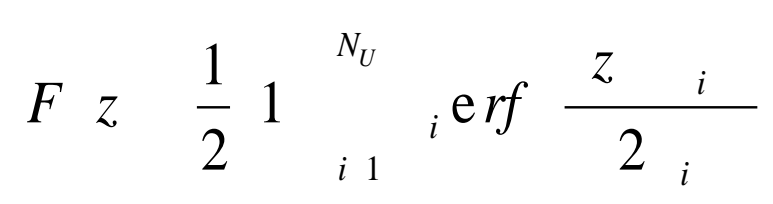

where erf is the "error function" encountered in the integration of normal distribution.

The number of straight lines and the limiting boundary values of FZI or each HU can be obtained from the probability plot of Log (FZI). Because mean FZI values are not calculated from the probability plots, the representative FZI value for each $\mathrm{HU}$ is obtained by averaging all the FZI values within the corresponding HU limits. This exactly corresponds to a linear least-squares regression of data where the slope of the regression line is equal to unity. This method is more useful than histogram method 
because it is easier to identify straight lines visually, although the superposition effects may shift or distort the straight lines to some degree.

\subsubsection{Nonlinear R egression ${ }^{2}$ :}

Because FZI distribution function is a complex convolution of multi-Guassian distributions, nonlinear regression analysis offers a robust means for decomposing such a multimodal distribution. In this approach, an objective function is minimized and the unknown parameters of mean and standard deviation of the comprising distribution functions are obtained. The objective function is defined by Equation 4.

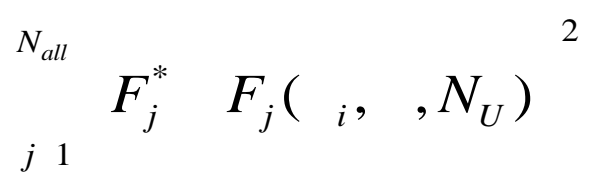

Equivalently, the regression can also be done on the histogram data. Any standard nonlinear regression algorithm ${ }^{6}$ can be used to optimize ,Q\. The mean of individual distribution functions corresponds to the FZI values of each HU. It is also possible to regress on the number of $\mathrm{HU} \square$ s as an unknown parameter.

\subsubsection{Ward's Algorithm?:}

The Ward $\llbracket$ s algorithm is an analytical technique in hierarchical cluster analysis. In this method, the distance between data points (FZI values) are calculated, initially treating each sample data as a cluster. Next, the two clusters that are closest in distance are merged and the distance of new clusters from other clusters is computed. The process of distance calculation and emerging of clusters is continued until all available data points are emerged or until the required number of clusters is attained. The number of clusters is 
an input into the Ward $\llbracket$ s algorithm. Graphical methods, especially the probability plot, provide a good means to determine an appropriate number of HUls for a data set. One of the advantages of the Ward $\square$ s algorithm over the others is its special treatment of the cluster variances. Clusters are formed so as to minimize the increase in the within-cluster sums of squares of deviations from their mean. The distance between two clusters causes an increase in the sum of squares if the two clusters were emerged. Therefore, each cluster tends to attain a minimum spread around its mean value while having maximum separation from the other clusters. This is exactly what is expected from a HU. The within-group sum of squared deviations is calculated using Equation 5. $w \quad n_{i} n_{j} n_{i} z_{i j} \quad-2$

\subsubsection{H ydraulic Unit Prediction Using Log Data:}

The major task is to predict HU■s in wells where only well log measurements are available. This is an inverse process that requires a probabilistic approach. Three steps are needed for the inference of $\mathrm{HU}$ distribution at logged wells. First, those logs that are sensitive to dynamic flow parameters of pore-throat attributes are identified. This is done by either assessing the degree of correlatability of various logs with permeability or FZI through rank correlation, or by performing principal component analysis. The second step involves constructing a training data base that captures information on the interrelationship between logs and HU\s. The third step uses the database information and well log measurements to infer distribution of HU\s statistically along the logged wells. The above three steps are discussed below in more detail. 
Amaefule $^{3}$ presented a theoretical methodology to identify the flow units. He defined a concept called Flow Zone indicator, FZI, which classifies the flow units in a reservoir. FZI is defined by the flowing Equation 6.

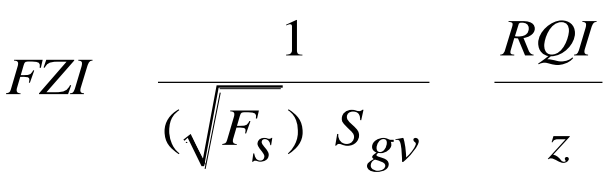

where $F_{\mathrm{s}}$ is the pore throat shape factor, $\tau$ is the tortuosity, and $\mathrm{S}_{\mathrm{gv}}$ is the effective surface area per unit grain volume. RQI is the reservoir quality index defined by Equation 7. RQI $\quad 0.0314 \sqrt{\frac{K}{z}}$

where $\mathrm{v}_{\mathrm{z}}$ is the pore volume to grain volume ratio is calculated using Equation 8 .

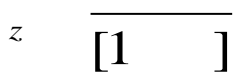

The above parameters are derived from a modified form of the Kozeny-Carmen equation.

\subsection{Statistical Zonation Technique:}

A Statistical Zonation Technique has been successfully used to detect significant differences between samples. The object in the problem of zonation is to detect the existence of distinct vertical sections or flow units within the permeability profile of each well in the reservoir.

The reservoir zonation technique is a two-step operation.

1. Permeability data from the top to bottom of the strata of a single well are divided into two zones. These zones are selected such that the variation of permeability within the 
zones is minimized and maximized between zones. The statistical equations ${ }^{7}$ used to zone the permeability data are:

$$
\begin{aligned}
& \text { B } \frac{1}{\mathrm{~L} 1} \mathrm{~m}_{\mathrm{i}}\left(\overline{\mathrm{k}}_{\mathrm{i}} \overline{\mathrm{k}}_{. .}\right)^{2} \\
& \frac{1}{L 1} \sum_{i 1}^{L} \frac{{ }_{j 1}^{m_{i}} k_{i j}^{2}}{m_{i}} \frac{{ }^{L} 1 j 1 k_{i j}^{m_{i}}}{N}
\end{aligned}
$$

The variance within any zone, $\mathrm{W}$, is computed from:

$$
\begin{aligned}
& W \quad \frac{1}{N \quad L} m_{i 1}^{m_{j 1}^{m_{i}}}\left(\bar{k}_{i} \bar{k}_{. .}\right)^{2}
\end{aligned}
$$

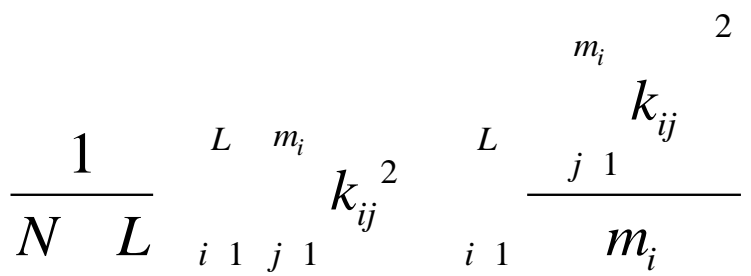

Zonation index, $\mathrm{R}$, is

$$
R \frac{B W}{B}
$$


The zonation of individual wells is a multi-step procedure:

(a) First, the permeability data, in their original order of depth, are divided into all possible combinations of two zones. Then, Equation 9, Equation 10 and Equation 11, are used to calculate for each of these possible two zone combinations. The zonation index calculated from equation 11 is the criterion used to indicate the best division. R, which ranges between 0 and 1 , indicates how closely the division corresponds to homogeneous zones. The closer $\mathrm{R}$ is to 1 , the more homogeneous are the zones. The larger $\mathrm{R}$ value denotes the best division into two zones, is retained for comparison with other indices. Any negative values of $\mathrm{R}$ are replaced by zero in order to conform to the definition of $\mathrm{R}$. (b) The permeability data of the best two-zone combination are divided into all possible three-zone combinations. The zonation index $\mathrm{R}$ is again calculated for determining the best three-zone division.

(c) The permeability data of the three-zone combinations are divided into all possible four-zone combinations. Then the zonation index criterion is applied.

The division into additional zones continues until the difference between two successive indices, $\Delta \mathrm{R}$, is negligible. In this study the difference is negligible if $\mathrm{R}<0.005$.

2. After all the wells in the reservoir have been zoned, the zones between adjacent wells are correlated for determining which strata are likely to be continuous, i.e., connected. The correlation is based on a statistical comparison of the difference of means of two zones in adjoining wells with the difference that could be expected from variation of measurements within zones. Zones are considered to correlate or connected if the 
difference in mean permeability of two zones in adjoining wells is less than or equal to that expected from variations of measurements within zones.

\subsection{R elated Studies:}

Estimation of permeability in uncored but logged wells is a generic problem common to all reservoirs. Any field-scale reservoir characterization study inevitably requires knowledge of petrophysical properties at drilled wells for its starting point. Therefore, scientifically sound and geologically compatible procedures must be sought to allow for reliable calculation of permeability distributions in wells. In this section we discuss some of the previous work done in estimating the permeability and reservoir zonation techniques.

Molnar $^{8}$ developed a methodology by integrating actual well log responses ( Gamma Ray, Deep Induction and Bulk Density) and geological interpretations to subdivide the formation into several zones which led to development of a reliable correlation between bulk density and permeability. Granny Creek field in West Virginia has been selected as the study area. In their study core data was available from 21 wells in the Granny Creek field and seven of these wells were selected for analysis. Well log data was collected from these wells, and the core data was adjusted to log depth by correlation of log and core porosity. Zones were then identified and delineated based on current stratigraphic, depositional environment and lithofacies interpretations. This approach enabled the development of a statistically viable permeability correlation which was verifiable by concurring analyses and permeability measurements of additional wells. 
Lacentre et $\mathrm{al}^{9}$ developed a methodology to estimate permeabilities in uncored wells based on available well $\operatorname{logs}$ and core data. The analysis includes a first step consisting of the interpretation of the petrophysics and a characterization in lithofacies, electrofacies and hydraulic flow units. The method takes advantage of modern mathematical tools that have proved to be effective in other fields of science and engineering, including neural networks, cluster analysis, principal component analysis. The method assumes that the Carman-Kozeny equation holds for the reservoir rocks, which is a fairly reasonable assumption, and that the well logs available contain intrinsic information on tortuosity, sand size distribution, cementing characteristics, etc., which ultimately determine the flow performance of the rock. In this method the permeability is related to the porosity and the flow zone indicator (FZI). The method was tested using available core and log data in a sandstone formation in Chihuido de la Salina, Neuquen Basin, Argentina.

Lawal and Onyekonwu ${ }^{10}$ developed a novel approach to delineate flow units. The approach is general, robust and relies on commonly available data. The method is predicted on the following three principles:

1. Parameterization

2. Cluster analysis

3. Discriminant analysis

In this method a unique parameter, the Flow Unit Delineator (FUD) has been developed for identifying flow units. This method is applied on a field in the Niger Delta Basin, Nigeria and the results show that it is more superior than other existing methods. 
Mustafa $^{11}$ developed a model to estimate permeability. In this study a linear relationship is developed between density from the log and core permeability data from six wells. Statistical Zonation technique is used to identify flow units in wells with core permeability data and the accuracy of the methodology was verified by comparing the original flow units with the predicted flow units in the wells with core data. JacksonburgStringtown field was selected and data from six core wells is used for this study.

Gunter et $\mathrm{al}^{12}$ and others developed graphical tools that would determine the number of flow units within the reservoir. This method requires continuous core porosity, permeability and saturation data for the entire horizon. The researchers considered the flow unit to be a stratigraphically continuous layer of similar reservoir characteristics that maintains the geologic frame work of rock types. The rock type is considered to be reservoir units having distinct porosity-permeability relationships and unique water saturations for the position in the reservoir above the free water level. A given rock type would be deposited under similar processes and experienced similar digenetic processes resulting a unique permeability-porosity relationship.

Thomas $^{13}$ developed a methodology for reservoir characterization via flow unit identification which is applicable to any field having limited data. This methodology utilizes limited core permeability data from a few wells as a key to predicting flow units within a field when only log based data is available. Various techniques for flow unit identification including graphic approaches using the permeability-porosity relationship within a given flow unit and ANN (Kohonen) analysis are utilized as a part of the 
methodology developed. The core data and flow units are utilized in neural network models designed to predict flow units and permeability field-wide using only electric well logs. Jacksonburg-Stringtown field was selected for this study.

Alla ${ }^{14}$ used simulation of waterflood performance to verify the characterization of flowunits in a heterogeneous reservoir. BOAST98 software was used for simulation of waterflood performance. Two adjacent five spot patterns in the Stringtown field in West Virginia were selected to be evaluated in this study. The predicted permeability along with the porosity from Artificial Neural Network (A.N.N) was used for primary characterization purpose and identification of flow-units in the two five spots patterns. Two alternate simulation models were developed. The simulation model was developed using the available data and those predicted using A.N.N. to verify that the flow-units model was an accurate description of the field. One model had two layers representing two flow units whereas the second model had three layers representing three flow units. The output from the simulation runs was compared with 10 years of actual production history of both the wells. A close history matching was obtained with about $15-25 \%$ of total volume water injection rates into the individual patterns from each of the 6 wells. Though both models were effective in predicting the output, the results with the second model which was developed for three flow units yielded better results. 


\section{CHAPTER-3}

\section{OBJECTIVE \& METHODOLOGY}

Although there are many techniques to characterize a reservoir, statistical technique is very important to identify and describe naturally occurring flow units in a reservoir and to correlate these flow units from well to well. The technique is particularly useful in describing a reservoir where cross flow between adjacent strata is important in determining reservoir behavior. Permeabilities play an important role to determine flow units in a reservoir. Due to the sheer volume, it is always necessary to group data and to use an average value to represent a number of measurements. Flow unit computation is derived from the permeability data. But permeability at all depth level, at all wells is not available and not practical to measure. Hence, this study aims to economically predict permeability from available density and limited core data. The predicted permeability is used to correlate flow units from well to well. Core permeability data plays an important role in characterizing a reservoir. But core data is usually not available for all the wells in the reservoir.

The main objectives of this study are to

$>$ Perform statistical calculation to identify flow units from original core permeability data.

$>$ Develop a model to predict permeability from density from the log and limited core permeability data.

$>$ Identify flow units from the predicted permeability.

Validate the model by comparing predicted flow units against original flow units. 
Develop a model to predict the permeability for limited uncored wells from density from the Log and limited core permeability data and identify flow units from predicted permeability.

Perform statistical correlation between the flow units throughout the reservoir for both cored and uncored wells.

\subsection{Description of the field ${ }^{15}$ :}

Granny Creek field is located in Clay and Roane counties, West Virginia, (Figure 3.1), and produces from the Lower Mississippian Big Injun sandstone, a prolific oil producer (nearly 60 fields) in West Virginia. Shallow oil reservoirs, like Granny Creek field, typically have been developed as if they were homogeneous. The field is located approximately 25 miles northeast of Charleston, West Virginia. The field was developed over a period of nearly 30 years beginning in 1924. Production has continued throughout most of the field until the present day. The field is roughly five miles long, has a maximum width of a little over two miles, and has a total productive area of about 3,000 acres. The well spacing commonly is 400 feet. The crude oil in Granny Creek field is a paraffin base, Pennsylvania Grade oil. It has a viscosity of $3.14 \mathrm{cp}$ and a liquid gravity of 45. $4^{\circ}$ API. Total oil production is estimated to be between $6,500,000$ and $6,750,000$ barrels. During the $1970 \llbracket$ s and early $1980 \llbracket$ s, the water flooding operations in Granny Creek Field were initiated. The water flooding has been moderately successful. However, the areal and vertical sweep efficiencies have been poor due to the heterogeneous nature of the formation. An enhanced recovery $\mathrm{CO}_{2}$ pilot project was conducted beginning 
in 1976. Because of the heterogeneous nature of the reservoir, less that 4 percent of the injected $\mathrm{CO}_{2}$ entered the pattern. Even this small amount was responsible for the production of over 4000 barrels of oil from within the pattern. This recovery was considered very good under the circumstances. A minitest $\mathrm{C}_{2}$ project was conducted in a part of the same pattern several years later with a small amount of oil recovery.

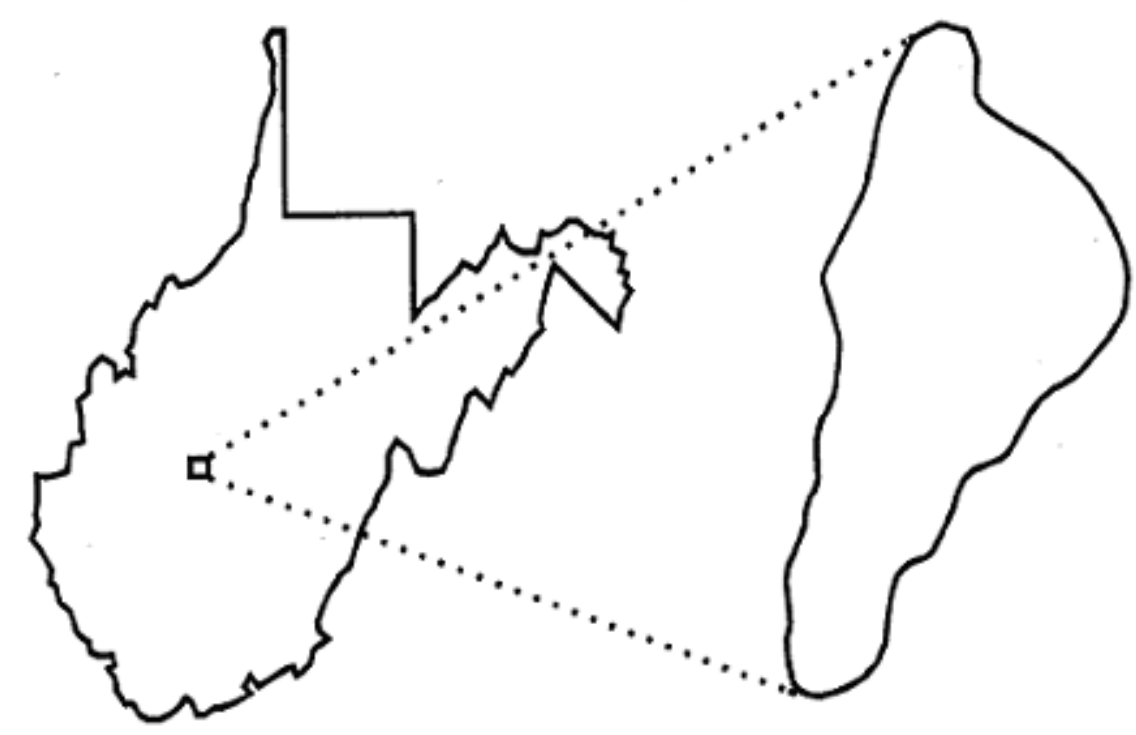

Figure 3.1 L ocation of Granny C reek Field in W est Virginia

The data pertaining to the structure, stratigraphy, and petrography of the Granny Creek Big Injun sandstone reservoir is presented. The field is located structurally on the northwest flank of a syncline and is surrounded to the west, south, and southeast by fields producing from the same interval. The western extent of the field might be limited by a gas cap, and the northeast extent is limited by erosional thinning of the reservoir.

The Big Injun has been divided into an upper-coarse grained fluvial channel facies and a lower fine-grained distributary mouth bar facies. The diagenetic features in the upper and 
lower parts of the fluvial channel facies are sufficiently different to warrant the further subdivision into A and B members. Generally the porosity in the upper A member is preserved because of chlorite grain coating, while quartz cementation in the lower B member has resulted in reduced porosity and permeability. Erosion has removed the A and B members eastward across the field.

The lower fine-grained distributary mouth bar facies, or C member, laterally consists of prograding tongues, numbered from oldest to youngest, as $\mathrm{C} 1, \mathrm{C} 2, \mathrm{C} 3$. The $\mathrm{C}$ member and its tongues represent a facies deposited in a deltaic river-mouth bar environment, and the subfacies are the proximal and distal portions of the bar which are further differentiated by domination of fluvial or marine processes. The completion records indicate zone $\mathrm{C} 2$ within the Big Injun formation as the major producer.

\subsection{Data Collection ${ }^{16}$ :}

The data for this field has been provided by "West Virginia Geological Survey" used in prior projects \& presented in other publications. Data is analyzed from cores and logs.

\subsubsection{C ore Data:}

A limited number of wells had cores from Big Injun formation. The results of core analysis were available from 20 wells. The core analysis included porosity, oil and water saturations, horizontal and vertical permeabilities, and horizontal permeability at $90^{\circ}$. Although core analysis is available for 20 wells we choose only 10 wells (Figure 3.2) for 
this study because of incompleteness in their data and their irrelevancies due to very low permeabilities.

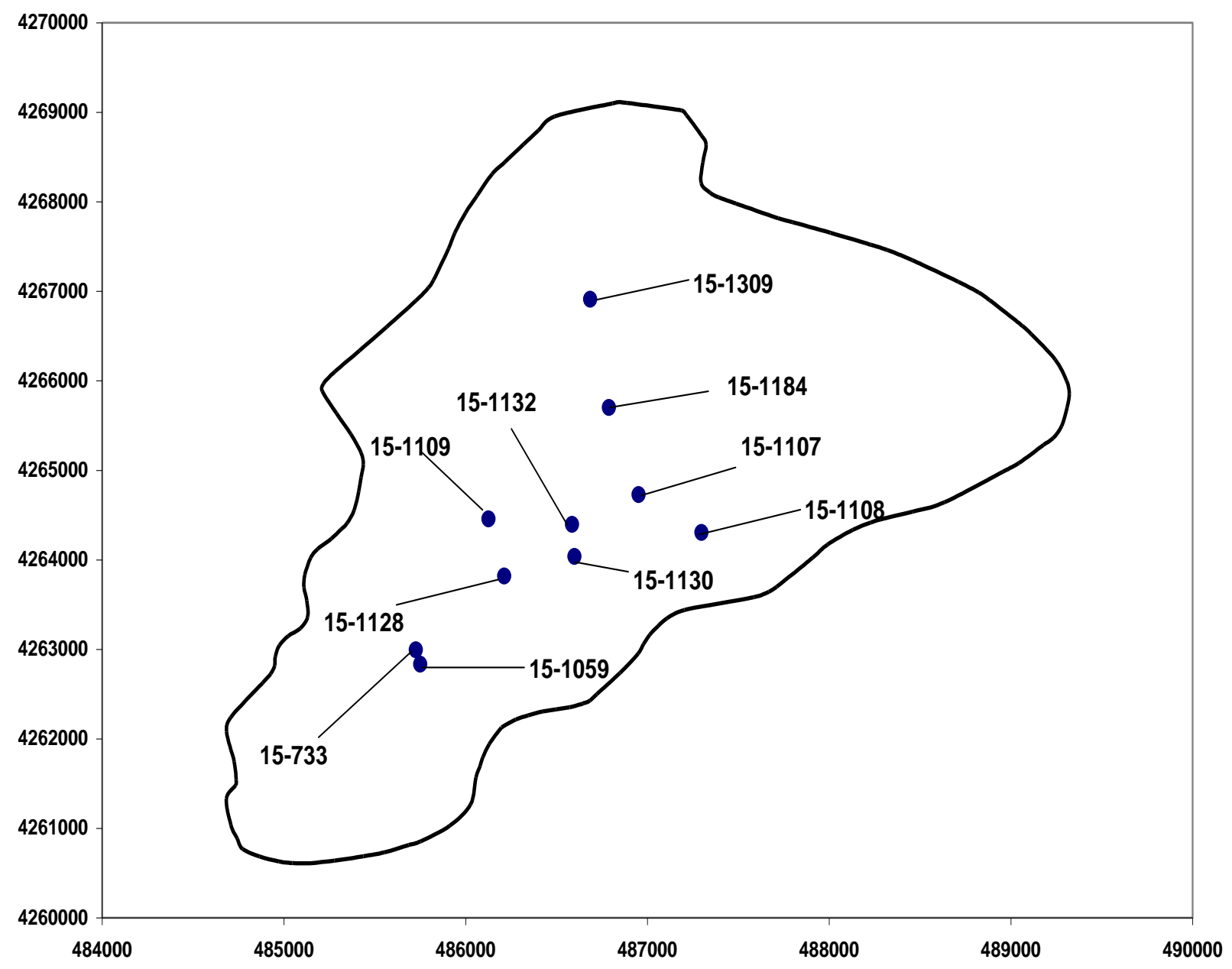

Figure 3.2: Location of Ten C ored Wells in the Granny C reek Field

\subsubsection{Log Data:}

Logs run in the field include Gamma Ray (GR), Density (RHOB), Neutron Porosity and Induction Logs. However, only Density Log was used in this study because of their availability in the studied wells and the readings were recorded for every quarter feet. In this study, average density log data for every single foot depth has been taken to identify 
the flow units by statistical method. From the available data we have chosen 15 wells (Figure 3.3) for this study from different locations of the field to predict the permeability, allowing for extension of flow units to these wells using statistical methods.

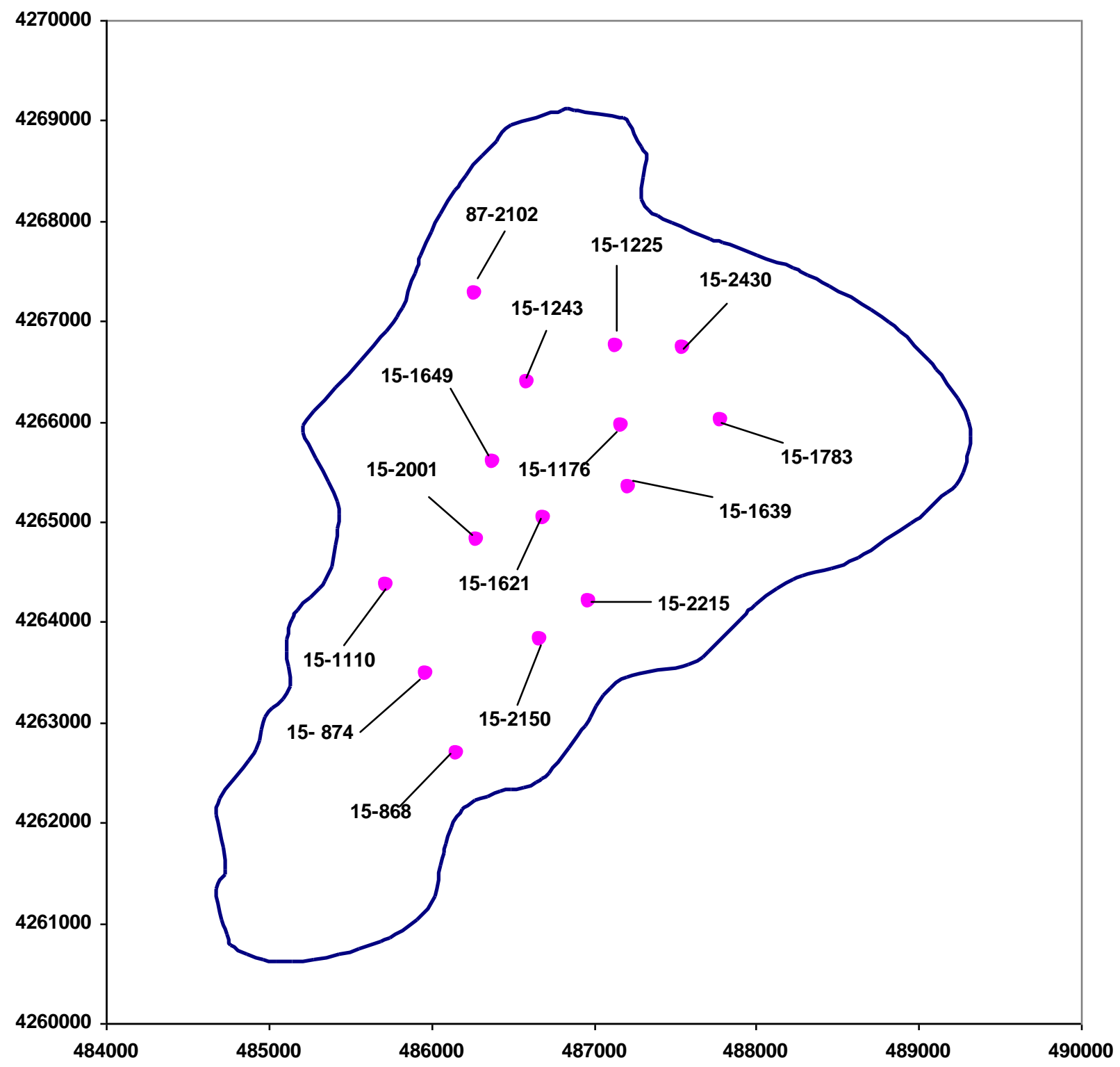

Figure 3.3: L ocation of Fifteen W ells without cores in the Granny C reek Field 


\subsection{Development of Permeability prediction model:}

Obtaining permeability data through core analysis is expensive and time consuming. Although permeability plays an important role to characterize a reservoir, it is not available for all wells in a reservoir. In this study a model is developed to predict permeability at definite depths of wells from the known permeability of other wells. The objective of this research is to develop a model which is computationally simple, easy and less expensive.

In lieu of a definite mathematical relationship of permeability with any measured parameter of the wells, this research aimed at developing a statistical model. Preliminary observation suggested that a linear regression model might be a simple but accurate

enough solution. A regression model is a formal means of expressing the two essential ingredients of a statistical relation:

1. A tendency of the dependent variable $\mathrm{Y}$ to vary with the independent variable or variables in a systematic fashion.

2. A scattering of observations around the curve of statistical relationship. These two characteristics are embodied in a regression model by postulating that:

1. In the population of observations associated with the sampled process, there is a probability distribution of $\mathrm{Y}$ for each level of $\mathrm{X}$.

2. The means of these probability distributions vary in some systematic fashion with $\mathrm{X}$. 


\subsubsection{Selection of Independent V ariable:}

Since data must be reduced to manageable proportions whenever we contrast models, only a limited number of independent or predictor variables can - or should - be included in a regression model for any situation of interest. A central problem therefore is that of choosing, for a regression model, a set of independent variables which is "good" in some sense for the purposes of analysis. A major consideration in making this choice is the extent to which a chosen variable contributes to reducing the remaining variation in $\mathrm{Y}$ after allowance is made for the contributions of other independent variables that have tentatively been included in the regression model. Other considerations include the importance of the variable as a casual agent in the process under analysis; the degree to which observations on variable can be obtained more accurately, or quickly, or economically than on competing variables; and the degree to which the variable can be

preset by management. Predictor variable must be readily available and have sufficient causal effect on the predicted variable. In the literature review it has been observed that bulk density has an impact on reservoir permeability. Density log, gamma ray and some other data are also readily available. Hence, density log data is used as an independent variable in this model.

\subsubsection{F unctional Form of M odel $^{17}$ :}

Density is the most influential factor in determining permeability, but exact form of the relationship is unknown. To get the relationship between density and permeability we tried the following approach

1) Permeability versus density linear plot. 
2) Direct approach: changes the model according to the nature of the relationship. For example, a quadratic or polynomial relationship may be tried.

3) Transformation approach: uses transformation to linearize.

Among the above three approaches a better linear relationship or correlation is found between density (D) and logarithmic transformation of permeability (K). The transformation used is $\mathrm{Y}=\log \mathrm{K}$. The plot of transformed values for measured data from well 15-1184 is presented in Figure 3.4. The plots of transformed values for the remaining core wells are shown in Appendix B.

The general form of the proposed prediction model is:

$$
\log K=\gamma_{0}+\gamma_{1} D
$$

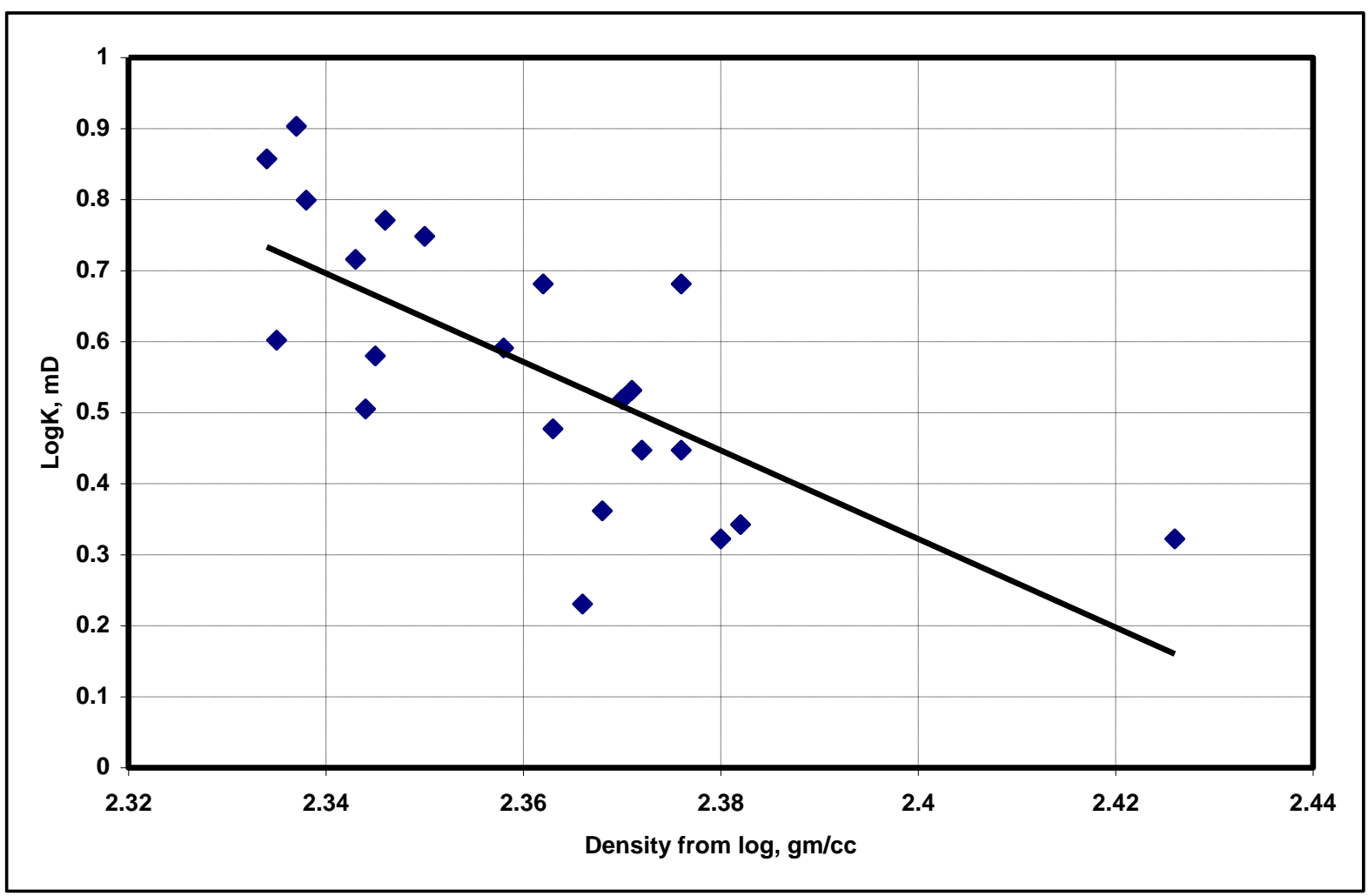

Figure 3.4: Plot of Density versus Log K data taken from well 15-1184. 


\subsubsection{Assumptions:}

1) In model development, it is assumed that the average of the measured permeability over a small distance is a reliable representation of the permeability at the mid-point of that measured distance.

2) The model is only valid for the reservoir from which development data set is obtained.

3) The model assumes that reasonable number of permeability data is available for adjacent wells at various depths.

\subsubsection{V alidation of M odel:}

The density from the $\log$ and core permeability data from ten wells were available. The density from the log for each of those ten wells was measured for every $1 / 4$ feet interval. Table 3.1 below shows the number of permeability data available for ten wells used in this study.

\begin{tabular}{|c|c|c|c|}
\hline $\begin{array}{l}\text { Number of } \\
\text { Well data } \\
\text { set }\end{array}$ & $\begin{array}{l}\text { Well } \\
\text { name }\end{array}$ & $\begin{array}{l}\text { Depth interval, } \\
\mathrm{ft}\end{array}$ & $\begin{array}{l}\text { Original No. of } \\
\text { permeability } \\
\text { data }\end{array}$ \\
\hline 1 & $15-733$ & 2085-2097 & 9 \\
\hline 2 & $15-1059$ & $2028-2031.5$ & 4 \\
\hline 3 & $15-1107$ & $2140-2157.1$ & 7 \\
\hline 4 & $15-1108$ & $2064.5-2093$ & 19 \\
\hline 5 & $15-1109$ & 1915.1-1927.5 & 6 \\
\hline 6 & $15-1128$ & $2027.2-2038.6$ & 9 \\
\hline 7 & $15-1130$ & $1885.3-1903.9$ & 15 \\
\hline 8 & $15-1132$ & $1993.5-2012.1$ & 14 \\
\hline 9 & $15-1184$ & $1872.5-1897.5$ & 25 \\
\hline 10 & $15-1309$ & 1961-1982 & 16 \\
\hline
\end{tabular}

Table 3.1: Number of available core permeability data for ten cored wells 
For this data set ten different tests were performed to validate the proposed linear transformation model. In each test, the above data set is divided into two different sets. Set1 consists of measured data from 9 wells, which is used to develop the regression model parameters. The regression equation is then used to predict and compare the permeability of the remaining well, which is in set 2 . Table 3.2 below shows the description of ten different tests:

\begin{tabular}{|c|c|c|}
\hline Test Number & Development Data Set & Validation D ata Set \\
\hline Test-1 & $2,3,4,5,6,7,8,9,10$ & 1 \\
\hline Test-2 & $1,3,4,5,6,7,8,9,10$ & 2 \\
\hline Test-3 & $1,2,4,5,6,7,8,9,10$ & 3 \\
\hline Test-4 & $1,2,3,5,6,7,8,9,10$ & 4 \\
\hline Test-5 & $1,2,3,4,6,7,8,9,10$ & 5 \\
\hline Test-6 & $1,2,3,4,5,7,8,9,10$ & 6 \\
\hline Test-7 & $1,2,3,4,5,6,8,9,10$ & 7 \\
\hline Test-8 & $1,2,3,4,5,6,7,9,10$ & 8 \\
\hline Test-9 & $1,2,3,4,5,6,7,8,10$ & 9 \\
\hline Test-10 & $1,2,3,4,5,6,7,8,9$ & 10 \\
\hline
\end{tabular}

Table 3.2: $L$ ists of ten different tests performed.

The predicted permeability values are compared against the measured permeability values and the results are shown in Appendix B.

\subsubsection{Development of Permeability prediction model for uncored wells:}

The density from the log and core permeability data available from ten core wells are used to develop a linear relationship or correlation between density (D) and logarithmic transformation of permeability $(\mathrm{K})$. The transformation used is $\mathrm{Y}=\log \mathrm{K}$. The plot of 
transformed values for measured data is presented in Figure 3.5 and the proposed prediction model for uncored wells is:

$$
\log \mathrm{K}=15.649-6.3461 * \mathrm{D}
$$

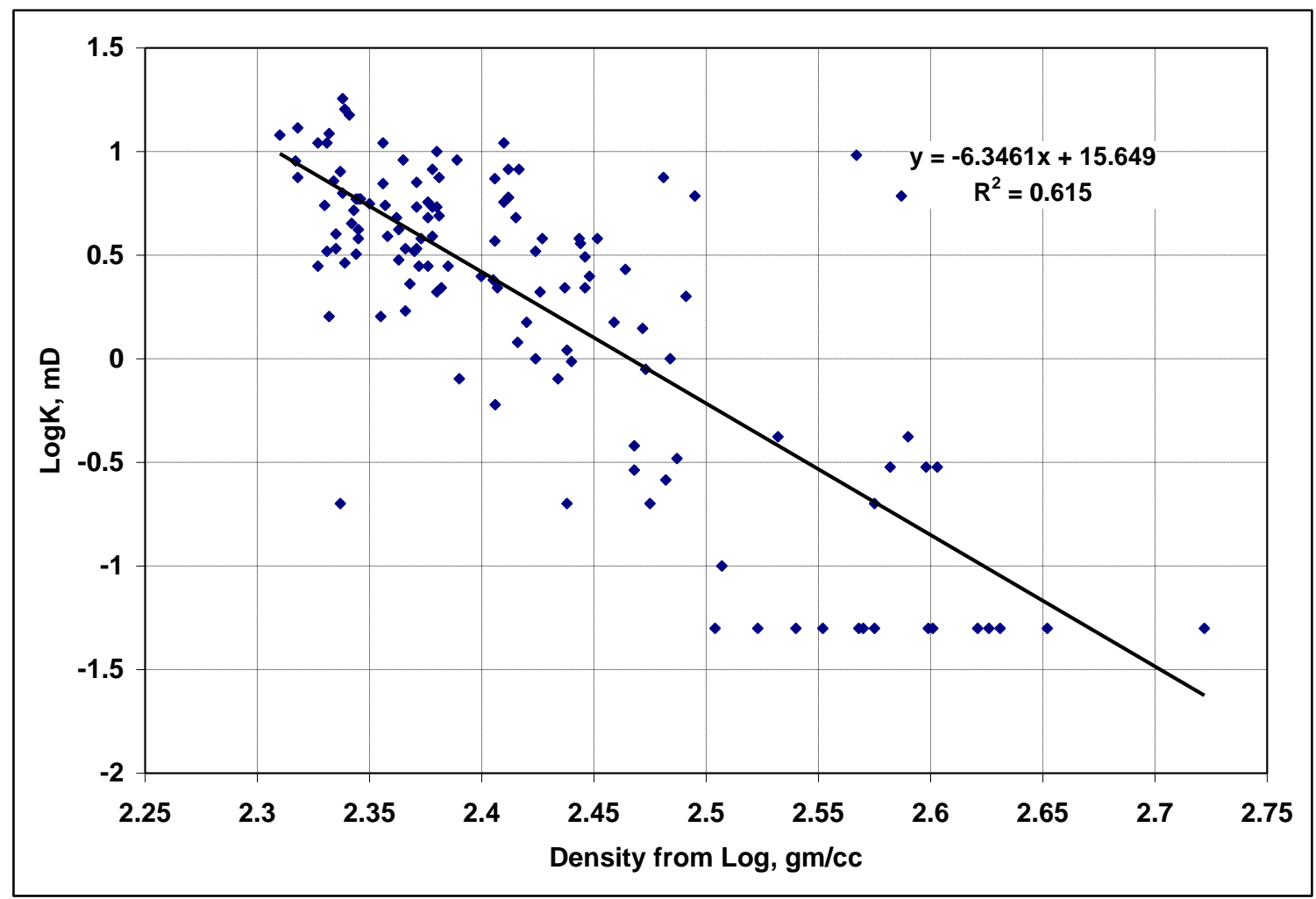

Figure 3.5: Plot of Density versus L og K data taken from ten core wells.

\subsection{Determination of F low Units for individual wells:}

The different mathematical and statistical techniques discussed in Chapter 2 can be used in the determination of flow units. In this study, the statistical zonation technique is used to determine the flow units from measured core permeability and predicted permeability.

In the computational procedure, core permeability data measured at different depths from Set 1(well 15-733) has been selected randomly. Table C-1 in Appendix C illustrates the calculation for well 15-733. Initially the cumulative sum of the permeability is calculated 
followed by the difference of the grand sum minus cumulative sum of K. Later Equations 9, 10 and 11 are used to calculate $\mathrm{B}, \mathrm{W}, \mathrm{R}$ and the results are tabulated. In this calculation, the negative $\mathrm{R}$ values are replaced by zero according to the definition of $\mathrm{R}$. For example, the first B, W, R values in Table C-1 are calculated as follows.

\section{Variance between zones:}

$$
\begin{aligned}
& \text { B } \frac{1}{\mathrm{~L} 1} \mathrm{i}_{\mathrm{i} 1}\left(\overline{\mathrm{k}}_{\mathrm{i}} \overline{\mathrm{k}}_{. .}\right)^{2} \\
& =16.965
\end{aligned}
$$

\section{Variance within zones:}

$$
\begin{aligned}
& W{ }^{W}{ }^{N}{ }_{i 1}^{m_{i} m_{i}}\left(\bar{k}_{i} \bar{k}_{. .}\right)^{2} \\
& =0.928
\end{aligned}
$$

\section{The zonation index:}

$$
\begin{aligned}
& R \frac{B W}{B} \\
& =0.9453
\end{aligned}
$$

Similarly the other values in the Table $\mathrm{C}-1$ are calculated. The best division into two zones occurs after the permeability of $2.7 \mathrm{mD}$ at $2087.5 \mathrm{ft}$ since this depth yields the maximum zonation index R. The asterisk marks are the point of division into two zones in Table C-1. 
In order to determine if more zones exist, the calculations of $\mathrm{B}, \mathrm{W}, \mathrm{R}$ are repeated and the the results are tabulated in Table C-2. The second point of division (the first was after the permeability value of $2.7 \mathrm{mD}$ in Table C-1) occurs after the permeability value of $4.9 \mathrm{mD}$ at $2085.5 \mathrm{ft}$ in Group 1 data series and divides our total data into three zones. It has been observed that the maximum zonation index $\mathrm{R}(0.8603)$, in Group 2 data is less than the initial zonation index R (0.9463) used for dividing into two zones. Hence Group 2 data cannot be divided further into any more zones. Therefore, we can conclude that there are three different flow units in the well 15-733.

Similarly all the other wells were divided into flow units using measured core permeability and predicted permeability data and the final results are tabulated in Appendix C and D respectively. Same approach is used for the predicted permeability values from selected wells without cores to identify the flow units and the results are tabulated in Appendix E.

\subsection{C or relation of flow units between wells:}

After all zones are determined for each well used in this study, the second portion of the calculation is undertaken. This part correlates the zones throughout the reservoir to aid the engineer in determining the continuity of the strata. The correlation is based on a statistical comparison of the difference of means of two zones in adjoining wells with the difference that could be expected from variation of measurements within zones. If the difference of means is less than or equal to that expected from individual data variation, 
the zones represented by the means are considered to correlate and, by inference, be continuous.

The mathematical statement is given by Equation 12:

$$
\left(\begin{array}{ll}
\bar{k}_{h} & \overline{k_{i}}
\end{array}\right) \quad \sqrt{\frac{1}{2}\left(\frac{1}{n_{h}} \frac{1}{n_{i}}\right)} S Z_{(v, p)}
$$

Harter ${ }^{18}$ provides a table of Z- values.

If the left side of Equation 12 is larger than the right side, the zones represented by the two means are considered, on the basis of statistics, to be different. However, if the left side of Equation 12 is smaller than the right side, the zones correlate and considered to be continuous.

From the Tables in Appendix C, D and E, Equation 12 has been applied to the zone data for flow unit correlation between wells. The calculations for flow unit correlation between wells are presented in Appendix F for original flow units from ten cored wells and for predicted flow units from fifteen wells without cores. The following steps are suggested as a conventional and efficient manner to apply Equation 12:

(1) Rank well-zone means in the order of decreasing magnitude of permeability, as shown in Table F.1.

(2) Calculate variance with Equation 10 using all permeability data in the entire reservoir.

(3) Calculate the standard deviation from Step 2.

(4) Select the z-values for a $99 \%$ probability level $\left(\mathrm{Z}_{\mathrm{v}, \mathrm{p}}\right)$ 
(5).Multiply the z-values in Step 4 by the standard deviation in Step 3, e. $g ., F \nsupseteq p=S z_{v, p}$

(6). Test the significant differences among well - flow unit means. First the largest mean is compared with each of the smaller means.

Finally the means can be divided into separate groups, which are not significantly different. 


\section{CHAPTER 4}

\section{RESULTS AND DISCUSSIONS}

In this study a predictive model is developed for flow unit correlation based on well log and core data. The model is validated with the data available from Granny Creek Field, WV. The density from the $\log$ and core permeability data was available for ten core wells. The model is validated several times by dividing the available data into two sets: Set I: development data set containing data from nine wells and Set II: the validation data set which consist the data from the remaining well. The resulting ten tests are described in Table 3.2. Apart from the model discussed above a second model is developed utilizing the density from the $\log$ and core permeability data of all ten core wells to predict the permeability for wells without cores, allowing for extension of flow units to these wells. In this chapter, the predicted flow strata for wells without cores and flow strata from measured data are presented and analyzed.

\subsection{Discussion of results from T est 1:}

In the first test case, data set is divided into the following two sets:

Set I: Development data set: Includes wells 15-1059, 15-1107, 15-1108, 15-1109, 15$1128,15-1130,15-1132,15-1184,15-1309$.

Set II: Validation Data Set: Consists of well 15-733.

Based on the measured data for the wells in Set I, the linear model for permeability prediction is developed. The linear relationship of logarithm of permeability and density from the $\log$ is developed as discussed in Section 3.3.2. The model is given by: 


\section{$\log K=14.332-5.7905 X$}

Where $\mathrm{X}$ is the density from the log of the well.

Based on this model, the permeability for the well 15-733 in Set II is predicted. Figure 4.1.1 compares the predicted permeability and measured core permeability at different depths of the well. Using this predicted permeability and the method described in Section 3.4, flow units for the well 15-733 are computed. The predicted flow units are compared with the flow units obtained by using measured permeability based on data Set II. Figure 4.1.1 shows that the predicted permeability and measured permeability values at different depths of the well are pretty much in agreement.

Figure 4.1.2 shows that the well has three statistically significant flow zones based on measured permeabilities whereas two statistically significant flow zones were identified with the predicted permeability values. The incompleteness in the actual data and their irrelevancies due to very low permeability values tend to reduce the correlation between core permeability and density from the log. The flow unit computations based on the few predicted data have forced the well into two statistically significant flow zones. Figure 4.1.2 shows that the predicted mean permeability values are different from the actual mean values, but it is clear that the high permeability zone intervals are identical. In general, the model closely predicts the high permeability and low permeability zones for the well 15-733. 


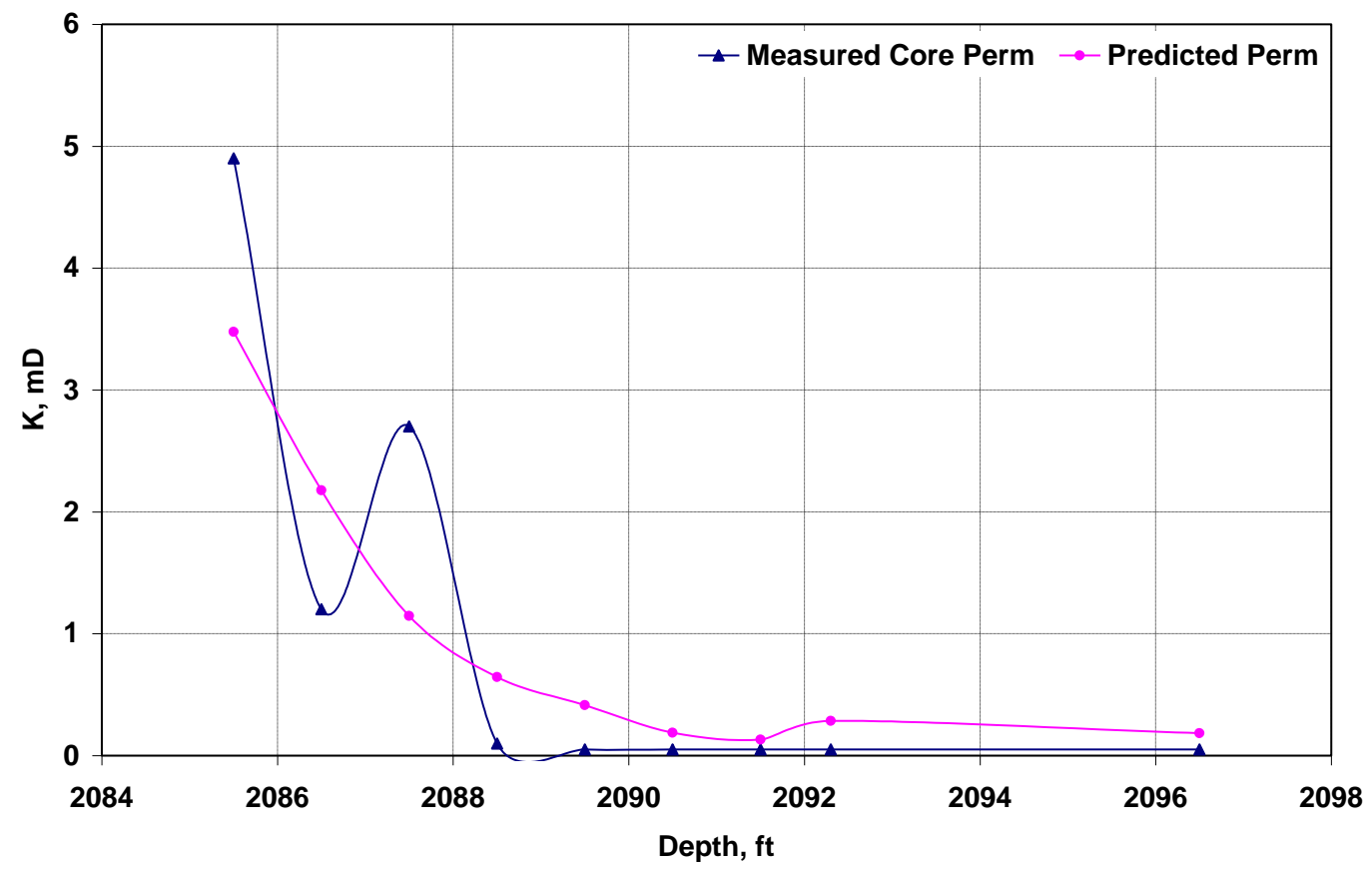

Figure 4.1.1 Comparison of M easured and Predicted permeability values for well 15-733.

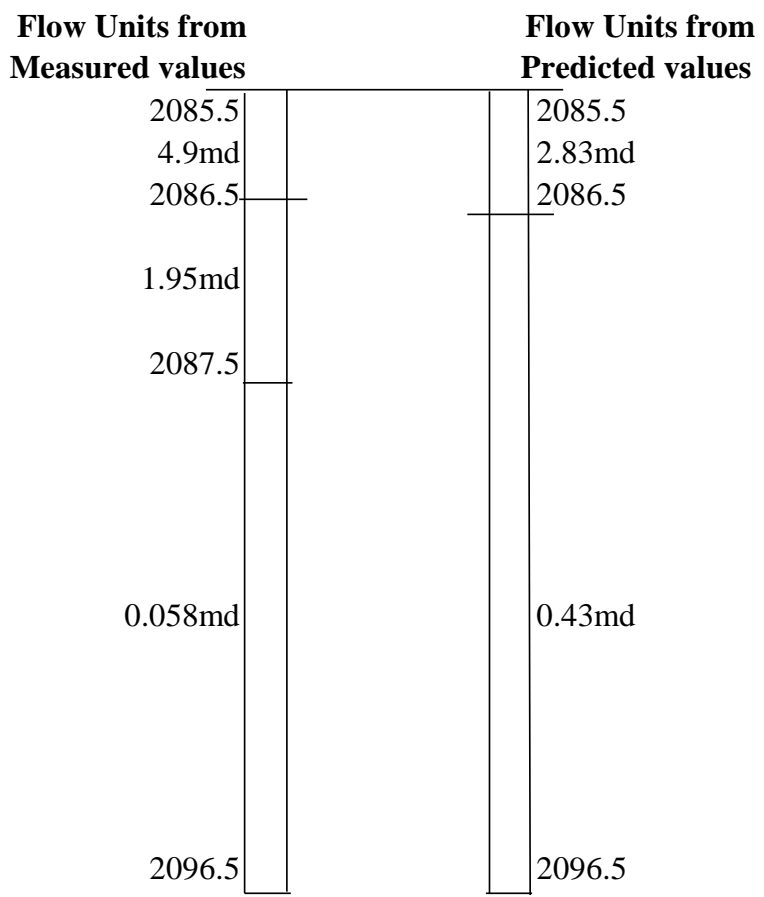

Figure 4.1.2 C omparison of flow units for well 15-733 based on mean permeability from measured and predicted values. 


\subsection{Discussion of results from Test 2:}

In the second test, data set is divided into following two sets:

Set I: Development data set with permeability values from wells 15-733, 15-1107, 151108, 15-1109, 15-1128, 15-1130, 15-1132, 15-1184, 15-1309.

Set II: Validation Data Set with permeability values from well 15-1059.

The permeability prediction model is given by:

\section{$\log K=16.378-6.6515 X$}

Where $\mathrm{X}$ is the density from the log of the well.

Figure 4.2.1 shows the comparison of the predicted permeability and measured core permeability values at different depths for well 15-1059. Using this predicted permeability and the technique described in Section 3.4 flow units for the well 15-1059 are computed. The predicted flow units are compared with the flow units obtained by using measured permeability (data Set II) in Figure 4.2.2.

Figure 4.2.1 shows that the predicted permeability and measured permeability at different depths of the well are in good agreement. Figure 4.2.2 shows that the original flow unit and the predicted flow unit has divided the well into single flow zone. The flow unit computations based on the few predicted data have forced the well into single statistically significant flow zones. 


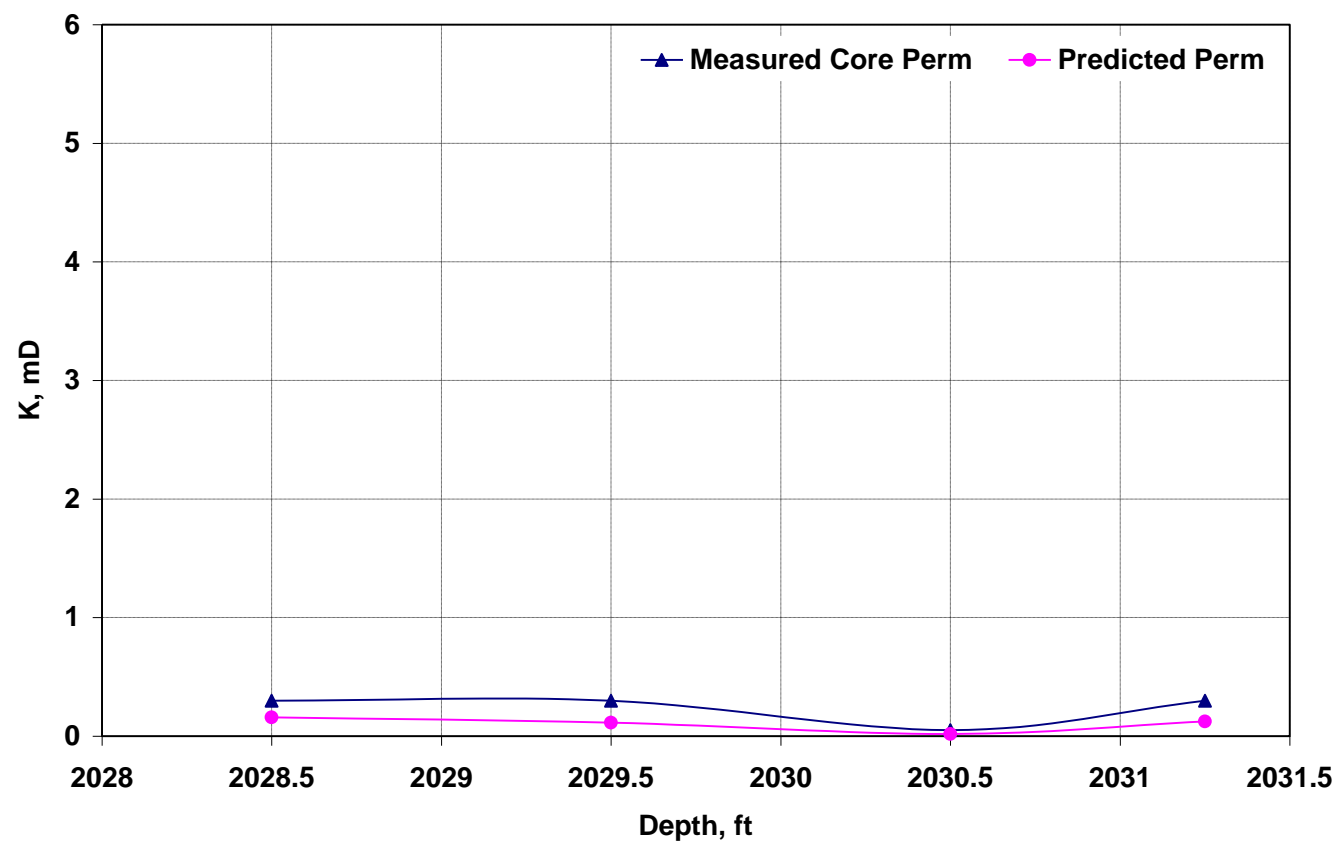

Figure 4.2.1 Comparison of M easured and Predicted permeability values for well 15-1059.

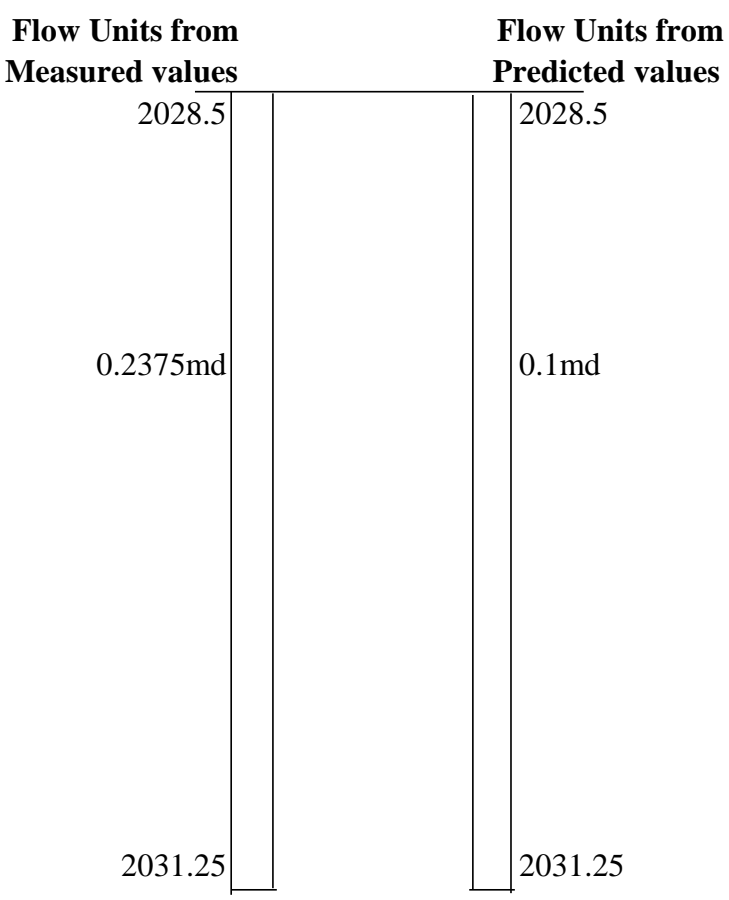

Figure 4.2.2 Comparison of flow units for well 15-1059 based on mean permeability from measured and predicted values. 


\subsection{Discussion of results from Test 3:}

The third set consisted of the data divided into following two sets:

Set I: Development data set with permeability values from wells 15-733, 15-1059, 151108, 15-1109, 15-1128, 15-1130, 15-1132, 15-1184, 15-1309.

Set II: Validation Data Set with permeability values from the well 15-1107.

The permeability prediction model is given by:

\section{$\log K=15.382-6.2278 X$,}

Where $\mathrm{X}$ is the density from the log of the well.

Figure 4.3.1 compares the predicted permeability and measured core permeability at different depths of the well. The predicted flow units are compared with the flow units obtained by using measured permeability in data Set II as shown in Figure 4.3.2.

Figure 4.3.1 shows that the predicted permeability and measured permeability values at different depths of the well are pretty much in agreement. However, the predicted values don $\square$ t show the variation of permeability as observed in core measurements. Figure 4.3.2 shows that the predicted model divides the well into four flow zones whereas the original data shows that the well has three zones. The incompleteness in the actual data and the difficulty in predicting very low permeability values tend to reduce the correlation between core permeability and density from the log. Though the Figure 4.3.2 shows that the predicted mean permeability values deviate from the measured mean values, it is clear that the high permeability and low permeability zones have similar average permeability values. Thus the model closely predicts the high permeability and low permeability zones for the well 15-1107. 


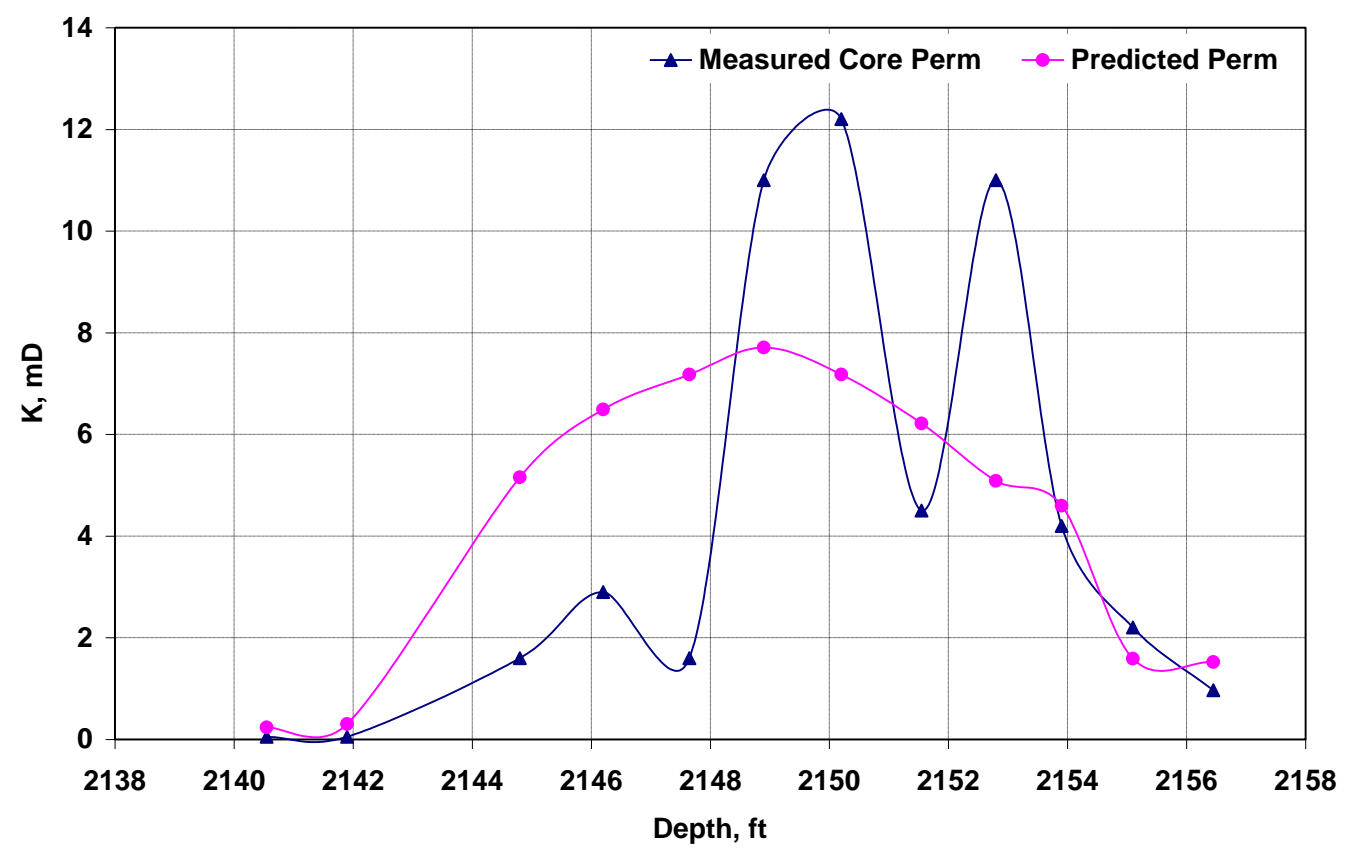

Figure 4.3.1 Comparison of M easured and Predicted permeability values for well 15-1107.

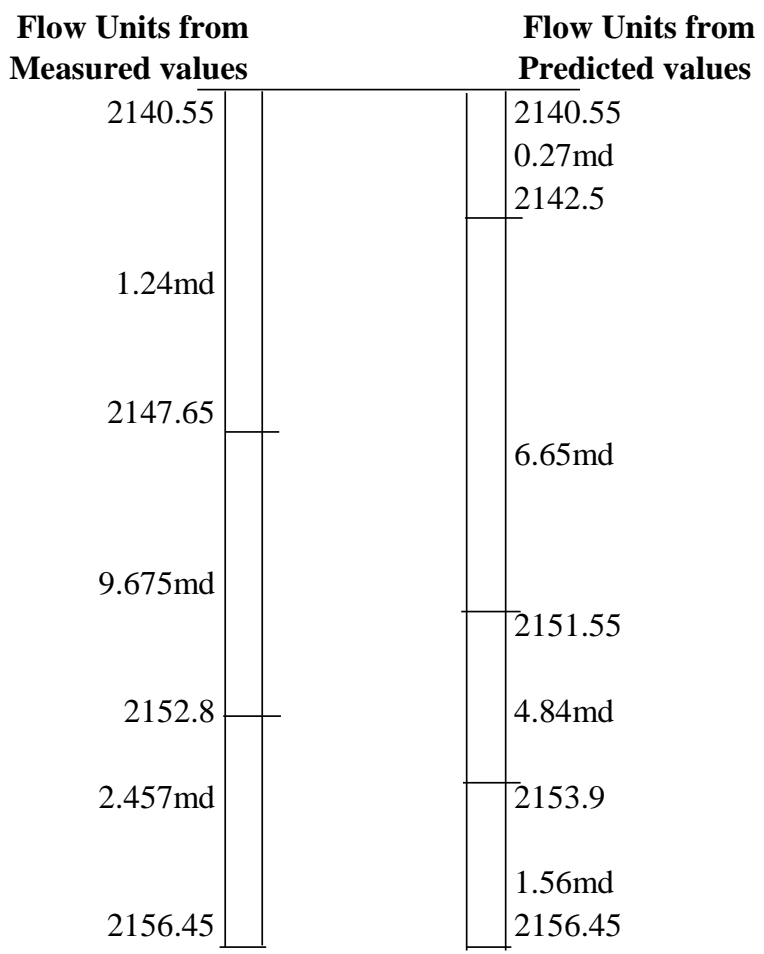

Figure 4.3.2 Comparison of flow units for well 15-1107 based on mean permeability from measured and predicted values. 


\subsection{Discussion of results from Test 4:}

In the fourth test, data set is divided into following two sets:

Set I: Development data set with permeability values from wells 15-733, 15-1059, 15$1107,15-1109,15-1128,15-1130,15-1132,15-1184,15-1309$.

Set II: Validation Data Set with permeability values from well 15-1108.

The permeability prediction model is given by:

\section{$\log K=16.925-6.8787 X$,}

Where $\mathrm{X}$ is the density from the log of the well.

The comparison of the predicted permeability and measured core permeability at different depths of the well are shown in Figure 4.4.1. The predicted flow units are compared with the flow units obtained by using measured permeability from data Set II are shown in Figure 4.4.2. Figure 4.4.1 shows that the predicted permeability and measured permeability at different depths of the well are in good agreement except at some depths.

The Figure 4.4.2 shows that the predicted model divides the well into four flow zones same as the original permeability data. Though the predicted mean permeability values show some deviation from the original mean permeability values but it is clear that the high permeability and low permeability zone yield similar results. Again, the model was successful in predicting the high permeability and low permeability zones for the well 15 1108. 


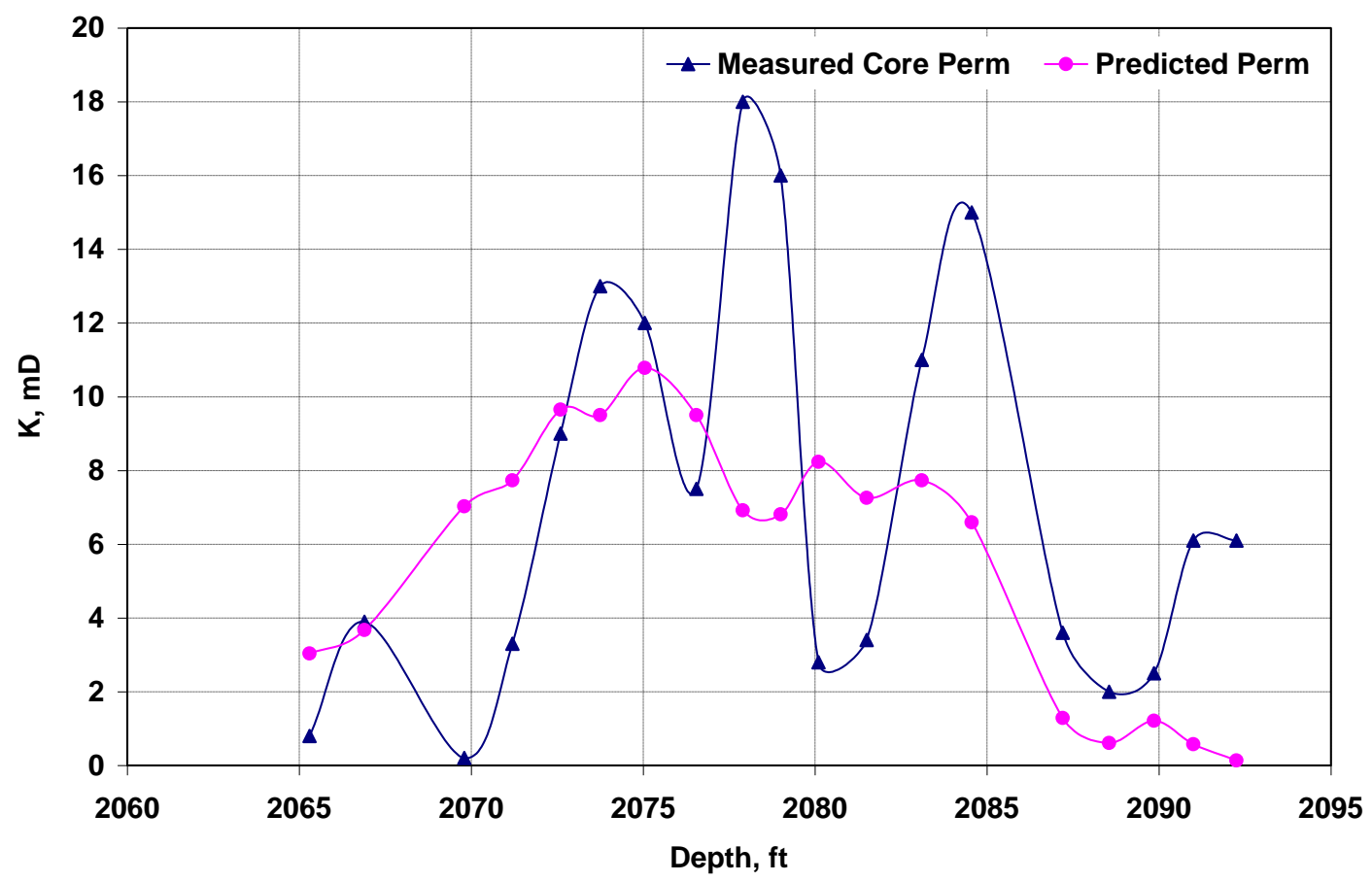

Figure 4.4.1 Comparison of M easured and Predicted permeability values for well 15-1108.

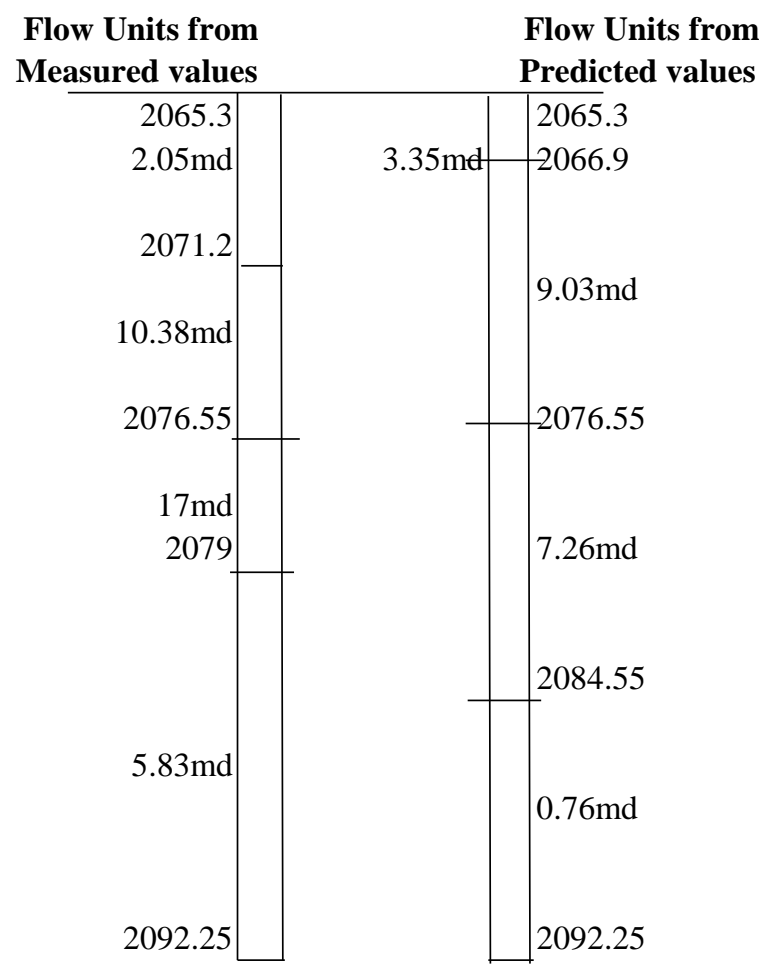

Figure 4.4.2 C omparison of flow units for well 15-1108 based on mean permeability from measured and predicted values. 


\subsection{Discussion of results from Test 5:}

In the fifth test, data set is divided into following two sets:

Set I: Development data set with permeability values from wells 15-733, 15-1059, 15$1107,15-1108,15-1128,15-1130,15-1132,15-1184,15-1309$.

Set II: Validation Data Set with permeability values from well 15-1109.

The permeability prediction model is given by:

\section{$\log K=14.934-6.0382 X$,}

where $\mathrm{X}$ is the density from the log of the well.

Figure 4.5.1 presents the comparison of the predicted permeability and measured core permeability at different depths of the well. The predicted flow units are compared with the flow units obtained by using measured permeability from data Set II and the results are shown in Figure 4.5.2. Figure 4.5.1 shows that the predicted permeabilities are slightly higher than the measured permeabilities at initial depths of the well but, at deeper intervals of the well they are in good agreement.

The Figure 4.5.2 shows that the predicted model divides the well into two zones same as the prediction with the original permeability data. Though the predicted mean permeability values are off from the original mean permeability values, it is clear that the high permeability and low permeability zone predictions were the same. It can be noted that, for all practical purposes the zonal divisions at correct depth is much more significant than the absolute permeability values at certain depth. Hence, the model predicts the high permeability and low permeability zones within an acceptable accuracy for the well 15-1109. 


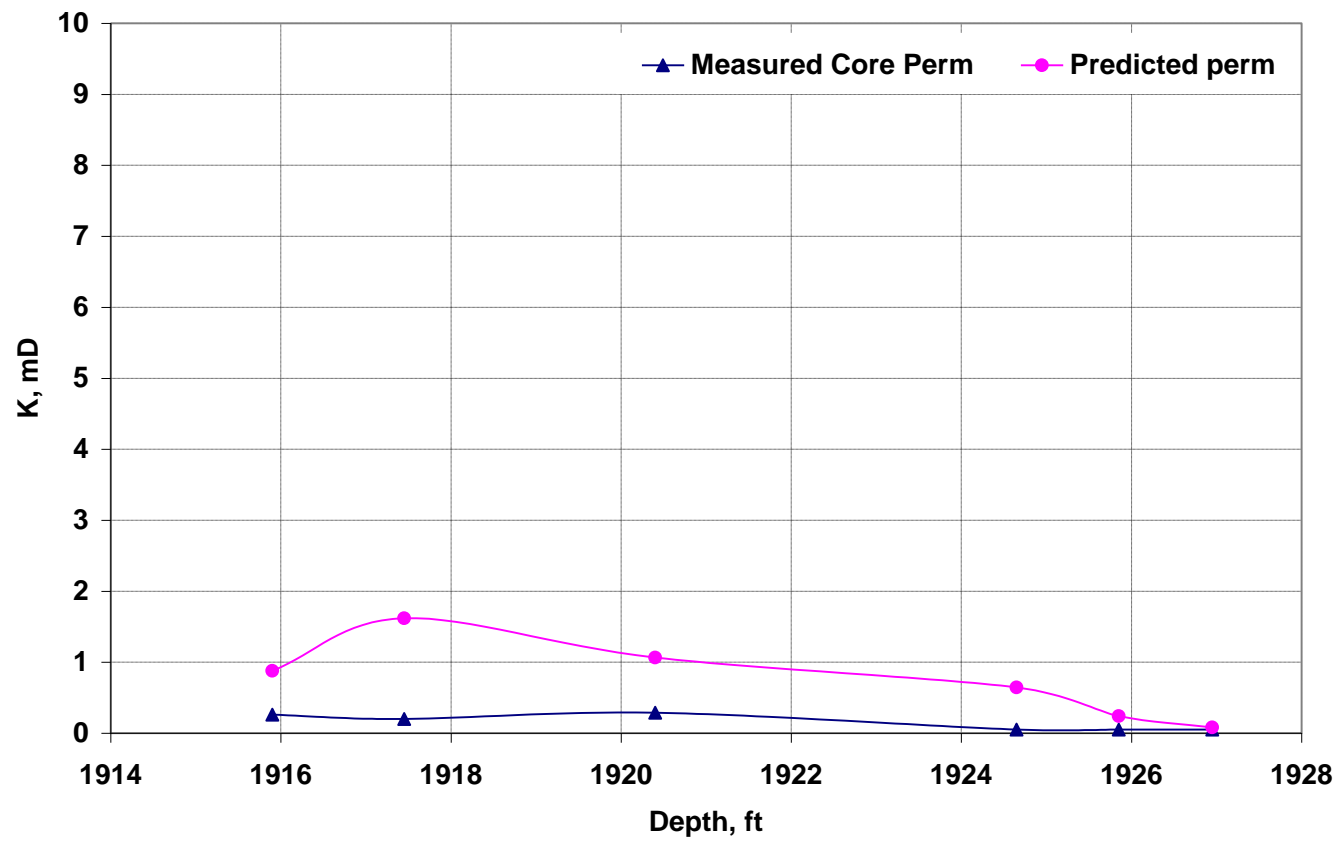

Figure 4.5.1 Comparison of M easured and Predicted permeability values for well 15-1109.

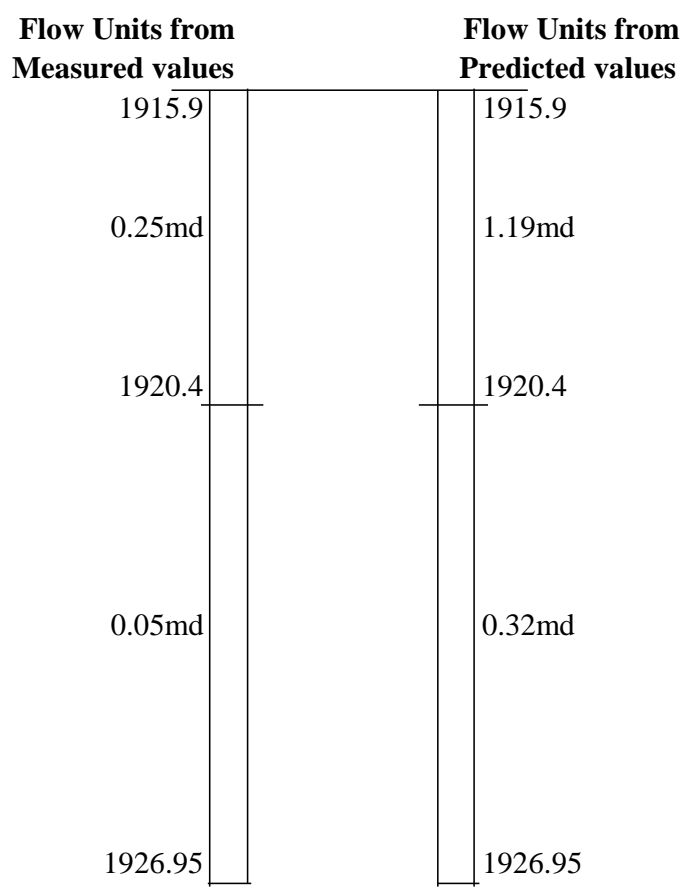

Figure 4.5.2 C omparison of flow units for well 15-1109 based on mean permeability from measured and predicted values. 


\subsection{Discussion of results from Test 6:}

In the sixth test data set is divided into following two sets:

Set I: Development data set with permeability values from wells 15-733, 15-1059, 15$1107,15-1108,15-1109,15-1130,15-1132,15-1184,15-1309$.

Set II: Validation Data Set with permeability values from well 15-1128.

The permeability prediction model is given by:

\section{$\log K=15.767-6.3953 X$}

where $\mathrm{X}$ is the density from the log of the well.

Figure 4.6.1 shows the comparison of the predicted permeability and measured core permeability at different depths of the well. The predicted flow units are compared with the flow units obtained by using measured permeability from data Set II and the results are shown in Figure 4.6.2.

Figure 4.6.1 shows that the predicted permeability and measured permeability at different depths of the well are in good agreement. Figure 4.6.2 shows that the predicted model divides the well into two zones whereas the original data shows that the well has three zones. The incompleteness in the actual data and the accuracy involved in the calculation of very low permeability values tend to reduce the correlation between core permeability and density from the log. The flow unit computations based on the few predicted data have forced the well into two statistically significant flow zones. Though the predicted mean permeability values deviate from the original mean permeability values it is clear that the high permeability and low permeability zone predictions are similar. In general, the zonal divisions at correct depth is much more significant than the absolute 
permeability values at certain depth and the model for well 15-1128 correctly predicts the high permeability and low permeability zones.

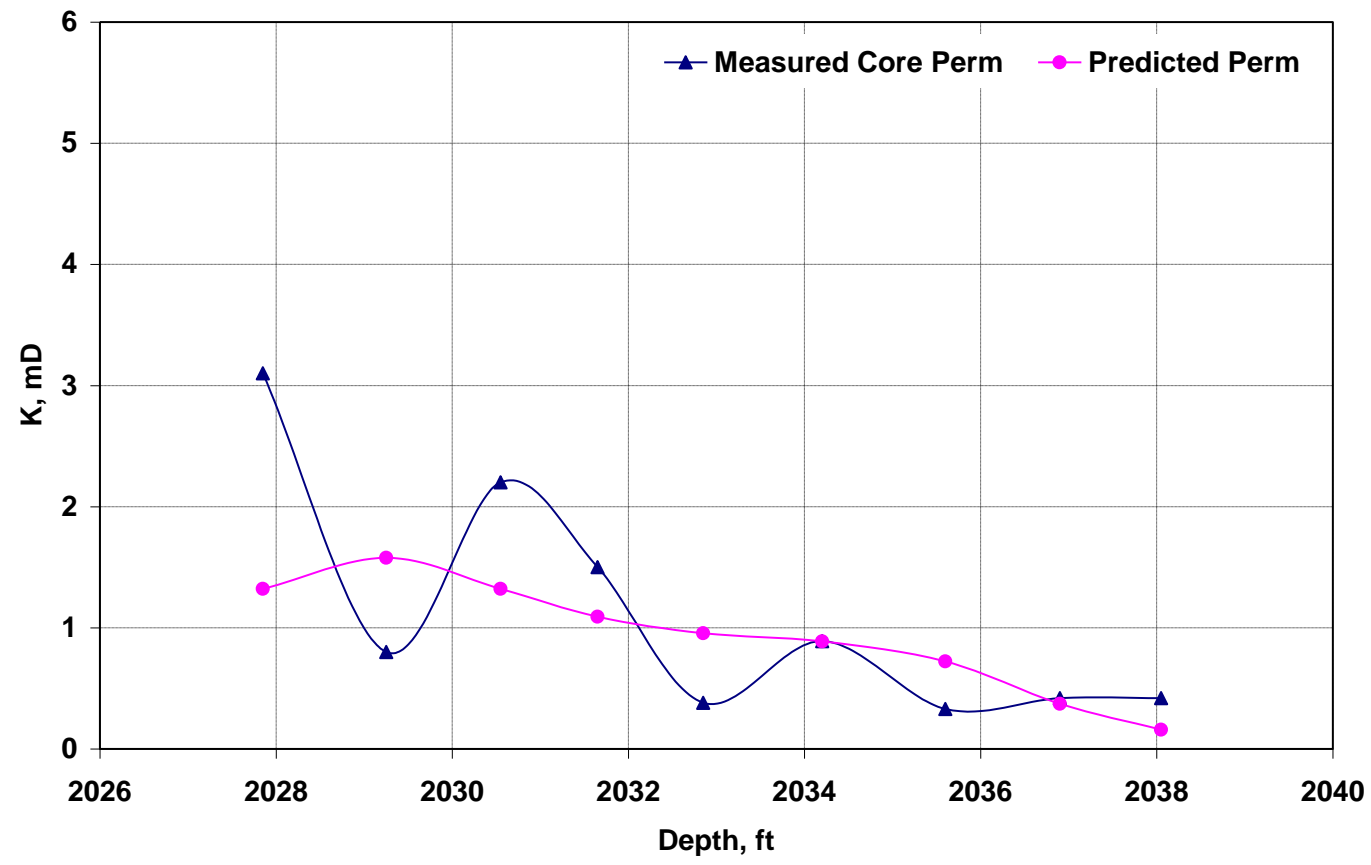

Figure 4.6.1 Comparison of M easured and Predicted permeability values for well 15-1128.

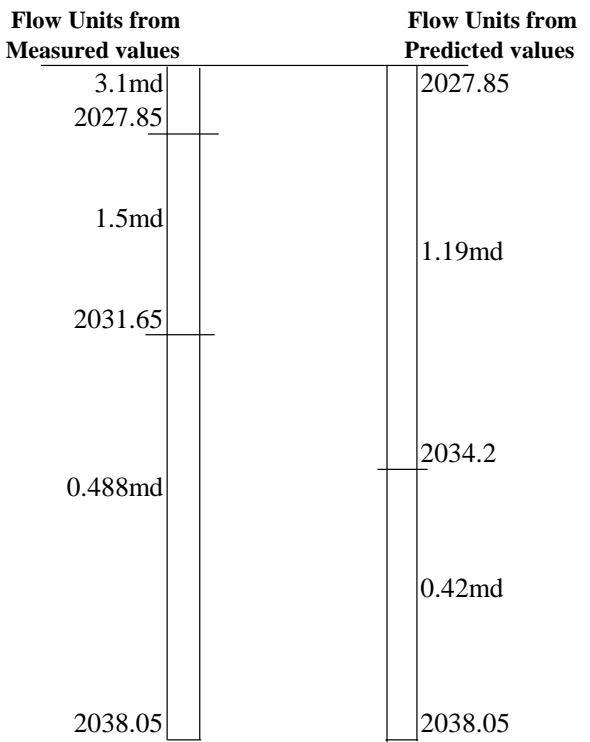

Figure 4.6.2 Comparison of flow units for well 15-1128 based on mean permeability from measured and predicted values. 


\subsection{Discussion of results from Test 7:}

In the seventh test, data set is divided into following two sets:

Set I: Development data set with permeability values from wells 15-733, 15-1059, 15$1107,15-1108,15-1109,15-1128,15-1132,15-1184,15-1309$.

Set II: Validation Data Set with permeability values from well 15-1130.

The permeability prediction model is given by:

\section{$\log K=15.546-6.3232 X$}

where $\mathrm{X}$ is the density from the log of the well.

Figure 4.7.1 shows the comparison of the predicted permeability and measured core permeability at different depths of the well. The predicted flow units are compared with the flow units obtained by using measured permeability from data Set II and the results are shown in Figure 4.7.2.

Figure 4.7.1 shows that the predicted permeabilities are low compared to the measured permeabilities at different depths of the well. However, the Figure 4.7.2 shows that the predicted model divides the well into two zones same as the original permeability data. Though the predicted mean permeability values deviate largely from the original mean permeability values, it is clear that the high permeability and low permeability zones are almost unaltered. It can be noted that, for all practical purposes the zonal divisions at correct depth is much more significant than the absolute permeability values at certain depth. Hence, it can be concluded that the model serves the purpose by predicting the high permeability and low permeability zones for the well 15-1130. 


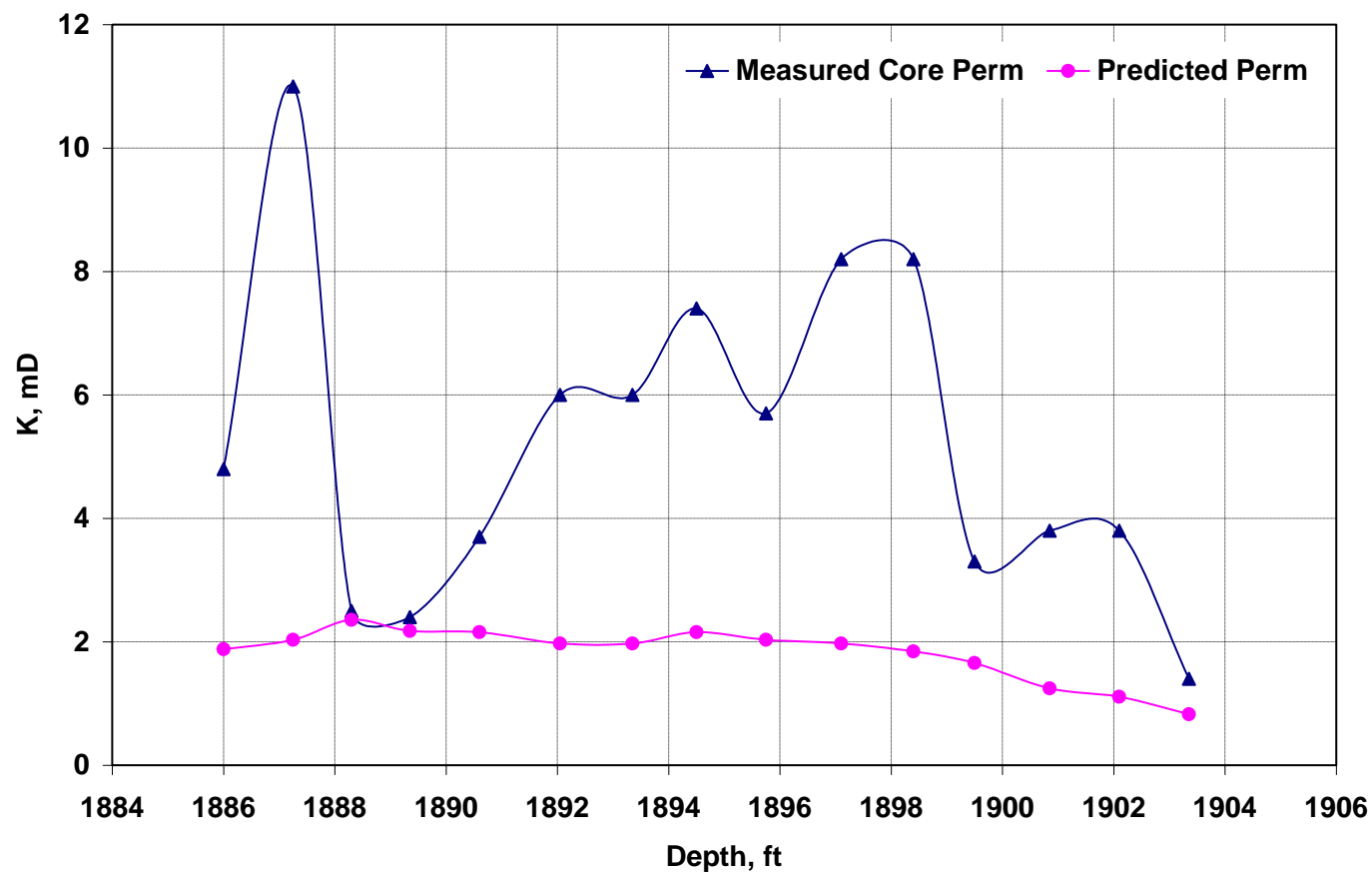

Figure 4.7.1 Comparison of $M$ easured and Predicted permeability values for well 15-1130.

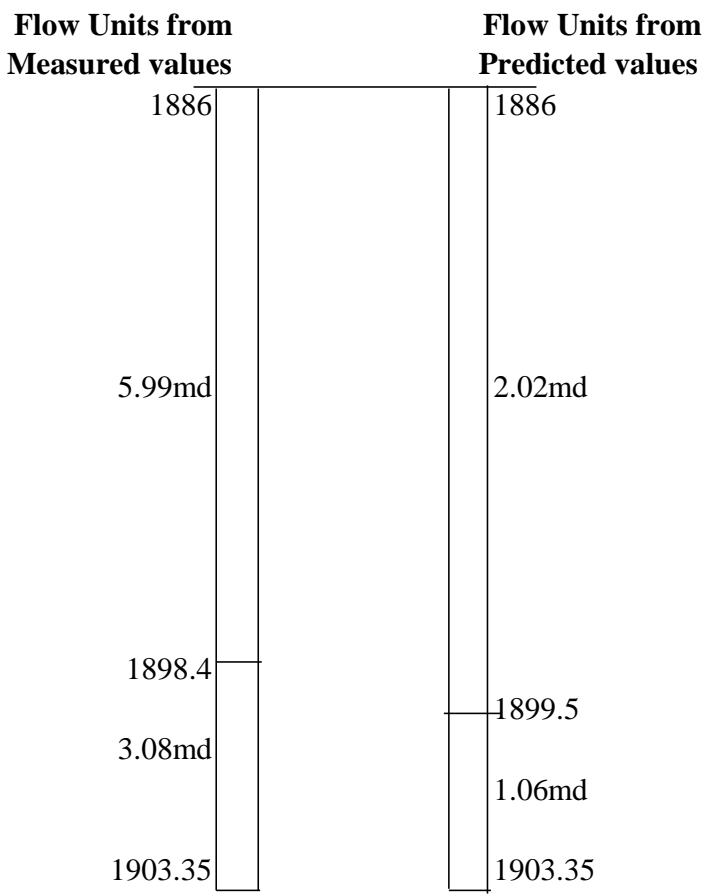

Figure 4.7.2 Comparison of flow units for well $15-1130$ based on mean permeability from measured and predicted values. 


\subsection{Discussion of results from Test 8:}

In the eighth test, data set is divided into following two sets:

Set I: Development data set with permeability values from wells 15-733, 15-1059, 15$1107,15-1108,15-1109,15-1128,15-1130,15-1184,15-1309$.

Set II: Validation Data Set with permeability values from well 15-1132.

The permeability prediction model is given by:

\section{$\log K=15.309-6.2094 X$}

where $\mathrm{X}$ is the density from the log of the well.

Figure 4.8.1 shows the comparison of the predicted permeability and measured core permeability at different depths of the well. The predicted flow units are compared with the flow units obtained by using measured permeability from data Set II and the results are shown in Figure 4.8.2. Figure 4.8.1 shows that the predicted permeabilities are low at initial depths compared to measured permeabilities but at deeper zones of the well they are pretty much in agreement.

The Figure 4.8.2 shows that the predicted model divides the well into two zones same as the original permeability data. Though the predicted mean permeability values deviate from the original mean permeability values, it is clear that the high permeability and low permeability zone predictions are similar. In general, the zonal divisions at correct depth is much more significant than the absolute permeability values at certain depth and the model for well 15-1132 correctly predicts the high permeability and low permeability zones. 


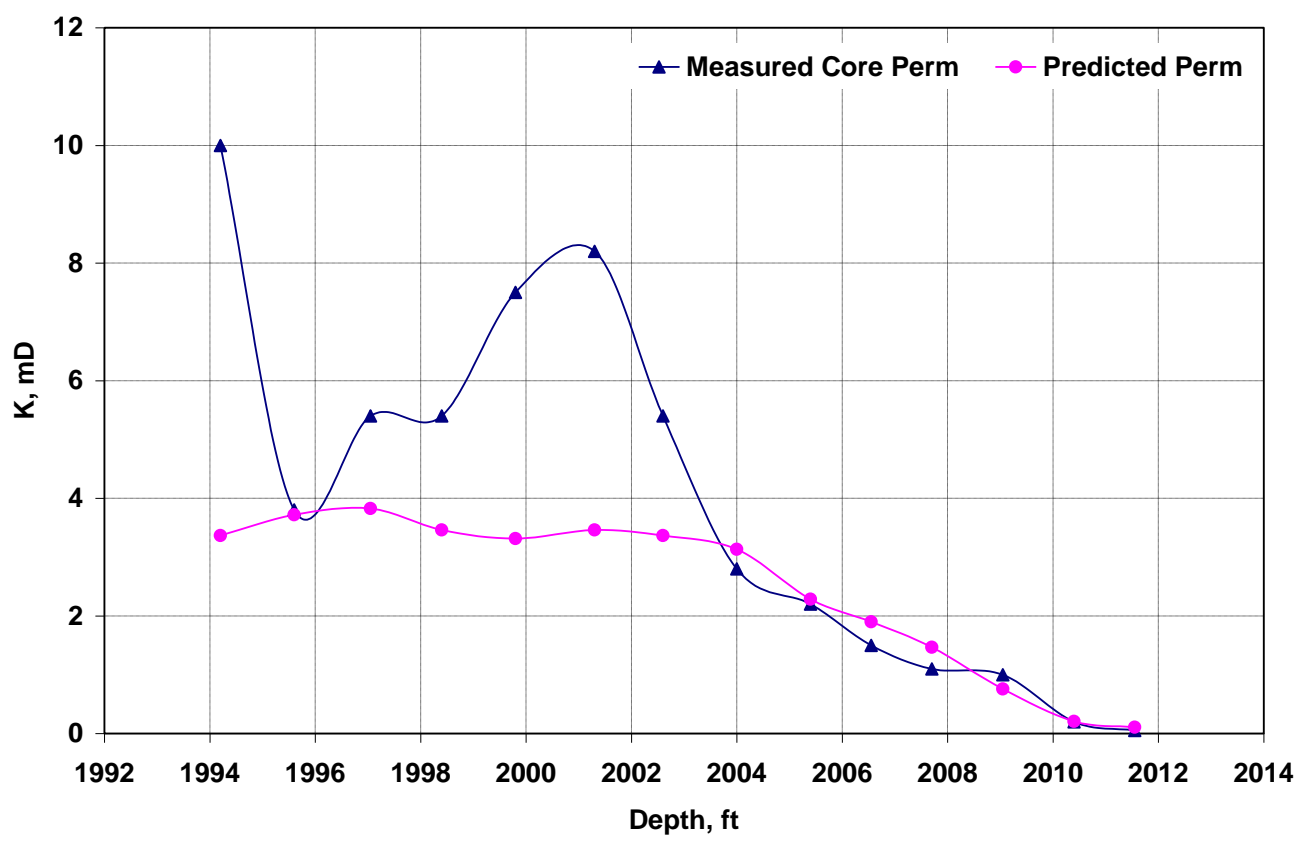

Figure 4.8.1 Comparison of $M$ easured and Predicted permeability values for well 15-1132.

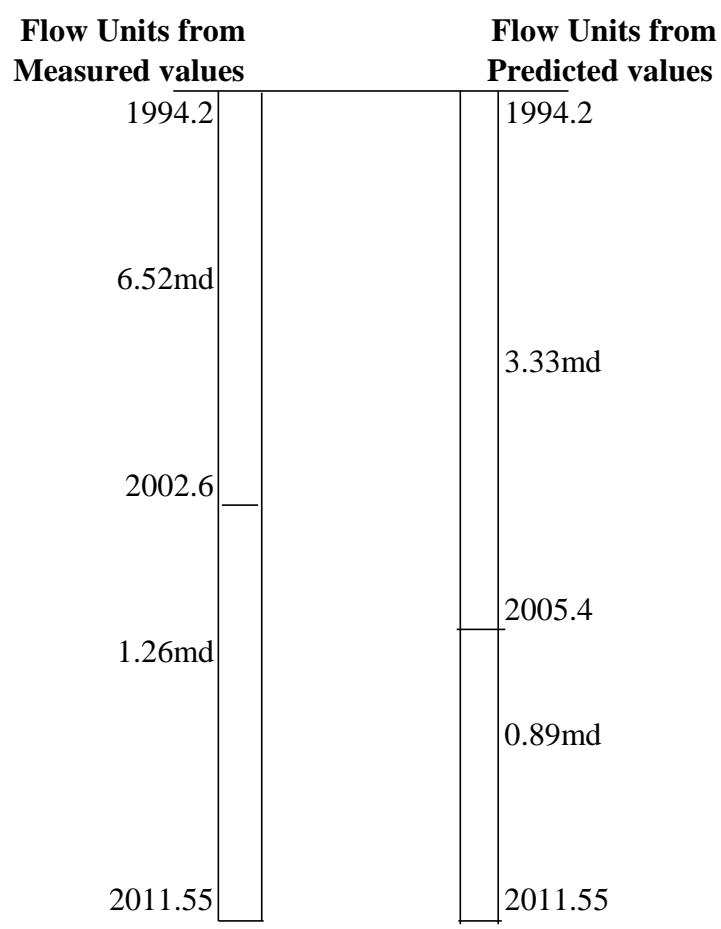

Figure 4.8.2 Comparison of flow units for well 15-1132 based on mean permeability from measured and predicted values. 


\subsection{Discussion of results from Test 9:}

In the ninth test, data set is divided into following two data sets:

Set I: Development data set with permeability values from wells 15-733, 15-1059, 15$1107,15-1108,15-1109,15-1128,15-1130,15-1132,15-1309$.

Set II: Validation Data Set with permeability values from well 15-1184.

The permeability prediction model is given by:

\section{$\log K=16.136-6.5309 X$}

where $\mathrm{X}$ is the density from the log of the well.

Figure 4.9.1 shows the comparison of the predicted permeability and measured core permeability at different depths of the well. The predicted flow units are compared with the flow units obtained by using measured permeability from data Set II and the results are shown in Figure 4.9.2. Figure 4.9.1 shows that the predicted permeabilities are slightly higher compared to measured permeabilities but at some depths of the well they are in good agreement.

The Figure 4.9.2 shows that the predicted model divides the well into two zones whereas the original data shows that the well has three zones. Though the predicted mean permeability values deviate from the original mean permeability values, it is clear that the high permeability and low permeability zone predictions are similar. In general, the zonal divisions at correct depth is much more significant than the absolute permeability values at certain depth and the model for well 15-1184 correctly predicts the high permeability and low permeability zones. 


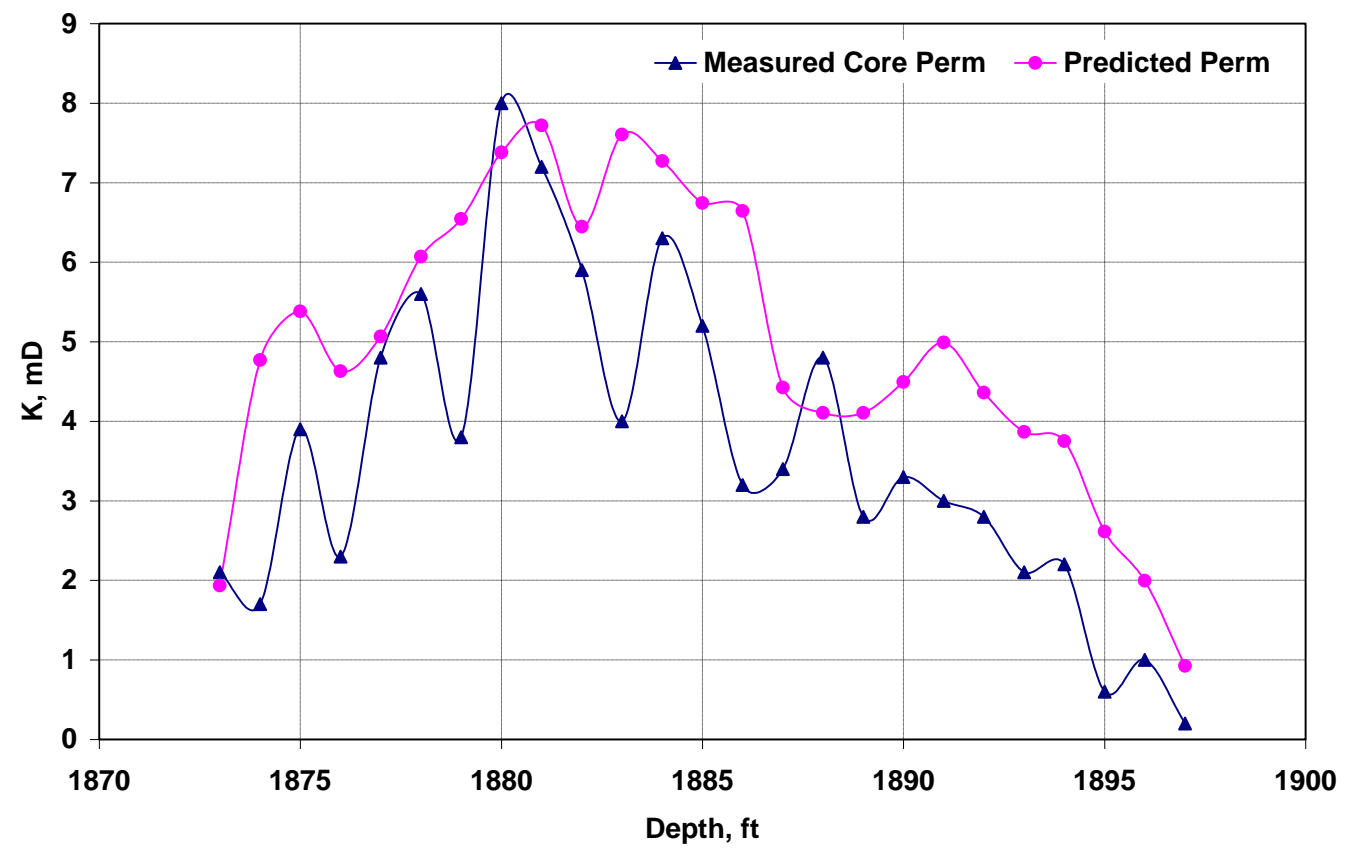

Figure 4.9.1 Comparison of M easured and Predicted permeability values for well 15-1184.

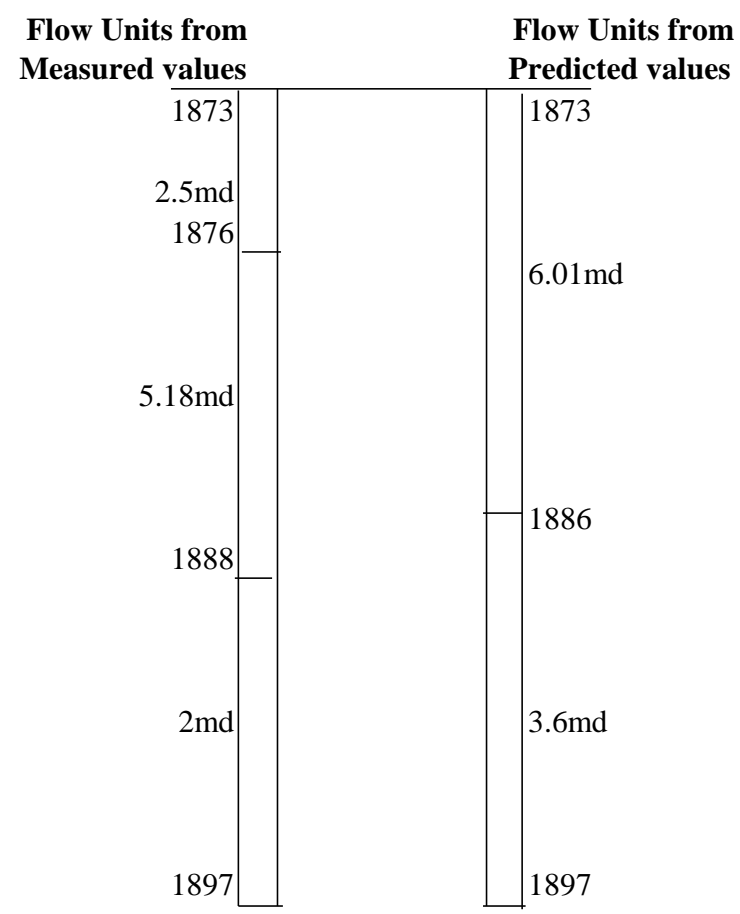

Figure 4.9.2 Comparison of flow units for well 15-1184 based on mean permeability from measured and predicted values. 


\subsection{Discussion of results from Test 10:}

In the tenth test, data set is divided into following two sets:

Set I: Development data set with permeability values from wells 15-733, 15-1059, 15$1107,15-1108,15-1109,15-1128,15-1130,15-1132,15-1184$.

Set II: Validation Data Set with permeability values from well 15-1309.

The permeability prediction model is given by:

\section{$\log K=16.888-6.4548 X$,}

where $\mathrm{X}$ is the density from the log of the well.

Figure 4.10.1 shows the comparison of the predicted permeability and measured core permeability at different depths of the well. The predicted flow units are compared with the flow units obtained by using measured permeability from data Set II and the results are shown in Figure 4.10.2. Figure 4.10.1 shows that the predicted permeabilities are lower compared to measured permeabilities at initial depths but at deeper zones of the well they are in good agreement.

The Figure 4.10.2 shows that the predicted model divides the well into three zones whereas the original data shows that the well has two zones. Though the predicted mean permeability values deviate from the original mean permeability values, it is clear that the high permeability and low permeability zone predictions are similar. The zonal divisions at correct depth appears to be more significant than the absolute permeability values at certain depth. Thus, it can be concluded that the model for well 15-1309 correctly predicts the high permeability and low permeability zones. 


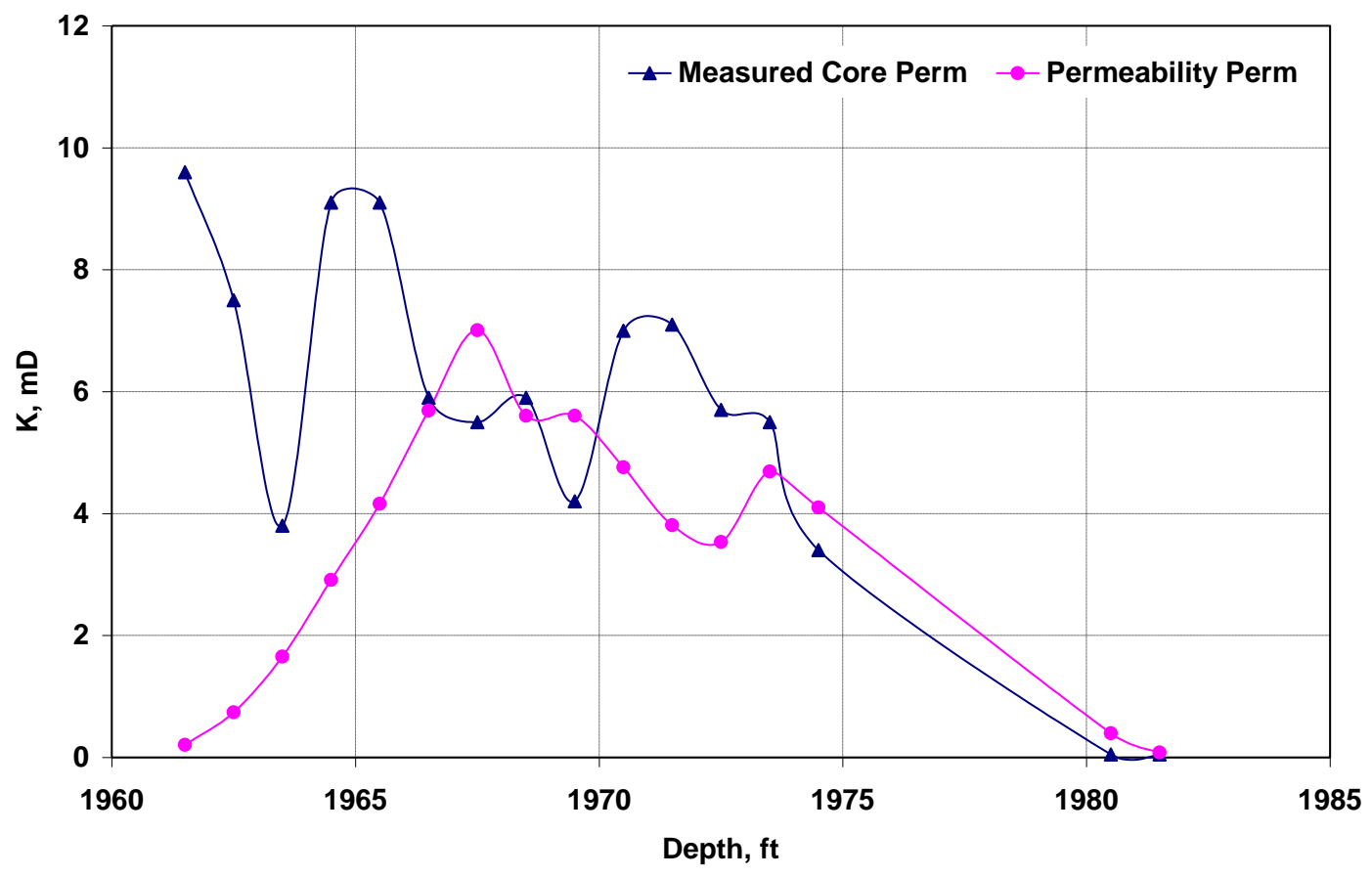

Figure 4.10.1 Comparison of M easured and Predicted per meability values for well 15-1309.

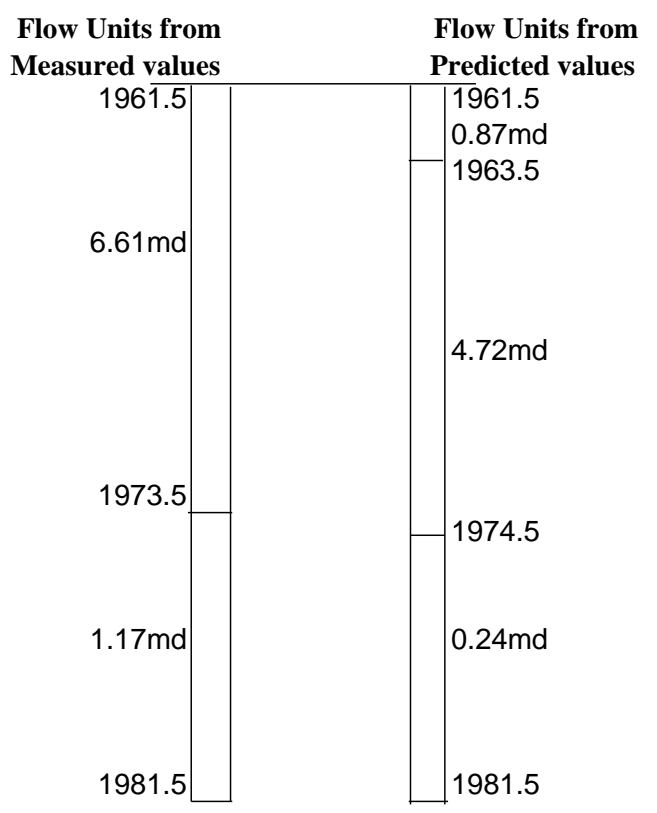

Figure 4.10.2 Comparison of flow units for well 15-1309 based on mean permeability from measured and predicted values. 


\subsection{Correlation of flow units using measured permeability data from cored wells:}

The ultimate objective is to predict the flow unit strata of the reservoir through unknown wells given that the flow strata for the adjacent wells are known. After the flow units are identified in the entire ten cored wells, additional wells are randomly selected from the ten cored wells to identify the flow unit strata among wells. Using the method described in Section 3.5 the correlation of flow units among wells are determined as shown in Section F2 of Appendix F. The first set of wells selected for this correlation are 15-1309, 15-1184, 15-1107 and 15-1108 and they show a trend in the north-east direction. All the depths shown in the figures in section 4.11 and section 4.12 are sub sea level depths in feet.

Figure 4.11.1 shows the correlation of flow units from measured permeability data for wells 15-1309, 15-1184, 15-1107 and 15-1108. As shown in Figure 4.11.1 the well 151309 has two flow units, the wells 15-1184 and 15-1107 have three flow units and the well 15-1108 has four flow units. From the flow unit correlation shown in Section F2 of Appendix F, the first zone of well 15-1309 correlates with second zone of well 15-1184, the second zone of the well 15-1184 correlates with the second zone of well 15-1107 and the second zone of the well 15-1107 correlates with second, third and fourth zones of the

well 15-1108. Figure 4.11.1 clearly tells us that the high permeability zone is a continuous stratum over these wells. 


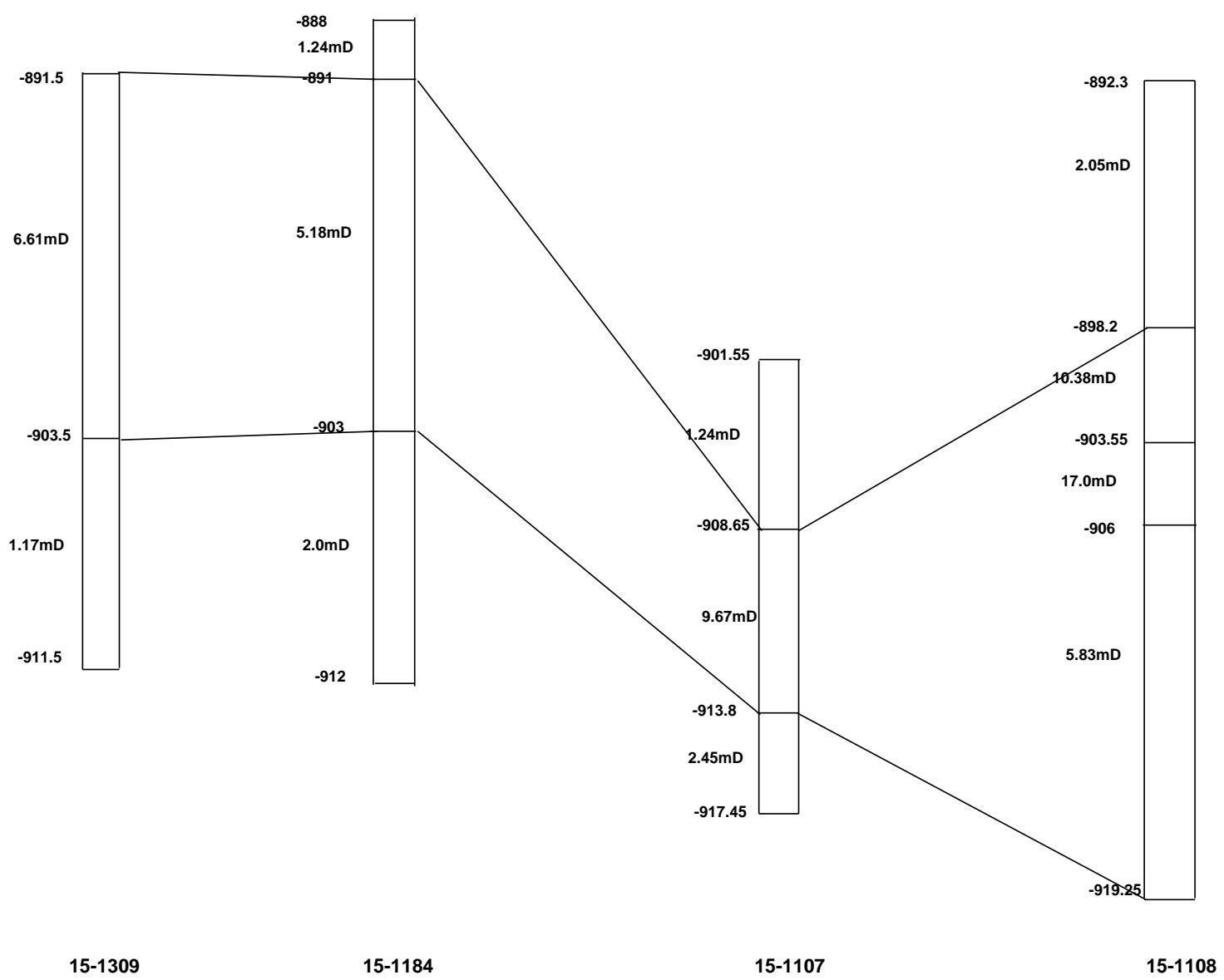

Figure 4.11.1 C orrelation of flow units from measured permeability data for wells 15-1309, 15-1184, 15-1107 and 15-1108.

Figure 4.11.2 shows the correlation of flow units from measured permeability data for wells 15-1109, 15-1132 and 15-1108. As shown in Figure 4.11.2 the well 15-1109 has two flow units, the well 15-1132 has three flow units and the well 15-1108 has four flow units. From the flow unit correlation presented in Section F2 of Appendix F, zones of well 15-1109 does not correlate with any zone of well 15-1132, where as the first zone of the well 15-1132 correlates with second, third and fourth zones of the well 15-1108. 
Since, the mean of measured permeability values in both zones of the well 15-1109 are very small compared to the mean of measured permeability values in both zones of well 15-1132. Figure 4.11.2 shows that the high permeability zone is a continuous stratum over the wells 15-1132 and 15-1108.

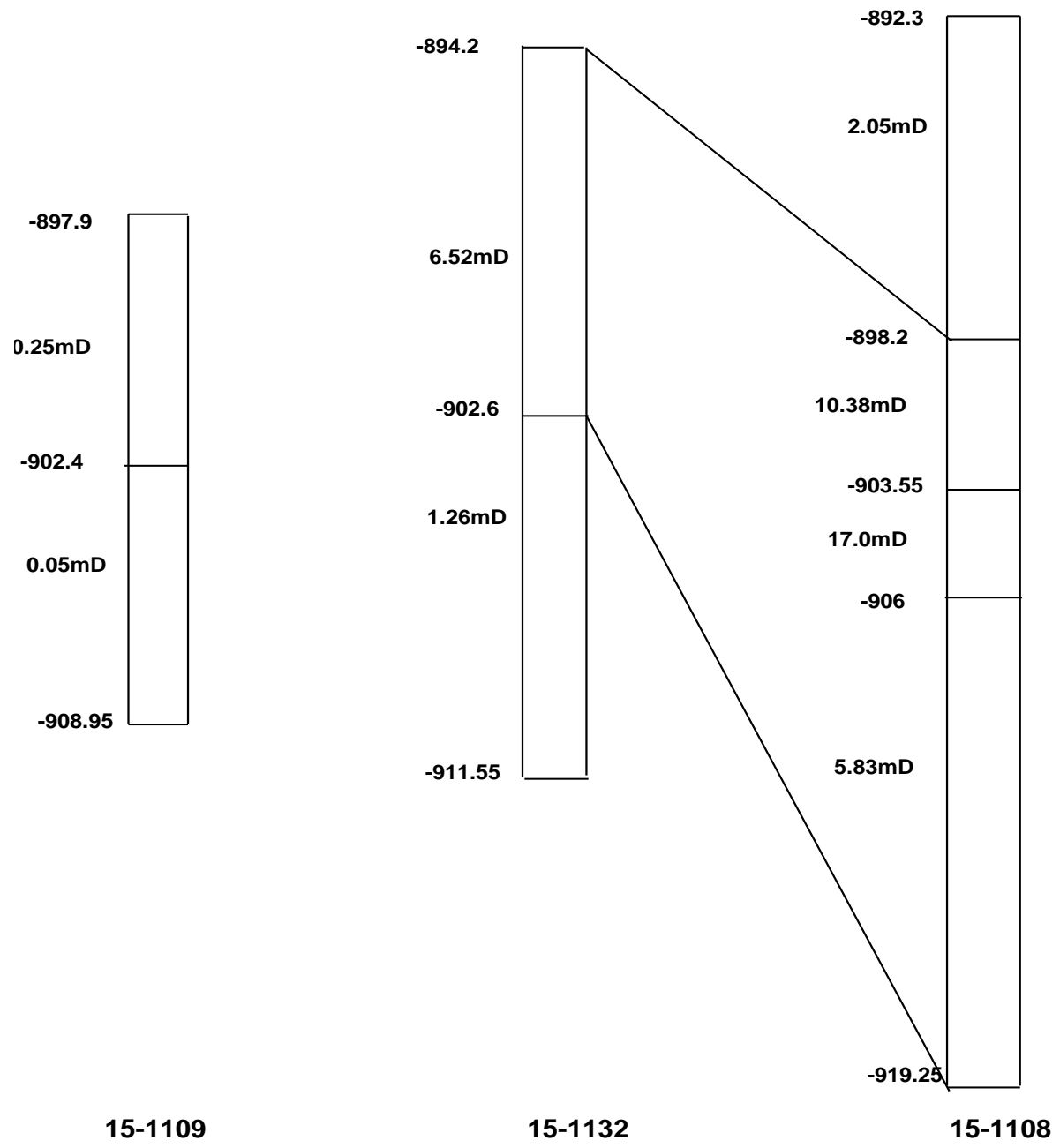

Figure 4.11.2 C orrelation of flow units from measured permeability data for wells 15-1109, 15-1132 and 15-1108.

Figure 4.11.3 shows the correlation of flow units from measured permeability data for wells 15-1128, 15-1130 and 15-1108. As shown in Figure 4.11.3 the well 15-1128 has three flow units, the well 15-1130 has two flow units and the well 15-1108 has four flow 
units. From the flow unit correlation shown in Section F2 of Appendix F, the first zone of well 15-1128 correlates with the first zone of well 15-1130 and the first zone of the well 15-1130 correlates with second, third and fourth zones of the well 15-1108, respectively. Figure 4.11.3 shows the continuity of the high permeability zone over the wells $15-1128$, $15-1130$ and $15-1108$.

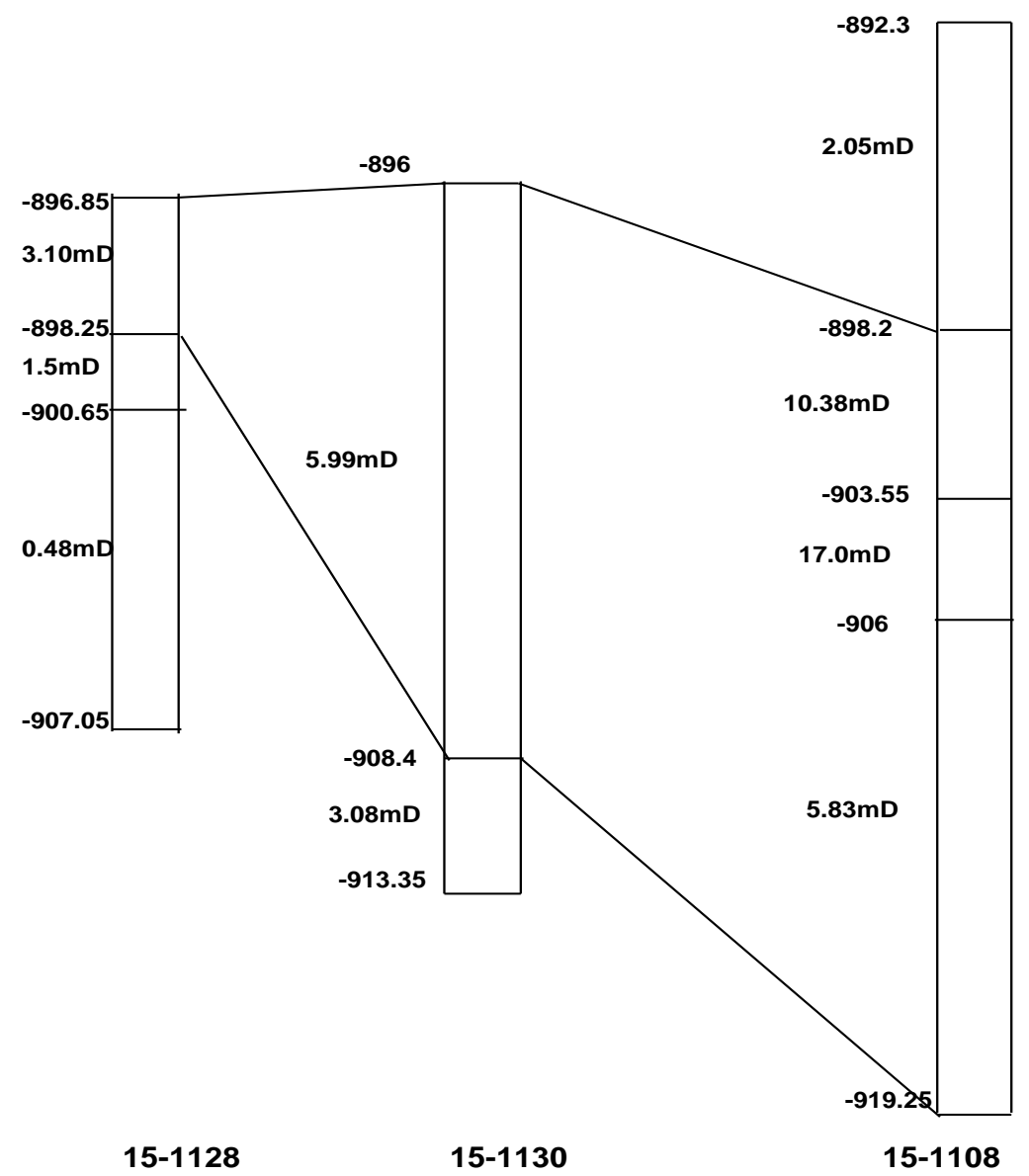

Figure 4.11.3 Correlation of flow units from measured permeability data for wells 15-1128, 15-1130 and 15-1108.

Figure 4.11.4 shows the correlation of flow units from measured permeability data for wells 15-733, 15-1128, 15-1132 and 15-1107. As shown in Figure 4.11.4 the wells 15733 and 15-1128 have three flow units, the well 15-1132 has two flow units and the well 
15-1107 has three flow units. From the flow unit correlation presented in Section F2 of Appendix F, the first zone of well 15-733 correlates with first zone of well 15-1128, the first zone of the well 15-1128 correlates with the first zone of well 15-1132 and the first zone of the well 15-1132 correlates with second zone of the well 15-1107. As shown in Figure 4.11.4 all highly permeable first zones are related in this cross-section.

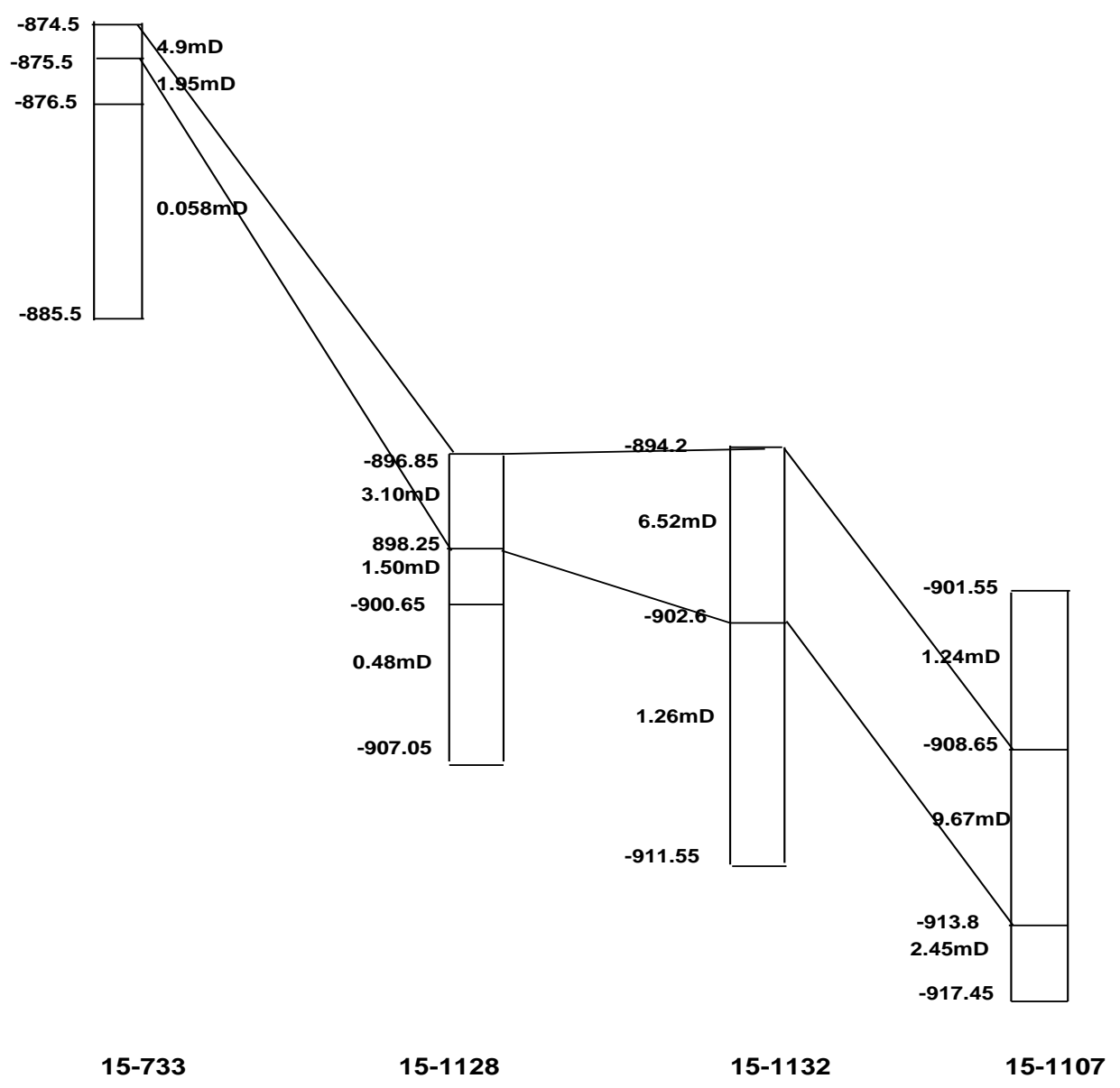

Figure 4.11.4 Correlation of flow units from measured permeability data for wells 15-733, 15-1128, 15-1132 and 15-1107. 


\subsection{Correlation of flow units from predicted permeability data for uncored wells:}

The permeability prediction model developed with the data from ten cored wells is discussed in Section 3.3.5. The flow units in those wells are identified and the procedure and results are presented in Appendix E. Using the technique described in Section 3.5 the flow units for these uncored wells are correlated with the procedure and calculation given in Section F3 of Appendix F.

Figure 4.12.1 shows the correlation of flow units from predicted permeability data for wells 15-1110, 15-874 and 15-868. As shown in Figure 4.12.1, the wells 15-1110, 15-874 and 15-868 have two flow units. Based on the flow unit correlation given in Section F3 of Appendix F, the first zone of well 15-1110 correlates with the first zone of well 15-874 and the first zone of the well 15-874 further correlates with first zone of the well 15-868. As a result, a continuous high permeability zone exists between the wells 15-1110, 15874 and 15-868 as shown in Figure 4.12.1.

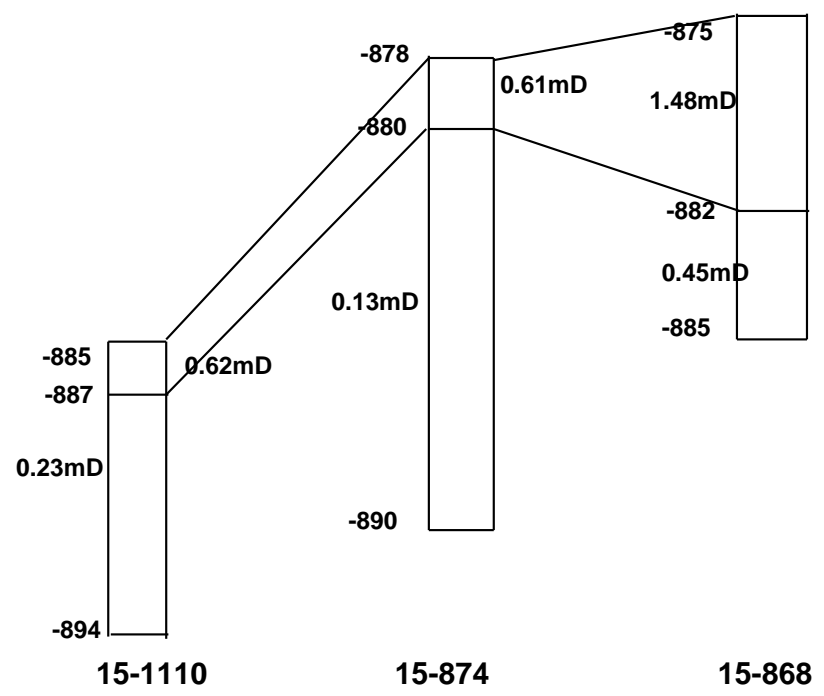

Figure 4.12.1 Correlation of flow units from predicted per meability data for wells 15-1110, 15-874 and 15-868. 
Figure 4.12.2 shows the correlation of flow units from predicted permeability data for wells 15-1621, 15-1639 and 15-1783. As shown in Figure 4.12.2, the wells 15-1621, 151639 and 15-1783 have three flow units. From the flow unit correlation presented in Section F3 of Appendix F the second zone of well 15-1621 correlates with the second zone of well 15-1639 and the second zone of the well 15-1639 further correlates with second zone of the well 15-1783. Therefore, the high permeability zones between the wells 15-1110, 15-874 and 15-868 correlate as a single unit as shown in Figure 4.12.2.

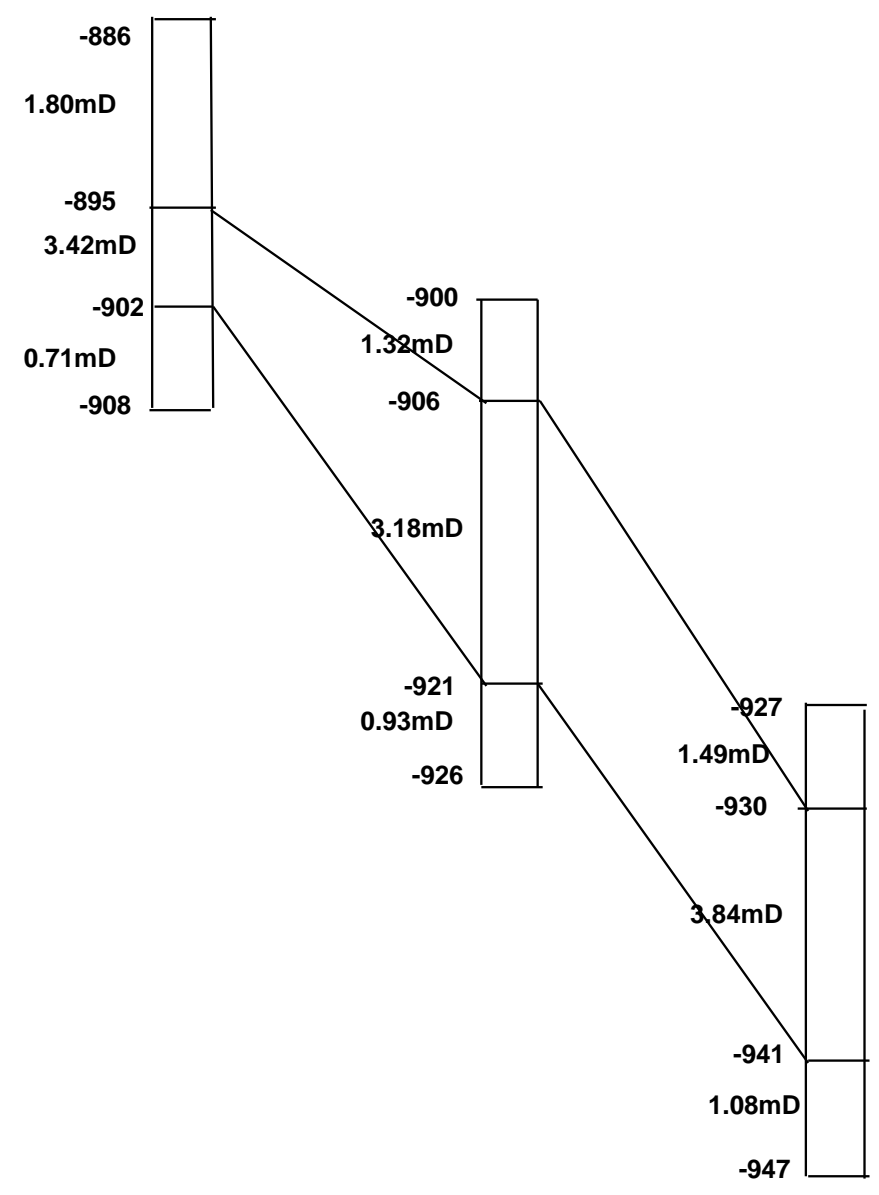

$15-1621$

15-1639

15-1783

Figure 4.12.2 Correlation of flow units from predicted per meability data for wells 15-1621, 15-1639 and 15-1783. 
Figure 4.12.3 shows the correlation of flow units from predicted permeability data for wells 15-2150, 15-2215 and 15-1639. As shown in Figure 4.12.3, the wells 15-2150 and 15-2215 have two flow units each and the well 15-1639 has three flow units. From the flow unit correlation given in Section F3 of Appendix F, the second zone of well 15-2150 correlates with the second zone of well 15-2215 and the second zone of the well 15-2215 further correlates with second zone of the well 15-1639. The high permeability zone is shown in Figure 4.12.3 for the wells15-2150, 15-2215 and 15-1639.

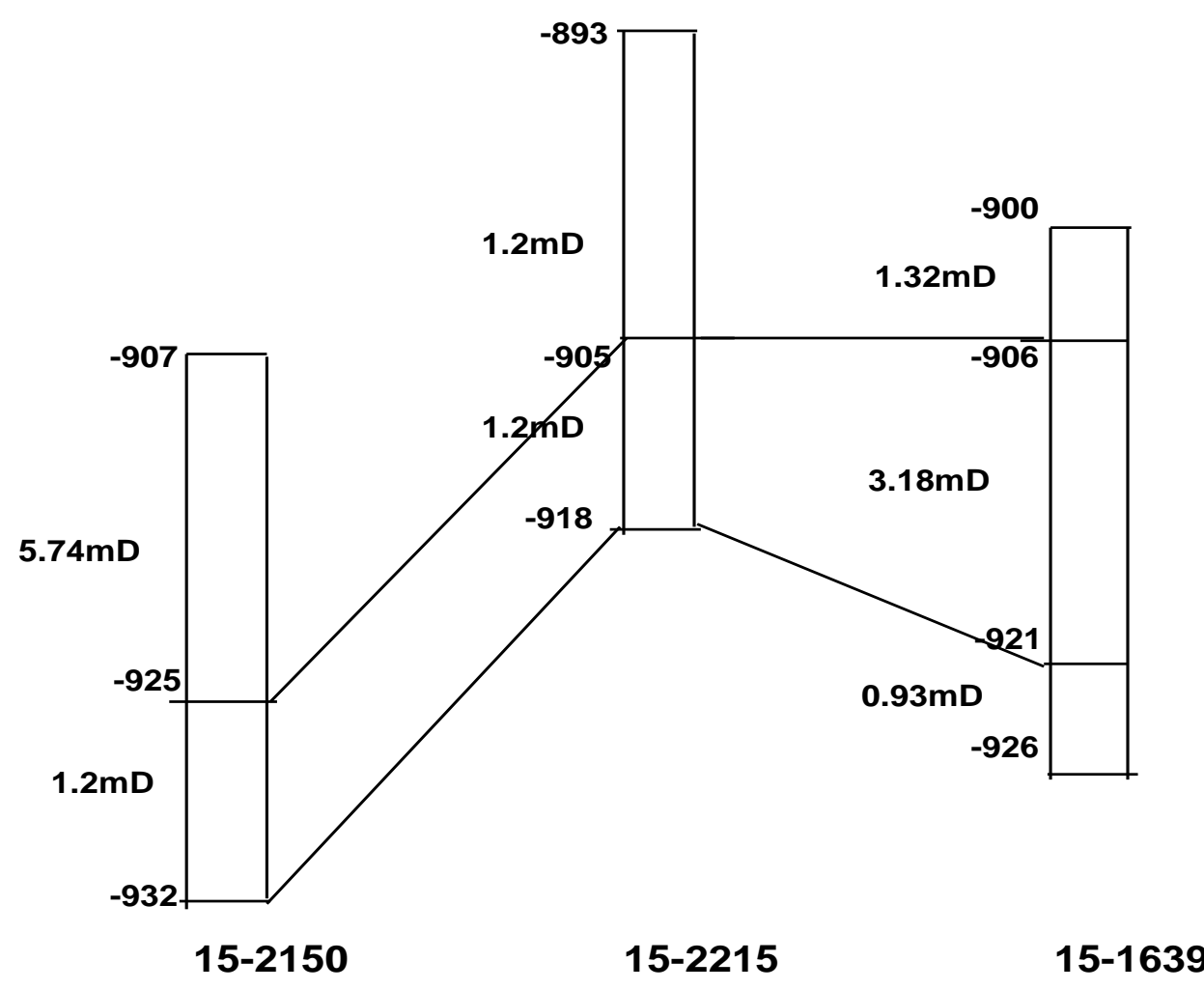

\section{Figure 4.12.3 Correlation of flow units from predicted per meability data for wells 15-2150, 15-2215 and 15-1639.}

Figure 4.12.4 shows the correlation of flow units from predicted permeability data for wells 15-1176 and 15-1225. As shown in Figure 4.12.4 the well 15-1176 has two flow units and the well 15-1225 has three flow units. Based on the flow unit correlation 
calculations presented in Section F3 of Appendix F, the first zone of well 15-1176 correlates with the second zone of well 15-1225. The correlated permeability zones are shown in Figure 4.12.4 for wells 15-1176 and 15-1225.

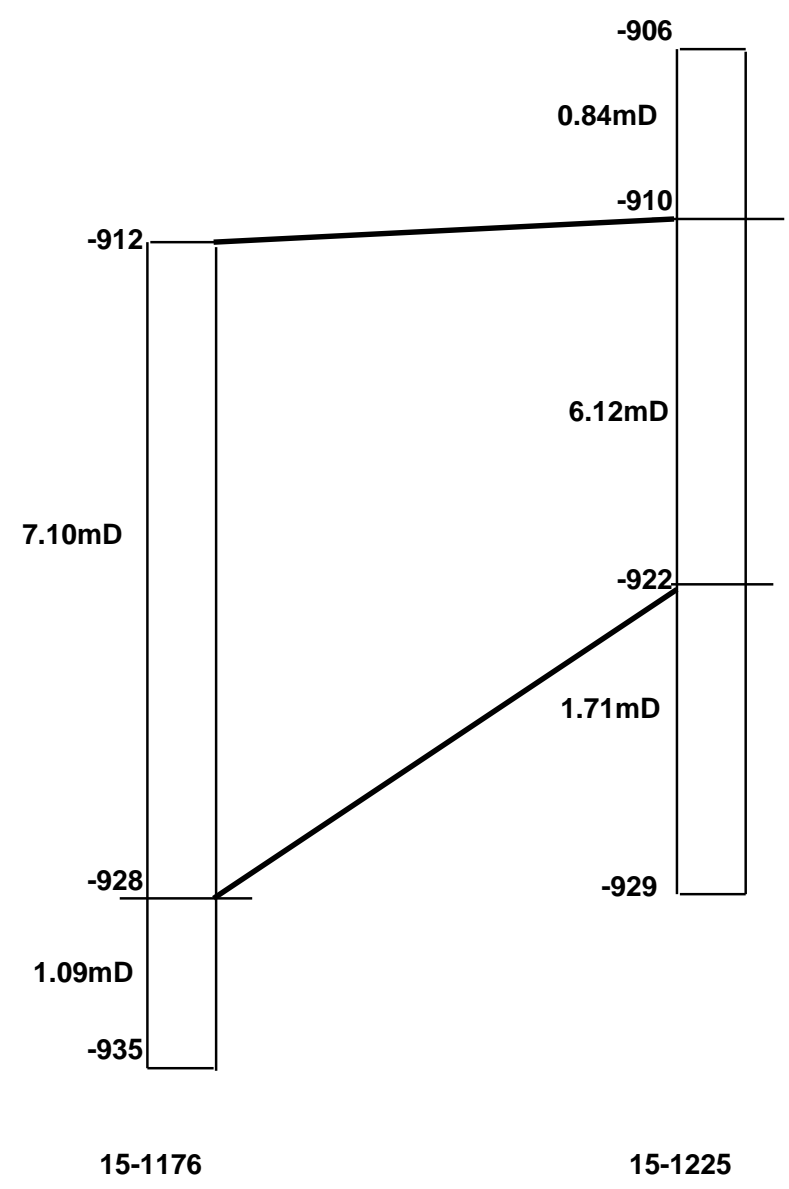

Figure 4.12.4 Correlation of flow units from predicted per meability data for wells 15-1176 and 15-1225. 


\section{CHAPTER 5}

\section{CONCLUSIONS AND RECOMMENDATIONS}

This research provides a solution to dividing a reservoir into flow zones with respect to their physical properties. The following conclusions are made based on the results obtained from the study:

1. A model for predicting the flow units has been developed using density from the $\log$ and limited core permeability from ten wells.

2. A linear relationship between density from $\operatorname{logs}$ (D) and logarithm of core permeability $(\mathrm{K})$ has been established to predict the permeability in wells without core data.

3. Statistical Zonation Technique has shown how basic statistical tools can be used as a means to uniquely sub-dividing reservoir into volumes that are more homogeneous.

4. A model was developed to extend the application of statistical zonation technique to the wells without core data by utilizing the predicted permeability values from $\log$ data.

5. The accuracy of the methodology was verified by comparing the original flow units with the predicted flow units in the wells with core data.

6. Zone predictions with predicted permeability values deviate from zone predictions with measured permeability values where the magnitudes of permeability values are smaller than $1 \mathrm{mD}$. 


\section{Recommendations:}

1. The correlation between density and permeability is not very strong based on the $\mathrm{R}^{2}$ values. A better correlation can give accurate predicted permeability.

2. A multiple regression technique using density from the log and core permeability may give a better permeability prediction tool.

3. Further research to determine the minimum number of wells with core data will be beneficial in the application of this method to a new field. 


\section{R eferences}

1. Testerman, J. D.: “A Statistical Reservoir-Zonation Technique” SPE. JPT, pp.889-893, Aug. 1962.

2. Abbaszadeh, M.D., Hikari, F., Fujio, F.: "Permeability Prediction by Hydraulic Flow Units-Theory and Applications” SPE 30158, 1996.

3. Amaefule, J.O.: “A flow unit approach on integrated reservoirs.” World Expo,. pp 25-31, 1995.

4. Amaefule, J. O., Altunbay, M. H., Tiab, D., Kersey, D. G. and Keelan, D. K.:

"Enhanced reservoir description using core and log data to identify hydraulic (flow) units and predict permeability in uncored intervals/wells.” SPE 26436, 1993.

5. Anderberg, M.R.: “Cluster Analysis For Applications,” Academic Press, New York, NY, 1973.

6. Abbaszadeh, M.D. and Brigham, W.E.: “Analysis of Well-to-Well Tracer Flow to Determine Reservoir Layering,” JPT, 1753-62, October 1984.

7. Graybill, F. A.: “An Introduction to Linear Statistical Hypothesis.” McGraw Hill, New York - 1961.

8. Molnar, D.: “The Use of Geophysical Well Log Data for Permeability Estimation in a Heterogeneous Reservoir”, Master】s Thesis, West Virginia University, 1994.

9. Lacentre, P. E., Carrica, M. P.: “A Method to Estimate Permeability on Uncored wells Based on Well Logs and Core Data,” SPE 81058, 2003.

10. Lawal, K. A., Onyekonwu, M. O.: “A Robust Approach to Flow Unit Zonation,” SPE 98830, 2005. 
11. Mustafa, R.: “Application of Statistical Methods For “Flow Unit” Identification and Characterization of a Reservoir Using Well Log and Core Data”, Master】s Thesis, West Virginia University, 2003.

12. Gunter, G., Finneran, J., Hartmann, D., Miller, J., "Early Determination of Reservoir Flow Units Using An Integrated Petrophysical Method,” SPE 38679, 1997.

13. Thomas, B. H.: "Flow Unit Prediction Using Limited Permeability Data Using Artificial Neural Network Analysis”, Dissertation, West Virginia University, 2002.

14. Alla, V. K.: "Using Waterflood Performance to Characterize Flow-Units Ina Heterogeneous Reservoir”, Master】s Thesis, West Virginia University, 2002.

15. Molnar, D., Aminian, K., and Ameri, S.: "The Use of Well Log Data for Permeability Estimation in a Heterogeneous Reservoir”, SPE 29175, Proceedings of SPE Eastern Regional Conference, pp 167-180, 1994.

16. Aminian, K.: "Characterization of a Complex Reservoir in West Virginia", SPE 26939, 1994.

17. Neter, J., Wasserman, W., Kutner, W.H., Homewood, III., R. D.: “Applied Linear Statistical Models” Irwin, 1974.

18. Harter, H.L.: “Critical Values for Duncan\s New Multiple Range Test”, Biometrics 16, 671, 1960. 


\section{APPE NDIX A \\ Distribution of Density from the $L$ og and C ore Permeability in cored \\ wells.}




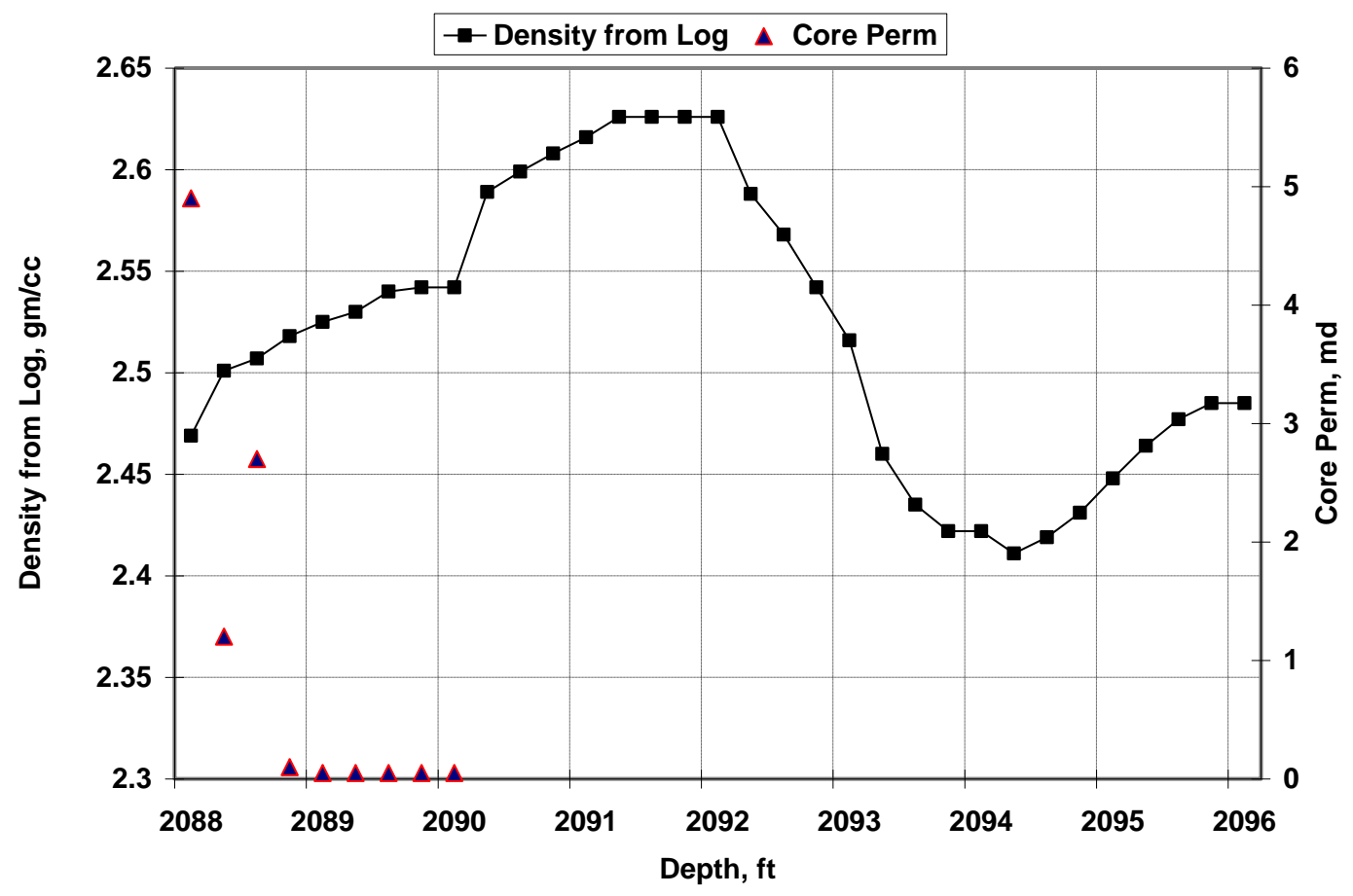

Figure A. 1 Density from the $L$ og and C ore Permeability distribution for well 15-733.

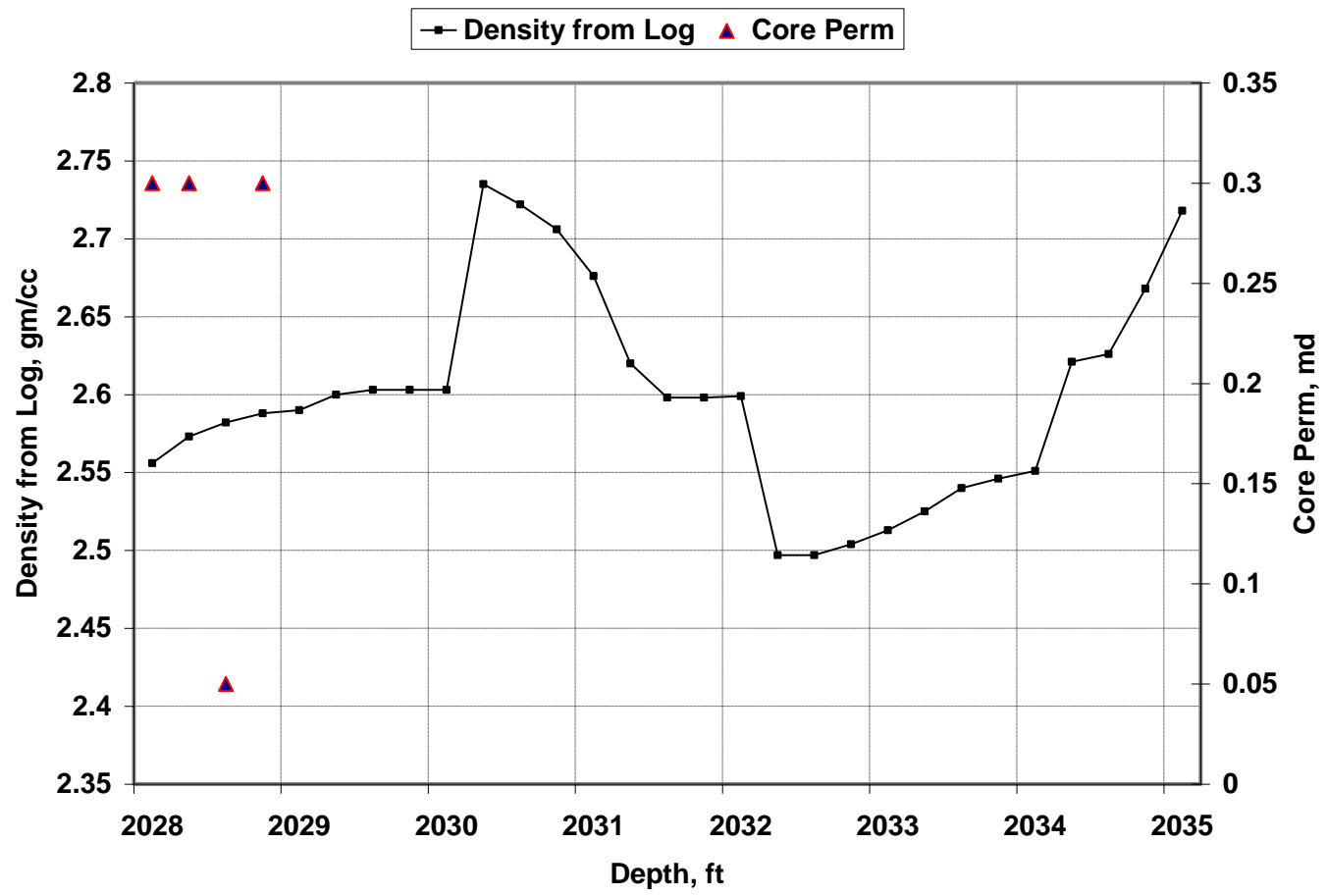

Figure A. 2 Density from the Log and C ore Permeability distribution for well 15-1059. 


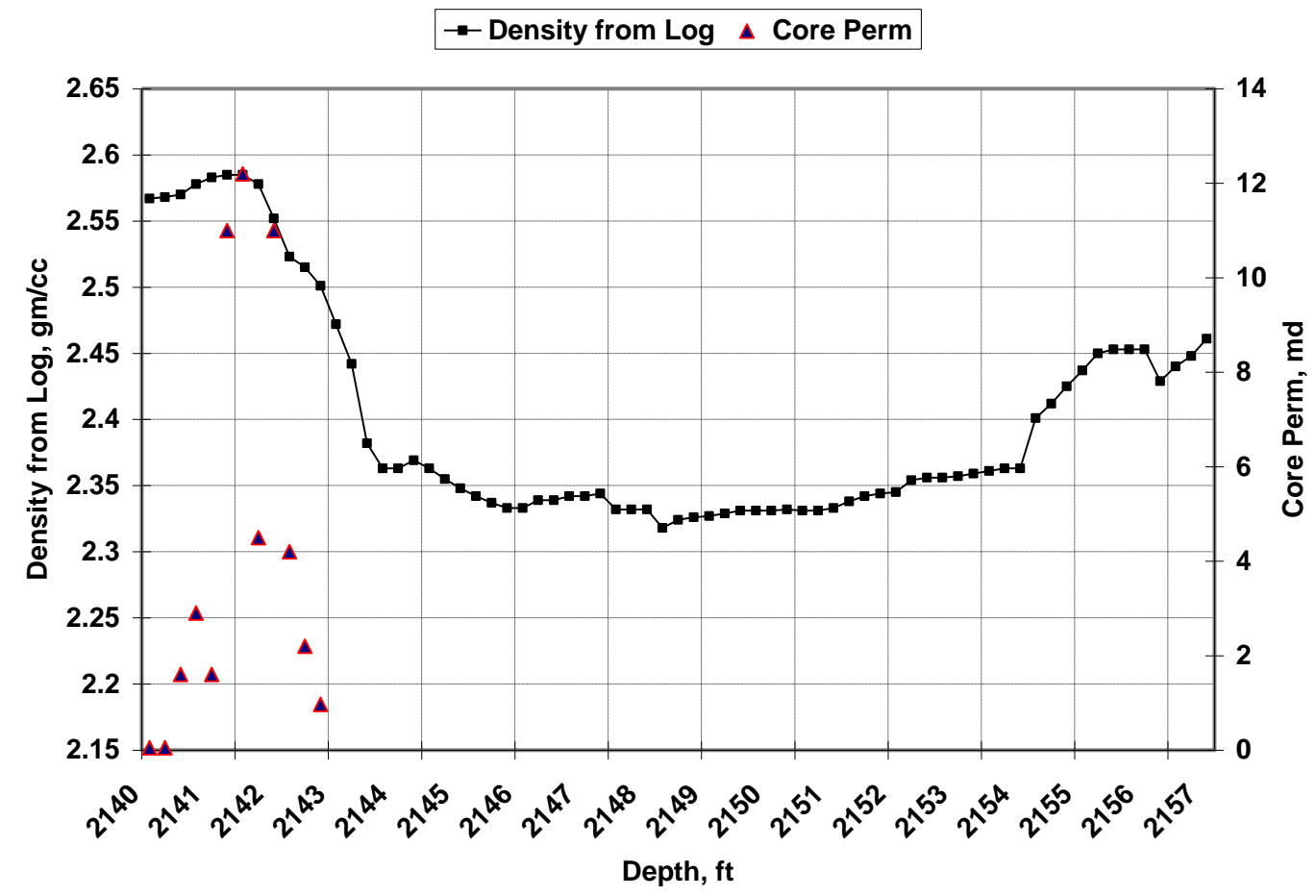

Figure A. 3 Density from the Log and C ore Permeability distribution for well 15-1107.

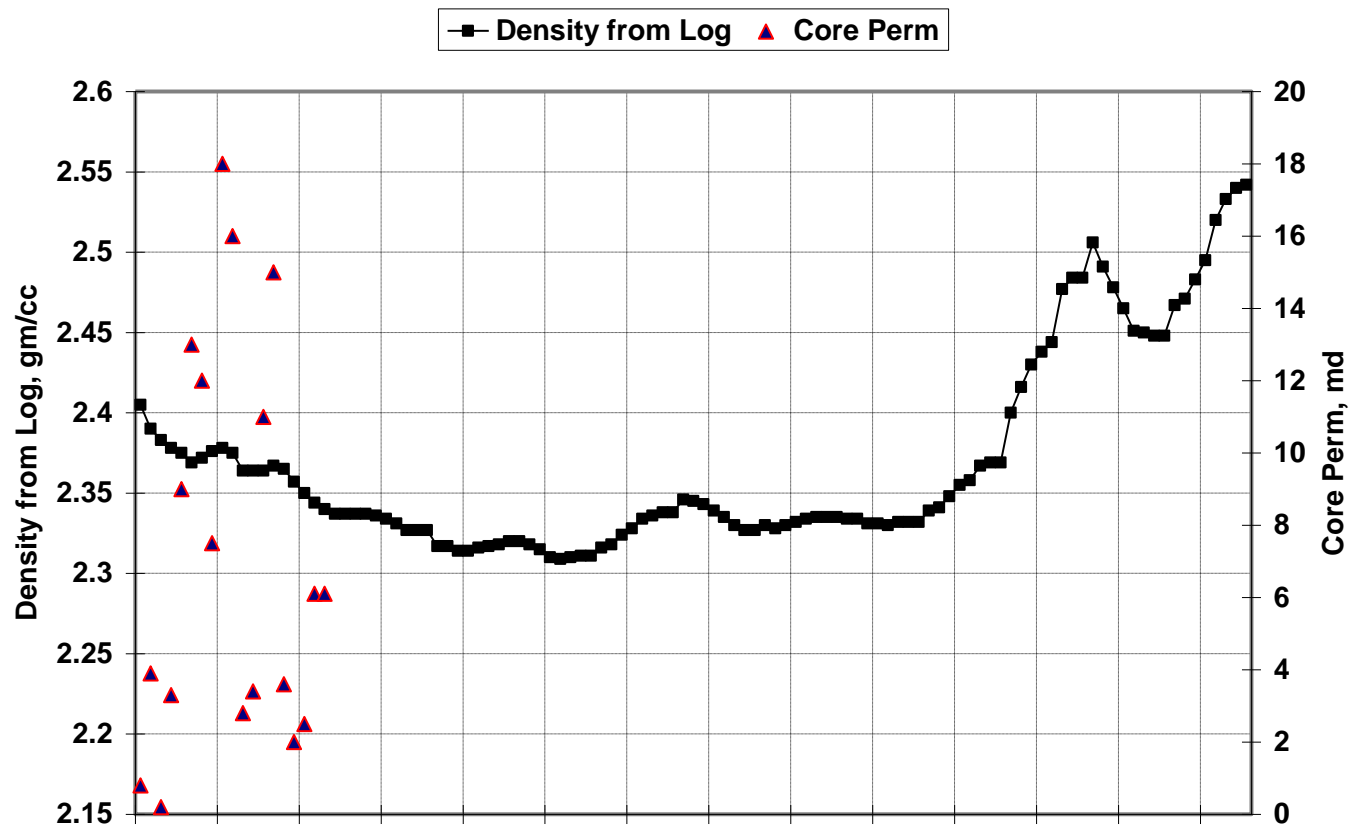

20652067206920712073207520772079208120832085208720892091

Depth, ft

Figure A. 4 Density from the Log and C ore Permeability distribution for well 15-1108. 


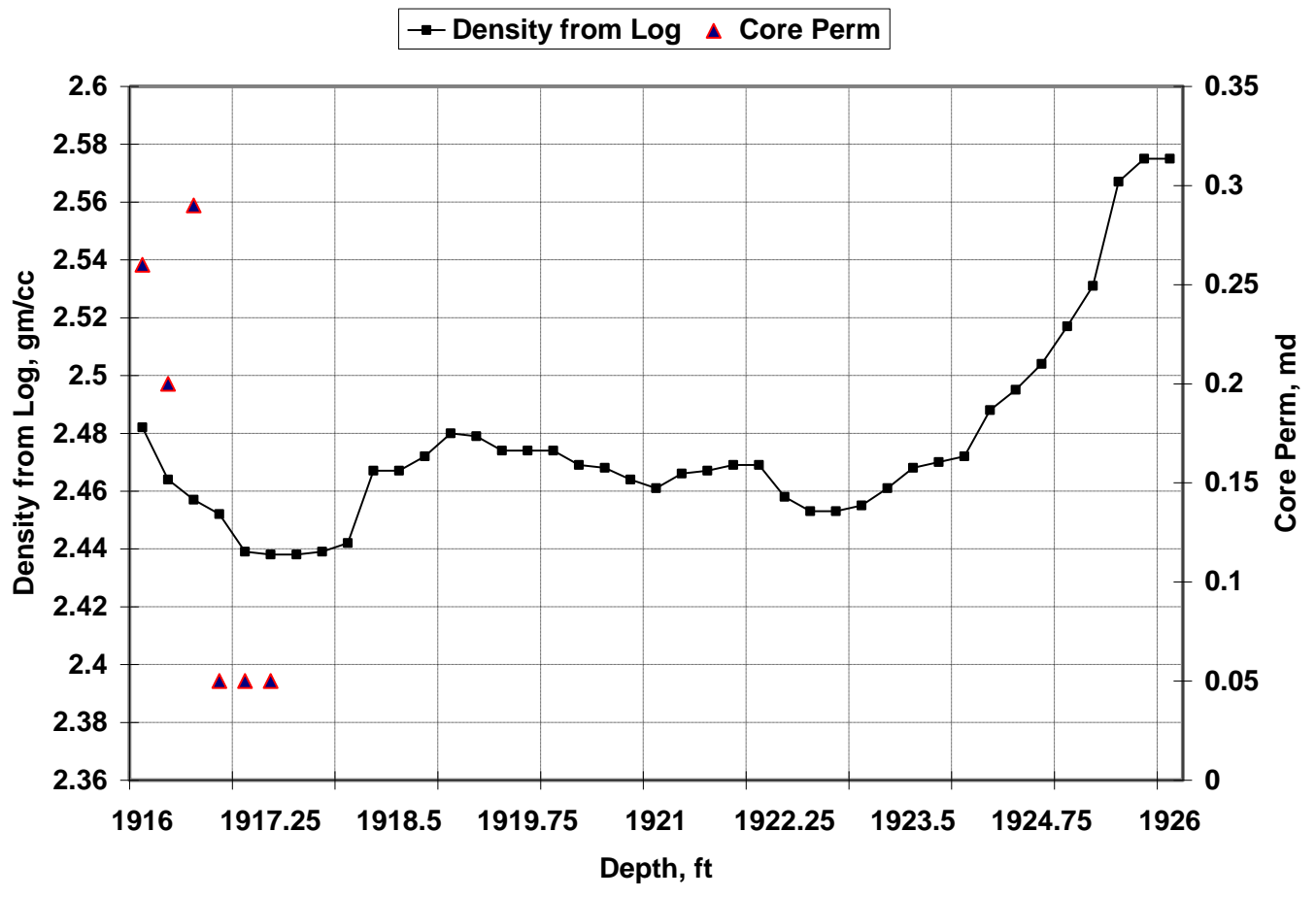

Figure A. 5 Density from the L og and C ore Permeability distribution for well 15-1109.

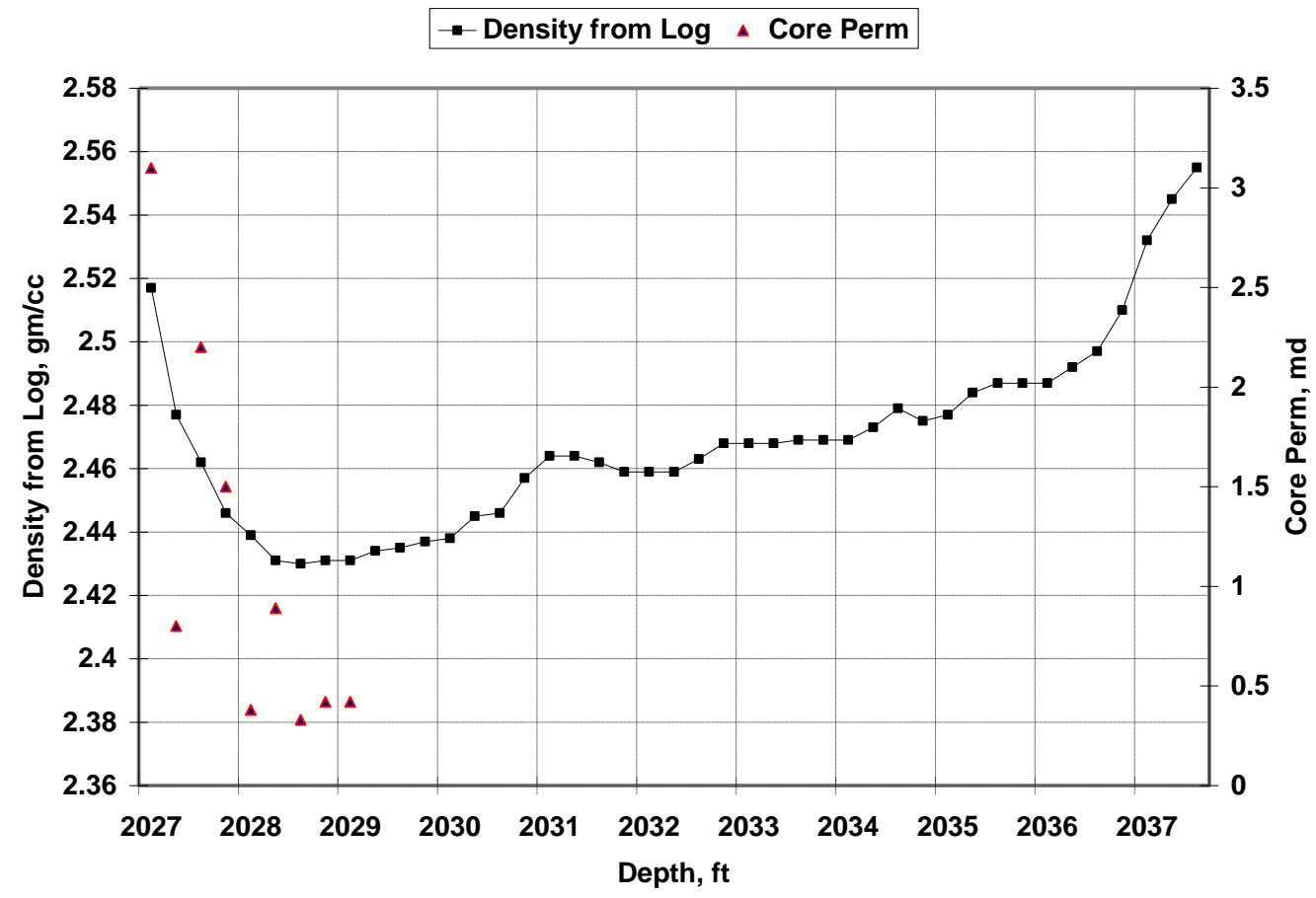

Figure A. 6 Density from the L og and C ore Permeability distribution for well 15-1128. 


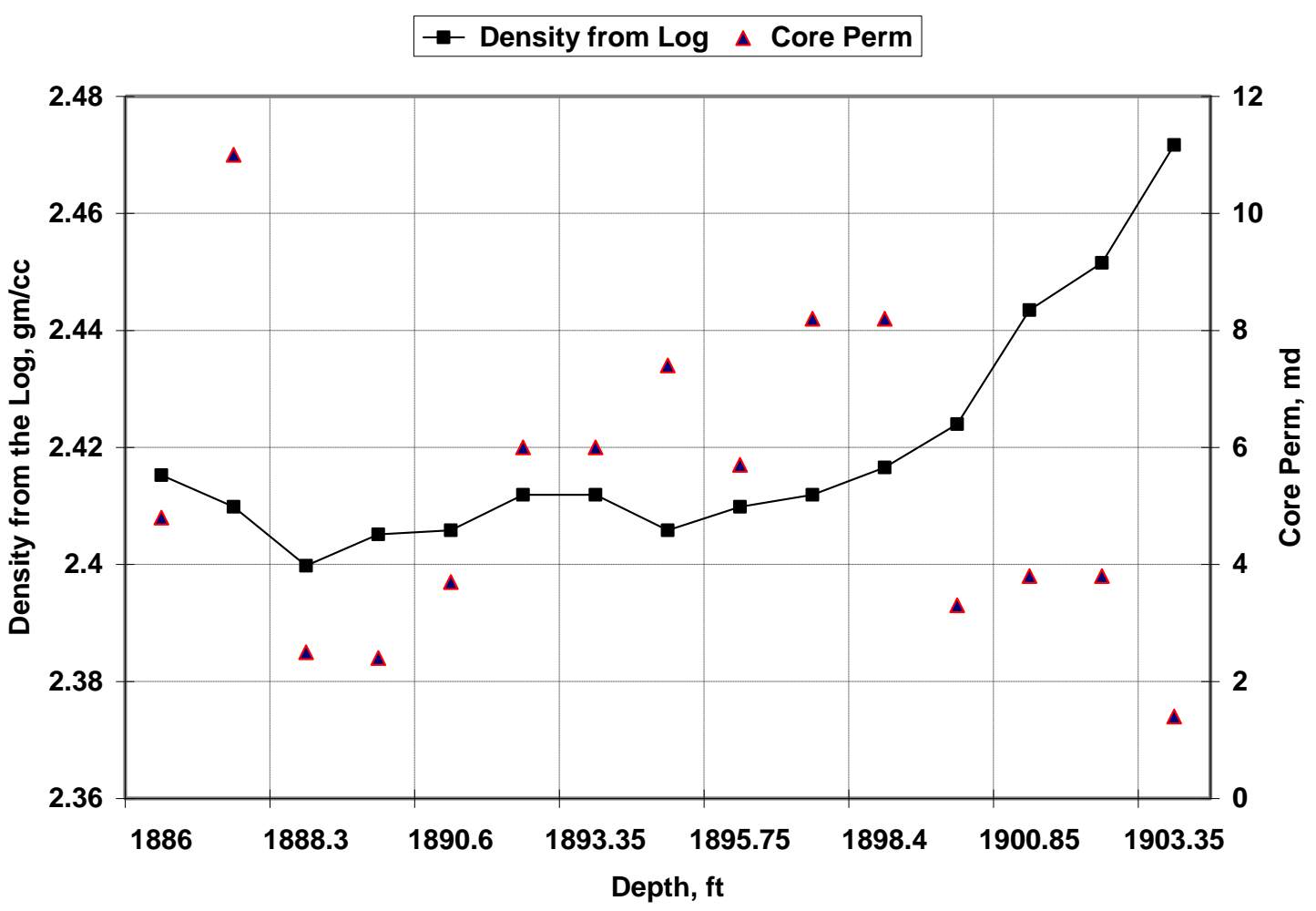

Figure A. 7 Density from the Log and C ore Permeability distribution for well 15-1130.

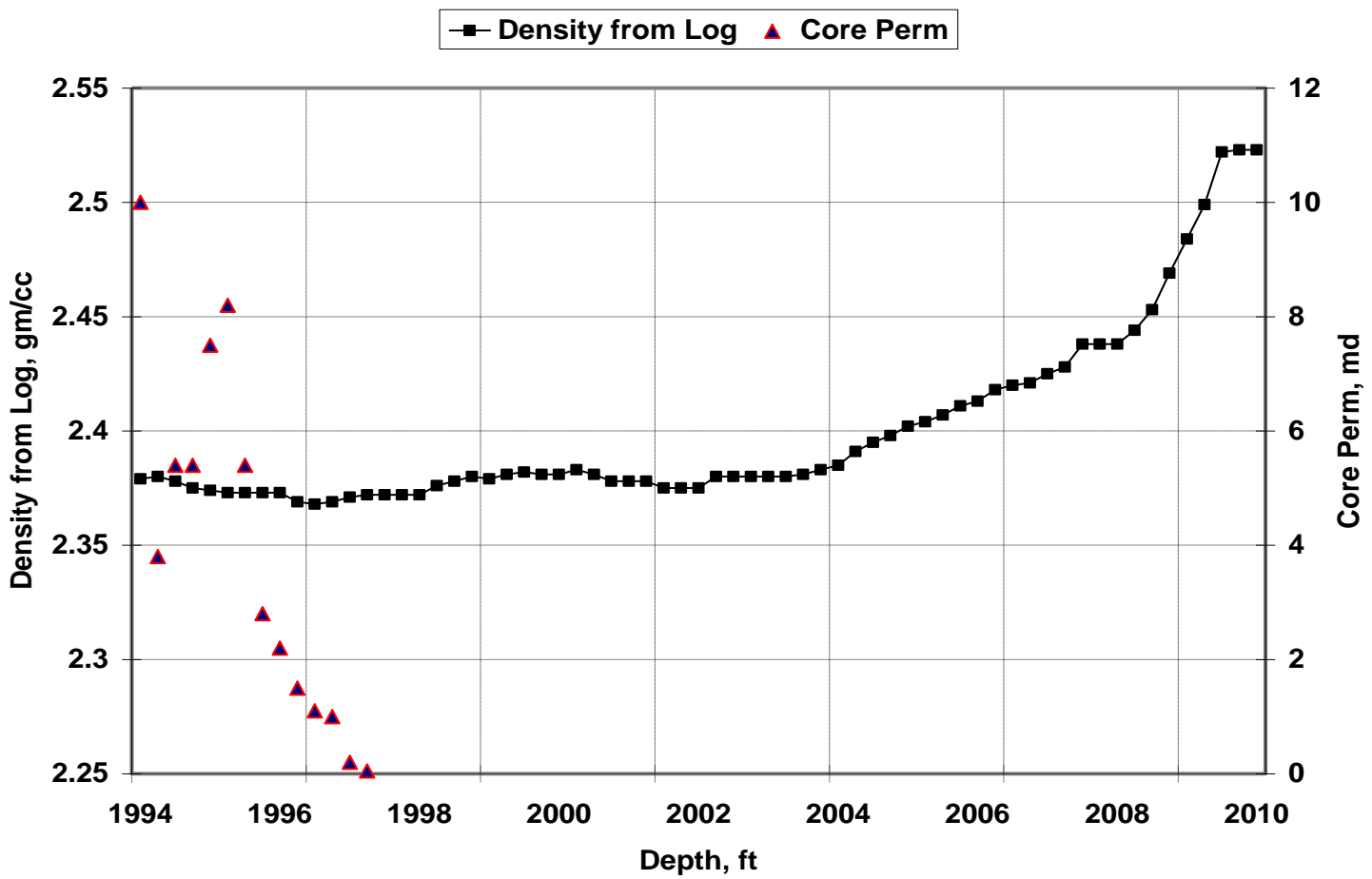

Figure A. 8 Density from the Log and C ore Permeability distribution for well 15-1132. 


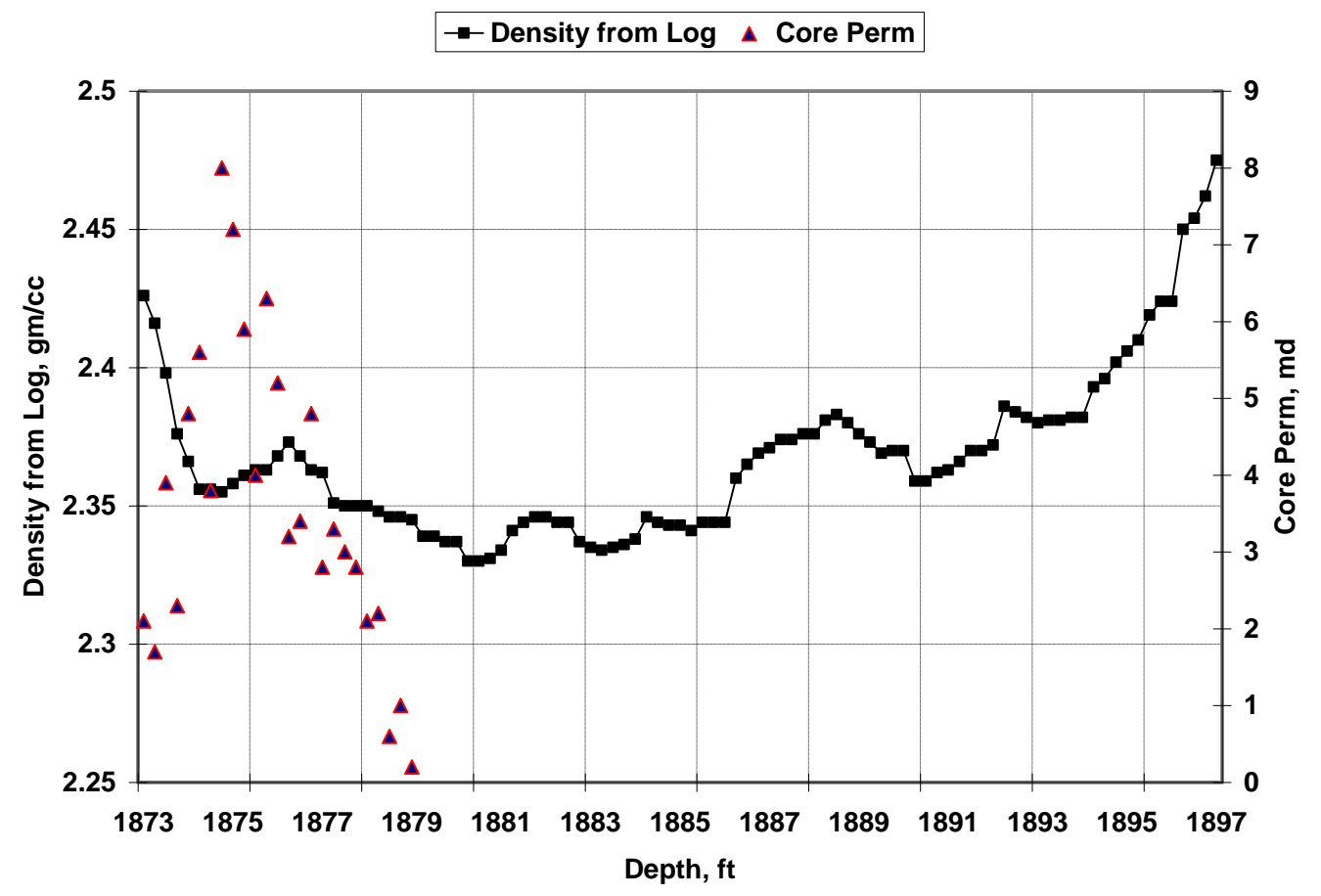

Figure A. 9 Density from the L og and C ore Permeability distribution for well 15-1184.

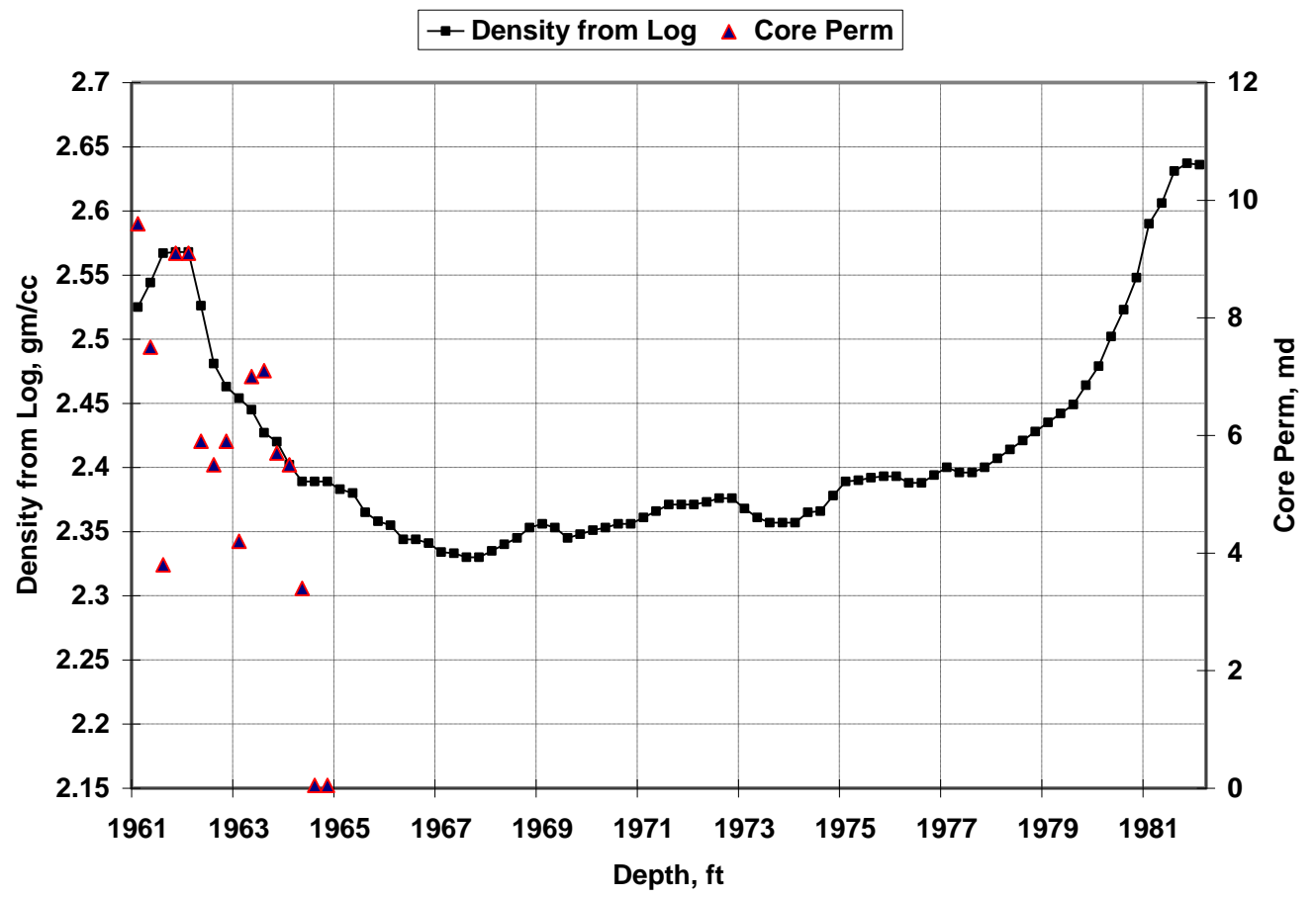

Figure A. 10 Density from the Log and C ore Permeability distribution for well 15-1309. 


\begin{abstract}
APPE NDIX B
Permeability predictions in cored wells using transformation approach.
\end{abstract}




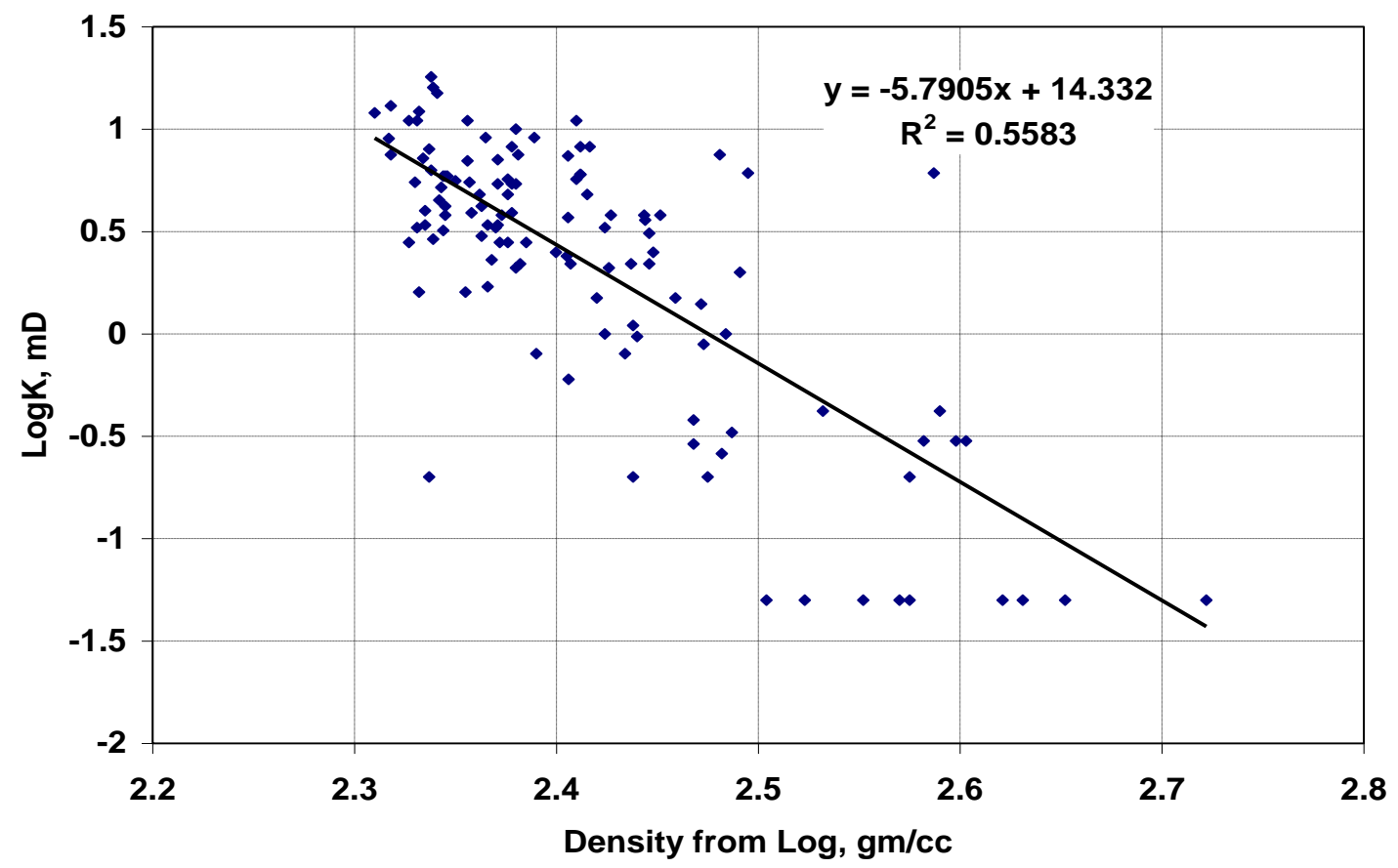

Figure B.1 L inear correlation between density from well log and logarithm of core permeability from Test 1 (except 15-733).

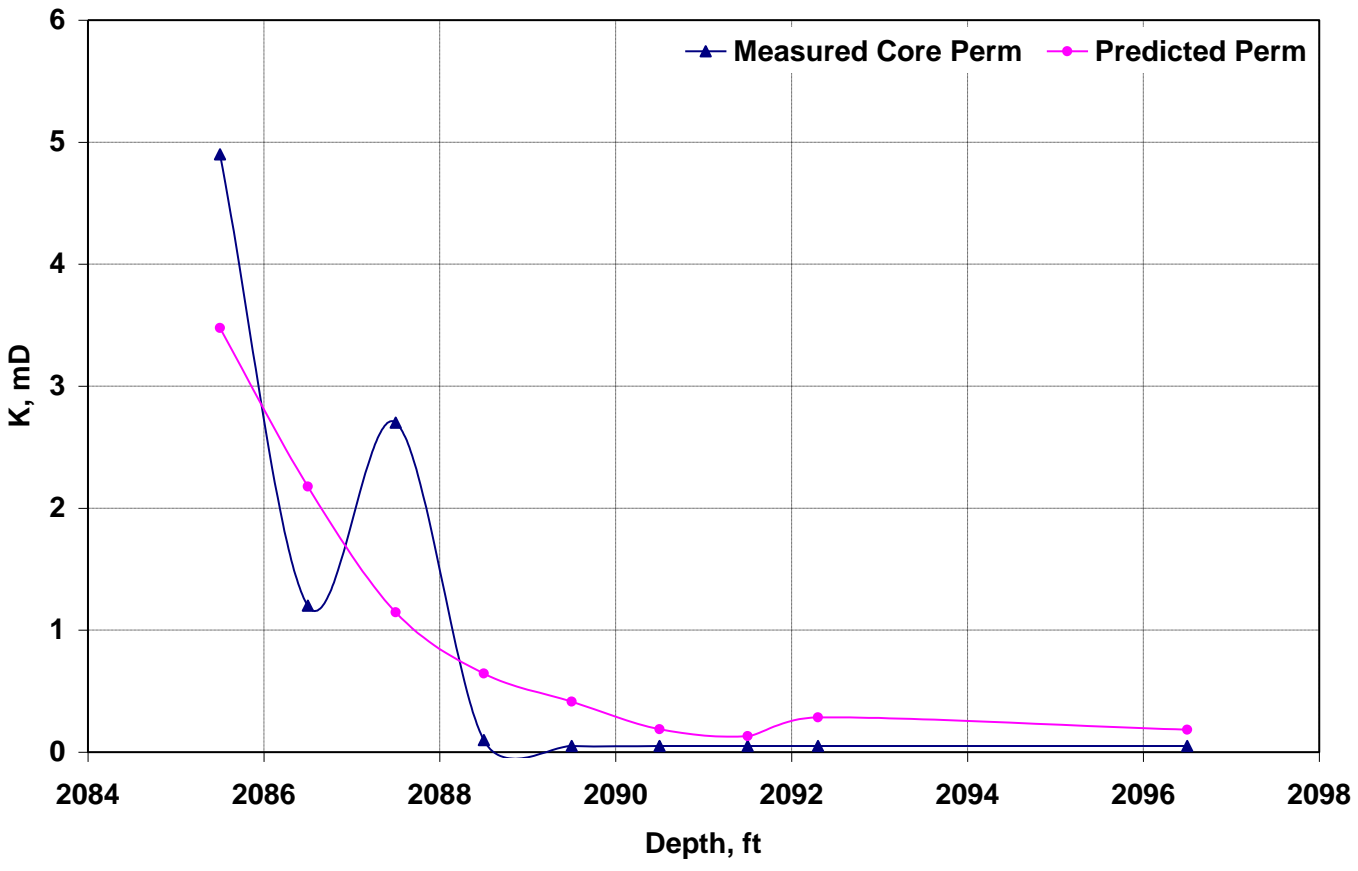

Figure B. 2 Permeability prediction for well 15-733. 


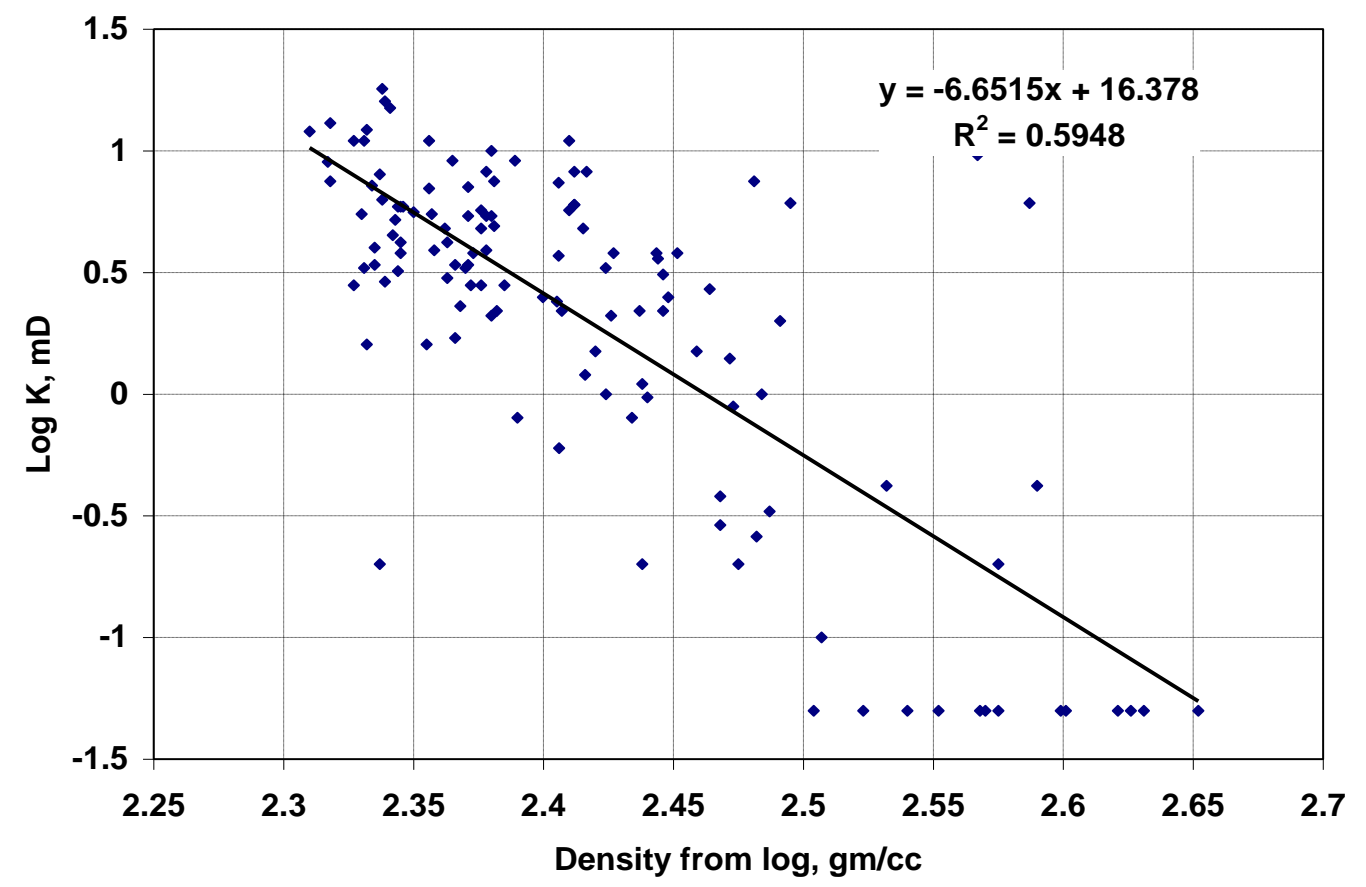

Figure B.3 Linear correlation between density from well log and logarithm of core permeability from Test 2 (except 15-1059).

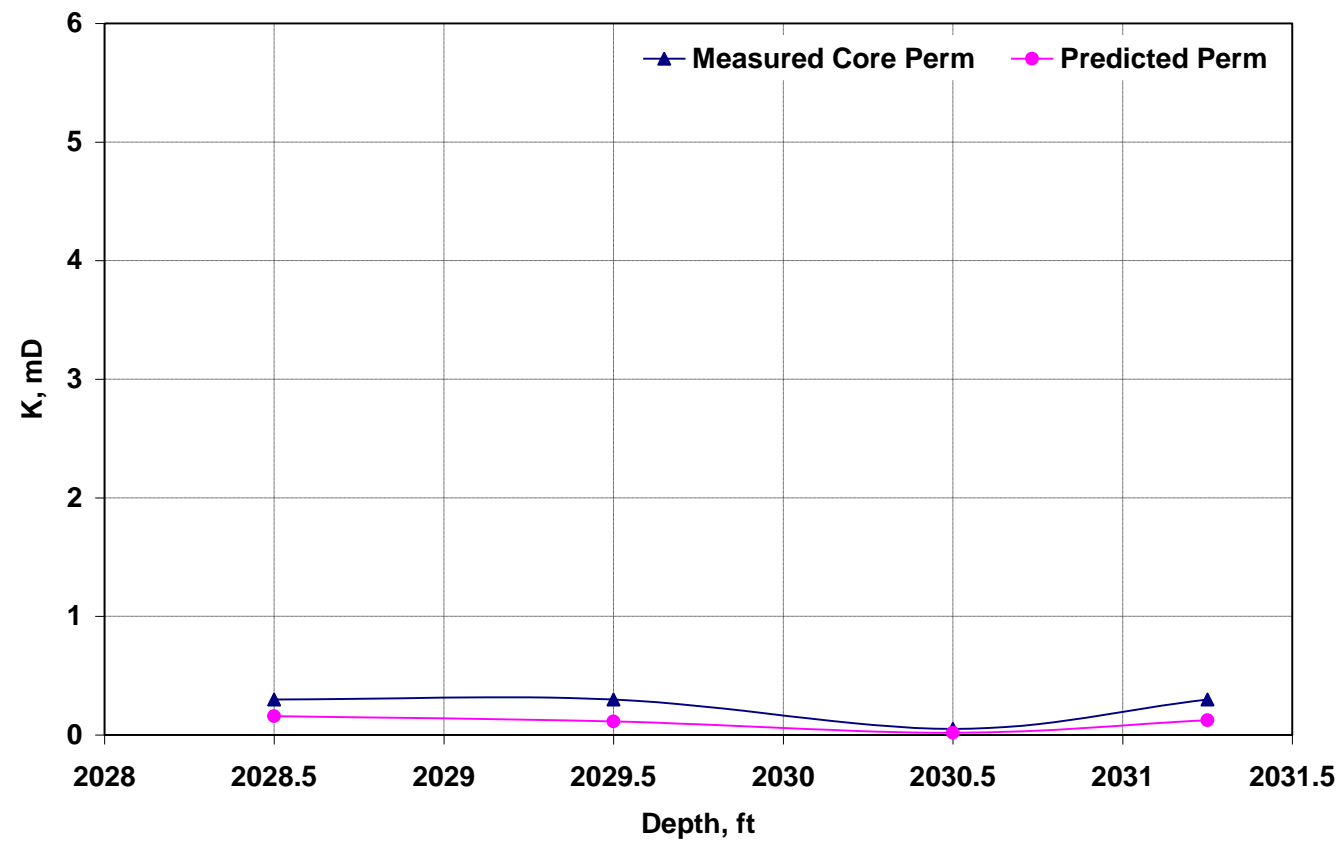

Figure B. 4 Permeability prediction for well 15-1059. 


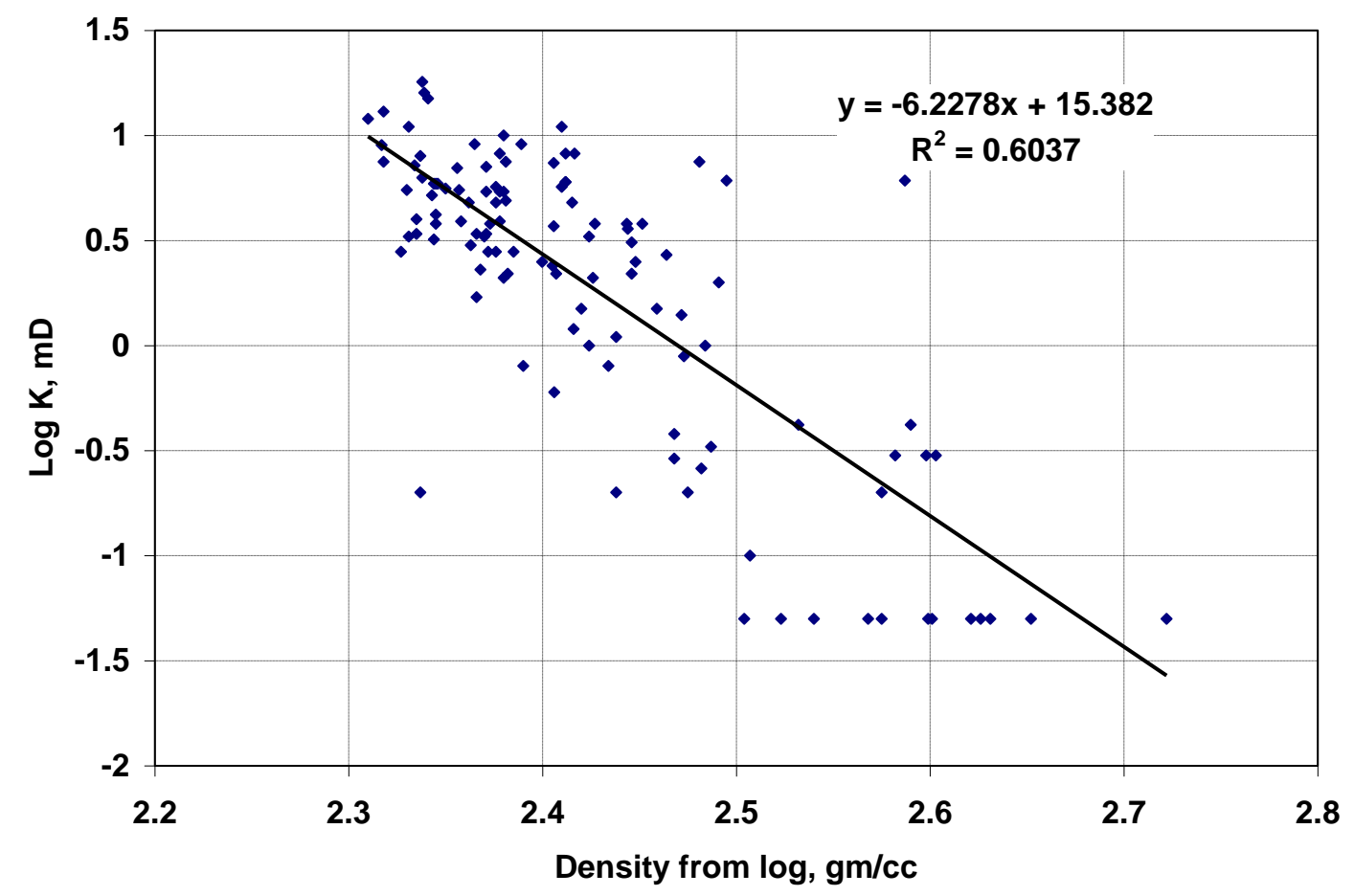

Figure B.5 Linear correlation between density from well log and logarithm of core permeability from Test 3 (except 15-1107).

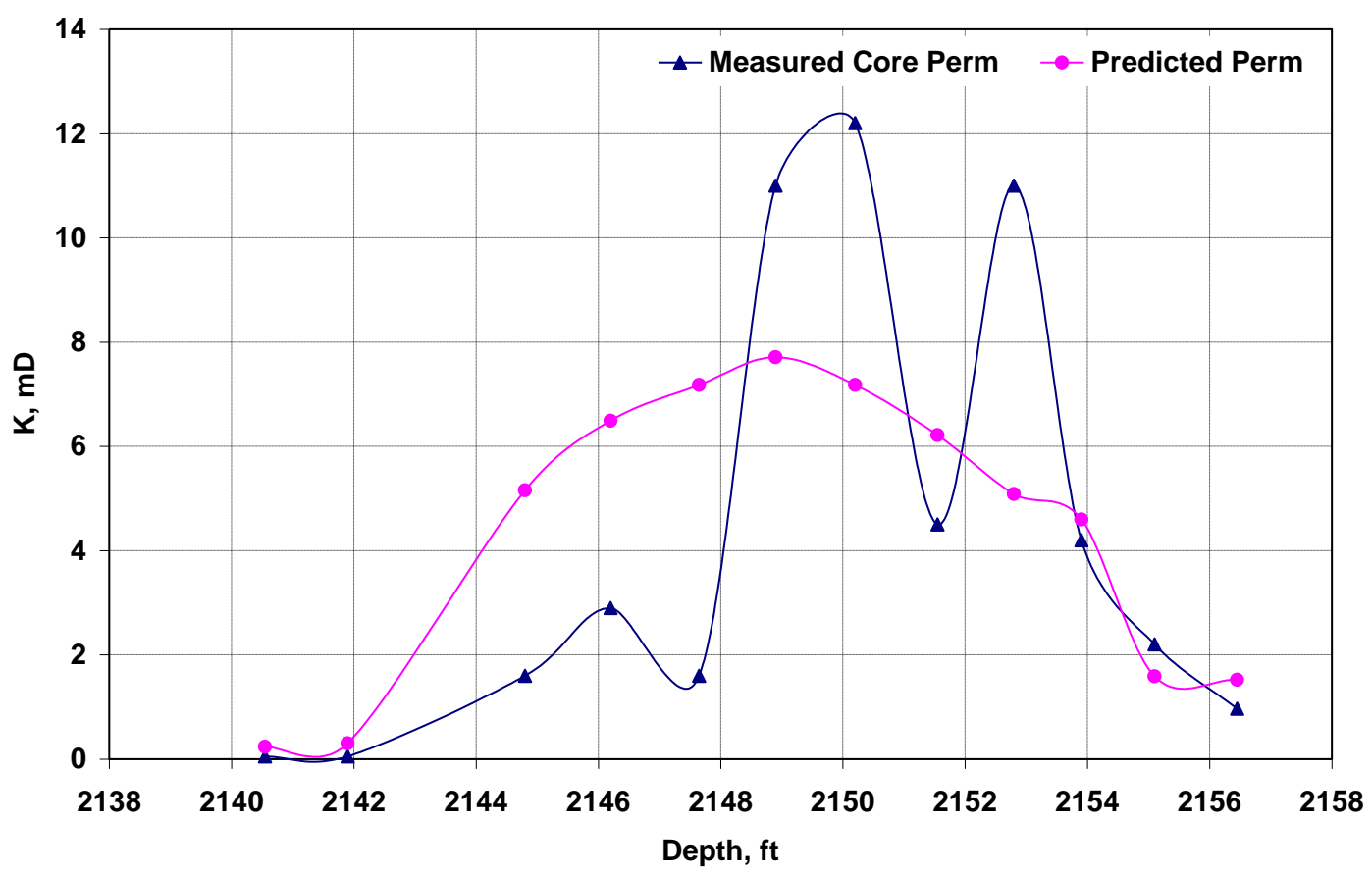

Figure B. 6 Permeability prediction for well 15-1107. 


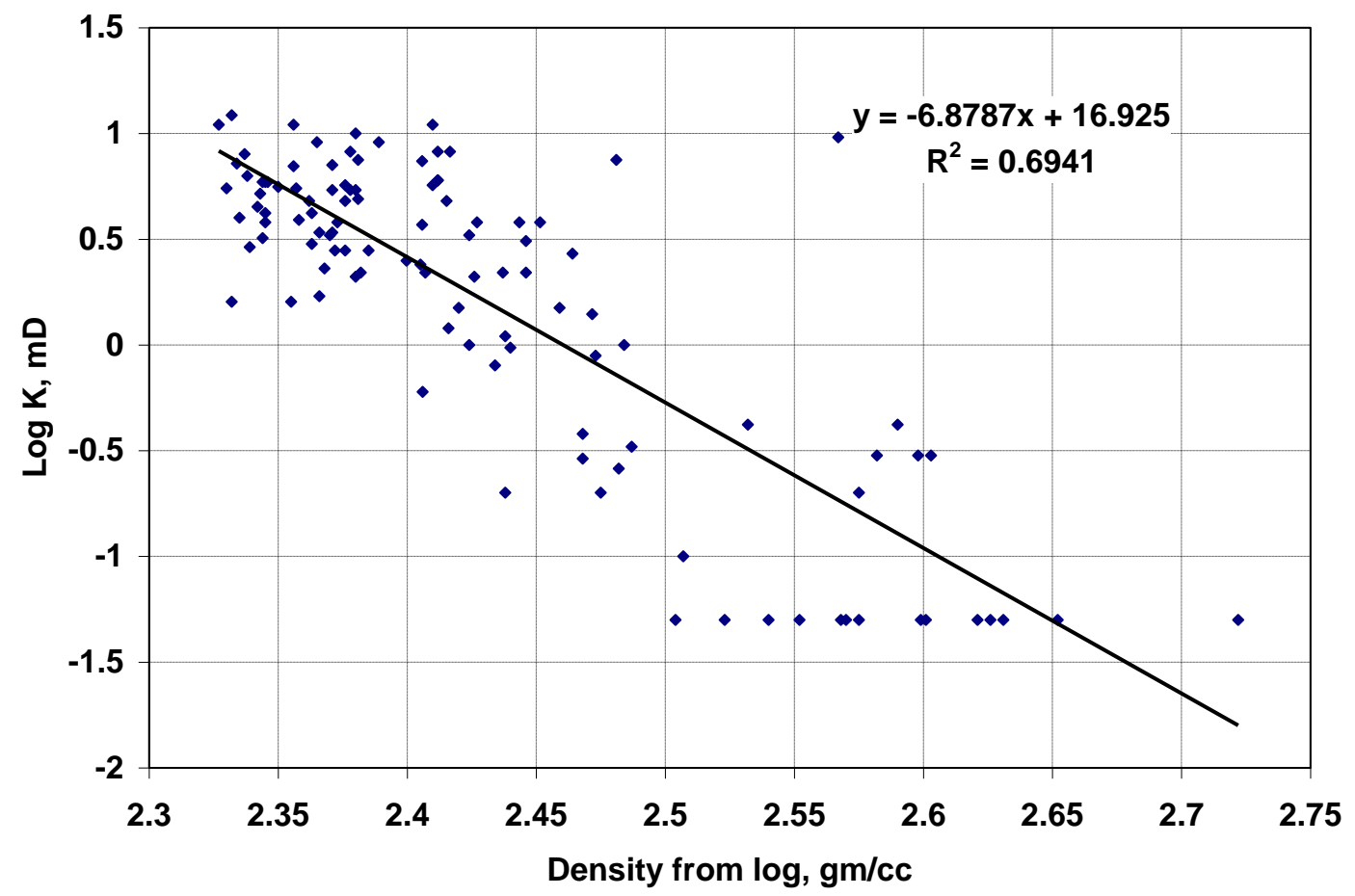

Figure B.7 Linear correlation between density from well log and logarithm of core permeability from Test 4 (except 15-1108).

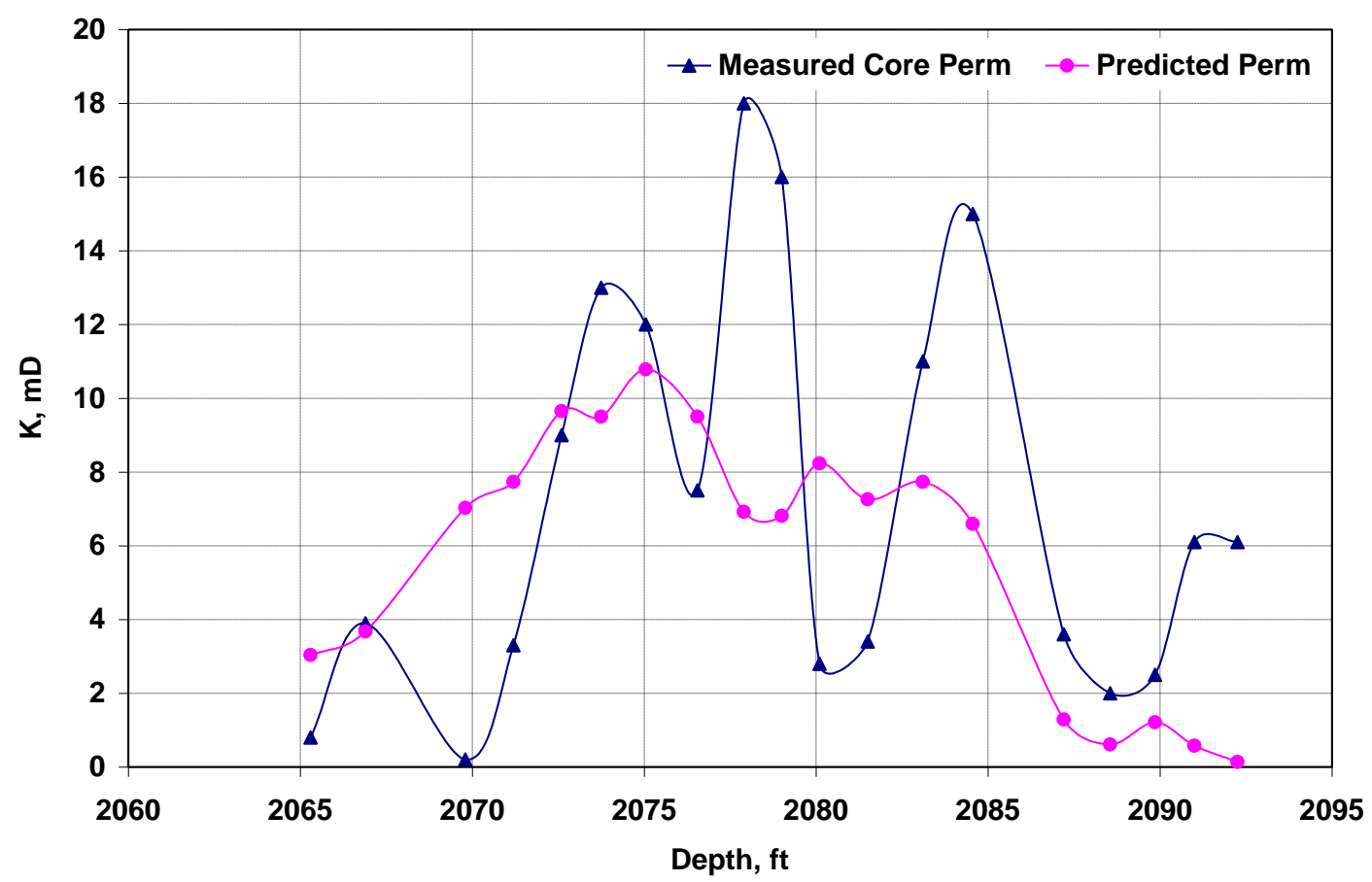

Figure B . 8 Permeability prediction for well 15-1108. 


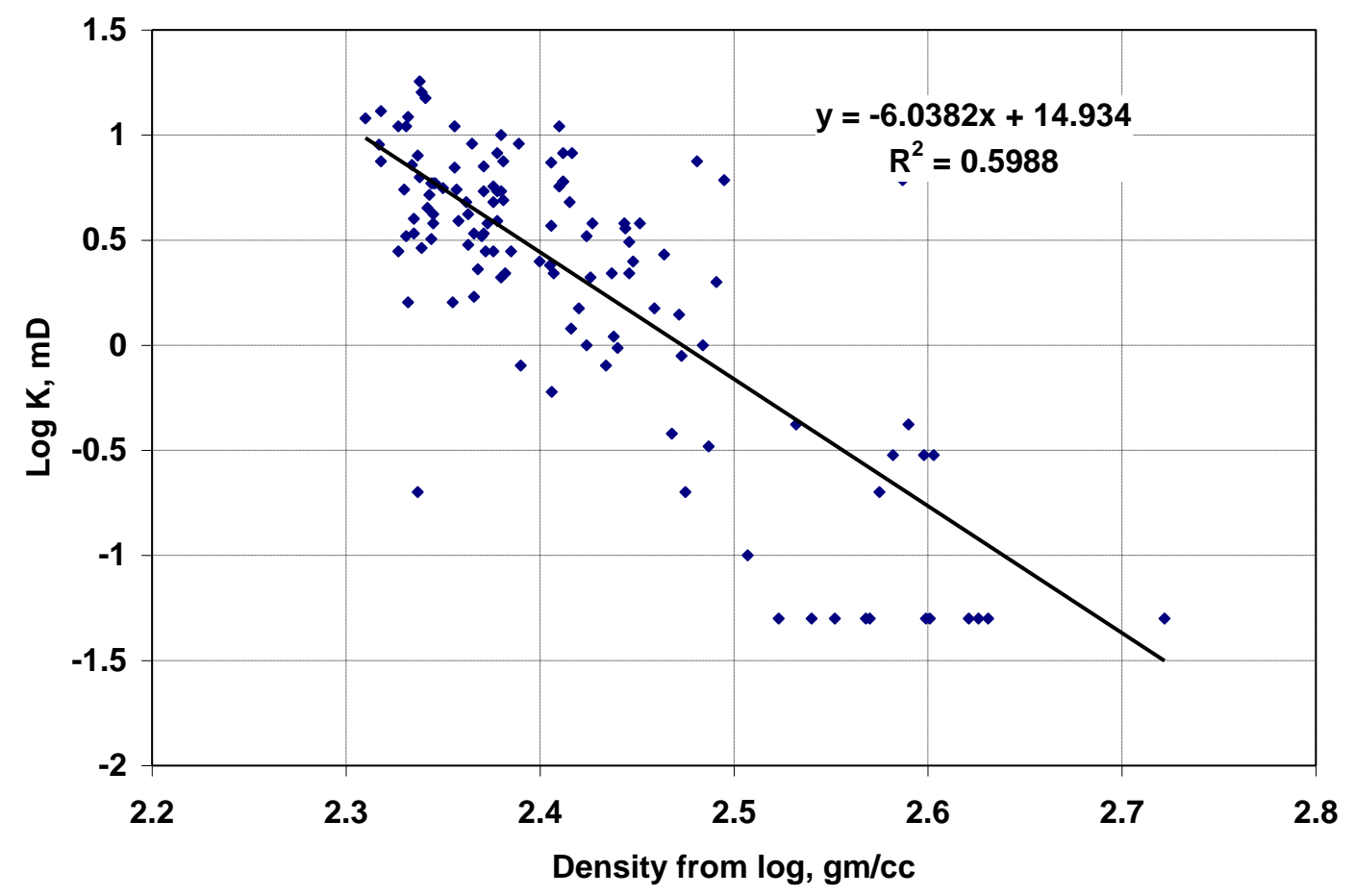

Figure B.9 Linear correlation between density from well log and logarithm of core permeability from Test 5 (except 15-1109).

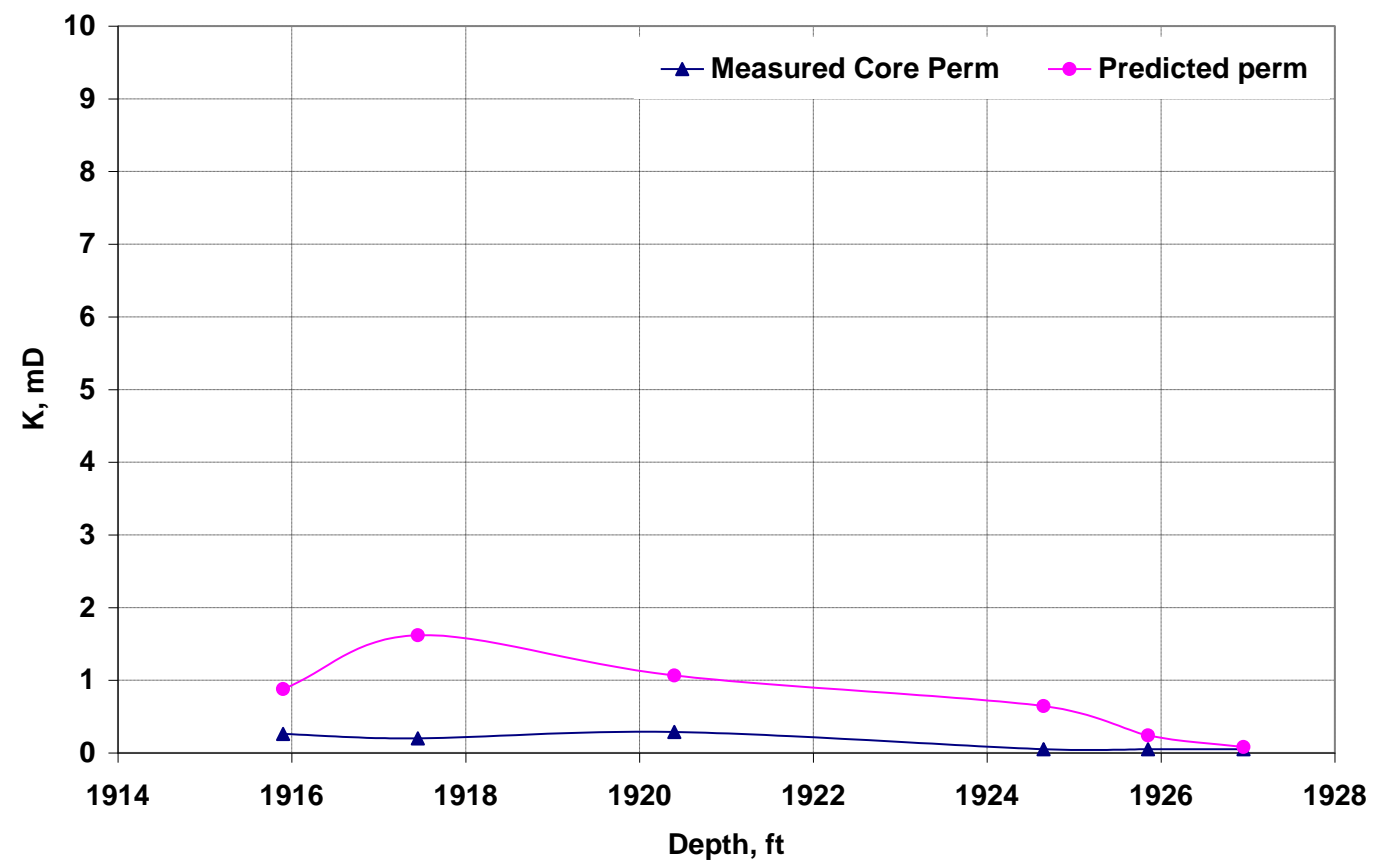

Figure B. 10 Permeability prediction for well 15-1109. 


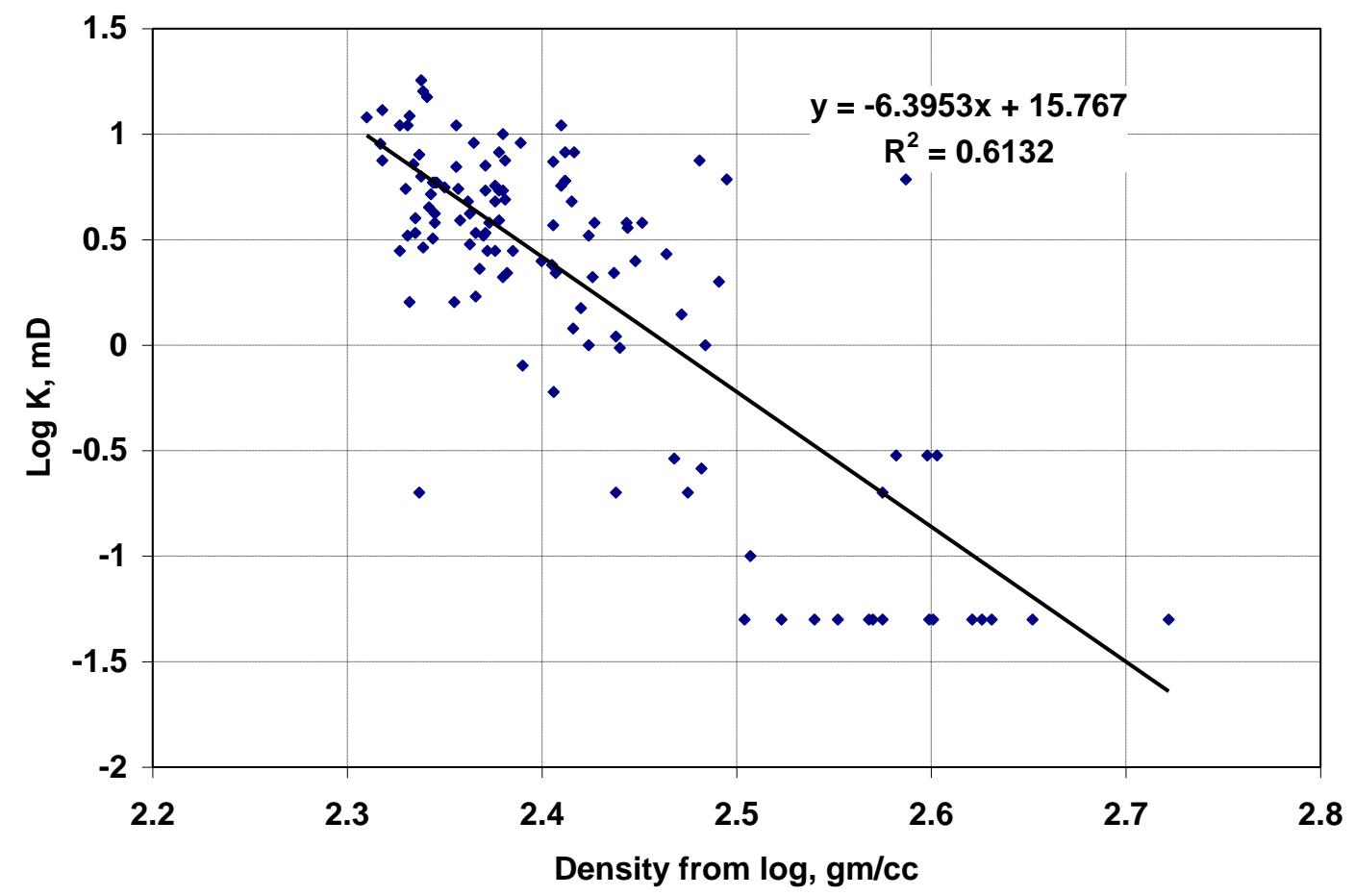

Figure B.11 L inear correlation between density from well log and logarithm of core permeability from Test 6 (except 15-1128).

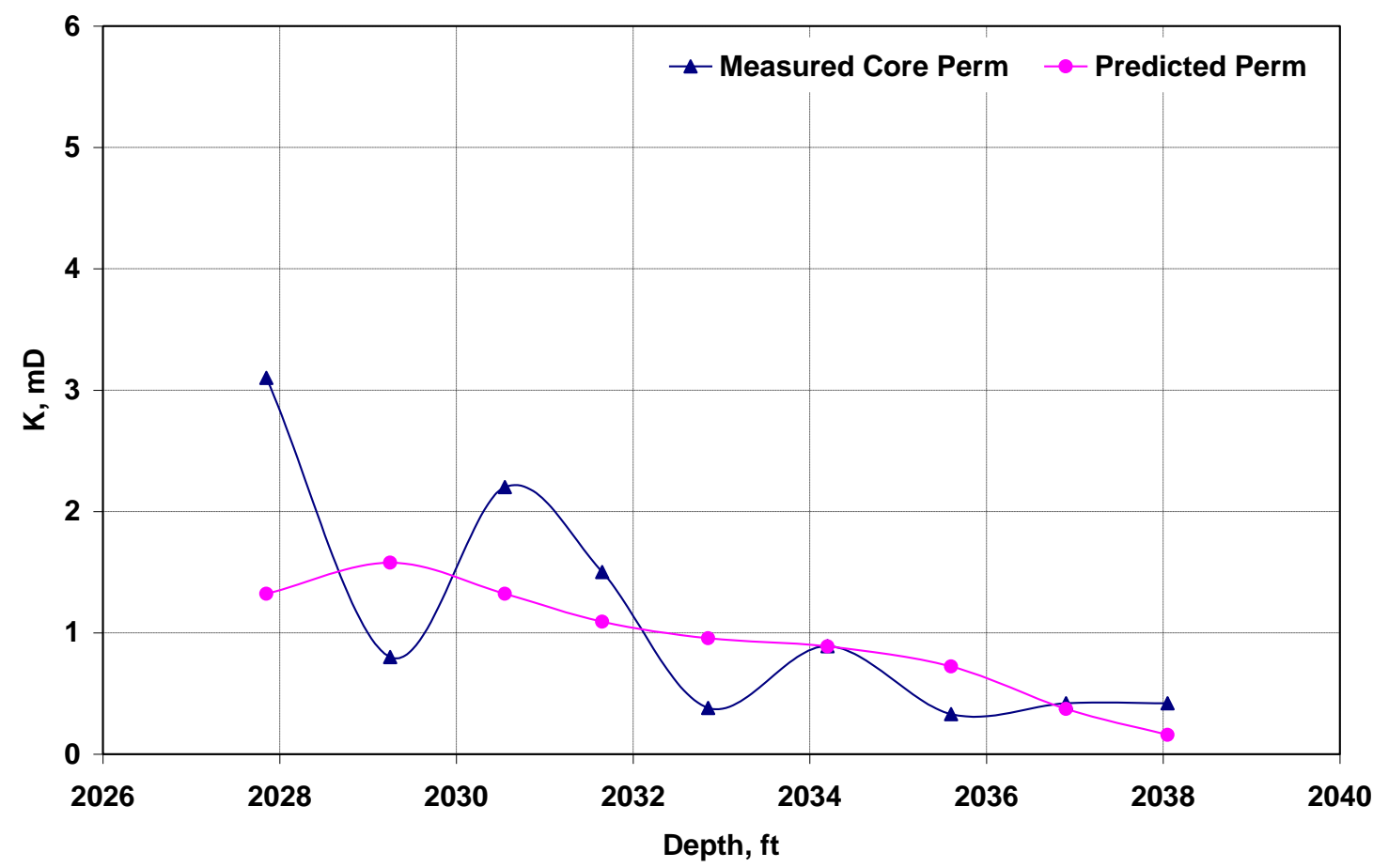

Figure B. 12 Permeability prediction for well 15-1128. 


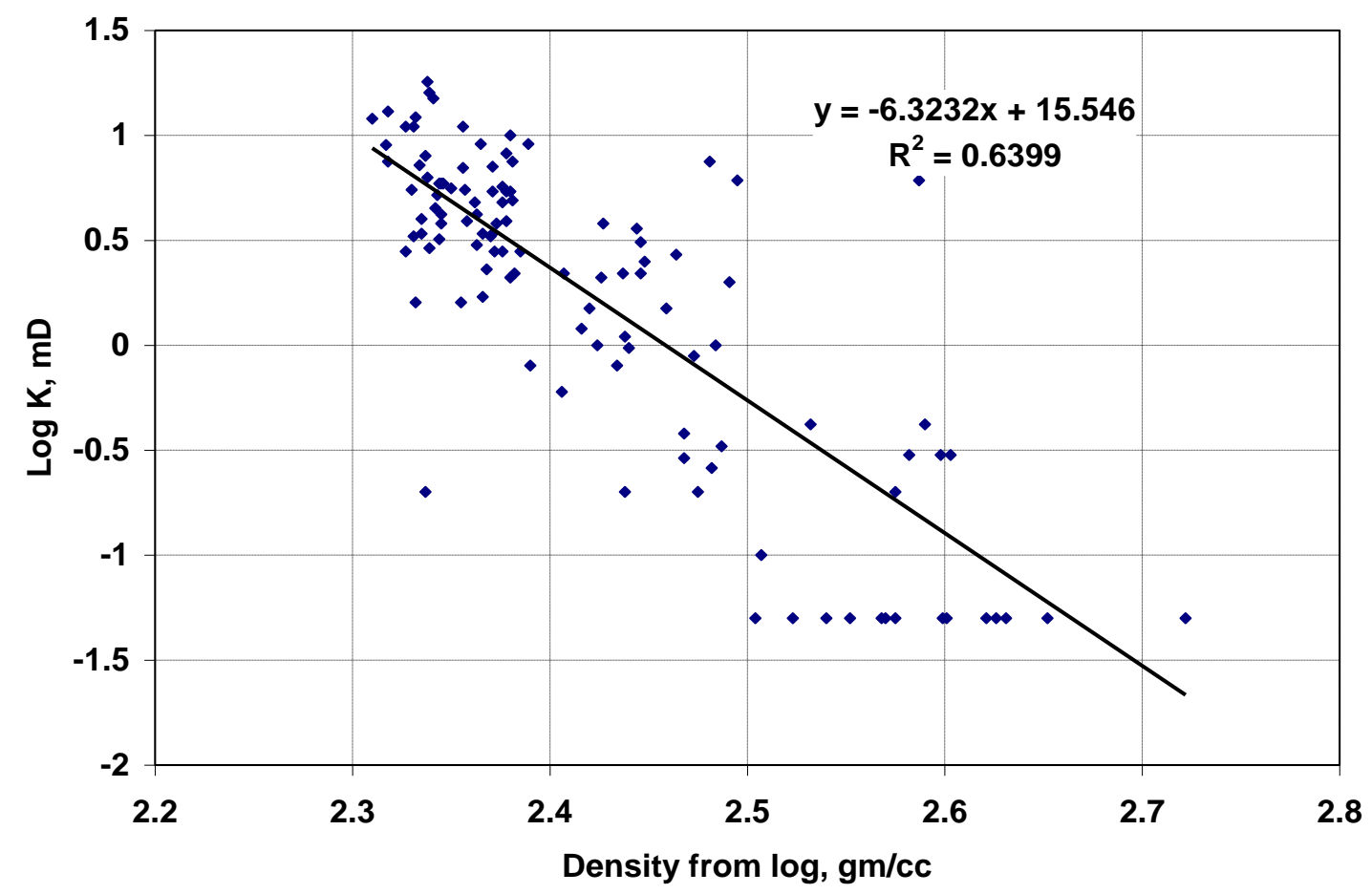

Figure B.13 L inear correlation between density from well log and logarithm of core permeability from Test 7 (except 15-1130).

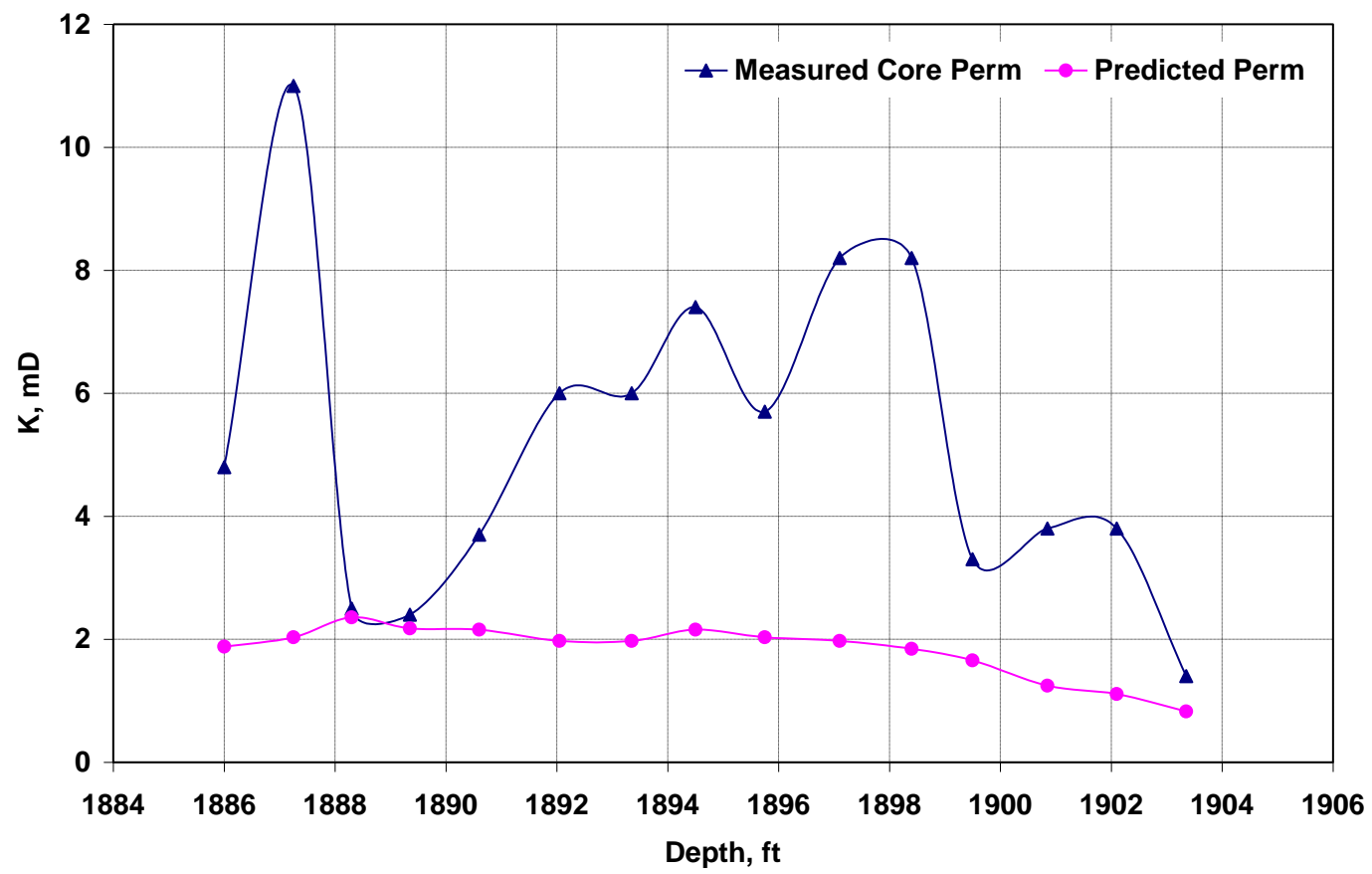

Figure B. 14 Permeability prediction for well 15-1130. 


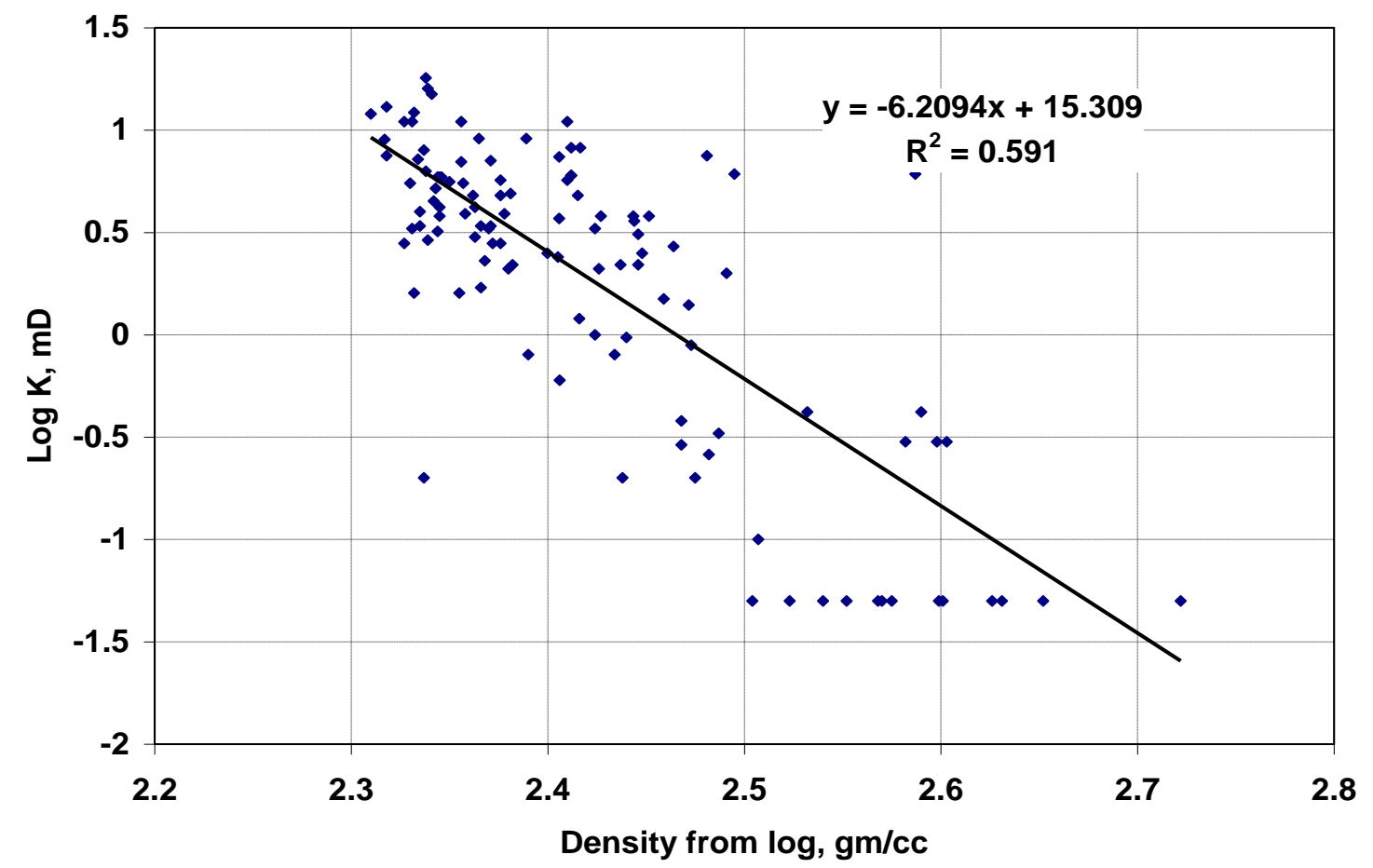

Figure B.15 L inear correlation between density from well log and logarithm of core permeability from Test 8 (except 15-1132).

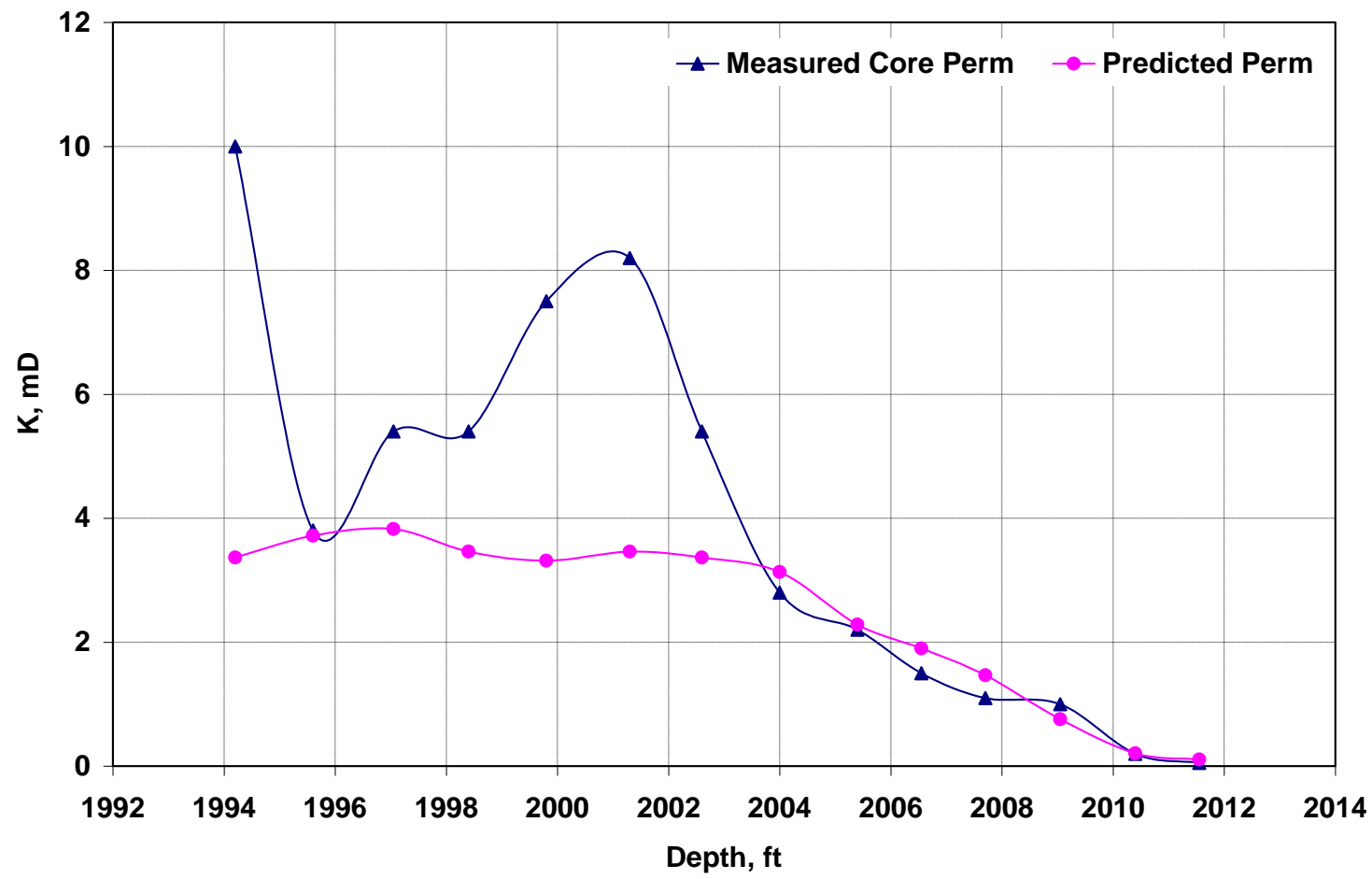

Figure B. 16 Permeability prediction for well 15-1132. 


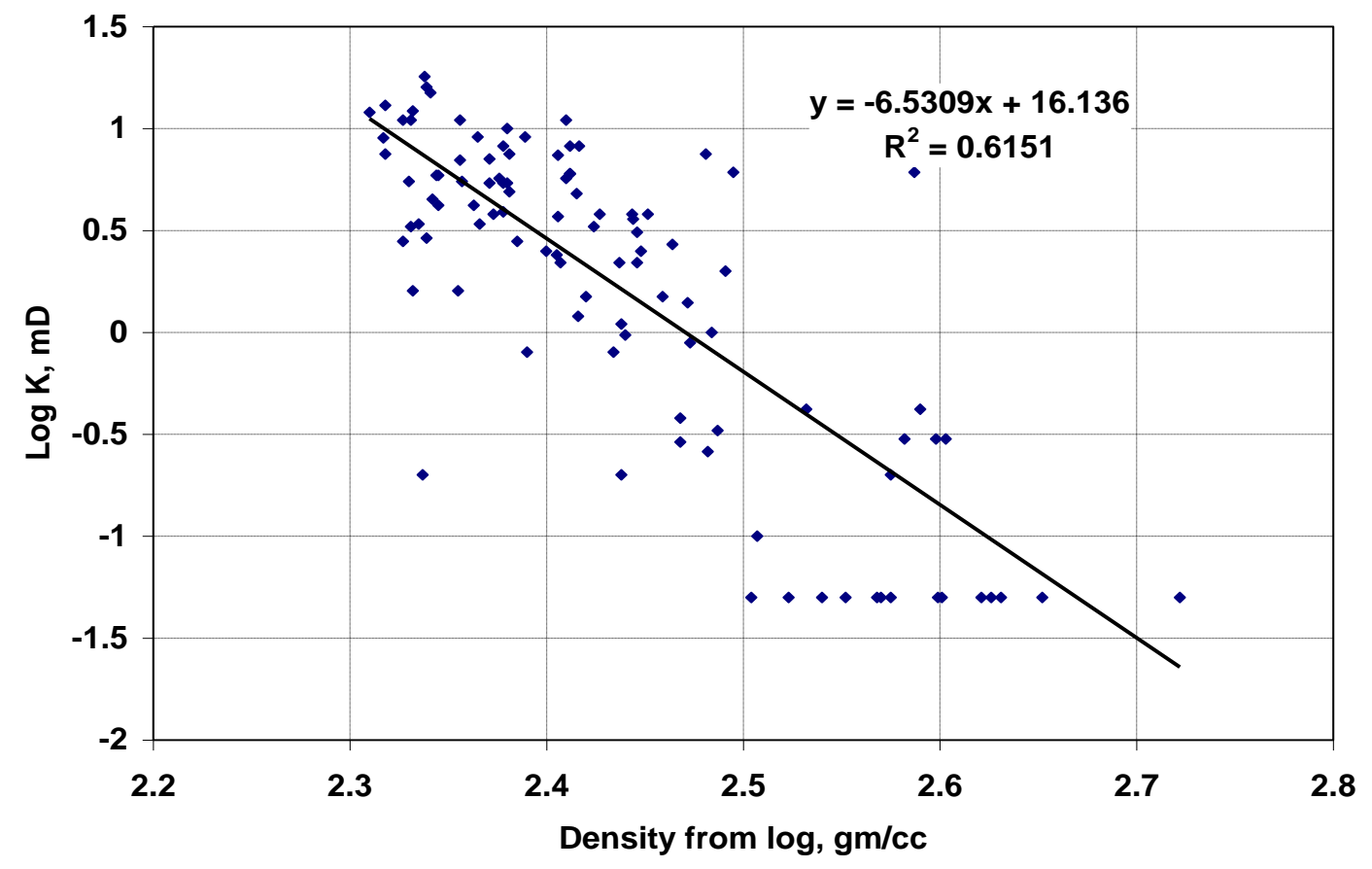

Figure B.17 Linear correlation between density from well log and logarithm of core permeability from Test 9 (except 15-1184).

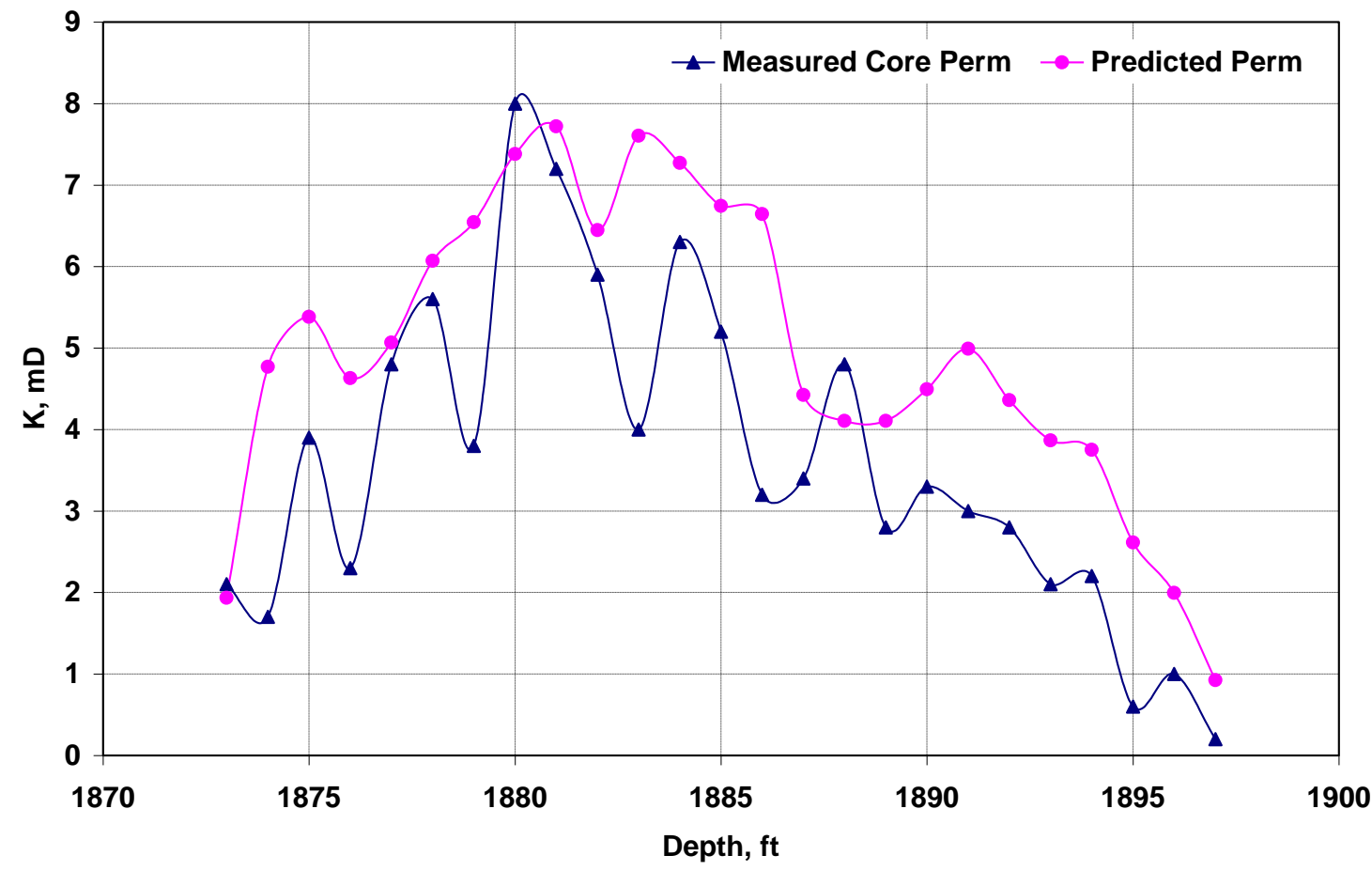

Figure B. 18 Permeability prediction for well 15-1184. 


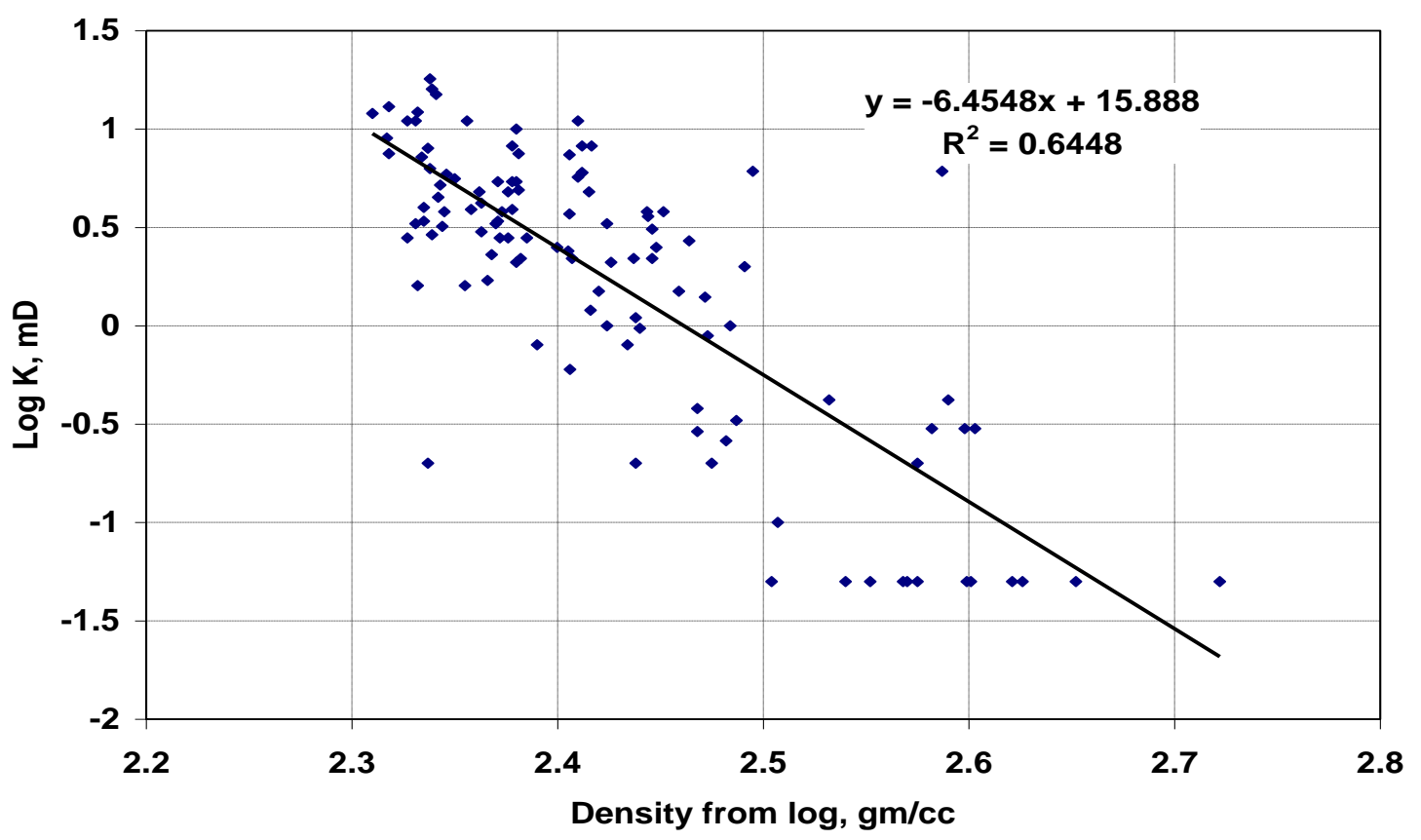

Figure B.19 L inear correlation between density from well log and logarithm of core permeability from Test 10 (except 15-1309).

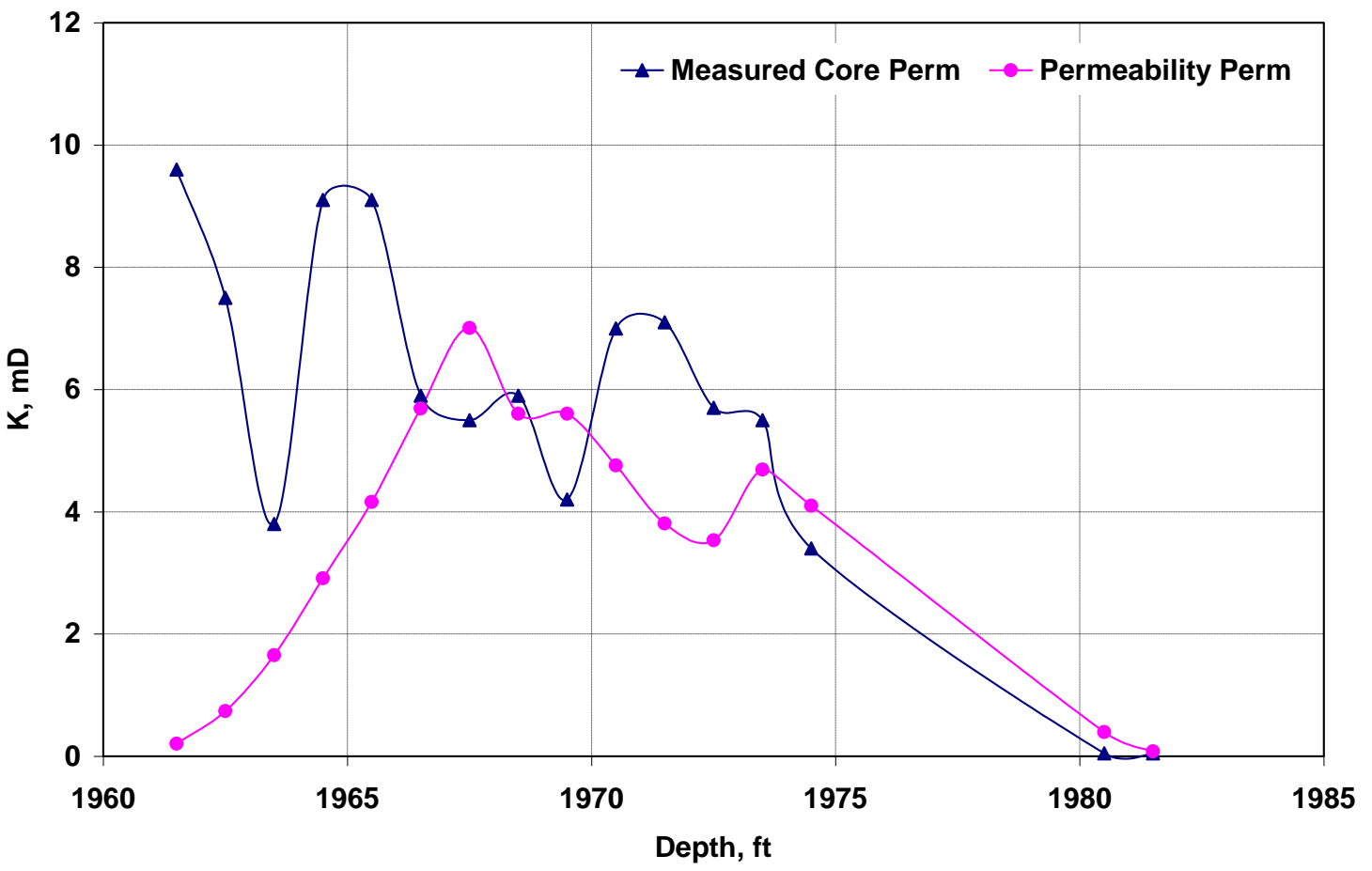

Figure B. 20 Permeability prediction for well 15-1309. 


\section{APPENDIX C. \\ Determination of Flow Unit by Statistical Z onation Technique using core permeability.}


Table C. 1 Flow U nit calculation for well 15-733 into two zones.

\begin{tabular}{|c|c|c|c|c|c|c|c|}
\hline $\begin{array}{l}\text { Sample } \\
\text { No.per } \\
\text { Group }\end{array}$ & $\begin{array}{c}\text { Core } \\
\text { Depth, Ft }\end{array}$ & $\mathrm{K}, \mathrm{mD}$ & $\begin{array}{c}\text { Cum.Sum of } K \text {, } \\
\mathrm{mD}\end{array}$ & $\begin{array}{c}\text { Grand Sum } \\
\text { M inus C um. } \\
\text { Sum, mD }\end{array}$ & $B, m D^{2}$ & $\mathrm{~W}, \mathrm{mD}^{2}$ & $\begin{array}{l}\text { Zonation } \\
\text { Index, R }\end{array}$ \\
\hline 1 & 2085.5 & 4.9 & 4.9 & 4.25 & 16.965 & 0.928 & 0.9453 \\
\hline 2 & 2086.5 & 1.2 & 6.1 & 3.05 & 10.631 & 1.833 & 0.8276 \\
\hline 3 & 2087.5 & 2.7 & 8.8 & 0.35 & 16.531 & 0.990 & 0.9463 \\
\hline$* *$ & ** & ** & ** & ** & $* *$ & ** & ** \\
\hline 4 & 2088.5 & 0.1 & 8.9 & 0.25 & 10.513 & 1.850 & 0.8241 \\
\hline 5 & 2089.5 & 0.05 & 8.95 & 0.2 & 6.728 & 2.390 & 0.6447 \\
\hline 6 & 2090.5 & 0.05 & 9 & 0.15 & 4.205 & 2.751 & 0.3458 \\
\hline 7 & 2091.5 & 0.05 & 9.05 & 0.1 & 2.403 & 3.008 & 0 \\
\hline 8 & 2092.3 & 0.05 & 9.1 & 0.05 & 1.051 & 3.201 & 0 \\
\hline 9 & 2096.5 & 0.05 & 9.15 & 0 & -- & -- & -- \\
\hline
\end{tabular}

Table C . 2 Flow U nit calculation for well 15-733 into three zones.

\begin{tabular}{|c|c|c|c|c|c|c|c|}
\hline $\begin{array}{l}\text { Sample } \\
\text { No.per } \\
\text { Group }\end{array}$ & $\begin{array}{c}\text { Core } \\
\text { Depth, Ft }\end{array}$ & $\mathrm{K}, \mathrm{mD}$ & $\underset{\mathrm{mD}}{\text { Cum.Sum of } K,}$ & $\begin{array}{c}\text { Grand Sum } \\
\text { Minus Cum. } \\
\text { Sum, mD }\end{array}$ & $B, m D^{2}$ & $\mathrm{~W}, \mathrm{mD}^{2}$ & $\begin{array}{l}\text { Zonation } \\
\text { Index, R }\end{array}$ \\
\hline \multicolumn{8}{|l|}{ Group 1} \\
\hline 1 & 2085.5 & 4.9 & 4.9 & 3.9 & 11.166 & 0.188 & 0.9832 \\
\hline ** & $* *$ & $* *$ & $* *$ & $* *$ & $* *$ & ** & $* *$ \\
\hline 2 & 2086.5 & 1.2 & 6.1 & 2.7 & 8.306 & 1.141 & 0.8626 \\
\hline 3 & 2087.5 & 2.7 & 8.8 & 0 & -- & -- & -- \\
\hline \multicolumn{8}{|l|}{ Group 2} \\
\hline 1 & 2088.5 & 0.1 & 0.1 & 0.25 & 8.267 & 1.154 & 0.8603 \\
\hline 2 & 2089.5 & 0.05 & 0.15 & 0.2 & 8.266 & 1.155 & 0.8603 \\
\hline 3 & 2090.5 & 0.05 & 0.2 & 0.15 & 8.266 & 1.155 & 0.8603 \\
\hline 4 & 2091.5 & 0.05 & 0.25 & 0.1 & 8.266 & 1.155 & 0.8603 \\
\hline 5 & 2092.3 & 0.05 & 0.3 & 0.05 & 8.266 & 1.155 & 0.8603 \\
\hline 6 & 2096.5 & 0.05 & 0.35 & 0 & -- & -- & -- \\
\hline
\end{tabular}


Table C . 3 Flow Unit calculation for well 15-1059 into two zones.

\begin{tabular}{cccccccc}
$\begin{array}{c}\text { Sample } \\
\text { No.per } \\
\text { Group }\end{array}$ & $\begin{array}{c}\text { Core } \\
\text { Depth, } \\
\text { Ft }\end{array}$ & K, mD & $\begin{array}{c}\text { Cum.Sum of K, } \\
\text { mD }\end{array}$ & $\begin{array}{c}\text { Grand Sum Minus } \\
\text { Cum. Sum, mD }\end{array}$ & B, mD $\mathbf{~}^{2}$ & W, mD $\mathbf{m b}^{2}$ & $\begin{array}{l}\text { Zonation } \\
\text { Index, R }\end{array}$ \\
\hline 1 & 2028.5 & 0.3 & 0.3 & 0.65 & 0.005 & 0.021 & 0 \\
2 & 2029.5 & 0.3 & 0.6 & 0.35 & 0.016 & 0.016 & 0 \\
3 & 2030.5 & 0.05 & 0.65 & 0.3 & 0.005 & 0.021 & 0 \\
4 & 2031.25 & 0.3 & 0.95 & 0 & -- & -- & --
\end{tabular}

Table C . 4 Flow Unit calculation for well 15-1107 into two zones.

\begin{tabular}{|c|c|c|c|c|c|c|c|}
\hline $\begin{array}{c}\text { Sample } \\
\text { No. per } \\
\text { Group }\end{array}$ & $\begin{array}{c}\text { Core } \\
\text { Depth, } \\
\text { Ft }\end{array}$ & $\mathrm{K}, \mathrm{mD}$ & $\begin{array}{c}\text { Cum.Sum of } K, \\
\mathrm{mD}\end{array}$ & $\begin{array}{l}\text { Grand Sum Minus } \\
\text { C um. Sum, mD }\end{array}$ & $B, m D^{2}$ & $\mathrm{~W}, \mathrm{mD}^{2}$ & $\begin{array}{l}\text { Zonation } \\
\text { Index, R }\end{array}$ \\
\hline 1 & 2140.55 & 0.05 & 0.05 & 52.22 & 20.226 & 20.014 & 0.0105 \\
\hline 2 & 2141.9 & 0.05 & 0.1 & 52.17 & 44.496 & 17.587 & 0.6048 \\
\hline 3 & 2144.8 & 1.6 & 1.7 & 50.57 & 57.431 & 16.294 & 0.7163 \\
\hline 4 & 2146.2 & 2.9 & 4.6 & 47.67 & 61.664 & 15.870 & 0.7426 \\
\hline 5 & 2147.65 & 1.6 & 6.2 & 46.07 & 83.215 & 13.715 & 0.8352 \\
\hline$* *$ & $* *$ & $* *$ & $* *$ & $* *$ & $* *$ & $* *$ & $* *$ \\
\hline 6 & 2148.9 & 11 & 17.2 & 35.07 & 26.611 & 19.376 & 0.2719 \\
\hline 7 & 2150.2 & 12.2 & 29.4 & 22.87 & 0.408 & 21.996 & 0 \\
\hline 8 & 2151.55 & 4.5 & 33.9 & 18.37 & 0.336 & 22.003 & 0 \\
\hline 9 & 2152.8 & 11 & 44.9 & 7.37 & 14.427 & 20.594 & 0 \\
\hline 10 & 2153.9 & 4.2 & 49.1 & 3.17 & 18.426 & 20.194 & 0 \\
\hline 11 & 2155.1 & 2.2 & 51.3 & 0.97 & 12.506 & 20.786 & 0 \\
\hline 12 & 2156.45 & 0.97 & 52.27 & 0 & -- & -- & -- \\
\hline
\end{tabular}


Table C . 5 Flow Unit calculation for well 15-1107 into three zones.

\begin{tabular}{|c|c|c|c|c|c|c|c|}
\hline $\begin{array}{c}\text { Sample } \\
\text { No. per } \\
\text { Group }\end{array}$ & $\begin{array}{c}\text { Core } \\
\text { Depth, } \\
\text { Ft }\end{array}$ & $\mathrm{K}, \mathrm{mD}$ & $\begin{array}{c}\text { Cum.Sum of } K, \\
\mathrm{mD}\end{array}$ & $\begin{array}{l}\text { Grand Sum M inus } \\
\text { Cum. Sum, mD }\end{array}$ & $B, m^{2}$ & $\mathrm{~W}, \mathrm{mD}^{2}$ & $\begin{array}{l}\text { Zonation } \\
\text { Index, R }\end{array}$ \\
\hline \multicolumn{8}{|l|}{ Group 1} \\
\hline 1 & 2140.55 & 0.05 & 0.05 & 6.15 & 42.493 & 15.042 & 0.6460 \\
\hline 2 & 2141.9 & 0.05 & 0.1 & 6.1 & 43.968 & 14.715 & 0.6653 \\
\hline 3 & 2144.8 & 1.6 & 1.7 & 4.5 & 43.308 & 14.861 & 0.6568 \\
\hline 4 & 2146.2 & 2.9 & 4.6 & 1.6 & 41.689 & 15.221 & 0.6349 \\
\hline 5 & 2147.65 & 1.6 & 6.2 & 0 & -- & -- & -- \\
\hline \multicolumn{8}{|l|}{ Group 2} \\
\hline 1 & 2148.9 & 11 & 11 & 35.07 & 52.996 & 12.708 & 0.7602 \\
\hline 2 & 2150.2 & 12.2 & 23.2 & 22.87 & 76.868 & 7.403 & 0.9037 \\
\hline 3 & 2151.55 & 4.5 & 27.7 & 18.37 & 60.068 & 11.137 & 0.8146 \\
\hline 4 & 2152.8 & 11 & 38.7 & 7.37 & 86.268 & 5.314 & 0.9384 \\
\hline$* *$ & $* *$ & $* *$ & $* *$ & $* *$ & $* *$ & $* *$ & $* *$ \\
\hline 5 & 2153.9 & 4.2 & 42.9 & 3.17 & 76.558 & 7.472 & 0.9024 \\
\hline 6 & 2155.1 & 2.2 & 45.1 & 0.97 & 59.976 & 11.157 & 0.8140 \\
\hline 7 & 2156.45 & 0.97 & 46.07 & 0 & -- & -- & -- \\
\hline
\end{tabular}

Table C . 6 F low U nit calculation for well 15-1107 into four zones.

\begin{tabular}{|c|c|c|c|c|c|c|c|}
\hline $\begin{array}{c}\text { Sample } \\
\text { No. per } \\
\text { Group }\end{array}$ & $\begin{array}{c}\text { Core } \\
\text { Depth, } \\
\text { Ft }\end{array}$ & $K, m D$ & $\begin{array}{c}\text { Cum.Sum of } K, \\
\mathrm{mD}\end{array}$ & $\begin{array}{l}\text { Grand Sum Minus } \\
\text { C um. Sum, mD }\end{array}$ & $B, m D^{2}$ & $\mathrm{~W}, \mathrm{mD}^{2}$ & $\begin{array}{l}\text { Zonation } \\
\text { Index, R }\end{array}$ \\
\hline \multicolumn{8}{|l|}{ Group 1} \\
\hline 1 & 2140.55 & 0.05 & 0.05 & 6.15 & 42.493 & 15.042 & 0.6460 \\
\hline 2 & 2141.9 & 0.05 & 0.1 & 6.1 & 43.968 & 14.715 & 0.6653 \\
\hline 3 & 2144.8 & 1.6 & 1.7 & 4.5 & 43.308 & 14.861 & 0.6568 \\
\hline 4 & 2146.2 & 2.9 & 4.6 & 1.6 & 41.689 & 15.221 & 0.6349 \\
\hline 5 & 2147.65 & 1.6 & 6.2 & 0 & -- & -- & -- \\
\hline \multicolumn{8}{|l|}{ Group 2} \\
\hline 1 & 2148.9 & 11 & 11 & 35.07 & 83.595 & 13.294 & 0.8410 \\
\hline 2 & 2150.2 & 12.2 & 23.2 & 22.87 & 89.836 & 10.174 & 0.8868 \\
\hline 3 & 2151.55 & 4.5 & 27.7 & 18.37 & 83.595 & 13.294 & 0.8410 \\
\hline 4 & 2152.8 & 11 & 38.7 & 7.37 & -- & -- & -- \\
\hline \multicolumn{8}{|l|}{ Group 3} \\
\hline 1 & 2153.9 & 4.2 & 42.9 & 3.17 & 84.704 & 5.662 & 0.9332 \\
\hline 2 & 2155.1 & 2.2 & 45.1 & 0.97 & 84.082 & 5.800 & 0.9310 \\
\hline 3 & 2156.45 & 0.97 & 46.07 & 0 & -- & -- & -- \\
\hline
\end{tabular}


Table C . 7 Flow Unit calculation for well 15-1108 into two zones.

\begin{tabular}{|c|c|c|c|c|c|c|c|}
\hline $\begin{array}{l}\text { Sample } \\
\text { No. per } \\
\text { Group }\end{array}$ & $\begin{array}{c}\text { Core } \\
\text { Depth, } \\
\text { Ft }\end{array}$ & $K, \mathrm{mD}$ & $\begin{array}{c}\text { Cum.Sum of } K \text {, } \\
\text { mD }\end{array}$ & $\begin{array}{l}\text { G rand Sum M inus } \\
\text { Cum. Sum, mD }\end{array}$ & $B, m^{2}$ & $\mathbf{W}, \mathrm{mD}^{2}$ & Zonation Index, R \\
\hline 1 & 2065.3 & 0.8 & 0.8 & 135.4 & 42.810 & 29.465 & 0.3117 \\
\hline 2 & 2066.9 & 3.9 & 4.7 & 131.5 & 51.897 & 28.931 & 0.4425 \\
\hline 3 & 2069.8 & 0.2 & 4.9 & 131.3 & 109.145 & 25.563 & 0.7658 \\
\hline 4 & 2071.2 & 3.3 & 8.2 & 128 & 132.738 & 24.175 & 0.8179 \\
\hline$* *$ & $* *$ & $* *$ & $* *$ & $* *$ & $* *$ & $* *$ & $* *$ \\
\hline 5 & 2072.6 & 9 & 17.2 & 119 & 94.329 & 26.435 & 0.7198 \\
\hline 6 & 2073.75 & 13 & 30.2 & 106 & 39.975 & 29.632 & 0.2587 \\
\hline 7 & 2075.05 & 12 & 42.2 & 94 & 14.400 & 31.137 & 0 \\
\hline 8 & 2076.55 & 7.5 & 49.7 & 86.5 & 12.627 & 31.241 & 0 \\
\hline 9 & 2077.9 & 18 & 67.7 & 68.5 & 2.140 & 31.858 & 0 \\
\hline 10 & 2079 & 16 & 83.7 & 52.5 & 30.480 & 30.191 & 0.0095 \\
\hline 11 & 2080.1 & 2.8 & 86.5 & 49.7 & 12.627 & 31.241 & 0 \\
\hline 12 & 2081.5 & 3.4 & 89.9 & 46.3 & 3.403 & 31.783 & 0 \\
\hline 13 & 2083.1 & 11 & 100.9 & 35.3 & 14.482 & 31.132 & 0 \\
\hline 14 & 2084.55 & 15 & 115.9 & 20.3 & 65.565 & 28.127 & 0.5710 \\
\hline 15 & 2087.2 & 3.6 & 119.5 & 16.7 & 45.400 & 29.313 & 0.3543 \\
\hline 16 & 2088.55 & 2 & 121.5 & 14.7 & 18.332 & 30.905 & 0 \\
\hline 17 & 2089.85 & 2.5 & 124 & 12.2 & 2.552 & 31.833 & 0 \\
\hline 18 & 2091 & 6.1 & 130.1 & 6.1 & 1.205 & 31.913 & 0 \\
\hline 19 & 2092.25 & 6.1 & 136.2 & 0 & -- & -- & -- \\
\hline
\end{tabular}


Table C . 8 Flow Unit calculation for well 15-1108 into three zones.

\begin{tabular}{|c|c|c|c|c|c|c|c|}
\hline $\begin{array}{l}\text { Sample } \\
\text { No. per } \\
\text { Group }\end{array}$ & $\begin{array}{c}\text { Core } \\
\text { Depth, } \\
\text { Ft }\end{array}$ & $\mathrm{K}, \mathrm{mD}$ & $\begin{array}{c}\text { Cum.Sum of } K, \\
\mathrm{mD}\end{array}$ & $\begin{array}{l}\text { Grand Sum M inus } \\
\text { Cum. Sum, mD }\end{array}$ & $B, m^{2}$ & $\mathrm{~W}, \mathrm{mD}^{2}$ & $\begin{array}{l}\text { Zonation } \\
\text { Index, R }\end{array}$ \\
\hline \multicolumn{8}{|l|}{ Group 1} \\
\hline 1 & 2065.3 & 0.8 & 0.8 & 7.4 & 67.411 & 25.556 & 0.6209 \\
\hline 2 & 2066.9 & 3.9 & 4.7 & 3.5 & 66.549 & 25.664 & 0.6144 \\
\hline 3 & 2069.8 & 0.2 & 4.9 & 3.3 & 67.411 & 25.556 & 0.6209 \\
\hline 4 & 2071.2 & 3.3 & 8.2 & 0 & -- & -- & -- \\
\hline \multicolumn{8}{|l|}{ Group 2} \\
\hline 1 & 2072.6 & 9 & 9 & 119 & 66.486 & 25.672 & 0.6139 \\
\hline 2 & 2073.75 & 13 & 22 & 106 & 73.389 & 24.809 & 0.6620 \\
\hline 3 & 2075.05 & 12 & 34 & 94 & 81.069 & 23.849 & 0.7058 \\
\hline 4 & 2076.55 & 7.5 & 41.5 & 86.5 & 75.619 & 24.530 & 0.6756 \\
\hline 5 & 2077.9 & 18 & 59.5 & 68.5 & 108.873 & 20.373 & 0.8129 \\
\hline 6 & 2079 & 16 & 75.5 & 52.5 & 148.381 & 15.435 & 0.8960 \\
\hline$* *$ & $* *$ & $* *$ & $* *$ & $* *$ & $* *$ & $* *$ & $* *$ \\
\hline 7 & 2080.1 & 2.8 & 78.3 & 49.7 & 112.537 & 19.915 & 0.8230 \\
\hline 8 & 2081.5 & 3.4 & 81.7 & 46.3 & 90.537 & 22.665 & 0.7497 \\
\hline 9 & 2083.1 & 11 & 92.7 & 35.3 & 101.481 & 21.297 & 0.7901 \\
\hline 10 & 2084.55 & 15 & 107.7 & 20.3 & 141.409 & 16.306 & 0.8847 \\
\hline 11 & 2087.2 & 3.6 & 111.3 & 16.7 & 118.174 & 19.211 & 0.8374 \\
\hline 12 & 2088.55 & 2 & 113.3 & 14.7 & 91.121 & 22.592 & 0.7521 \\
\hline 13 & 2089.85 & 2.5 & 115.8 & 12.2 & 73.201 & 24.832 & 0.6608 \\
\hline 14 & 2091 & 6.1 & 121.9 & 6.1 & 69.541 & 25.290 & 0.6363 \\
\hline 15 & 2092.25 & 6.1 & 128 & 0 & -- & -- & -- \\
\hline
\end{tabular}


Table C. 9 Flow U nit calculation for well 15-1108 into four zones.

\begin{tabular}{|c|c|c|c|c|c|c|c|}
\hline $\begin{array}{l}\text { Sample } \\
\text { No. per } \\
\text { Group }\end{array}$ & $\begin{array}{c}\text { Core } \\
\text { Depth, } \\
\text { Ft }\end{array}$ & $\mathrm{K}, \mathrm{mD}$ & $\begin{array}{c}\text { Cum.Sum of } K \text {, } \\
\mathrm{mD}\end{array}$ & $\begin{array}{l}\text { Grand Sum M inus } \\
\text { Cum. Sum, mD }\end{array}$ & $B, m D^{2}$ & $\mathrm{~W}, \mathrm{mD}^{2}$ & $\begin{array}{l}\text { Zonation } \\
\text { Index, R }\end{array}$ \\
\hline \multicolumn{8}{|l|}{ Group 1} \\
\hline 1 & 2065.3 & 0.8 & 0.8 & 7.4 & 67.411 & 25.556 & 0.6209 \\
\hline 2 & 2066.9 & 3.9 & 4.7 & 3.5 & 66.549 & 25.664 & 0.6144 \\
\hline 3 & 2069.8 & 0.2 & 4.9 & 3.3 & 67.411 & 25.556 & 0.6209 \\
\hline 4 & 2071.2 & 3.3 & 8.2 & 0 & -- & -- & -- \\
\hline \multicolumn{8}{|l|}{ Group 2} \\
\hline 1 & 2072.6 & 9 & 9 & 66.5 & 147.681 & 15.523 & 0.8949 \\
\hline 2 & 2073.75 & 13 & 22 & 53.5 & 143.737 & 16.015 & 0.8886 \\
\hline 3 & 2075.05 & 12 & 34 & 41.5 & 144.664 & 15.900 & 0.8901 \\
\hline 4 & 2076.55 & 7.5 & 41.5 & 34 & 169.237 & 12.828 & 0.9242 \\
\hline$* *$ & $* *$ & $* *$ & $* *$ & $* *$ & $* *$ & $* *$ & $* *$ \\
\hline 5 & 2077.9 & 18 & 59.5 & 16 & 146.981 & 15.610 & 0.8938 \\
\hline 6 & 2079 & 16 & 75.5 & 0 & -- & -- & -- \\
\hline \multicolumn{8}{|l|}{ Group 3} \\
\hline 1 & 2080.1 & 2.8 & 2.8 & 49.7 & 145.152 & 15.839 & 0.8909 \\
\hline 2 & 2081.5 & 3.4 & 6.2 & 46.3 & 149.582 & 15.285 & 0.8978 \\
\hline 3 & 2083.1 & 11 & 17.2 & 35.3 & 139.999 & 16.483 & 0.8823 \\
\hline 4 & 2084.55 & 15 & 32.2 & 20.3 & 157.665 & 14.274 & 0.9095 \\
\hline 5 & 2087.2 & 3.6 & 35.8 & 16.7 & 149.877 & 15.248 & 0.8983 \\
\hline 6 & 2088.55 & 2 & 37.8 & 14.7 & 141.936 & 16.241 & 0.8856 \\
\hline 7 & 2089.85 & 2.5 & 40.3 & 12.2 & 140.068 & 16.474 & 0.8824 \\
\hline 8 & 2091 & 6.1 & 46.4 & 6.1 & 140.016 & 16.481 & 0.8823 \\
\hline 9 & 2092.25 & 6.1 & 52.5 & 0 & -- & -- & -- \\
\hline
\end{tabular}


Table C. 10 Flow Unit calculation for well 15-1109 into two zones.

\begin{tabular}{|c|c|c|c|c|c|c|c|}
\hline $\begin{array}{l}\text { Sample } \\
\text { No. per } \\
\text { G roup }\end{array}$ & $\begin{array}{c}\text { Core } \\
\text { Depth, } \\
\text { Ft }\end{array}$ & $K, \mathrm{mD}$ & $\begin{array}{c}\text { C um.Sum of } K \text {, } \\
\mathrm{mD}\end{array}$ & $\begin{array}{l}\text { G rand Sum M inus } \\
\text { Cum. Sum, mD }\end{array}$ & $B, m^{2}$ & $\mathrm{~W}, \mathrm{mD}^{2}$ & $\begin{array}{l}\text { Zonation } \\
\text { Index, R }\end{array}$ \\
\hline 1 & 1915.9 & 0.26 & 0.26 & 0.64 & 0.015 & 0.012 & 0.1446 \\
\hline 2 & 1917.45 & 0.2 & 0.46 & 0.44 & 0.019 & 0.011 & 0.4141 \\
\hline 3 & 1920.4 & 0.29 & 0.75 & 0.15 & 0.060 & 0.001 & 0.9825 \\
\hline$* *$ & $* *$ & $* *$ & $* *$ & $* *$ & $* *$ & $* *$ & $* *$ \\
\hline 4 & 1924.65 & 0.05 & 0.8 & 0.1 & 0.030 & 0.009 & 0.7150 \\
\hline 5 & 1925.85 & 0.05 & 0.85 & 0.05 & 0.012 & 0.013 & 0 \\
\hline 6 & 1926.95 & 0.05 & 0.9 & 0 & -- & -- & -- \\
\hline
\end{tabular}

Table C. 11 Flow Unit calculation for well 15-1109 into three zones.

\begin{tabular}{|c|c|c|c|c|c|c|c|}
\hline $\begin{array}{c}\text { Sample } \\
\text { No. per } \\
\text { G roup }\end{array}$ & $\begin{array}{c}\text { Core } \\
\text { Depth, } \\
\text { Ft }\end{array}$ & $\mathrm{K}, \mathrm{mD}$ & $\begin{array}{c}\text { Cum.Sum of } K \text {, } \\
\text { mD }\end{array}$ & $\begin{array}{l}\text { Grand Sum M inus } \\
\text { Cum. Sum, mD }\end{array}$ & $B, m^{2}$ & $\mathrm{~W}, \mathrm{mD}^{2}$ & $\begin{array}{l}\text { Zonation } \\
\text { Index, R }\end{array}$ \\
\hline \multicolumn{8}{|l|}{ Group 1} \\
\hline 1 & 1915.9 & 0.26 & 0.26 & 0.49 & 0.030 & 0.001 & 0.9551 \\
\hline 2 & 1917.45 & 0.2 & 0.46 & 0.29 & 0.031 & 0.001 & 0.9808 \\
\hline 3 & 1920.4 & 0.29 & 0.75 & 0 & -- & -- & -- \\
\hline \multicolumn{8}{|l|}{ Group 2} \\
\hline 1 & 1924.65 & 0.05 & 0.8 & 0.1 & 0.030 & 0.001 & 0.9533 \\
\hline 2 & 1925.85 & 0.05 & 0.85 & 0.05 & 0.030 & 0.001 & 0.9533 \\
\hline 3 & 1926.95 & 0.05 & 0.9 & 0 & -- & -- & -- \\
\hline
\end{tabular}


Table C. 12 Flow Unit calculation for well 15-1128 into two zones.

\begin{tabular}{|c|c|c|c|c|c|c|c|}
\hline $\begin{array}{c}\text { Sample } \\
\text { No. per } \\
\text { Group }\end{array}$ & $\begin{array}{c}\text { Core } \\
\text { Depth, } \\
\text { Ft }\end{array}$ & $K, \mathrm{mD}$ & $\begin{array}{c}\text { Cum.Sum of } K \text {, } \\
\mathrm{mD}\end{array}$ & $\begin{array}{l}\text { Grand Sum M inus } \\
\text { Cum. Sum, mD }\end{array}$ & $B, m^{2}$ & $\mathrm{~W}, \mathrm{mD}^{2}$ & $\begin{array}{l}\text { Zonation } \\
\text { Index, R }\end{array}$ \\
\hline 1 & 2027.85 & 3.1 & 3.1 & 6.94 & 4.430 & 0.444 & 0.8998 \\
\hline 2 & 2029.25 & 0.8 & 3.9 & 6.14 & 1.790 & 0.821 & 0.5414 \\
\hline 3 & 2030.55 & 2.2 & 6.1 & 3.94 & 3.790 & 0.535 & 0.8588 \\
\hline 4 & 2031.65 & 1.5 & 7.6 & 2.44 & 4.431 & 0.444 & 0.9050 \\
\hline$* *$ & $* *$ & $* *$ & $* *$ & $* *$ & $* *$ & $* *$ & $* *$ \\
\hline 5 & 2032.85 & 0.38 & 7.98 & 2.06 & 2.597 & 0.706 & 0.7282 \\
\hline 6 & 2034.2 & 0.89 & 8.87 & 1.17 & 2.369 & 0.738 & 0.6883 \\
\hline 7 & 2035.6 & 0.33 & 9.2 & 0.84 & 1.244 & 0.899 & 0.2772 \\
\hline 8 & 2036.9 & 0.42 & 9.62 & 0.42 & 0.544 & 0.999 & 0 \\
\hline 9 & 2038.05 & 0.42 & 10.04 & 0 & -- & -- & -- \\
\hline
\end{tabular}

Table C . 13 Flow Unit calculation for well 15-1128 into three zones.

\begin{tabular}{|c|c|c|c|c|c|c|c|}
\hline $\begin{array}{c}\text { Sample } \\
\text { No. per } \\
\text { G roup }\end{array}$ & $\begin{array}{c}\text { Core } \\
\text { Depth, } \\
\text { Ft }\end{array}$ & $K, \mathrm{mD}$ & $\begin{array}{c}\text { Cum.Sum of } K \text {, } \\
\text { mD }\end{array}$ & $\begin{array}{l}\text { Grand Sum M inus } \\
\text { C um. Sum, mD }\end{array}$ & $B, m^{2}$ & $\mathrm{~W}, \mathrm{mD}^{2}$ & $\begin{array}{l}\text { Zonation } \\
\text { Index, R }\end{array}$ \\
\hline \multicolumn{8}{|l|}{ Group 1} \\
\hline 1 & 2027.85 & 3.1 & 3.1 & 4.5 & 3.175 & 0.198 & 0.9377 \\
\hline$* *$ & $* *$ & $* *$ & $* *$ & $* *$ & $* *$ & $* *$ & $* *$ \\
\hline 2 & 2029.25 & 0.8 & 3.9 & 3.7 & 2.220 & 0.516 & 0.7675 \\
\hline 3 & 2030.55 & 2.2 & 6.1 & 1.5 & 2.322 & 0.482 & 0.7923 \\
\hline 4 & 2031.65 & 1.5 & 7.6 & 0 & -- & -- & -- \\
\hline \multicolumn{8}{|l|}{ Group 2} \\
\hline 1 & 2032.85 & 0.38 & 0.38 & 2.06 & 2.223 & 0.515 & 0.7681 \\
\hline 2 & 2034.2 & 0.89 & 1.27 & 1.17 & 2.251 & 0.506 & 0.7753 \\
\hline 3 & 2035.6 & 0.33 & 1.6 & 0.84 & 2.223 & 0.515 & 0.7682 \\
\hline 4 & 2036.9 & 0.42 & 2.02 & 0.42 & 2.218 & 0.517 & 0.7669 \\
\hline 5 & 2038.05 & 0.42 & 2.44 & 0 & -- & -- & -- \\
\hline
\end{tabular}


Table C. 14 Flow Unit calculation for well 15-1130 into two zones.

\begin{tabular}{|c|c|c|c|c|c|c|c|}
\hline $\begin{array}{l}\text { Sample } \\
\text { No. per } \\
\text { Group }\end{array}$ & $\begin{array}{c}\text { Core } \\
\text { Depth, } \\
\text { Ft }\end{array}$ & $\mathrm{K}, \mathrm{mD}$ & $\begin{array}{c}\text { Cum.Sum of } K \text {, } \\
\text { mD }\end{array}$ & $\begin{array}{l}\text { Grand Sum Minus } \\
\text { Cum. Sum, mD }\end{array}$ & $B, m^{2}$ & $\mathrm{~W}, \mathrm{mD}^{2}$ & $\begin{array}{l}\text { Zonation } \\
\text { Index, R }\end{array}$ \\
\hline 1 & 1886 & 4.8 & 4.8 & 73.92 & 0.22 & 7.07 & $\overline{0}$ \\
\hline 2 & 1887.25 & 11 & 15.8 & 62.92 & 16.23 & 5.83 & 0.6405 \\
\hline 3 & 1888.3 & 2.5 & 18.3 & 60.42 & 2.72 & 6.87 & 0 \\
\hline 4 & 1889.35 & 2.4 & 20.7 & 58.02 & 0.03 & 7.08 & 0 \\
\hline 5 & 1890.6 & 3.7 & 24.4 & 54.32 & 1.02 & 7.00 & 0 \\
\hline 6 & 1892.05 & 6 & 30.4 & 48.32 & 0.33 & 7.06 & 0 \\
\hline 7 & 1893.35 & 6 & 36.4 & 42.32 & 0.03 & 7.08 & 0 \\
\hline 8 & 1894.5 & 7.4 & 43.8 & 34.92 & 0.88 & 7.01 & 0 \\
\hline 9 & 1895.75 & 5.7 & 49.5 & 29.22 & 1.43 & 6.97 & 0 \\
\hline 10 & 1897.1 & 8.2 & 57.7 & 21.02 & 8.17 & 6.45 & 0.2105 \\
\hline 11 & 1898.4 & 8.2 & 65.9 & 12.82 & 22.77 & 5.33 & 0.7658 \\
\hline$* *$ & $* *$ & $* *$ & $* *$ & $* *$ & $* *$ & $* *$ & $* *$ \\
\hline 12 & 1899.5 & 3.3 & 69.2 & 9.52 & 16.14 & 5.84 & 0.6381 \\
\hline 13 & 1900.85 & 3.8 & 73 & 5.72 & 13.16 & 6.07 & 0.5387 \\
\hline 14 & 1902.1 & 3.8 & 76.8 & 1.92 & 11.87 & 6.17 & 0.4801 \\
\hline 15 & 1903.35 & 1.4 & 78.2 & 0 & -- & -- & -- \\
\hline
\end{tabular}

Table C. 15 Flow Unit calculation for well 15-1130 into three zones.

\begin{tabular}{|c|c|c|c|c|c|c|c|}
\hline $\begin{array}{c}\text { Sample } \\
\text { No. per } \\
\text { Group }\end{array}$ & $\begin{array}{c}\text { Core } \\
\text { Depth, } \\
\text { Ft }\end{array}$ & $K, \mathrm{mD}$ & $\begin{array}{c}\text { Cum.Sum of } K, \\
\text { mD }\end{array}$ & $\begin{array}{l}\text { Grand Sum M inus } \\
\text { Cum. Sum, mD }\end{array}$ & $B, m D^{2}$ & $\mathrm{~W}, \mathrm{mD}^{2}$ & $\begin{array}{l}\text { Zonation } \\
\text { Index, R }\end{array}$ \\
\hline \multicolumn{8}{|l|}{ Group 1} \\
\hline 1 & 1886 & 4.8 & 4.8 & 61.1 & 10.530 & 5.918 & 0.4380 \\
\hline 2 & 1887.25 & 11 & 15.8 & 50.1 & 14.205 & 5.306 & 0.6265 \\
\hline 3 & 1888.3 & 2.5 & 18.3 & 47.6 & 9.775 & 6.044 & 0.3817 \\
\hline 4 & 1889.35 & 2.4 & 20.7 & 45.2 & 11.843 & 5.699 & 0.5187 \\
\hline 5 & 1890.6 & 3.7 & 24.4 & 41.5 & 15.407 & 5.105 & 0.6686 \\
\hline 6 & 1892.05 & 6 & 30.4 & 35.5 & 15.388 & 5.108 & 0.6680 \\
\hline 7 & 1893.35 & 6 & 36.4 & 29.5 & 15.771 & 5.045 & 0.6801 \\
\hline 8 & 1894.5 & 7.4 & 43.8 & 22.1 & 13.654 & 5.397 & 0.6047 \\
\hline 9 & 1895.75 & 5.7 & 49.5 & 16.4 & 15.715 & 5.054 & 0.6784 \\
\hline 10 & 1897.1 & 8.2 & 57.7 & 8.2 & 12.434 & 5.601 & 0.5496 \\
\hline 11 & 1898.4 & 8.2 & 65.9 & 0 & -- & -- & -- \\
\hline \multicolumn{8}{|l|}{ Group 2} \\
\hline 1 & 1899.5 & 3.3 & 3.3 & 9 & 9.784 & 6.042 & 0.3824 \\
\hline 2 & 1900.85 & 3.8 & 7.1 & 5.2 & 10.202 & 5.973 & 0.4145 \\
\hline 3 & 1902.1 & 3.8 & 10.9 & 1.4 & 11.621 & 5.736 & 0.5064 \\
\hline 4 & 1903.35 & 1.4 & 12.3 & 0 & -- & -- & -- \\
\hline
\end{tabular}


Table C. 16 Flow Unit calculation for well 15-1132 into two zones.

\begin{tabular}{|c|c|c|c|c|c|c|c|}
\hline $\begin{array}{l}\text { Sample } \\
\text { No. per } \\
\text { G roup }\end{array}$ & $\begin{array}{c}\text { Core } \\
\text { Depth, } \\
\text { Ft }\end{array}$ & $K, \mathrm{mD}$ & $\begin{array}{c}\text { Cum.Sum of } K \text {, } \\
\text { mD }\end{array}$ & $\begin{array}{l}\text { G rand Sum M inus } \\
\text { C um. Sum, mD }\end{array}$ & $B, m^{2}$ & $\mathrm{~W}, \mathrm{mD}^{2}$ & $\begin{array}{l}\text { Zonation } \\
\text { Index, R }\end{array}$ \\
\hline 1 & 1994.2 & 10 & 10 & 44.55 & 40.119 & 7.494 & 0.8132 \\
\hline 2 & 1995.6 & 3.8 & 13.8 & 40.75 & 21.050 & 9.083 & 0.5685 \\
\hline 3 & 1997.05 & 5.4 & 19.2 & 35.35 & 23.932 & 8.843 & 0.6305 \\
\hline 4 & 1998.4 & 5.4 & 24.6 & 29.95 & 28.440 & 8.467 & 0.7023 \\
\hline 5 & 1999.8 & 7.5 & 32.1 & 22.45 & 49.532 & 6.709 & 0.8645 \\
\hline 6 & 2001.3 & 8.2 & 40.3 & 14.25 & 83.514 & 3.877 & 0.9536 \\
\hline 7 & 2002.6 & 5.4 & 45.7 & 8.85 & 96.994 & 2.754 & 0.9716 \\
\hline$* *$ & $* *$ & $* *$ & $* *$ & $* *$ & $* *$ & $* *$ & $* *$ \\
\hline 8 & 2004 & 2.8 & 48.5 & 6.05 & 87.581 & 3.538 & 0.9596 \\
\hline 9 & 2005.4 & 2.2 & 50.7 & 3.85 & 76.024 & 4.502 & 0.9408 \\
\hline 10 & 2006.55 & 1.5 & 52.2 & 2.35 & 61.314 & 5.727 & 0.9066 \\
\hline 11 & 2007.7 & 1.1 & 53.3 & 1.25 & 46.233 & 6.984 & 0.8489 \\
\hline 12 & 2009.05 & 1 & 54.3 & 0.25 & 33.189 & 8.071 & 0.7568 \\
\hline 13 & 2010.4 & 0.2 & 54.5 & 0.05 & 15.933 & 9.509 & 0.4032 \\
\hline 14 & 2011.55 & 0.05 & 54.55 & 0 & -- & -- & -- \\
\hline
\end{tabular}

Table C. 17 Flow Unit calculation for well 15-1132 into three zones.

\begin{tabular}{|c|c|c|c|c|c|c|c|}
\hline $\begin{array}{c}\text { Sample } \\
\text { No. per } \\
\text { G roup }\end{array}$ & $\begin{array}{c}\text { Core } \\
\text { Depth, } \\
\text { Ft }\end{array}$ & $\mathrm{K}, \mathrm{mD}$ & $\begin{array}{c}\text { Cum.Sum of } K, \\
\text { mD }\end{array}$ & $\begin{array}{l}\text { G rand Sum M inus } \\
\text { C um. Sum, mD }\end{array}$ & $B, m^{2}$ & $\mathrm{~W}, \mathrm{mD}^{2}$ & $\begin{array}{l}\text { Zonation } \\
\text { Index, R }\end{array}$ \\
\hline \multicolumn{8}{|l|}{ Group1 } \\
\hline 1 & 1994.2 & 10 & 10 & 35.7 & 55.527 & 1.726 & 0.9689 \\
\hline 2 & 1995.6 & 3.8 & 13.8 & 31.9 & 48.690 & 2.969 & 0.9390 \\
\hline 3 & 1997.05 & 5.4 & 19.2 & 26.5 & 48.541 & 2.996 & 0.9383 \\
\hline 4 & 1998.4 & 5.4 & 24.6 & 21.1 & 49.166 & 2.883 & 0.9414 \\
\hline 5 & 1999.8 & 7.5 & 32.1 & 13.6 & 48.600 & 2.986 & 0.9386 \\
\hline 6 & 2001.3 & 8.2 & 40.3 & 5.4 & 49.240 & 2.869 & 0.9417 \\
\hline 7 & 2002.6 & 5.4 & 45.7 & 0 & -- & -- & -- \\
\hline \multicolumn{8}{|l|}{ Group 2} \\
\hline 1 & 2004 & 2.8 & 2.8 & 6.05 & 49.873 & 2.754 & 0.9448 \\
\hline 2 & 2005.4 & 2.2 & 5 & 3.85 & 50.635 & 2.616 & 0.9483 \\
\hline 3 & 2006.55 & 1.5 & 6.5 & 2.35 & 50.635 & 2.616 & 0.9483 \\
\hline 4 & 2007.7 & 1.1 & 7.6 & 1.25 & 50.383 & 2.661 & 0.9472 \\
\hline 5 & 2009.05 & 1 & 8.6 & 0.25 & 50.314 & 2.674 & 0.9469 \\
\hline 6 & 2010.4 & 0.2 & 8.8 & 0.05 & 49.357 & 2.848 & 0.9423 \\
\hline 7 & 2011.55 & 0.05 & 8.85 & 0 & -- & -- & -- \\
\hline
\end{tabular}


Table C. 18 Flow Unit calculation for well 15-1184 into two zones.

\begin{tabular}{|c|c|c|c|c|c|c|c|}
\hline $\begin{array}{l}\text { Sample } \\
\text { No. per } \\
\text { Group }\end{array}$ & $\begin{array}{c}\text { Core } \\
\text { Depth, } \\
\text { Ft }\end{array}$ & $\mathrm{K}, \mathrm{mD}$ & $\begin{array}{c}\text { Cum.Sum of } K \text {, } \\
\mathrm{mD}\end{array}$ & $\begin{array}{l}\text { Grand Sum M inus } \\
\text { C um. Sum, mD }\end{array}$ & $B, m^{2}$ & $\mathrm{~W}, \mathrm{mD}^{2}$ & $\begin{array}{l}\text { Zonation } \\
\text { Index, R }\end{array}$ \\
\hline 1 & 1873 & 2.1 & 2.1 & 88.1 & 2.369 & 4.055 & 0 \\
\hline 2 & 1874 & 1.7 & 3.8 & 86.4 & 6.342 & 3.882 & 0.3878 \\
\hline 3 & 1875 & 3.9 & 7.7 & 82.5 & 3.697 & 3.997 & 0 \\
\hline 4 & 1876 & 2.3 & 10 & 80.2 & 5.846 & 3.904 & 0.3322 \\
\hline 5 & 1877 & 4.8 & 14.8 & 75.4 & 2.624 & 4.044 & 0 \\
\hline 6 & 1878 & 5.6 & 20.4 & 69.8 & 0.342 & 4.143 & 0 \\
\hline 7 & 1879 & 3.8 & 24.2 & 66 & 0.221 & 4.149 & 0 \\
\hline 8 & 1880 & 8 & 32.2 & 58 & 2.046 & 4.069 & 0 \\
\hline 9 & 1881 & 7.2 & 39.4 & 50.8 & 8.333 & 3.796 & 0.5445 \\
\hline 10 & 1882 & 5.9 & 45.3 & 44.9 & 14.168 & 3.542 & 0.7500 \\
\hline 11 & 1883 & 4 & 49.3 & 40.9 & 14.998 & 3.506 & 0.7662 \\
\hline 12 & 1884 & 6.3 & 55.6 & 34.6 & 24.261 & 3.103 & 0.8721 \\
\hline 13 & 1885 & 5.2 & 60.8 & 29.4 & 30.945 & 2.813 & 0.9091 \\
\hline 14 & 1886 & 3.2 & 64 & 26.2 & 29.533 & 2.874 & 0.9027 \\
\hline 15 & 1887 & 3.4 & 67.4 & 22.8 & 29.393 & 2.880 & 0.9020 \\
\hline 16 & 1888 & 4.8 & 72.2 & 18 & 36.361 & 2.577 & 0.9291 \\
\hline$* *$ & $* *$ & $* *$ & $* *$ & $* *$ & $* *$ & $* *$ & $* *$ \\
\hline 17 & 1889 & 2.8 & 75 & 15.2 & 34.321 & 2.666 & 0.9223 \\
\hline 18 & 1890 & 3.3 & 78.3 & 11.9 & 35.393 & 2.619 & 0.9260 \\
\hline 19 & 1891 & 3 & 81.3 & 8.9 & 35.638 & 2.609 & 0.9268 \\
\hline 20 & 1892 & 2.8 & 84.1 & 6.1 & 35.641 & 2.609 & 0.9268 \\
\hline 21 & 1893 & 2.1 & 86.2 & 4 & 32.389 & 2.750 & 0.9151 \\
\hline 22 & 1894 & 2.2 & 88.4 & 1.8 & 30.846 & 2.817 & 0.9087 \\
\hline 23 & 1895 & 0.6 & 89 & 1.2 & 19.670 & 3.303 & 0.8321 \\
\hline 24 & 1896 & 1 & 90 & 0.2 & 12.098 & 3.632 & 0.6998 \\
\hline 25 & 1897 & 0.2 & 90.2 & 0 & -- & -- & -- \\
\hline
\end{tabular}


Table C. 19 Flow Unit calculation for well 15-1184 into three zones.

\begin{tabular}{|c|c|c|c|c|c|c|c|}
\hline $\begin{array}{c}\text { Sample } \\
\text { No. per } \\
\text { Group }\end{array}$ & $\begin{array}{c}\text { Core } \\
\text { Depth, } \\
\text { Ft }\end{array}$ & $\mathrm{K}, \mathrm{mD}$ & $\begin{array}{c}\text { C um.Sum of } K \text {, } \\
\text { mD }\end{array}$ & $\begin{array}{l}\text { Grand Sum M inus } \\
\text { C um. Sum, mD }\end{array}$ & $B, \mathrm{mD}^{2}$ & $\mathrm{~W}, \mathrm{mD}^{2}$ & $\begin{array}{l}\text { Zonation } \\
\text { Index, R }\end{array}$ \\
\hline \multicolumn{8}{|l|}{ Group 1} \\
\hline 1 & 1873 & 2.1 & 2.1 & 70.1 & 21.285 & 2.412 & 0.8867 \\
\hline 2 & 1874 & 1.7 & 3.8 & 68.4 & 25.981 & 1.985 & 0.9236 \\
\hline 3 & 1875 & 3.9 & 7.7 & 64.5 & 25.170 & 2.059 & 0.9182 \\
\hline 4 & 1876 & 2.3 & 10 & 62.2 & 28.981 & 1.713 & 0.9409 \\
\hline$* *$ & $* *$ & $* *$ & $* *$ & $* *$ & $* *$ & $* *$ & $* *$ \\
\hline 5 & 1877 & 4.8 & 14.8 & 57.4 & 26.945 & 1.898 & 0.9296 \\
\hline 6 & 1878 & 5.6 & 20.4 & 51.8 & 24.121 & 2.154 & 0.9107 \\
\hline 7 & 1879 & 3.8 & 24.2 & 48 & 25.111 & 2.064 & 0.9178 \\
\hline 8 & 1880 & 8 & 32.2 & 40 & 20.082 & 2.522 & 0.8744 \\
\hline 9 & 1881 & 7.2 & 39.4 & 32.8 & 18.367 & 2.677 & 0.8542 \\
\hline 10 & 1882 & 5.9 & 45.3 & 26.9 & 18.185 & 2.694 & 0.8518 \\
\hline 11 & 1883 & 4 & 49.3 & 22.9 & 18.197 & 2.693 & 0.8520 \\
\hline 12 & 1884 & 6.3 & 55.6 & 16.6 & 18.531 & 2.663 & 0.8563 \\
\hline 13 & 1885 & 5.2 & 60.8 & 11.4 & 19.118 & 2.609 & 0.8635 \\
\hline 14 & 1886 & 3.2 & 64 & 8.2 & 18.375 & 2.677 & 0.8543 \\
\hline 15 & 1887 & 3.4 & 67.4 & 4.8 & 18.225 & 2.690 & 0.8524 \\
\hline 16 & 1888 & 4.8 & 72.2 & 0 & -- & -- & -- \\
\hline \multicolumn{8}{|l|}{ Group 2} \\
\hline 1 & 1889 & 2.8 & 2.8 & 15.2 & 18.540 & 2.662 & 0.8564 \\
\hline 2 & 1890 & 3.3 & 6.1 & 11.9 & 19.598 & 2.566 & 0.8691 \\
\hline 3 & 1891 & 3 & 9.1 & 8.9 & 20.583 & 2.476 & 0.8797 \\
\hline 4 & 1892 & 2.8 & 11.9 & 6.1 & 21.603 & 2.383 & 0.8897 \\
\hline 5 & 1893 & 2.1 & 14 & 4 & 21.780 & 2.367 & 0.8913 \\
\hline 6 & 1894 & 2.2 & 16.2 & 1.8 & 22.590 & 2.294 & 0.8985 \\
\hline 7 & 1895 & 0.6 & 16.8 & 1.2 & 20.700 & 2.465 & 0.8809 \\
\hline 8 & 1896 & 1 & 17.8 & 0.2 & 20.003 & 2.529 & 0.8736 \\
\hline 9 & 1897 & 0.2 & 18 & 0 & -- & -- & -- \\
\hline
\end{tabular}


Table C . 20 F low Unit calculation for well 15-1184 into four zones.

\begin{tabular}{|c|c|c|c|c|c|c|c|}
\hline $\begin{array}{c}\text { Sample } \\
\text { No. per } \\
\text { Group }\end{array}$ & $\begin{array}{c}\text { Core } \\
\text { Depth, } \\
\text { Ft }\end{array}$ & $\mathrm{K}, \mathrm{mD}$ & $\begin{array}{c}\text { C um.Sum of } K \text {, } \\
\text { mD }\end{array}$ & $\begin{array}{l}\text { G rand Sum M inus } \\
\text { Cum. Sum, mD }\end{array}$ & $B, m^{2}$ & $\mathrm{~W}, \mathrm{mD}^{2}$ & $\begin{array}{l}\text { Zonation } \\
\text { Index, R }\end{array}$ \\
\hline \multicolumn{8}{|l|}{ Group 1} \\
\hline 1 & 1873 & 2.1 & 2.1 & 7.9 & 11.088 & 3.339 & 0.6988 \\
\hline 2 & 1874 & 1.7 & 3.8 & 6.2 & 11.701 & 3.283 & 0.7194 \\
\hline 3 & 1875 & 3.9 & 7.7 & 2.3 & 11.008 & 3.347 & 0.6960 \\
\hline 4 & 1876 & 2.3 & 10 & 0 & -- & -- & -- \\
\hline \multicolumn{8}{|l|}{ Group 2} \\
\hline 1 & 1877 & 4.8 & 4.8 & 57.4 & 11.061 & 3.342 & 0.6979 \\
\hline 2 & 1878 & 5.6 & 10.4 & 51.8 & 10.981 & 3.349 & 0.6950 \\
\hline 3 & 1879 & 3.8 & 14.2 & 48 & 11.386 & 3.312 & 0.7091 \\
\hline 4 & 1880 & 8 & 22.2 & 40 & 11.384 & 3.312 & 0.7090 \\
\hline 5 & 1881 & 7.2 & 29.4 & 32.8 & 13.061 & 3.160 & 0.7581 \\
\hline 6 & 1882 & 5.9 & 35.3 & 26.9 & 13.921 & 3.082 & 0.7786 \\
\hline 7 & 1883 & 4 & 39.3 & 22.9 & 12.541 & 3.207 & 0.7443 \\
\hline 8 & 1884 & 6.3 & 45.6 & 16.6 & 14.184 & 3.058 & 0.7844 \\
\hline 9 & 1885 & 5.2 & 50.8 & 11.4 & 14.808 & 3.001 & 0.7973 \\
\hline 10 & 1886 & 3.2 & 54 & 8.2 & 12.389 & 3.221 & 0.7400 \\
\hline 11 & 1887 & 3.4 & 57.4 & 4.8 & 11.061 & 3.342 & 0.6979 \\
\hline 12 & 1888 & 4.8 & 62.2 & 0 & -- & -- & -- \\
\hline \multicolumn{8}{|l|}{ Group 3} \\
\hline 1 & 1889 & 2.8 & 2.8 & 15.2 & 18.540 & 2.662 & 0.8564 \\
\hline 2 & 1890 & 3.3 & 6.1 & 11.9 & 19.598 & 2.566 & 0.8691 \\
\hline 3 & 1891 & 3 & 9.1 & 8.9 & 20.583 & 2.476 & 0.8797 \\
\hline 4 & 1892 & 2.8 & 11.9 & 6.1 & 21.603 & 2.383 & 0.8897 \\
\hline 5 & 1893 & 2.1 & 14 & 4 & 21.780 & 2.367 & 0.8913 \\
\hline 6 & 1894 & 2.2 & 16.2 & 1.8 & 22.590 & 2.294 & 0.8985 \\
\hline 7 & 1895 & 0.6 & 16.8 & 1.2 & 20.700 & 2.465 & 0.8809 \\
\hline 8 & 1896 & 1 & 17.8 & 0.2 & 20.003 & 2.529 & 0.8736 \\
\hline 9 & 1897 & 0.2 & 18 & 0 & -- & -- & -- \\
\hline
\end{tabular}


Table C. 21 Flow Unit calculation for well 15-1309 into two zones.

\begin{tabular}{|c|c|c|c|c|c|c|c|}
\hline $\begin{array}{l}\text { Sample } \\
\text { No. per } \\
\text { G roup }\end{array}$ & $\begin{array}{c}\text { Core } \\
\text { Depth, } \\
\text { Ft }\end{array}$ & $\mathrm{K}, \mathrm{mD}$ & $\underset{\mathrm{mD}}{\text { Cum.Sum of } K \text {, }}$ & $\begin{array}{c}\text { Grand Sum M inus } \\
\text { Cum. Sum, mD }\end{array}$ & $B, m D^{2}$ & $\mathbf{W}, \mathrm{mD}^{2}$ & $\begin{array}{l}\text { Zonation } \\
\text { Index, R }\end{array}$ \\
\hline 1 & 1961.5 & 9.6 & 9.6 & 79.8 & 17.174 & 7.357 & 0.5716 \\
\hline 2 & 1962.5 & 7.5 & 17.1 & 72.3 & 20.060 & 7.151 & 0.6435 \\
\hline 3 & 1963.5 & 3.8 & 20.9 & 68.5 & 7.023 & 8.082 & 0.0000 \\
\hline 4 & 1964.5 & 9.1 & 30 & 59.4 & 19.508 & 7.190 & 0.6314 \\
\hline 5 & 1965.5 & 9.1 & 39.1 & 50.3 & 36.248 & 5.995 & 0.8346 \\
\hline 6 & 1966.5 & 5.9 & 45 & 44.4 & 35.114 & 6.076 & 0.8270 \\
\hline 7 & 1967.5 & 5.5 & 50.5 & 38.9 & 32.933 & 6.231 & 0.8108 \\
\hline 8 & 1968.5 & 5.9 & 56.4 & 33 & 34.223 & 6.139 & 0.8206 \\
\hline 9 & 1969.5 & 4.2 & 60.6 & 28.8 & 27.009 & 6.655 & 0.7536 \\
\hline 10 & 1970.5 & 7 & 67.6 & 21.8 & 36.660 & 5.965 & 0.8373 \\
\hline 11 & 1971.5 & 7.1 & 74.7 & 14.7 & 50.976 & 4.943 & 0.9030 \\
\hline 12 & 1972.5 & 5.7 & 80.4 & 9 & 59.408 & 4.340 & 0.9269 \\
\hline 13 & 1973.5 & 5.5 & 85.9 & 3.5 & 72.162 & 3.429 & 0.9525 \\
\hline$* *$ & $* *$ & $* *$ & $* *$ & $* *$ & $* *$ & $* *$ & $* *$ \\
\hline 14 & 1974.5 & 3.4 & 89.3 & 0.1 & 70.089 & 3.577 & 0.9490 \\
\hline 15 & 1980.5 & 0.05 & 89.35 & 0.05 & 32.708 & 6.247 & 0.8090 \\
\hline 16 & 1981.5 & 0.05 & 89.4 & 0 & -- & -- & -- \\
\hline
\end{tabular}

Table C. 22 Flow Unit calculation for well 15-1309 into three zones.

\begin{tabular}{|c|c|c|c|c|c|c|c|}
\hline $\begin{array}{l}\text { Sample } \\
\text { No. per } \\
\text { G roup }\end{array}$ & $\begin{array}{c}\text { Core } \\
\text { Depth, } \\
\text { Ft }\end{array}$ & $\mathrm{K}, \mathrm{mD}$ & $\begin{array}{c}\text { C um.Sum of } K, \\
\mathrm{mD}\end{array}$ & $\begin{array}{l}\text { Grand Sum M inus } \\
\text { Cum. Sum, mD }\end{array}$ & $B, m^{2}$ & $\mathrm{~W}, \mathrm{mD}^{2}$ & $\begin{array}{l}\text { Zonation } \\
\text { Index, R }\end{array}$ \\
\hline \multicolumn{8}{|l|}{ Group 1 } \\
\hline 1 & 1961.5 & 9.6 & 9.6 & 76.3 & 40.931 & 2.947 & 0.9280 \\
\hline 2 & 1962.5 & 7.5 & 17.1 & 68.8 & 40.539 & 3.007 & 0.9258 \\
\hline 3 & 1963.5 & 3.8 & 20.9 & 65 & 36.332 & 3.654 & 0.8994 \\
\hline 4 & 1964.5 & 9.1 & 30 & 55.9 & 38.381 & 3.339 & 0.9130 \\
\hline 5 & 1965.5 & 9.1 & 39.1 & 46.8 & 42.051 & 2.775 & 0.9340 \\
\hline 6 & 1966.5 & 5.9 & 45 & 40.9 & 40.517 & 3.011 & 0.9257 \\
\hline 7 & 1967.5 & 5.5 & 50.5 & 35.4 & 38.871 & 3.264 & 0.9160 \\
\hline 8 & 1968.5 & 5.9 & 56.4 & 29.5 & 38.115 & 3.380 & 0.9113 \\
\hline 9 & 1969.5 & 4.2 & 60.6 & 25.3 & 36.312 & 3.658 & 0.8993 \\
\hline 10 & 1970.5 & 7 & 67.6 & 18.3 & 36.583 & 3.616 & 0.9012 \\
\hline 11 & 1971.5 & 7.1 & 74.7 & 11.2 & 37.281 & 3.509 & 0.9059 \\
\hline 12 & 1972.5 & 5.7 & 80.4 & 5.5 & 36.745 & 3.591 & 0.9023 \\
\hline 13 & 1973.5 & 5.5 & 85.9 & 0 & -- & -- & -- \\
\hline \multicolumn{8}{|l|}{ Group 2} \\
\hline 1 & 1974.5 & 3.4 & 3.4 & 0.1 & 39.822 & 3.118 & 0.9217 \\
\hline 2 & 1980.5 & 0.05 & 3.45 & 0.05 & 37.016 & 3.549 & 0.9041 \\
\hline 3 & 1981.5 & 0.05 & 3.5 & 0 & -- & -- & -- \\
\hline
\end{tabular}




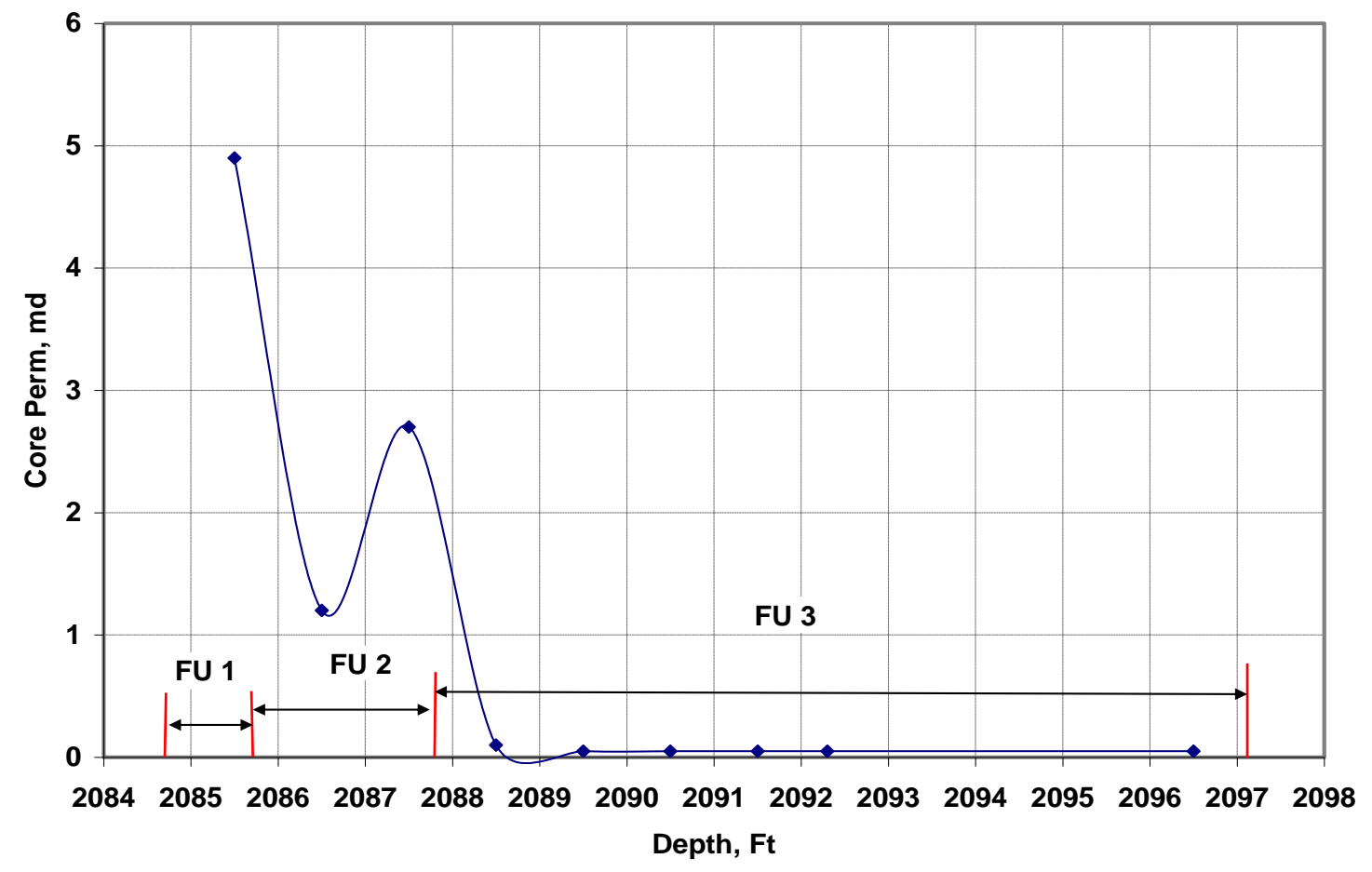

Figure C. 1 Flow Unit identification in well 15-733.

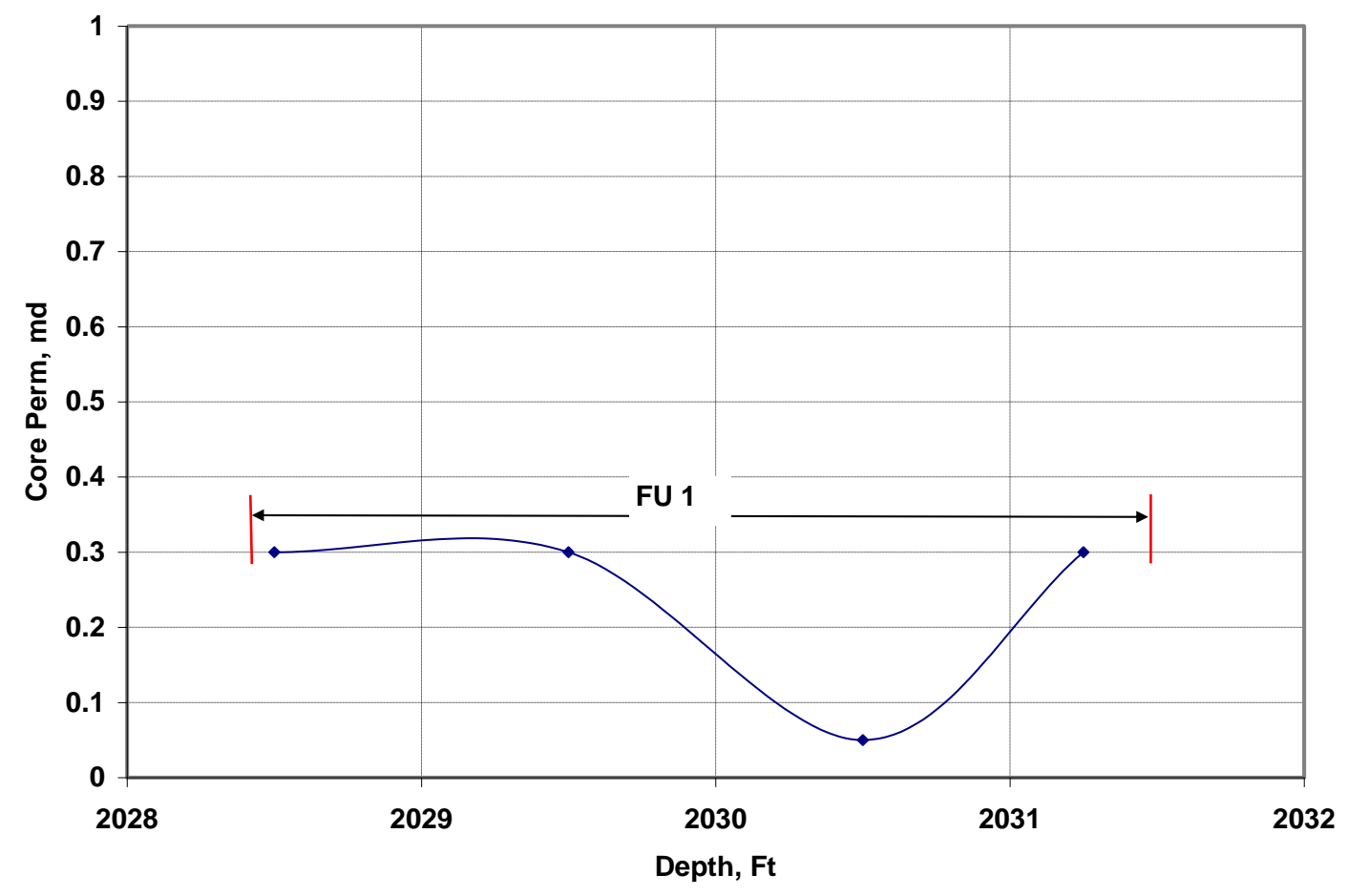

Figure C. 2 Flow Unit identification in well 15-1059. 


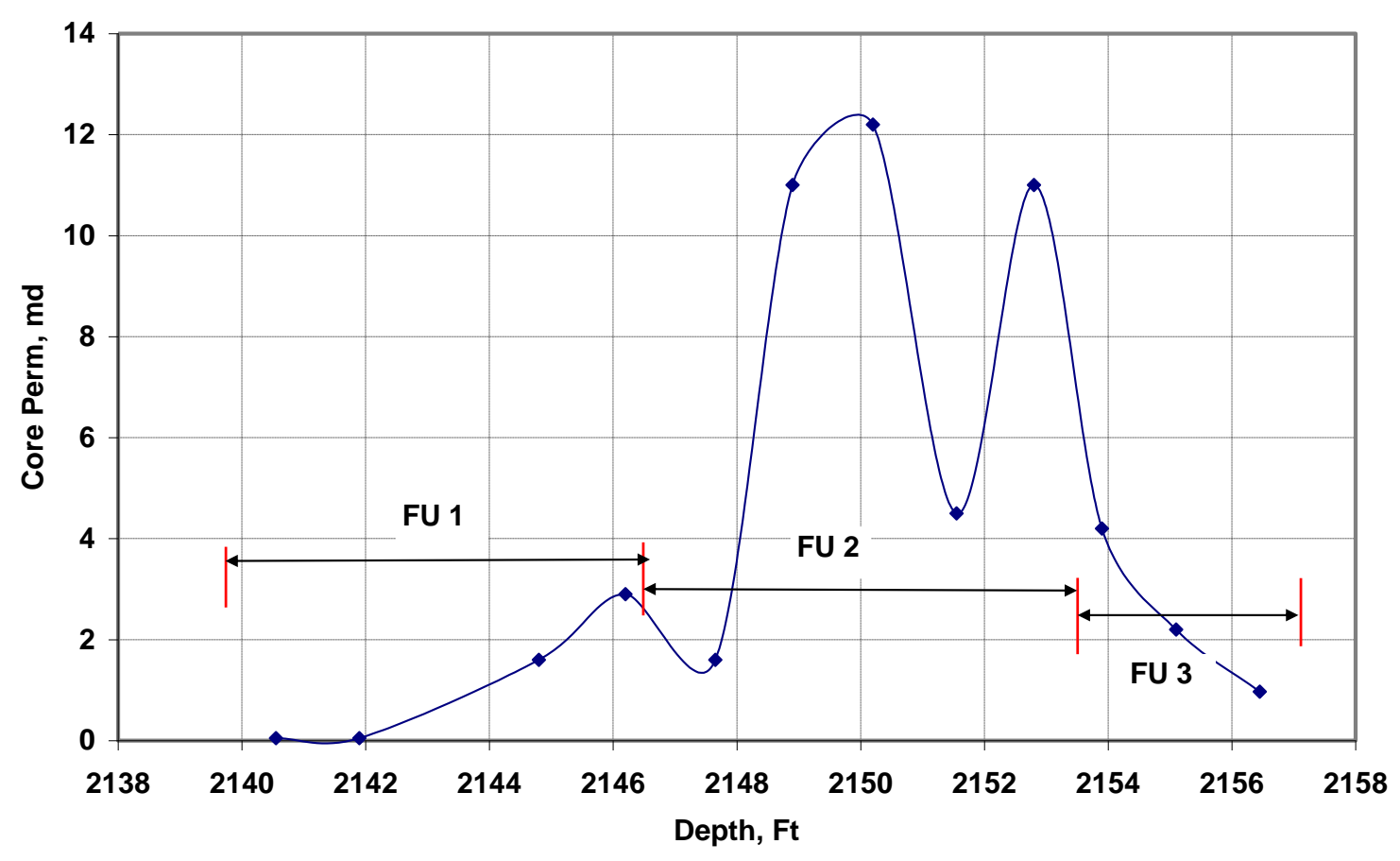

Figure C. 3 Flow Unit identification in well 15-1107.

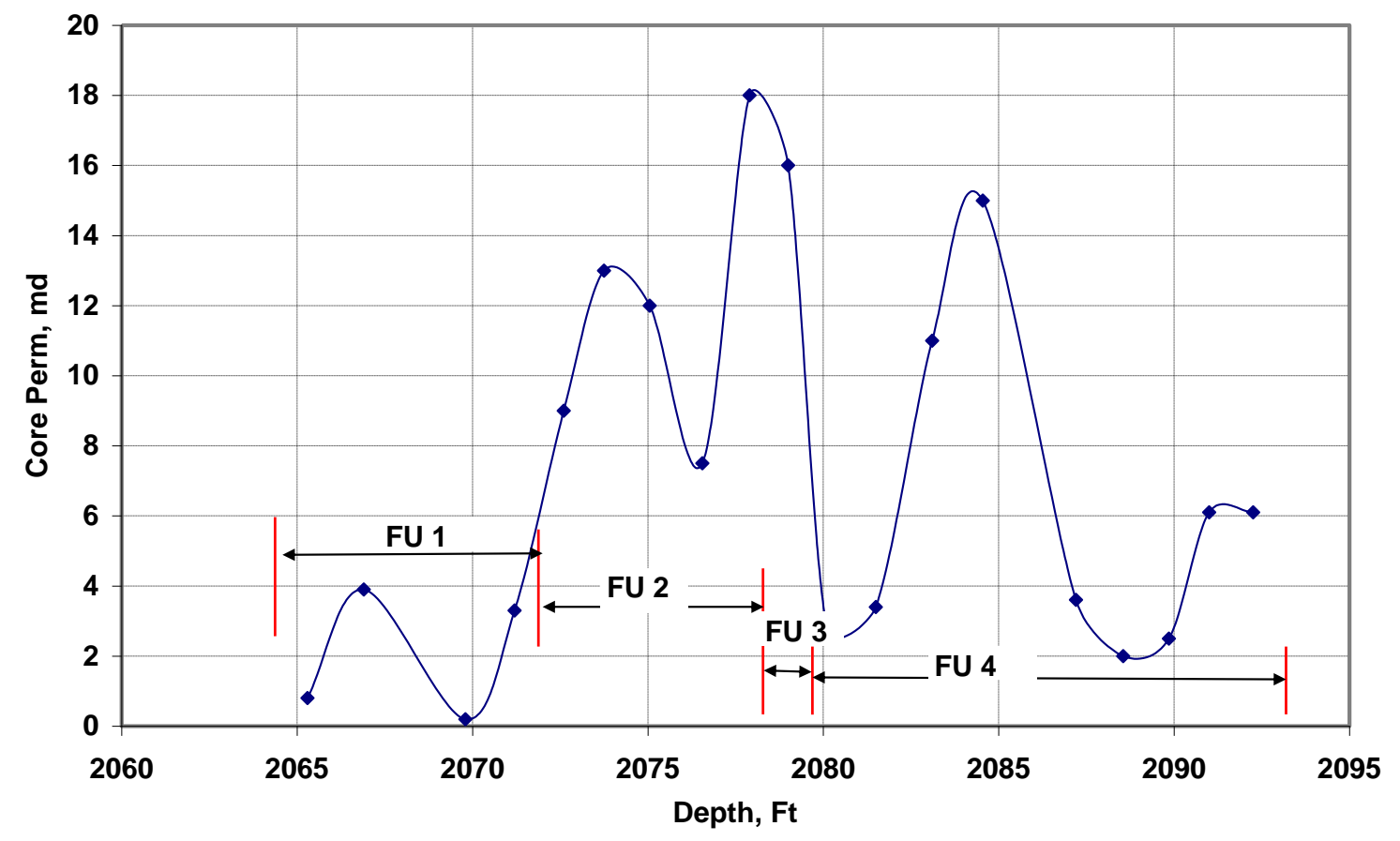

Figure C. 4 Flow Unit identification in well 15-1108. 


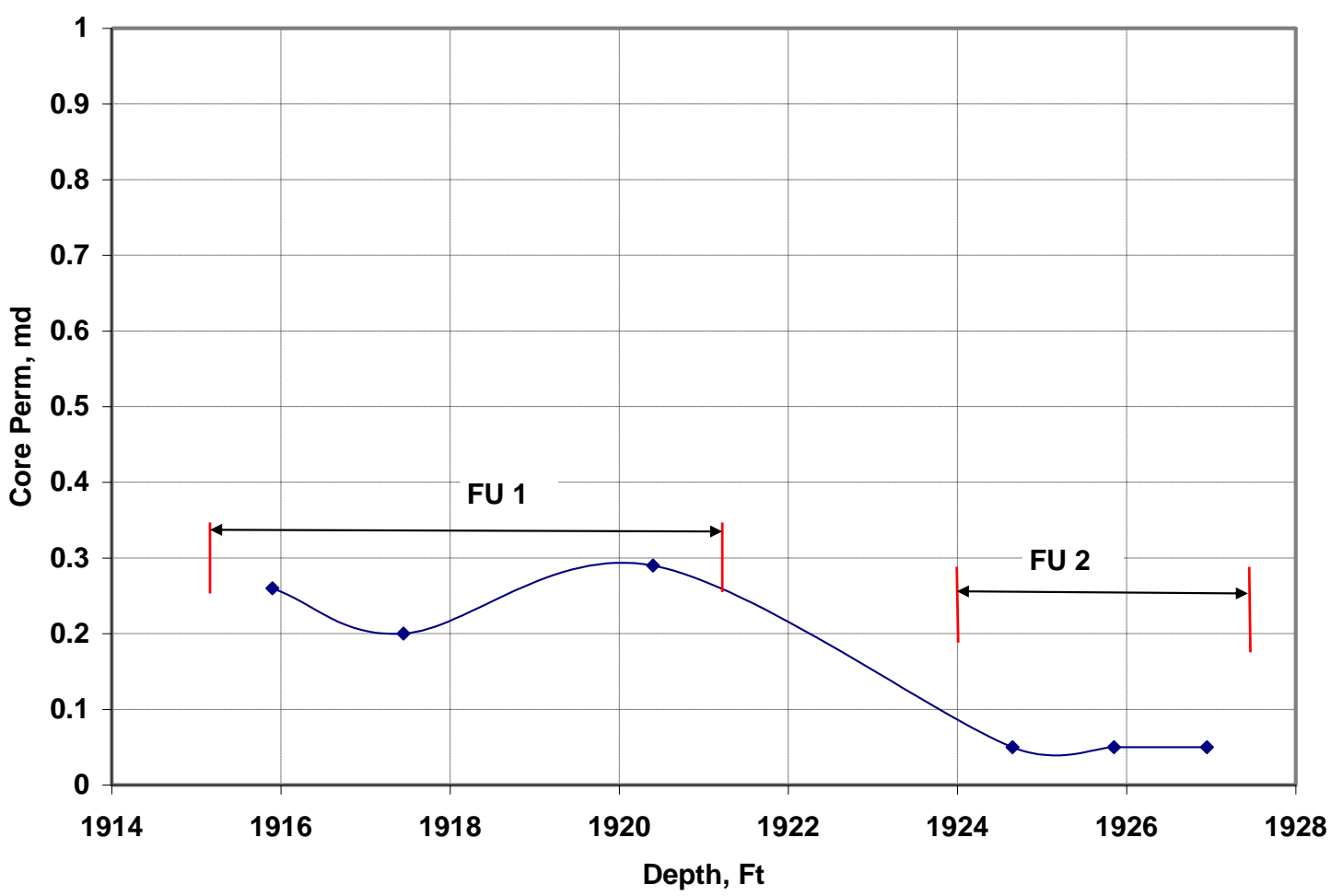

Figure C . 5 Flow Unit identification in well 15-1109.

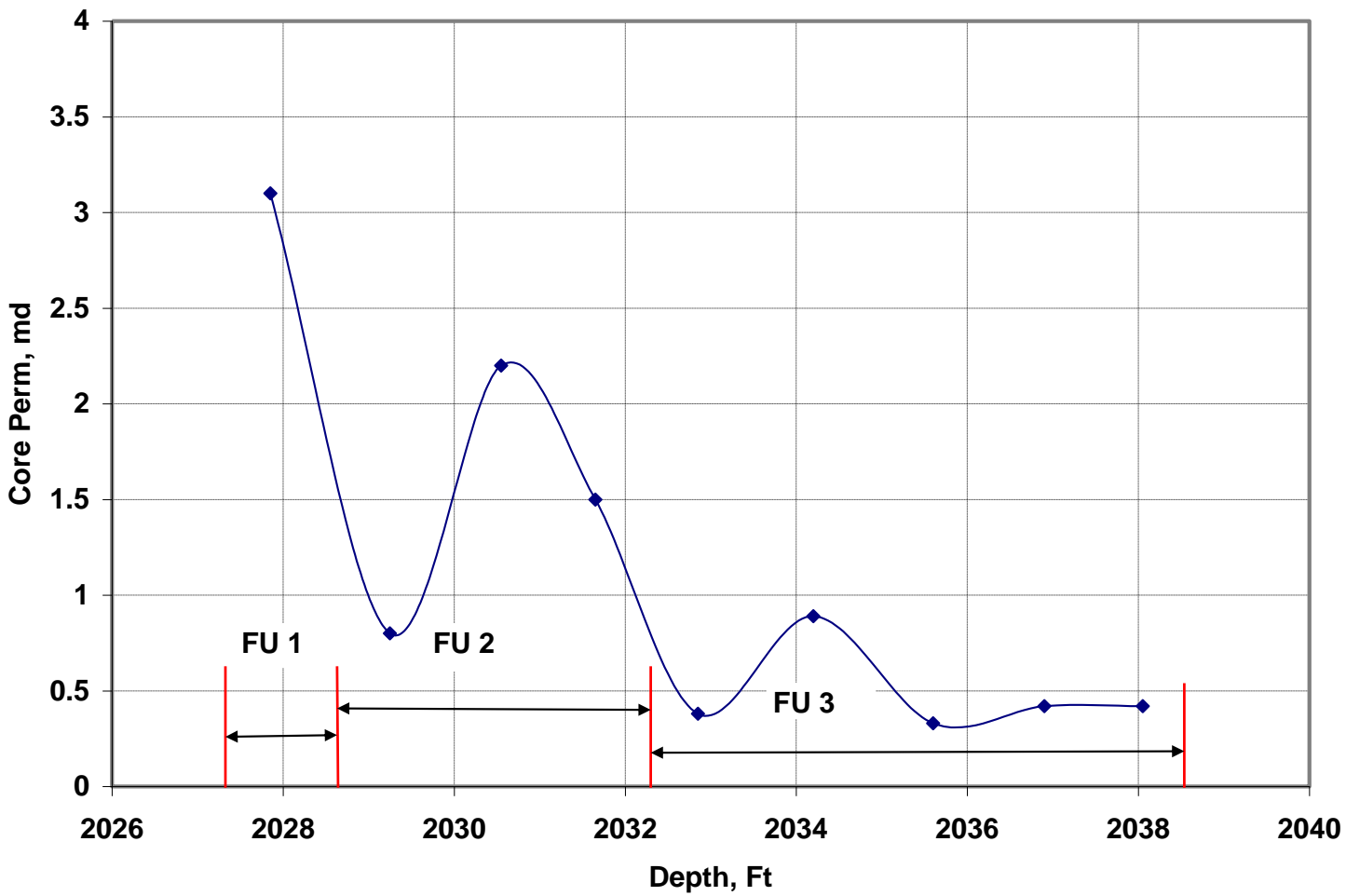

Figure C. 6 Flow Unit identification in well 15-1128. 


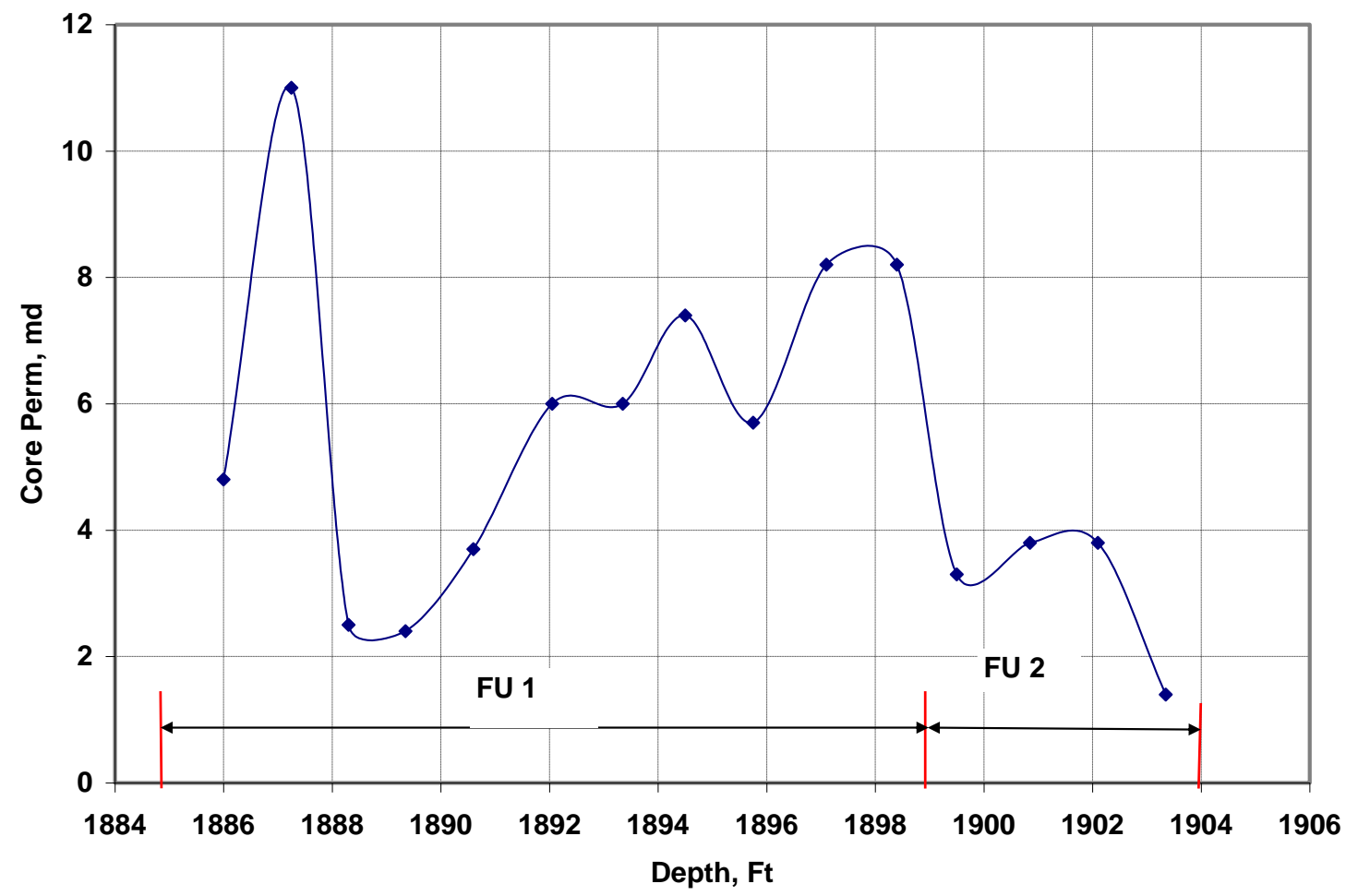

Figure C. 7 Flow Unit identification in well 15-1130.

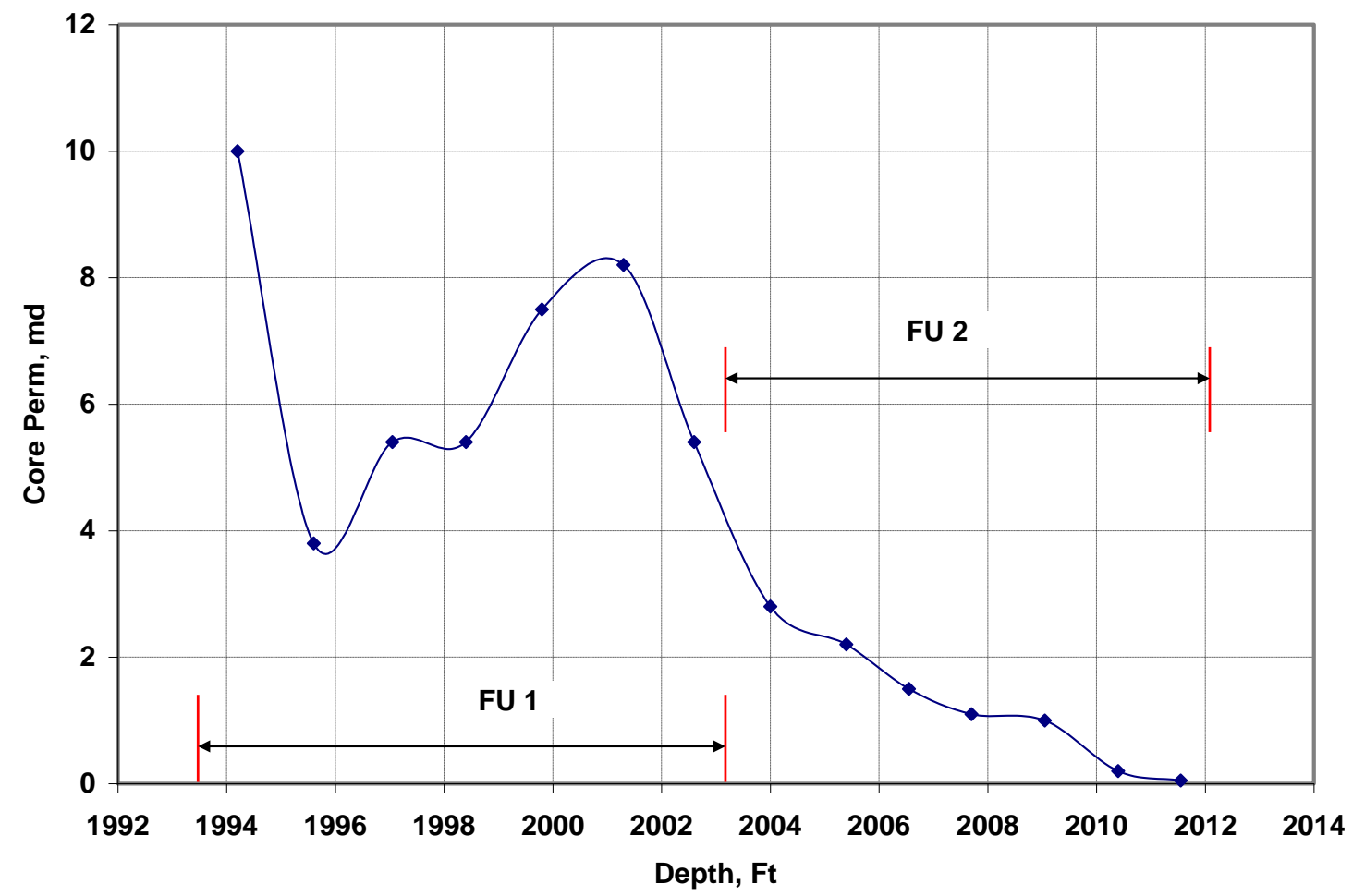

Figure C. 8 Flow Unit identification in well 15-1132. 


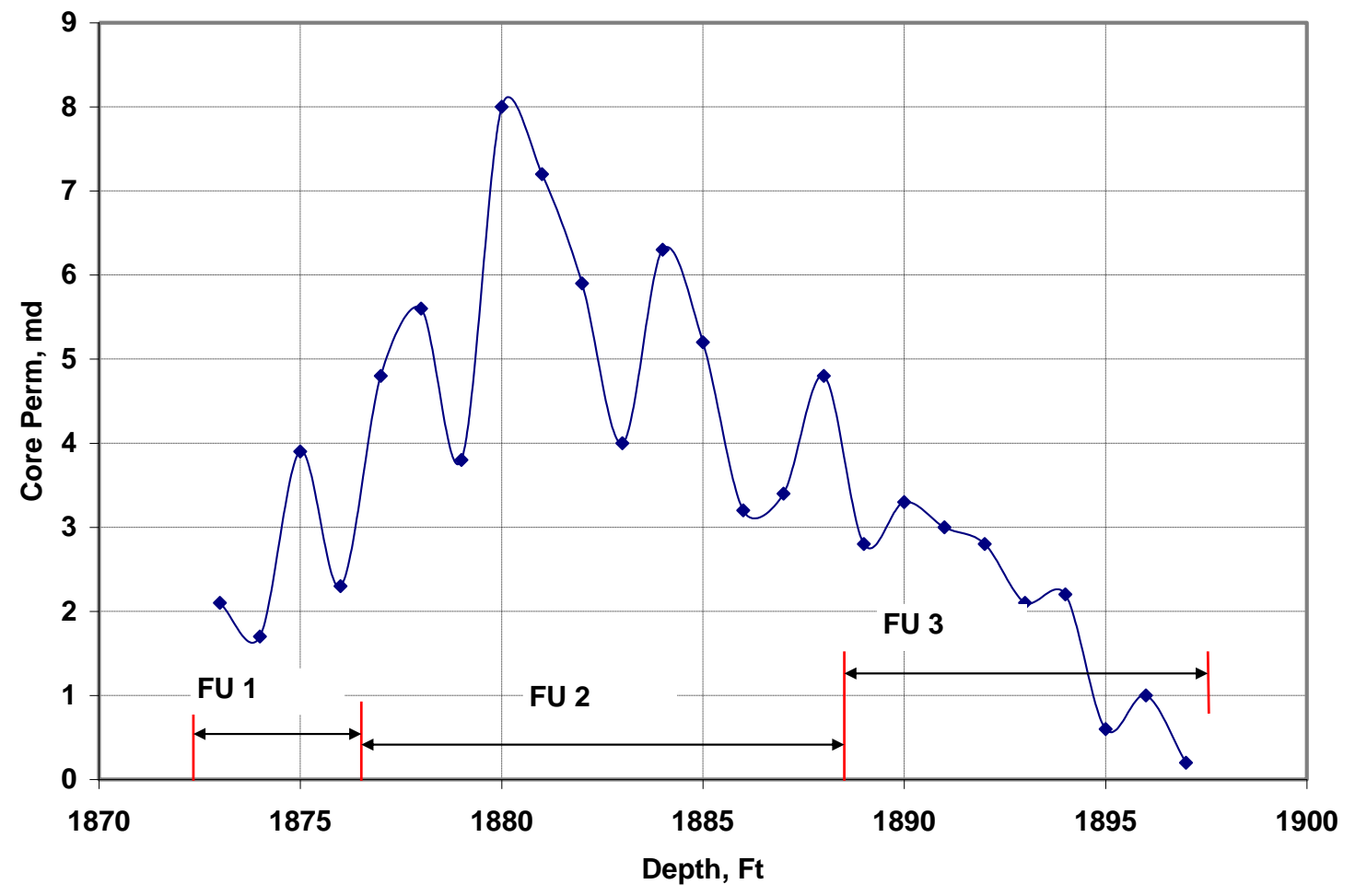

Figure C. 9 Flow Unit identification in well 15-1184.

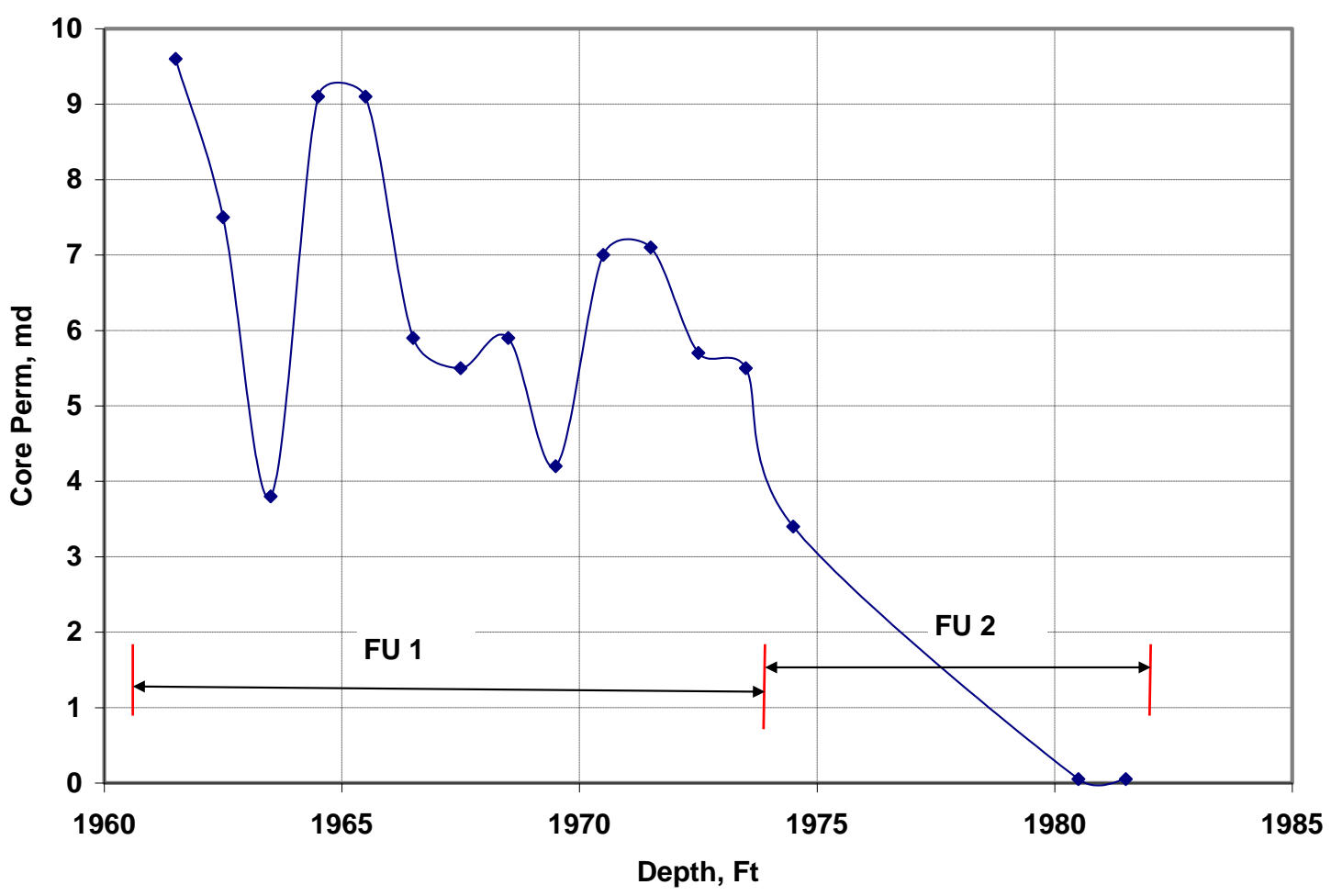

Figure C. 10 F low Unit identification in well 15-1309. 


\section{APPENDIX D. \\ Deter mination of F low Unit by Statistical Z onation Technique using predicted permeability for cored wells.}


Table D. 1 Flow Unit calculation with Predicted K for well 15-733 into two zones.

\begin{tabular}{|c|c|c|c|c|c|c|c|}
\hline $\begin{array}{l}\text { Sample } \\
\text { No. per } \\
\text { Group }\end{array}$ & $\begin{array}{c}\text { Core } \\
\text { Depth, } \\
\text { Ft }\end{array}$ & $\begin{array}{l}\text { Predicted K, } \\
\text { mD }\end{array}$ & $\begin{array}{c}\text { Cum.Sum of } K \text {, } \\
\text { mD }\end{array}$ & $\begin{array}{l}\text { Grand Sum Minus } \\
\text { Cum. Sum, mD }\end{array}$ & $B, m^{2}$ & $\mathrm{~W}, \mathrm{mD}^{2}$ & $\begin{array}{l}\text { Zonation } \\
\text { Index, R }\end{array}$ \\
\hline 1 & 2085.5 & 3.48 & 3.48 & 5.18 & 7.118 & 0.495 & 0.9304 \\
\hline 2 & 2086.5 & 2.18 & 5.65 & 3.00 & 8.953 & 0.233 & 0.9740 \\
\hline$* *$ & $* *$ & $* *$ & $* *$ & $* *$ & $* *$ & $* *$ & $* *$ \\
\hline 3 & 2087.5 & 1.15 & 6.80 & 1.85 & 7.672 & 0.416 & 0.9458 \\
\hline 4 & 2088.5 & 0.65 & 7.45 & 1.21 & 5.836 & 0.678 & 0.8838 \\
\hline 5 & 2089.5 & 0.42 & 7.86 & 0.79 & 4.201 & 0.912 & 0.7829 \\
\hline 6 & 2090.5 & 0.19 & 8.05 & 0.60 & 2.606 & 1.140 & 0.5625 \\
\hline 7 & 2091.5 & 0.13 & 8.18 & 0.47 & 1.357 & 1.318 & 0.0289 \\
\hline 8 & 2092.3 & 0.29 & 8.47 & 0.18 & 0.680 & 1.415 & 0.0000 \\
\hline 9 & 2096.5 & 0.18 & 8.65 & 0 & -- & -- & -- \\
\hline
\end{tabular}

Table D. 2 Flow U nit calculation with Predicted K for well 15-733 into three zones.

\begin{tabular}{|c|c|c|c|c|c|c|c|}
\hline $\begin{array}{l}\text { Sample } \\
\text { No. per } \\
\text { Group }\end{array}$ & $\begin{array}{c}\text { Core } \\
\text { Depth, } \\
\text { Ft }\end{array}$ & $\begin{array}{l}\text { Predicted K, } \\
\text { mD }\end{array}$ & $\begin{array}{c}\text { Cum.Sum of } K, \\
\text { mD }\end{array}$ & $\begin{array}{l}\text { Grand Sum Minus } \\
\text { Cum. Sum, mD }\end{array}$ & $B, m^{2}$ & $\mathrm{~W}, \mathrm{mD}^{2}$ & $\begin{array}{l}\text { Zonation } \\
\text { Index, R }\end{array}$ \\
\hline \multicolumn{8}{|l|}{ Group 1 } \\
\hline 1 & 2085.5 & 3.48 & 3.48 & 2.18 & 4.898 & 0.131 & 0.9732 \\
\hline 2 & 2086.5 & 2.18 & 5.65 & 0 & -- & -- & -- \\
\hline \multicolumn{8}{|l|}{ Group 2} \\
\hline 1 & 2087.5 & 1.15 & 1.15 & 1.85 & 4.777 & 0.172 & 0.9641 \\
\hline 2 & 2088.5 & 0.65 & 1.79 & 1.21 & 4.783 & 0.170 & 0.9645 \\
\hline 3 & 2089.5 & 0.42 & 2.21 & 0.79 & 4.725 & 0.189 & 0.9599 \\
\hline 4 & 2090.5 & 0.19 & 2.40 & 0.60 & 4.613 & 0.227 & 0.9509 \\
\hline 5 & 2091.5 & 0.13 & 2.53 & 0.47 & 4.529 & 0.255 & 0.9438 \\
\hline 6 & 2092.3 & 0.29 & 2.81 & 0.18 & 4.511 & 0.260 & 0.9423 \\
\hline 7 & 2096.5 & 0.18 & 3.00 & 0 & -- & -- & -- \\
\hline
\end{tabular}


Table D. 3 Flow Unit calculation with Predicted K for well 15-1059 into two zones.

\begin{tabular}{|c|c|c|c|c|c|c|c|}
\hline $\begin{array}{l}\text { Sample } \\
\text { No. per } \\
\text { Group }\end{array}$ & $\begin{array}{c}\text { Core } \\
\text { Depth, } \\
\text { Ft }\end{array}$ & $\begin{array}{l}\text { Predicted K, } \\
\text { mD }\end{array}$ & $\begin{array}{c}\text { Cum.Sum of } K, \\
\mathrm{mD}\end{array}$ & $\begin{array}{l}\text { Grand Sum Minus } \\
\text { Cum. Sum, mD }\end{array}$ & $B, m D^{2}$ & $\mathrm{~W}, \mathrm{mD}^{2}$ & $\begin{array}{l}\text { Zonation } \\
\text { Index, R }\end{array}$ \\
\hline 1 & 2028.5 & 0.16 & $\overline{0.16}$ & 0.26 & 0.004 & 0.003 & 0.1611 \\
\hline 2 & 2029.5 & 0.11 & 0.27 & 0.14 & 0.004 & 0.003 & 0.3133 \\
\hline 3 & 2030.5 & 0.02 & 0.29 & 0.12 & 0.001 & 0.005 & 0 \\
\hline 4 & 2031.25 & 0.12 & 0.41 & 0.00 & -- & -- & -- \\
\hline
\end{tabular}

Table D. 4 Flow Unit calculation with Predicted K for well 15-1107 into two zones.

\begin{tabular}{|c|c|c|c|c|c|c|c|}
\hline $\begin{array}{l}\text { Sample } \\
\text { No. per } \\
\text { Group }\end{array}$ & $\begin{array}{c}\text { Core } \\
\text { Depth, } \\
\text { Ft }\end{array}$ & $\begin{array}{l}\text { Predicted K, } \\
\text { mD }\end{array}$ & $\underset{\mathrm{mD}}{\text { Cum.Sum of } K,}$ & $\begin{array}{l}\text { Grand Sum Minus } \\
\text { Cum. Sum, mD }\end{array}$ & $B, m^{2}$ & $\mathrm{~W}, \mathrm{mD}^{2}$ & $\begin{array}{l}\text { Zonation } \\
\text { Index, R }\end{array}$ \\
\hline 1 & 2140.55 & 0.24 & 0.24 & 53.03 & 19.273 & 6.613 & 0.6569 \\
\hline 2 & 2141.9 & 0.31 & 0.54 & 52.72 & 41.704 & 4.370 & 0.8952 \\
\hline$* *$ & $* *$ & $* *$ & $* *$ & $* *$ & $* *$ & $* *$ & $* *$ \\
\hline 3 & 2144.8 & 5.16 & 5.70 & 47.57 & 25.789 & 5.961 & 0.7688 \\
\hline 4 & 2146.2 & 6.49 & 12.19 & 41.08 & 11.617 & 7.379 & 0.3648 \\
\hline 5 & 2147.65 & 7.18 & 19.37 & 33.90 & 2.742 & 8.266 & 0 \\
\hline 6 & 2148.9 & 7.71 & 27.08 & 26.19 & 0.066 & 8.534 & 0 \\
\hline 7 & 2150.2 & 7.18 & 34.25 & 19.01 & 3.470 & 8.193 & 0 \\
\hline 8 & 2151.55 & 6.22 & 40.47 & 12.80 & 9.223 & 7.618 & 0.1740 \\
\hline 9 & 2152.8 & 5.08 & 45.55 & 7.71 & 13.965 & 7.144 & 0.4884 \\
\hline 10 & 2153.9 & 4.60 & 50.15 & 3.11 & 19.944 & 6.546 & 0.6718 \\
\hline 11 & 2155.1 & 1.59 & 51.74 & 1.52 & 9.278 & 7.613 & 0.1795 \\
\hline 12 & 2156.45 & 1.52 & 53.27 & 0 & -- & - & - \\
\hline
\end{tabular}


Table D. 5 F low Unit calculation with Predicted K for well 15-1107 into three zones.

\begin{tabular}{|c|c|c|c|c|c|c|c|}
\hline $\begin{array}{l}\text { Sample } \\
\text { No. per } \\
\text { Group }\end{array}$ & $\begin{array}{c}\text { Core } \\
\text { Depth, } \\
\text { Ft }\end{array}$ & $\begin{array}{l}\text { Predicted K, } \\
\text { mD }\end{array}$ & $\underset{\mathrm{mD}}{\text { Cum.Sum of } K \text {, }}$ & $\begin{array}{l}\text { Grand Sum M inus } \\
\text { Cum. Sum, mD }\end{array}$ & $B, m^{2}$ & $\mathbf{W}, \mathrm{mD}^{2}$ & $\begin{array}{l}\text { Zonation } \\
\text { Index, R }\end{array}$ \\
\hline \multicolumn{8}{|l|}{ Group 1 } \\
\hline 1 & 2140.55 & 0.24 & 0.24 & 0.31 & 20.853 & 4.855 & 0.7672 \\
\hline 2 & 2141.9 & 0.31 & 0.54 & 0 & -- & -- & -- \\
\hline \multicolumn{8}{|l|}{ Group 2} \\
\hline 1 & 2144.8 & 5.16 & 5.16 & 47.57 & 20.859 & 4.854 & 0.7673 \\
\hline 2 & 2146.2 & 6.49 & 11.65 & 41.08 & 21.233 & 4.771 & 0.7753 \\
\hline 3 & 2147.65 & 7.18 & 18.83 & 33.90 & 23.006 & 4.377 & 0.8097 \\
\hline 4 & 2148.9 & 7.71 & 26.54 & 26.19 & 27.031 & 3.483 & 0.8712 \\
\hline 5 & 2150.2 & 7.18 & 33.71 & 19.01 & 31.656 & 2.455 & 0.9225 \\
\hline 6 & 2151.55 & 6.22 & 39.93 & 12.80 & 35.184 & 1.671 & 0.9525 \\
\hline 7 & 2152.8 & 5.08 & 45.01 & 7.71 & 36.499 & 1.378 & 0.9622 \\
\hline 8 & 2153.9 & 4.60 & 49.61 & 3.11 & 38.117 & 1.019 & 0.9733 \\
\hline$* *$ & $* *$ & $* *$ & $* *$ & $* *$ & $* *$ & $* *$ & $* *$ \\
\hline 9 & 2155.1 & 1.59 & 51.20 & 1.52 & 28.664 & 3.120 & 0.8912 \\
\hline 10 & 2156.45 & 1.52 & 52.72 & 0 & -- & -- & -- \\
\hline
\end{tabular}

Table D. 6 Flow Unit calculation with Predicted K for well 15-1107 into four zones.

\begin{tabular}{|c|c|c|c|c|c|c|c|}
\hline $\begin{array}{l}\text { Sample } \\
\text { No. per } \\
\text { Group }\end{array}$ & $\begin{array}{c}\text { Core } \\
\text { Depth, } \\
\text { Ft }\end{array}$ & $\begin{array}{l}\text { Predicted K, } \\
\text { mD }\end{array}$ & $\begin{array}{c}\text { Cum.Sum of } K \text {, } \\
\mathrm{mD}\end{array}$ & $\begin{array}{l}\text { Grand Sum M inus } \\
\text { Cum. Sum, mD }\end{array}$ & $B, m^{2}$ & $\mathrm{~W}, \mathrm{mD}^{2}$ & $\begin{array}{l}\text { Zonation } \\
\text { Index, R }\end{array}$ \\
\hline \multicolumn{8}{|l|}{ Group 1 } \\
\hline 1 & 2140.55 & 0.24 & 0.24 & 0.31 & 20.853 & 4.855 & 0.7672 \\
\hline 2 & 2141.9 & 0.31 & 0.54 & 0 & -- & -- & -- \\
\hline \multicolumn{8}{|l|}{ Group 2} \\
\hline 1 & 2144.8 & 5.16 & 5.16 & 44.45 & 38.665 & 0.897 & 0.9768 \\
\hline 2 & 2146.2 & 6.49 & 11.65 & 37.96 & 38.233 & 0.993 & 0.9740 \\
\hline 3 & 2147.65 & 7.18 & 18.83 & 30.79 & 38.057 & 1.032 & 0.9729 \\
\hline 4 & 2148.9 & 7.71 & 26.54 & 23.08 & 38.791 & 0.869 & 0.9776 \\
\hline 5 & 2150.2 & 7.18 & 33.71 & 15.90 & 39.994 & 0.602 & 0.9850 \\
\hline 6 & 2151.55 & 6.22 & 39.93 & 9.68 & 40.509 & 0.487 & 0.9880 \\
\hline$* *$ & ** & $* *$ & $* *$ & $* *$ & $* *$ & $* *$ & $* *$ \\
\hline 7 & 2152.8 & 5.08 & 45.01 & 4.60 & 39.512 & 0.709 & 0.9821 \\
\hline 8 & 2153.9 & 4.60 & 49.61 & 0 & -- & -- & -- \\
\hline \multicolumn{8}{|l|}{ Group 3} \\
\hline 1 & 2155.1 & 1.59 & 1.59 & 1.52 & 38.045 & 1.035 & 0.9728 \\
\hline 2 & 2156.45 & 1.52 & 3.11 & 0 & -- & -- & -- \\
\hline
\end{tabular}


Table D. 7 Flow Unit calculation with Predicted K for well 15-1108 into two zones.

\begin{tabular}{|c|c|c|c|c|c|c|c|}
\hline $\begin{array}{l}\text { Sample } \\
\text { No. per } \\
\text { Group }\end{array}$ & $\begin{array}{c}\text { Core } \\
\text { Depth, } \\
\text { Ft }\end{array}$ & $\begin{array}{l}\text { Predicted K, } \\
\text { mD }\end{array}$ & $\begin{array}{c}\text { C um.Sum of } K, \\
\text { mD }\end{array}$ & $\begin{array}{l}\text { Grand Sum Minus } \\
\text { C um. Sum, mD }\end{array}$ & $B, m D^{2}$ & $W, m D^{2}$ & $\begin{array}{l}\text { Zonation } \\
\text { Index, R }\end{array}$ \\
\hline 1 & 2065.3 & 3.03 & 3.03 & 105.23 & 7.488 & 12.892 & 0 \\
\hline 2 & 2066.9 & 3.67 & 6.70 & 101.56 & 12.298 & 12.609 & 0 \\
\hline 3 & 2069.8 & 7.03 & 13.73 & 94.53 & 4.469 & 13.070 & 0 \\
\hline 4 & 2071.2 & 7.73 & 21.46 & 86.80 & 0.558 & 13.300 & 0 \\
\hline 5 & 2072.6 & 9.65 & 31.11 & 77.15 & 1.870 & 13.223 & 0 \\
\hline 6 & 2073.75 & 9.50 & 40.61 & 67.65 & 10.056 & 12.741 & 0 \\
\hline 7 & 2075.05 & 10.78 & 51.40 & 56.87 & 29.966 & 11.570 & 0.6139 \\
\hline 8 & 2076.55 & 9.50 & 60.90 & 47.37 & 50.613 & 10.356 & 0.7954 \\
\hline 9 & 2077.9 & 6.92 & 67.81 & 40.45 & 57.693 & 9.939 & 0.8277 \\
\hline 10 & 2079 & 6.81 & 74.62 & 33.64 & 65.713 & 9.467 & 0.8559 \\
\hline 11 & 2080.1 & 8.24 & 82.86 & 25.40 & 87.934 & 8.160 & 0.9072 \\
\hline 12 & 2081.5 & 7.26 & 90.12 & 18.15 & 106.888 & 7.045 & 0.9341 \\
\hline 13 & 2083.1 & 7.73 & 97.85 & 10.42 & 137.638 & 5.236 & 0.9620 \\
\hline 14 & 2084.55 & 6.60 & 104.44 & 3.82 & 165.191 & 3.616 & 0.9781 \\
\hline$* *$ & $* *$ & $* *$ & $* *$ & $* *$ & $* *$ & $* *$ & $* *$ \\
\hline 15 & 2087.2 & 1.29 & 105.73 & 2.53 & 129.997 & 5.686 & 0.9563 \\
\hline 16 & 2088.55 & 0.61 & 106.34 & 1.92 & 91.158 & 7.971 & 0.9126 \\
\hline 17 & 2089.85 & 1.21 & 107.55 & 0.71 & 63.833 & 9.578 & 0.8500 \\
\hline 18 & 2091 & 0.57 & 108.13 & 0.13 & 32.682 & 11.410 & 0.6509 \\
\hline 19 & 2092.25 & 0.13 & 108.26 & 0 & -- & -- & -- \\
\hline
\end{tabular}


Table D. 8 F low Unit calculation with Predicted K for well 15-1108 into three zones.

\begin{tabular}{|c|c|c|c|c|c|c|c|}
\hline $\begin{array}{c}\text { Sample } \\
\text { No. per } \\
\text { G roup }\end{array}$ & $\begin{array}{c}\text { Core } \\
\text { Depth, } \\
\text { Ft }\end{array}$ & $\begin{array}{c}\text { Predicted K, } \\
\text { mD }\end{array}$ & $\begin{array}{c}\text { Cum.Sum of } K \text {, } \\
\text { mD }\end{array}$ & $\begin{array}{l}\text { Grand Sum M inus } \\
\text { C um. Sum, mD }\end{array}$ & $B, m^{2}$ & $\mathrm{~W}, \mathrm{mD}^{2}$ & $\begin{array}{l}\text { Zonation } \\
\text { Index, R }\end{array}$ \\
\hline \multicolumn{8}{|l|}{ Group 1} \\
\hline 1 & 2065.3 & 3.03 & 3.03 & 101.41 & 93.141 & 2.523 & 0.9729 \\
\hline 2 & 2066.9 & 3.67 & 6.70 & 97.74 & 102.281 & 1.381 & 0.9865 \\
\hline$* *$ & $* *$ & $* *$ & $* *$ & $* *$ & $* *$ & $* *$ & $* *$ \\
\hline 3 & 2069.8 & 7.03 & 13.73 & 90.71 & 98.454 & 1.859 & 0.9811 \\
\hline 4 & 2071.2 & 7.73 & 21.46 & 82.98 & 94.874 & 2.307 & 0.9757 \\
\hline 5 & 2072.6 & 9.65 & 31.11 & 73.33 & 88.548 & 3.098 & 0.9650 \\
\hline 6 & 2073.75 & 9.50 & 40.61 & 63.83 & 85.104 & 3.528 & 0.9585 \\
\hline 7 & 2075.05 & 10.78 & 51.40 & 53.05 & 82.693 & 3.830 & 0.9537 \\
\hline 8 & 2076.55 & 9.50 & 60.90 & 43.55 & 82.810 & 3.815 & 0.9539 \\
\hline 9 & 2077.9 & 6.92 & 67.81 & 36.63 & 82.666 & 3.833 & 0.9536 \\
\hline 10 & 2079 & 6.81 & 74.62 & 29.82 & 82.595 & 3.842 & 0.9535 \\
\hline 11 & 2080.1 & 8.24 & 82.86 & 21.58 & 82.730 & 3.825 & 0.9538 \\
\hline 12 & 2081.5 & 7.26 & 90.12 & 14.33 & 82.698 & 3.829 & 0.9537 \\
\hline 13 & 2083.1 & 7.73 & 97.85 & 6.60 & 82.996 & 3.792 & 0.9543 \\
\hline 14 & 2084.55 & 6.60 & 104.44 & 0 & -- & -- & -- \\
\hline \multicolumn{8}{|l|}{ Group 2} \\
\hline 1 & 2087.2 & 1.29 & 1.29 & 2.53 & 82.768 & 3.820 & 0.9538 \\
\hline 2 & 2088.55 & 0.61 & 1.90 & 1.92 & 82.653 & 3.834 & 0.9536 \\
\hline 3 & 2089.85 & 1.21 & 3.11 & 0.71 & 82.875 & 3.807 & 0.9541 \\
\hline 4 & 2091 & 0.57 & 3.69 & 0.13 & 82.844 & 3.811 & 0.9540 \\
\hline 5 & 2092.25 & 0.13 & 3.82 & 0 & -- & -- & -- \\
\hline
\end{tabular}


Table D. 9 Flow Unit calculation with Predicted K for well 15-1108 into four zones.

\begin{tabular}{|c|c|c|c|c|c|c|c|}
\hline $\begin{array}{l}\text { Sample } \\
\text { No. per } \\
\text { Group }\end{array}$ & $\begin{array}{c}\text { Core } \\
\text { Depth, } \\
\text { Ft }\end{array}$ & $\begin{array}{l}\text { Predicted K, } \\
\text { mD }\end{array}$ & $\begin{array}{c}\text { Cum.Sum of } K, \\
\mathrm{mD}\end{array}$ & $\begin{array}{l}\text { Grand Sum Minus } \\
\text { C um. Sum, mD }\end{array}$ & $B, m D^{2}$ & $\mathrm{~W}, \mathrm{mD}^{2}$ & $\begin{array}{l}\text { Zonation } \\
\text { Index, R }\end{array}$ \\
\hline \multicolumn{8}{|l|}{ Group 1 } \\
\hline 1 & 2065.3 & 3.03 & 3.03 & 3.67 & 100.922 & 1.551 & 0.9846 \\
\hline 2 & 2066.9 & 3.67 & 6.70 & 0 & -- & -- & -- \\
\hline \multicolumn{8}{|l|}{ Group 2} \\
\hline 1 & 2069.8 & 7.03 & 7.03 & 90.71 & 101.500 & 1.479 & 0.9854 \\
\hline 2 & 2071.2 & 7.73 & 14.76 & 82.98 & 101.524 & 1.476 & 0.9855 \\
\hline 3 & 2072.6 & 9.65 & 24.41 & 73.33 & 100.821 & 1.563 & 0.9845 \\
\hline 4 & 2073.75 & 9.50 & 33.91 & 63.83 & 101.153 & 1.522 & 0.9850 \\
\hline 5 & 2075.05 & 10.78 & 44.69 & 53.05 & 103.520 & 1.226 & 0.9882 \\
\hline 6 & 2076.55 & 9.50 & 54.19 & 43.55 & 105.541 & 0.973 & 0.9908 \\
\hline$* *$ & $* *$ & $* *$ & $* *$ & $* *$ & $* *$ & $* *$ & $* *$ \\
\hline 7 & 2077.9 & 6.92 & 61.11 & 36.63 & 103.696 & 1.204 & 0.9884 \\
\hline 8 & 2079 & 6.81 & 67.92 & 29.82 & 102.250 & 1.385 & 0.9865 \\
\hline 9 & 2080.1 & 8.24 & 76.15 & 21.58 & 102.628 & 1.338 & 0.9870 \\
\hline 10 & 2081.5 & 7.26 & 83.41 & 14.33 & 101.976 & 1.419 & 0.9861 \\
\hline 11 & 2083.1 & 7.73 & 91.14 & 6.60 & 102.127 & 1.400 & 0.9863 \\
\hline 12 & 2084.55 & 6.60 & 97.74 & 0 & -- & -- & -- \\
\hline \multicolumn{8}{|l|}{ Group 3} \\
\hline 1 & 2087.2 & 1.29 & 1.29 & 2.53 & 82.768 & 3.820 & 0.9538 \\
\hline 2 & 2088.55 & 0.61 & 1.90 & 1.92 & 82.653 & 3.834 & 0.9536 \\
\hline 3 & 2089.85 & 1.21 & 3.11 & 0.71 & 82.875 & 3.807 & 0.9541 \\
\hline 4 & 2091 & 0.57 & 3.69 & 0.13 & 82.844 & 3.811 & 0.9540 \\
\hline 5 & 2092.25 & 0.13 & 3.82 & 0 & -- & -- & -- \\
\hline
\end{tabular}


Table D. 10 F low Unit calculation with Predicted K for well 15-1109 into two zones.

\begin{tabular}{cccccccc}
$\begin{array}{c}\text { Sample } \\
\begin{array}{c}\text { No. per } \\
\text { Group }\end{array}\end{array}$ & $\begin{array}{c}\text { Copth, } \\
\text { Dept }\end{array}$ & $\begin{array}{c}\text { Predicted K, Cum.Sum of K, } \\
\text { mD }\end{array}$ & $\begin{array}{c}\text { Grand Sum M inus } \\
\text { m }\end{array}$ & $\begin{array}{c}\text { Cum. Sum, mD } \\
\text { B, mD }\end{array}$ & $\mathbf{~ W , ~ m D ~}$ & $\begin{array}{c}\text { Zonation } \\
\text { Index, R }\end{array}$ \\
\hline 1 & 1915.9 & 0.88 & 0.88 & 3.66 & 0.018 & 0.393 & 0 \\
2 & 1917.45 & 1.62 & 2.50 & 2.04 & 0.730 & 0.215 & 0.7057 \\
3 & 1920.4 & 1.07 & 3.56 & 0.97 & 1.123 & 0.117 & 0.8961 \\
$* *$ & $* *$ & $* *$ & $* *$ & $* *$ & $* *$ & $* *$ & $* *$ \\
4 & 1924.65 & 0.65 & 4.21 & 0.32 & 1.059 & 0.133 & 0.8748 \\
5 & 1925.85 & 0.24 & 4.45 & 0.08 & 0.544 & 0.261 & 0.5193 \\
6 & 1926.95 & 0.08 & 4.53 & 0 & -- & -- & --
\end{tabular}

Table D. 11 Flow Unit calculation with Predicted K for well 15-1109 into three zones.

\begin{tabular}{|c|c|c|c|c|c|c|c|}
\hline $\begin{array}{c}\text { Sample } \\
\text { No. per } \\
\text { Group }\end{array}$ & $\begin{array}{c}\text { Core } \\
\text { Depth, } \\
\text { Ft }\end{array}$ & $\begin{array}{l}\text { Predicted K, } \\
\text { mD }\end{array}$ & $\begin{array}{c}\text { Cum.Sum of } K \text {, } \\
\text { mD }\end{array}$ & $\begin{array}{l}\text { Grand Sum Minus } \\
\text { Cum. Sum, mD }\end{array}$ & $B, m^{2}$ & $\mathrm{~W}, \mathrm{mD}^{2}$ & $\begin{array}{l}\text { Zonation } \\
\text { Index, R }\end{array}$ \\
\hline \multicolumn{8}{|l|}{ Group 1 } \\
\hline 1 & 1915.9 & 0.88 & 0.88 & 2.69 & 0.634 & 0.107 & 0.8305 \\
\hline 2 & 1917.45 & 1.62 & 2.50 & 1.07 & 0.573 & 0.148 & 0.7411 \\
\hline 3 & 1920.4 & 1.07 & 3.56 & 0 & -- & -- & -- \\
\hline \multicolumn{8}{|l|}{ Group 2} \\
\hline 1 & 1924.65 & 0.65 & 0.65 & 0.32 & 0.640 & 0.103 & 0.8385 \\
\hline 2 & 1925.85 & 0.24 & 0.89 & 0.08 & 0.605 & 0.127 & 0.7907 \\
\hline 3 & 1926.95 & 0.08 & 0.97 & 0 & -- & -- & -- \\
\hline
\end{tabular}


Table D. 12 Flow Unit calculation with Predicted K for well 15-1128 into two zones.

\begin{tabular}{|c|c|c|c|c|c|c|c|}
\hline $\begin{array}{c}\text { Sample } \\
\text { No. per } \\
\text { G roup }\end{array}$ & $\begin{array}{c}\text { Core } \\
\text { Depth, } \\
\text { Ft }\end{array}$ & $\begin{array}{l}\text { Predicted K, } \\
\text { mD }\end{array}$ & $\begin{array}{c}\text { Cum.Sum of } K \text {, } \\
\mathrm{mD}\end{array}$ & $\begin{array}{l}\text { Grand Sum M inus } \\
\text { Cum. Sum, mD }\end{array}$ & $B, m D^{2}$ & $\mathrm{~W}, \mathrm{mD}^{2}$ & $\begin{array}{l}\text { Zonation } \\
\text { Index, R }\end{array}$ \\
\hline 1 & 2027.85 & 1.32 & 1.32 & 7.08 & 0.169 & 0.219 & 0 \\
\hline 2 & 2029.25 & 1.58 & 2.90 & 5.51 & 0.683 & 0.146 & 0.7864 \\
\hline 3 & 2030.55 & 1.32 & 4.22 & 4.19 & 1.006 & 0.100 & 0.9008 \\
\hline 4 & 2031.65 & 1.09 & 5.31 & 3.09 & 1.117 & 0.084 & 0.9248 \\
\hline 5 & 2032.85 & 0.96 & 6.27 & 2.14 & 1.148 & 0.080 & 0.9306 \\
\hline 6 & 2034.2 & 0.89 & 7.15 & 1.25 & 1.202 & 0.072 & 0.9402 \\
\hline$* *$ & $* *$ & $* *$ & $* *$ & $* *$ & $* *$ & $* *$ & $* *$ \\
\hline 7 & 2035.6 & 0.72 & 7.88 & 0.53 & 1.151 & 0.079 & 0.9313 \\
\hline 8 & 2036.9 & 0.37 & 8.25 & 0.16 & 0.677 & 0.147 & 0.7833 \\
\hline 9 & 2038.05 & 0.16 & 8.41 & 0 & -- & -- & -- \\
\hline
\end{tabular}

Table D. 13 Flow Unit calculation with Predicted K for well 15-1128 into three zones.

\begin{tabular}{|c|c|c|c|c|c|c|c|}
\hline $\begin{array}{l}\text { Sample } \\
\text { No. per } \\
\text { G roup }\end{array}$ & $\begin{array}{c}\text { Core } \\
\text { Depth, } \\
\text { Ft }\end{array}$ & $\begin{array}{l}\text { Predicted K, } \\
\text { mD }\end{array}$ & $\begin{array}{c}\text { Cum.Sum of } K, \\
\mathrm{mD}\end{array}$ & $\begin{array}{l}\text { Grand Sum M inus } \\
\text { Cum. Sum, mD }\end{array}$ & $B, m D^{2}$ & $\mathrm{~W}, \mathrm{mD}^{2}$ & $\begin{array}{l}\text { Zonation } \\
\text { Index, R }\end{array}$ \\
\hline \multicolumn{8}{|l|}{ Group 1 } \\
\hline 1 & 2027.85 & 1.32 & 1.32 & 5.83 & 0.611 & 0.081 & 0.8682 \\
\hline 2 & 2029.25 & 1.58 & 2.90 & 4.26 & 0.700 & 0.051 & 0.9274 \\
\hline 3 & 2030.55 & 1.32 & 4.22 & 2.93 & 0.739 & 0.038 & 0.9407 \\
\hline 4 & 2031.65 & 1.09 & 5.31 & 1.84 & 0.711 & 0.047 & 0.9337 \\
\hline 5 & 2032.85 & 0.96 & 6.27 & 0.89 & 0.657 & 0.065 & 0.9006 \\
\hline 6 & 2034.2 & 0.89 & 7.15 & 0 & -- & -- & -- \\
\hline \multicolumn{8}{|l|}{ Group 2} \\
\hline 1 & 2035.6 & 0.72 & 0.72 & 0.53 & 0.671 & 0.061 & 0.9096 \\
\hline 2 & 2036.9 & 0.37 & 1.09 & 0.16 & 0.651 & 0.067 & 0.8970 \\
\hline 3 & 2038.05 & 0.16 & 1.25 & 0 & -- & -- & -- \\
\hline
\end{tabular}


Table D. 14 Flow Unit calculation with Predicted K for well 15-1130 into two zones.

\begin{tabular}{|c|c|c|c|c|c|c|c|}
\hline $\begin{array}{l}\text { Sample } \\
\text { No. per } \\
\text { Group }\end{array}$ & $\begin{array}{c}\text { Core } \\
\text { Depth, } \\
\text { Ft }\end{array}$ & $\begin{array}{l}\text { Predicted K, } \\
\text { mD }\end{array}$ & $\underset{\mathrm{mD}}{\mathrm{Cum} \text {.Sum of } K \text {, }}$ & $\begin{array}{l}\text { Grand Sum Minus } \\
\text { Cum. Sum, mD }\end{array}$ & $B, m D^{2}$ & $\mathbf{W}, \mathrm{mD}^{2}$ & $\begin{array}{l}\text { Zonation } \\
\text { Index, R }\end{array}$ \\
\hline 1 & 1886 & 1.88 & 1.88 & 25.50 & 0.003 & 0.204 & $\overline{0}$ \\
\hline 2 & 1887.25 & 2.03 & 3.91 & 23.47 & 0.039 & 0.201 & 0 \\
\hline 3 & 1888.3 & 2.35 & 6.27 & 21.12 & 0.259 & 0.184 & 0.2897 \\
\hline 4 & 1889.35 & 2.18 & 8.44 & 18.94 & 0.443 & 0.170 & 0.6160 \\
\hline 5 & 1890.6 & 2.16 & 10.60 & 16.79 & 0.648 & 0.154 & 0.7619 \\
\hline 6 & 1892.05 & 1.97 & 12.57 & 14.81 & 0.726 & 0.148 & 0.7961 \\
\hline 7 & 1893.35 & 1.97 & 14.54 & 12.84 & 0.835 & 0.140 & 0.8325 \\
\hline 8 & 1894.5 & 2.16 & 16.70 & 10.68 & 1.176 & 0.114 & 0.9034 \\
\hline 9 & 1895.75 & 2.03 & 18.73 & 8.65 & 1.472 & 0.091 & 0.9383 \\
\hline 10 & 1897.1 & 1.97 & 20.71 & 6.68 & 1.800 & 0.066 & 0.9636 \\
\hline 11 & 1898.4 & 1.84 & 22.55 & 4.84 & 2.075 & 0.044 & 0.9786 \\
\hline 12 & 1899.5 & 1.65 & 24.20 & 3.18 & 2.197 & 0.035 & 0.9841 \\
\hline$* *$ & $* *$ & $* *$ & $* *$ & $* *$ & $* *$ & $* *$ & $* *$ \\
\hline 13 & 1900.85 & 1.25 & 25.45 & 1.93 & 1.701 & 0.073 & 0.9570 \\
\hline 14 & 1902.1 & 1.11 & 26.56 & 0.83 & 1.070 & 0.122 & 0.8863 \\
\hline 15 & 1903.35 & 0.83 & 27.38 & 0 & -- & -- & -- \\
\hline
\end{tabular}

Table D. 15 Flow Unit calculation with Predicted K for well 15-1130 into three zones.

\begin{tabular}{|c|c|c|c|c|c|c|c|}
\hline $\begin{array}{c}\text { Sample } \\
\text { No. per } \\
\text { Group }\end{array}$ & $\begin{array}{c}\text { Core } \\
\text { Depth, } \\
\text { Ft }\end{array}$ & $\begin{array}{l}\text { Predicted K, } \\
\text { mD }\end{array}$ & $\underset{\mathrm{mD}}{\text { Cum.Sum of } \mathrm{K} \text {, }}$ & $\begin{array}{l}\text { Grand Sum M inus } \\
\text { Cum. Sum, mD }\end{array}$ & $B, m^{2}$ & $\mathrm{~W}, \mathrm{mD}^{2}$ & $\begin{array}{l}\text { Zonation } \\
\text { Index, R }\end{array}$ \\
\hline \multicolumn{8}{|l|}{ Group 1 } \\
\hline 1 & 1886 & 1.88 & 1.88 & 22.32 & 1.109 & 0.036 & 0.9674 \\
\hline 2 & 1887.25 & 2.03 & 3.91 & 20.29 & 1.103 & 0.037 & 0.9663 \\
\hline 3 & 1888.3 & 2.35 & 6.27 & 17.94 & 1.109 & 0.036 & 0.9673 \\
\hline 4 & 1889.35 & 2.18 & 8.44 & 15.76 & 1.125 & 0.034 & 0.9702 \\
\hline 5 & 1890.6 & 2.16 & 10.60 & 13.61 & 1.144 & 0.030 & 0.9734 \\
\hline 6 & 1892.05 & 1.97 & 12.57 & 11.63 & 1.135 & 0.032 & 0.9720 \\
\hline 7 & 1893.35 & 1.97 & 14.54 & 9.66 & 1.130 & 0.033 & 0.9710 \\
\hline 8 & 1894.5 & 2.16 & 16.70 & 7.50 & 1.158 & 0.028 & 0.9758 \\
\hline 9 & 1895.75 & 2.03 & 18.73 & 5.47 & 1.173 & 0.025 & 0.9783 \\
\hline 10 & 1897.1 & 1.97 & 20.71 & 3.50 & 1.185 & 0.024 & 0.9801 \\
\hline 11 & 1898.4 & 1.84 & 22.55 & 1.65 & 1.170 & 0.026 & 0.9778 \\
\hline 12 & 1899.5 & 1.65 & 24.20 & 0 & -- & -- & -- \\
\hline \multicolumn{8}{|l|}{ Group 2} \\
\hline 1 & 1900.85 & 1.25 & 1.25 & 1.93 & 1.125 & 0.034 & 0.9701 \\
\hline 2 & 1902.1 & 1.11 & 2.35 & 0.83 & 1.140 & 0.031 & 0.9727 \\
\hline 3 & 1903.35 & 0.83 & 3.18 & 0 & -- & -- & -- \\
\hline
\end{tabular}


Table D. 16 F low Unit calculation with Predicted K for well 15-1132 into two zones.

\begin{tabular}{|c|c|c|c|c|c|c|c|}
\hline $\begin{array}{l}\text { Sample } \\
\text { No. per } \\
\text { Group }\end{array}$ & $\begin{array}{c}\text { Core } \\
\text { Depth, } \\
\text { Ft }\end{array}$ & $\begin{array}{l}\text { Predicted K, } \\
\text { mD }\end{array}$ & $\begin{array}{c}\text { C um.Sum of } K, \\
\mathrm{mD}\end{array}$ & $\begin{array}{c}\text { Grand Sum M inus } \\
\text { Cum. Sum, mD }\end{array}$ & $B, m^{2}$ & $\mathbf{W}, \mathrm{mD}^{2}$ & $\begin{array}{l}\text { Zonation } \\
\text { Index, R }\end{array}$ \\
\hline 1 & 1994.2 & 3.36 & 3.36 & 31.00 & 0.890 & 1.852 & 0.0000 \\
\hline 2 & 1995.6 & 3.72 & 7.08 & 27.28 & 2.755 & 1.697 & 0.3839 \\
\hline 3 & 1997.05 & 3.83 & 10.91 & 23.46 & 5.331 & 1.482 & 0.7220 \\
\hline 4 & 1998.4 & 3.46 & 14.37 & 19.99 & 7.251 & 1.322 & 0.8177 \\
\hline 5 & 1999.8 & 3.32 & 17.69 & 16.68 & 9.116 & 1.167 & 0.8720 \\
\hline 6 & 2001.3 & 3.46 & 21.15 & 13.22 & 12.022 & 0.925 & 0.9231 \\
\hline 7 & 2002.6 & 3.36 & 24.51 & 9.85 & 15.348 & 0.647 & 0.9578 \\
\hline 8 & 2004 & 3.13 & 27.64 & 6.72 & 18.696 & 0.369 & 0.9803 \\
\hline 9 & 2005.4 & 2.29 & 29.93 & 4.44 & 19.108 & 0.334 & 0.9825 \\
\hline$* *$ & $* *$ & $* *$ & $* *$ & $* *$ & $* *$ & $* *$ & $* *$ \\
\hline 10 & 2006.55 & 1.90 & 31.83 & 2.54 & 18.548 & 0.381 & 0.9795 \\
\hline 11 & 2007.7 & 1.47 & 33.29 & 1.07 & 16.793 & 0.527 & 0.9686 \\
\hline 12 & 2009.05 & 0.76 & 34.05 & 0.31 & 12.322 & 0.900 & 0.9270 \\
\hline 13 & 2010.4 & 0.21 & 34.26 & 0.11 & 5.936 & 1.432 & 0.7588 \\
\hline 14 & 2011.55 & 0.11 & 34.36 & 0 & -- & -- & -- \\
\hline
\end{tabular}

Table D. 17 Flow Unit calculation with Predicted K for well 15-1132 into three zones.

\begin{tabular}{|c|c|c|c|c|c|c|c|}
\hline $\begin{array}{l}\text { Sample } \\
\text { No. per } \\
\text { G roup }\end{array}$ & $\begin{array}{c}\text { Core } \\
\text { Depth, } \\
\text { Ft }\end{array}$ & $\begin{array}{l}\text { Predicted K, } \\
\text { mD }\end{array}$ & $\begin{array}{c}\text { Cum.Sum of } K, \\
\text { mD }\end{array}$ & $\begin{array}{l}\text { Grand Sum M inus } \\
\text { Cum. Sum, mD }\end{array}$ & $B, m D^{2}$ & $\mathbf{W}, \mathrm{mD}^{2}$ & $\begin{array}{l}\text { Zonation } \\
\text { Index, R }\end{array}$ \\
\hline \multicolumn{8}{|l|}{ Group 1} \\
\hline 1 & 1994.2 & 3.36 & 3.36 & 26.56 & 9.555 & 0.364 & 0.9619 \\
\hline 2 & 1995.6 & 3.72 & 7.08 & 22.85 & 9.614 & 0.354 & 0.9632 \\
\hline 3 & 1997.05 & 3.83 & 10.91 & 19.02 & 9.772 & 0.325 & 0.9667 \\
\hline 4 & 1998.4 & 3.46 & 14.37 & 15.56 & 9.811 & 0.318 & 0.9676 \\
\hline 5 & 1999.8 & 3.32 & 17.69 & 12.24 & 9.807 & 0.319 & 0.9675 \\
\hline 6 & 2001.3 & 3.46 & 21.15 & 8.78 & 9.911 & 0.300 & 0.9698 \\
\hline 7 & 2002.6 & 3.36 & 24.51 & 5.42 & 10.043 & 0.276 & 0.9726 \\
\hline 8 & 2004 & 3.13 & 27.64 & 2.29 & 10.162 & 0.254 & 0.9750 \\
\hline 9 & 2005.4 & 2.29 & 29.93 & 0 & -- & -- & -- \\
\hline \multicolumn{8}{|l|}{ Group 2} \\
\hline 1 & 2006.55 & 1.90 & 1.90 & 2.54 & 10.192 & 0.249 & 0.9756 \\
\hline 2 & 2007.7 & 1.47 & 3.36 & 1.07 & 10.607 & 0.173 & 0.9837 \\
\hline 3 & 2009.05 & 0.76 & 4.12 & 0.31 & 10.444 & 0.203 & 0.9806 \\
\hline 4 & 2010.4 & 0.21 & 4.33 & 0.11 & 9.935 & 0.295 & 0.9703 \\
\hline 5 & 2011.55 & 0.11 & 4.44 & 0 & -- & -- & -- \\
\hline
\end{tabular}


Table D. 18 F low Unit calculation with Predicted K for well 15-1184 into two zones.

\begin{tabular}{|c|c|c|c|c|c|c|c|}
\hline $\begin{array}{l}\text { Sample } \\
\text { No. per } \\
\text { Group }\end{array}$ & $\begin{array}{c}\text { Core } \\
\text { Depth, } \\
\text { Ft }\end{array}$ & $\begin{array}{l}\text { Predicted K, } \\
\text { mD }\end{array}$ & $\begin{array}{c}\text { Cum.Sum of } K \text {, } \\
\mathrm{mD}\end{array}$ & $\begin{array}{l}\text { G rand Sum M inus } \\
\text { C um. Sum, mD }\end{array}$ & $B, \mathrm{mD}^{2}$ & $\mathrm{~W}, \mathrm{mD}^{2}$ & $\begin{array}{l}\text { Zonation } \\
\text { Index, R }\end{array}$ \\
\hline 1 & 1873 & 1.93 & 1.93 & 121.90 & 9.491 & 3.188 & 0.6641 \\
\hline 2 & 1874 & 4.77 & 6.71 & 117.13 & 5.568 & 3.359 & 0.3967 \\
\hline 3 & 1875 & 5.38 & 12.09 & 111.75 & 2.912 & 3.474 & 0 \\
\hline 4 & 1876 & 4.63 & 16.72 & 107.12 & 2.853 & 3.477 & 0 \\
\hline 5 & 1877 & 5.07 & 21.78 & 102.05 & 2.224 & 3.504 & 0 \\
\hline 6 & 1878 & 6.07 & 27.85 & 95.98 & 0.764 & 3.568 & 0 \\
\hline 7 & 1879 & 6.54 & 34.40 & 89.44 & 0.015 & 3.600 & 0 \\
\hline 8 & 1880 & 7.38 & 41.78 & 82.06 & 0.850 & 3.564 & 0 \\
\hline 9 & 1881 & 7.72 & 49.50 & 74.34 & 4.199 & 3.419 & 0.1859 \\
\hline 10 & 1882 & 6.45 & 55.95 & 67.89 & 6.849 & 3.303 & 0.5177 \\
\hline 11 & 1883 & 7.61 & 63.55 & 60.29 & 13.334 & 3.021 & 0.7734 \\
\hline 12 & 1884 & 7.27 & 70.82 & 53.02 & 20.753 & 2.699 & 0.8700 \\
\hline 13 & 1885 & 6.74 & 77.56 & 46.27 & 27.795 & 2.393 & 0.9139 \\
\hline 14 & 1886 & 6.64 & 84.21 & 39.63 & 35.843 & 2.043 & 0.9430 \\
\hline$* *$ & $* *$ & $* *$ & $* *$ & $* *$ & $* *$ & $* *$ & $* *$ \\
\hline 15 & 1887 & 4.43 & 88.63 & 35.20 & 34.230 & 2.113 & 0.9383 \\
\hline 16 & 1888 & 4.10 & 92.74 & 31.10 & 31.559 & 2.229 & 0.9294 \\
\hline 17 & 1889 & 4.10 & 96.84 & 26.99 & 29.342 & 2.325 & 0.9207 \\
\hline 18 & 1890 & 4.49 & 101.34 & 22.50 & 29.402 & 2.323 & 0.9210 \\
\hline 19 & 1891 & 4.99 & 106.33 & 17.51 & 32.701 & 2.179 & 0.9334 \\
\hline 20 & 1892 & 4.36 & 110.69 & 13.15 & 33.741 & 2.134 & 0.9367 \\
\hline 21 & 1893 & 3.87 & 114.55 & 9.28 & 32.995 & 2.167 & 0.9343 \\
\hline 22 & 1894 & 3.75 & 118.30 & 5.53 & 32.947 & 2.169 & 0.9342 \\
\hline 23 & 1895 & 2.61 & 120.92 & 2.92 & 26.531 & 2.448 & 0.9077 \\
\hline 24 & 1896 & 1.99 & 122.91 & 0.93 & 16.897 & 2.866 & 0.8304 \\
\hline 25 & 1897 & 0.93 & 123.84 & 0 & -- & -- & -- \\
\hline
\end{tabular}


Table D. 19 Flow Unit calculation with Predicted K for well 15-1184 into three zones.

\begin{tabular}{|c|c|c|c|c|c|c|c|}
\hline $\begin{array}{l}\text { Sample } \\
\text { No. per } \\
\text { Group }\end{array}$ & $\begin{array}{c}\text { Core } \\
\text { Depth, } \\
\text { Ft }\end{array}$ & $\begin{array}{l}\text { Predicted K, } \\
\text { mD }\end{array}$ & $\begin{array}{c}\text { Cum.Sum of } K, \\
\mathrm{mD}\end{array}$ & $\begin{array}{l}\text { Grand Sum Minus } \\
\text { C um. Sum, mD }\end{array}$ & $B, m^{2}$ & $\mathrm{~W}, \mathrm{mD}^{2}$ & $\begin{array}{l}\text { Zonation } \\
\text { Index, R }\end{array}$ \\
\hline \multicolumn{8}{|l|}{ Group 1} \\
\hline 1 & 1873 & 1.93 & 1.93 & 82.27 & 26.884 & 1.321 & 0.9509 \\
\hline 2 & 1874 & 4.77 & 6.71 & 77.50 & 26.187 & 1.384 & 0.9471 \\
\hline 3 & 1875 & 5.38 & 12.09 & 72.12 & 25.448 & 1.451 & 0.9430 \\
\hline 4 & 1876 & 4.63 & 16.72 & 67.49 & 27.354 & 1.278 & 0.9433 \\
\hline 5 & 1877 & 5.07 & 21.78 & 62.42 & 28.611 & 1.164 & 0.9473 \\
\hline 6 & 1878 & 6.07 & 27.85 & 56.35 & 27.811 & 1.237 & 0.9455 \\
\hline 7 & 1879 & 6.54 & 34.40 & 49.81 & 26.405 & 1.364 & 0.9483 \\
\hline 8 & 1880 & 7.38 & 41.78 & 42.43 & 23.784 & 1.603 & 0.9326 \\
\hline 9 & 1881 & 7.72 & 49.50 & 34.71 & 21.262 & 1.832 & 0.9138 \\
\hline 10 & 1882 & 6.45 & 55.95 & 28.26 & 21.013 & 1.855 & 0.9117 \\
\hline 11 & 1883 & 7.61 & 63.55 & 20.66 & 19.369 & 2.004 & 0.8965 \\
\hline 12 & 1884 & 7.27 & 70.82 & 13.39 & 18.458 & 2.087 & 0.8869 \\
\hline 13 & 1885 & 6.74 & 77.56 & 6.64 & 18.134 & 2.116 & 0.8833 \\
\hline 14 & 1886 & 6.64 & 84.21 & 0 & -- & -- & -- \\
\hline \multicolumn{8}{|l|}{ Group 2} \\
\hline 1 & 1887 & 4.43 & 4.43 & 35.20 & 18.294 & 2.102 & 0.8851 \\
\hline 2 & 1888 & 4.10 & 8.53 & 31.10 & 18.458 & 2.087 & 0.8869 \\
\hline 3 & 1889 & 4.10 & 12.64 & 26.99 & 18.687 & 2.066 & 0.8894 \\
\hline 4 & 1890 & 4.49 & 17.13 & 22.50 & 19.372 & 2.004 & 0.8966 \\
\hline 5 & 1891 & 4.99 & 22.12 & 17.51 & 21.013 & 1.855 & 0.9117 \\
\hline 6 & 1892 & 4.36 & 26.48 & 13.15 & 22.257 & 1.741 & 0.9218 \\
\hline 7 & 1893 & 3.87 & 30.34 & 9.28 & 23.082 & 1.666 & 0.9278 \\
\hline 8 & 1894 & 3.75 & 34.09 & 5.53 & 24.295 & 1.556 & 0.9359 \\
\hline 9 & 1895 & 2.61 & 36.71 & 2.92 & 23.533 & 1.625 & 0.9309 \\
\hline 10 & 1896 & 1.99 & 38.70 & 0.93 & 21.862 & 1.777 & 0.9187 \\
\hline 11 & 1897 & 0.93 & 39.63 & 0 & -- & -- & -- \\
\hline
\end{tabular}


Table D. 20 F low Unit calculation with Predicted K for well 15-1309 into two zones.

\begin{tabular}{|c|c|c|c|c|c|c|c|}
\hline $\begin{array}{l}\text { Sample } \\
\text { No. per } \\
\text { Group }\end{array}$ & $\begin{array}{c}\text { Core } \\
\text { Depth, } \\
\text { Ft }\end{array}$ & $\begin{array}{l}\text { Predicted K, } \\
\text { mD }\end{array}$ & $\begin{array}{c}\text { Cum.Sum of } K \text {, } \\
\mathrm{mD}\end{array}$ & $\begin{array}{l}\text { Grand Sum M inus } \\
\text { Cum. Sum, mD }\end{array}$ & $B, m^{2}$ & $\mathbf{W}, \mathrm{mD}^{2}$ & $\begin{array}{l}\text { Zonation } \\
\text { Index, R }\end{array}$ \\
\hline \multirow{4}{*}{$\begin{array}{l}1 \\
2 \\
3\end{array}$} & 1961.5 & 0.21 & 0.21 & 54.74 & 11.114 & 4.442 & 0.6003 \\
\hline & 1962.5 & 0.74 & 0.95 & 54.00 & 20.033 & 3.805 & 0.8101 \\
\hline & 1963.5 & 1.65 & 2.60 & 52.34 & 24.327 & 3.499 & 0.8562 \\
\hline & $* *$ & $* *$ & $* *$ & $* *$ & $* *$ & $* *$ & $* *$ \\
\hline 4 & 1964.5 & 2.91 & 5.51 & 49.43 & 22.534 & 3.627 & 0.8391 \\
\hline 5 & 1965.5 & 4.16 & 9.68 & 45.27 & 16.337 & 4.069 & 0.7509 \\
\hline 6 & 1966.5 & 5.69 & 15.36 & 39.58 & 7.320 & 4.713 & 0.3561 \\
\hline 7 & 1967.5 & 7.01 & 22.37 & 32.57 & 0.706 & 5.186 & 0 \\
\hline 8 & 1968.5 & 5.60 & 27.98 & 26.97 & 0.063 & 5.232 & 0 \\
\hline 9 & 1969.5 & 5.60 & 33.58 & 21.36 & 1.816 & 5.106 & 0 \\
\hline 10 & 1970.5 & 4.76 & 38.34 & 16.61 & 4.264 & 4.932 & 0 \\
\hline 11 & 1971.5 & 3.81 & 42.15 & 12.80 & 5.558 & 4.839 & 0.1294 \\
\hline 12 & 1972.5 & 3.53 & 45.68 & 9.27 & 6.663 & 4.760 & 0.2856 \\
\hline 13 & 1973.5 & 4.69 & 50.37 & 4.58 & 13.447 & 4.276 & 0.6820 \\
\hline 14 & 1974.5 & 4.10 & 54.47 & 0.48 & 23.346 & 3.569 & 0.8471 \\
\hline 15 & 1980.5 & 0.40 & 54.86 & 0.08 & 12.003 & 4.379 & 0.6352 \\
\hline 16 & 1981.5 & 0.08 & 54.94 & 0 & -- & -- & -- \\
\hline
\end{tabular}

Table D. 21 Flow Unit calculation with Predicted K for well 15-1309 into three zones.

\begin{tabular}{|c|c|c|c|c|c|c|c|}
\hline $\begin{array}{l}\text { Sample } \\
\text { No. per } \\
\text { Group }\end{array}$ & $\begin{array}{c}\text { Core } \\
\text { Depth, } \\
\text { Ft }\end{array}$ & $\begin{array}{l}\text { Predicted K, } \\
\text { mD }\end{array}$ & $\begin{array}{c}\text { Cum.Sum of } K \text {, } \\
\mathrm{mD}\end{array}$ & $\begin{array}{l}\text { Grand Sum M inus } \\
\text { C um. Sum, mD }\end{array}$ & $B, m^{2}$ & $\mathrm{~W}, \mathrm{mD}^{2}$ & $\begin{array}{l}\text { Zonation } \\
\text { Index, R }\end{array}$ \\
\hline \multicolumn{8}{|l|}{ Group 1} \\
\hline 1 & 1961.5 & 0.21 & 0.21 & 2.40 & 12.491 & 3.717 & 0.7024 \\
\hline 2 & 1962.5 & 0.74 & 0.95 & 1.65 & 12.628 & 3.696 & 0.7073 \\
\hline 3 & 1963.5 & 1.65 & 2.60 & 0 & -- & -- & -- \\
\hline \multicolumn{8}{|l|}{ Group 2} \\
\hline 1 & 1964.5 & 2.91 & 2.91 & 49.43 & 12.835 & 3.664 & 0.7145 \\
\hline 2 & 1965.5 & 4.16 & 7.07 & 45.27 & 12.446 & 3.724 & 0.7008 \\
\hline 3 & 1966.5 & 5.69 & 12.76 & 39.58 & 12.265 & 3.752 & 0.6941 \\
\hline 4 & 1967.5 & 7.01 & 19.77 & 32.57 & 14.587 & 3.395 & 0.7673 \\
\hline 5 & 1968.5 & 5.60 & 25.37 & 26.97 & 16.629 & 3.081 & 0.8147 \\
\hline 6 & 1969.5 & 5.60 & 30.98 & 21.36 & 19.362 & 2.660 & 0.8626 \\
\hline 7 & 1970.5 & 4.76 & 35.74 & 16.61 & 20.991 & 2.410 & 0.8852 \\
\hline 8 & 1971.5 & 3.81 & 39.54 & 12.80 & 20.901 & 2.423 & 0.8841 \\
\hline 9 & 1972.5 & 3.53 & 43.08 & 9.27 & 20.611 & 2.468 & 0.8803 \\
\hline 10 & 1973.5 & 4.69 & 47.77 & 4.58 & 24.358 & 1.892 & 0.9223 \\
\hline 11 & 1974.5 & 4.10 & 51.87 & 0.48 & 29.123 & 1.158 & 0.9602 \\
\hline$* *$ & $* *$ & $* *$ & $* *$ & $* *$ & $* *$ & $* *$ & $* *$ \\
\hline 12 & 1980.5 & 0.40 & 52.26 & 0.08 & 20.601 & 2.470 & 0.8801 \\
\hline 13 & 1981.5 & 0.08 & 52.34 & 0 & -- & -- & -- \\
\hline
\end{tabular}


Table D. 22 F low Unit calculation with Predicted K for well 15-1309 into four zones.

\begin{tabular}{|c|c|c|c|c|c|c|c|}
\hline $\begin{array}{c}\text { Sample } \\
\text { No. per } \\
\text { Group }\end{array}$ & $\begin{array}{c}\text { Core } \\
\text { Depth, } \\
\text { Ft }\end{array}$ & $\begin{array}{l}\text { Predicted K, } \\
\text { mD }\end{array}$ & $\begin{array}{c}\text { Cum.Sum of } K \text {, } \\
\mathrm{mD}\end{array}$ & $\begin{array}{l}\text { Grand Sum Minus } \\
\text { Cum. Sum, mD }\end{array}$ & $B, m D^{2}$ & $\mathrm{~W}, \mathrm{mD}^{2}$ & $\begin{array}{l}\text { Zonation } \\
\text { Index, R }\end{array}$ \\
\hline \multicolumn{8}{|l|}{ Group 1} \\
\hline 1 & 1961.5 & 0.21 & 0.21 & 2.40 & 12.491 & 3.717 & 0.7024 \\
\hline 2 & 1962.5 & 0.74 & 0.95 & 1.65 & 12.628 & 3.696 & 0.7073 \\
\hline 3 & 1963.5 & 1.65 & 2.60 & 0 & -- & -- & -- \\
\hline \multicolumn{8}{|l|}{ Group 2} \\
\hline 1 & 1964.5 & 2.91 & 2.91 & 48.95 & 29.783 & 1.057 & 0.9645 \\
\hline 2 & 1965.5 & 4.16 & 7.07 & 44.79 & 29.691 & 1.071 & 0.9639 \\
\hline 3 & 1966.5 & 5.69 & 12.76 & 39.10 & 28.433 & 1.265 & 0.9555 \\
\hline 4 & 1967.5 & 7.01 & 19.77 & 32.10 & 28.158 & 1.307 & 0.9536 \\
\hline 5 & 1968.5 & 5.60 & 25.37 & 26.49 & 28.588 & 1.241 & 0.9566 \\
\hline 6 & 1969.5 & 5.60 & 30.98 & 20.89 & 29.320 & 1.128 & 0.9615 \\
\hline 7 & 1970.5 & 4.76 & 35.74 & 16.13 & 29.461 & 1.107 & 0.9624 \\
\hline 8 & 1971.5 & 3.81 & 39.54 & 12.32 & 28.757 & 1.215 & 0.9578 \\
\hline 9 & 1972.5 & 3.53 & 43.08 & 8.79 & 28.121 & 1.313 & 0.9533 \\
\hline 10 & 1973.5 & 4.69 & 47.77 & 4.10 & 28.203 & 1.300 & 0.9539 \\
\hline 11 & 1974.5 & 4.10 & 51.87 & 0 & -- & -- & -- \\
\hline \multicolumn{8}{|l|}{ Group 3} \\
\hline 1 & 1980.5 & 0.40 & 0.40 & 0.08 & 28.020 & 1.328 & 0.9526 \\
\hline 2 & 1981.5 & 0.08 & 0.48 & 0 & -- & -- & -- \\
\hline
\end{tabular}




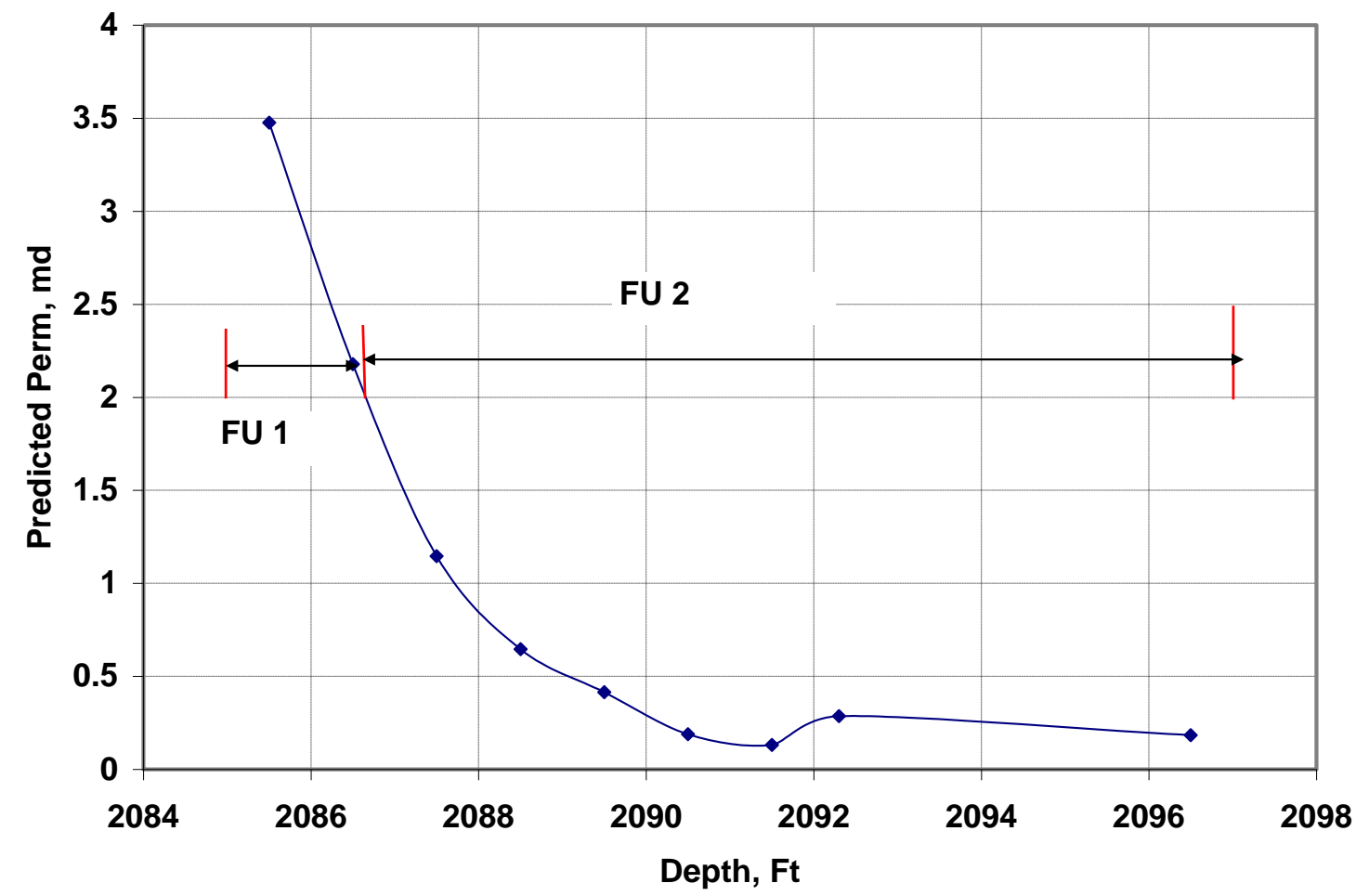

Figure D. 1 Flow Unit identification with predicted permeability in well 15-733.

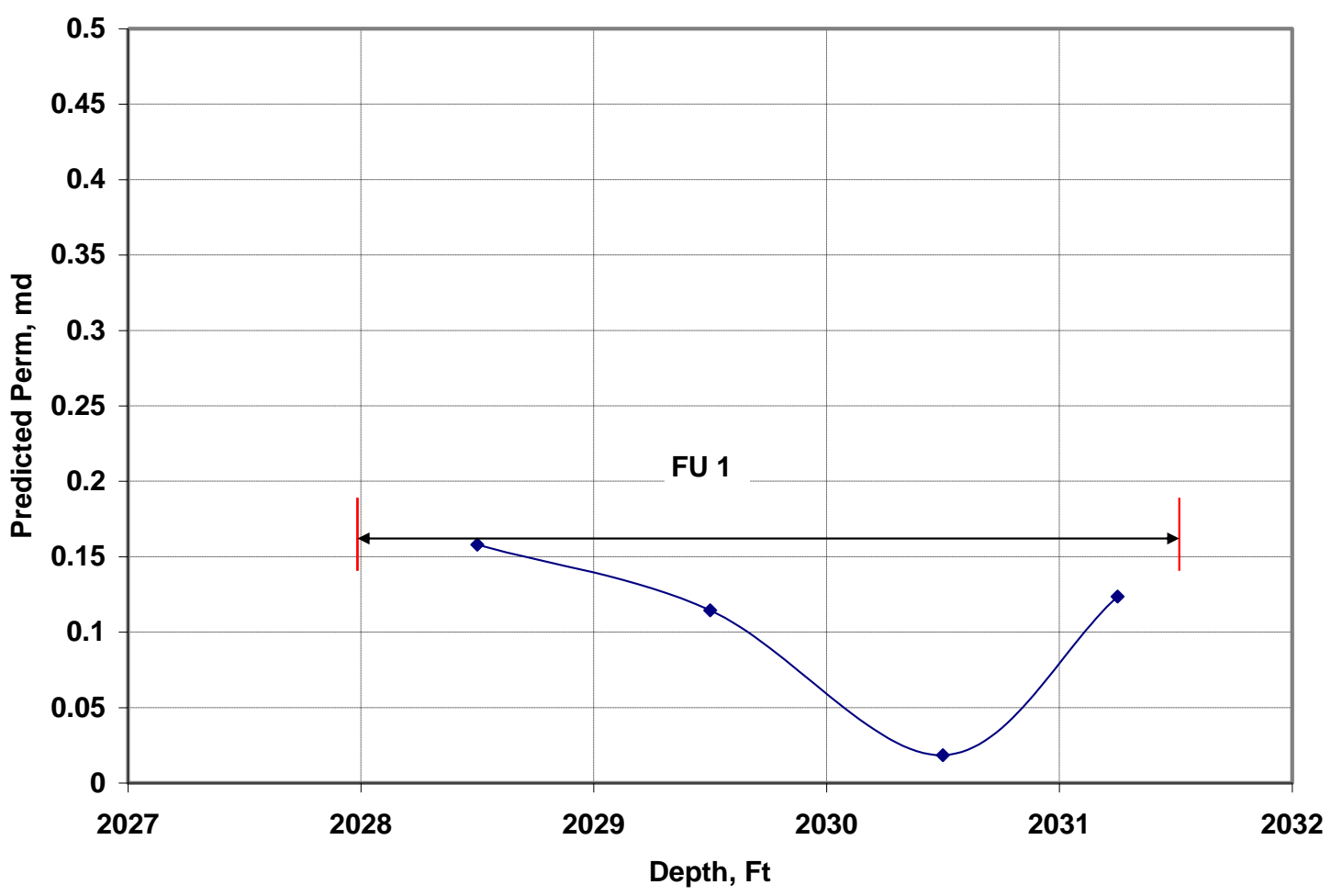

Figure D. 2 Flow U nit identification with predicted permeability in well 15-1059. 


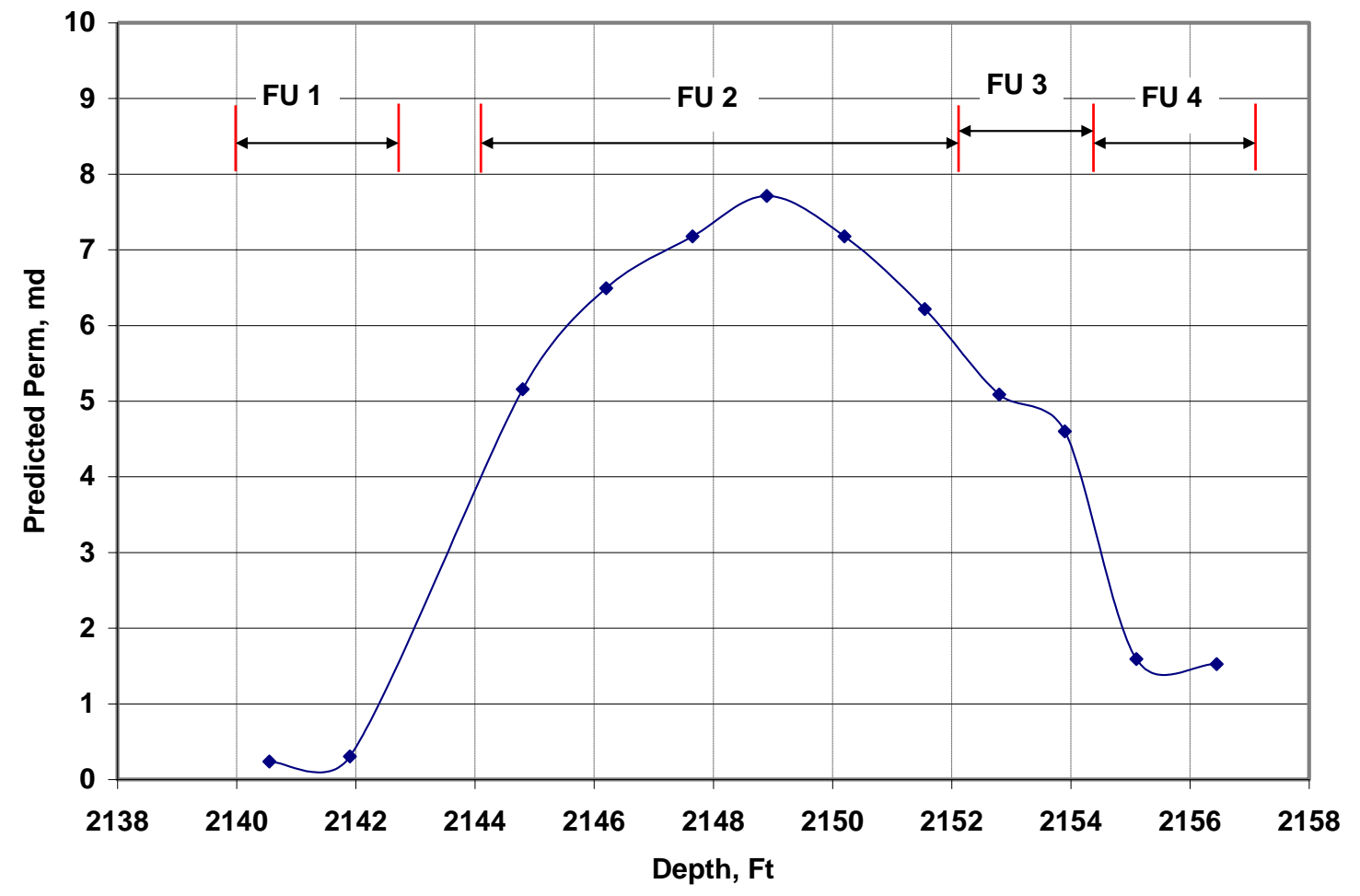

Figure D. 3 Flow Unit identification with predicted permeability in well 15-1107.

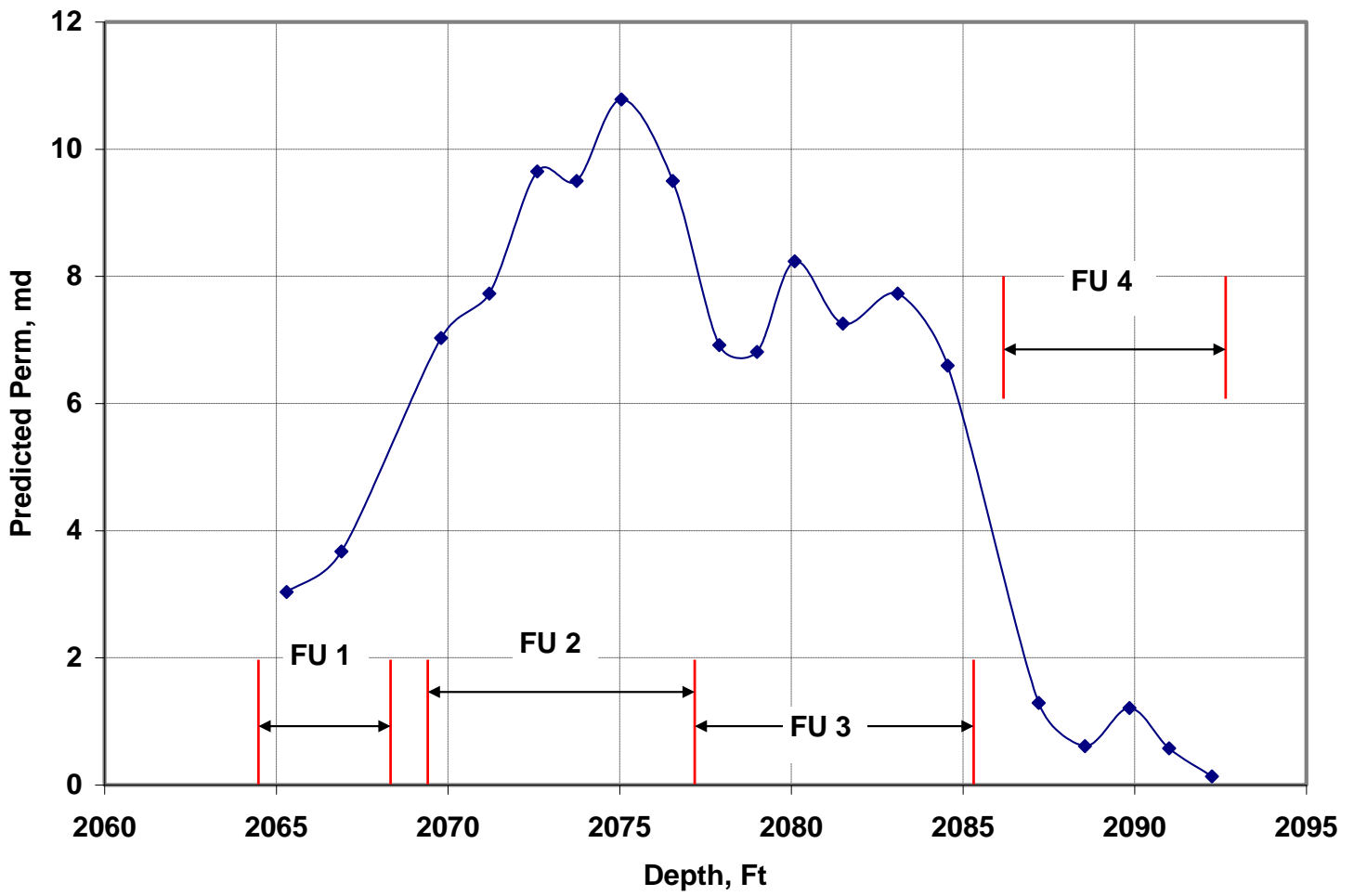

Figure D. 4 Flow U nit identification with predicted permeability in well 15-1108. 


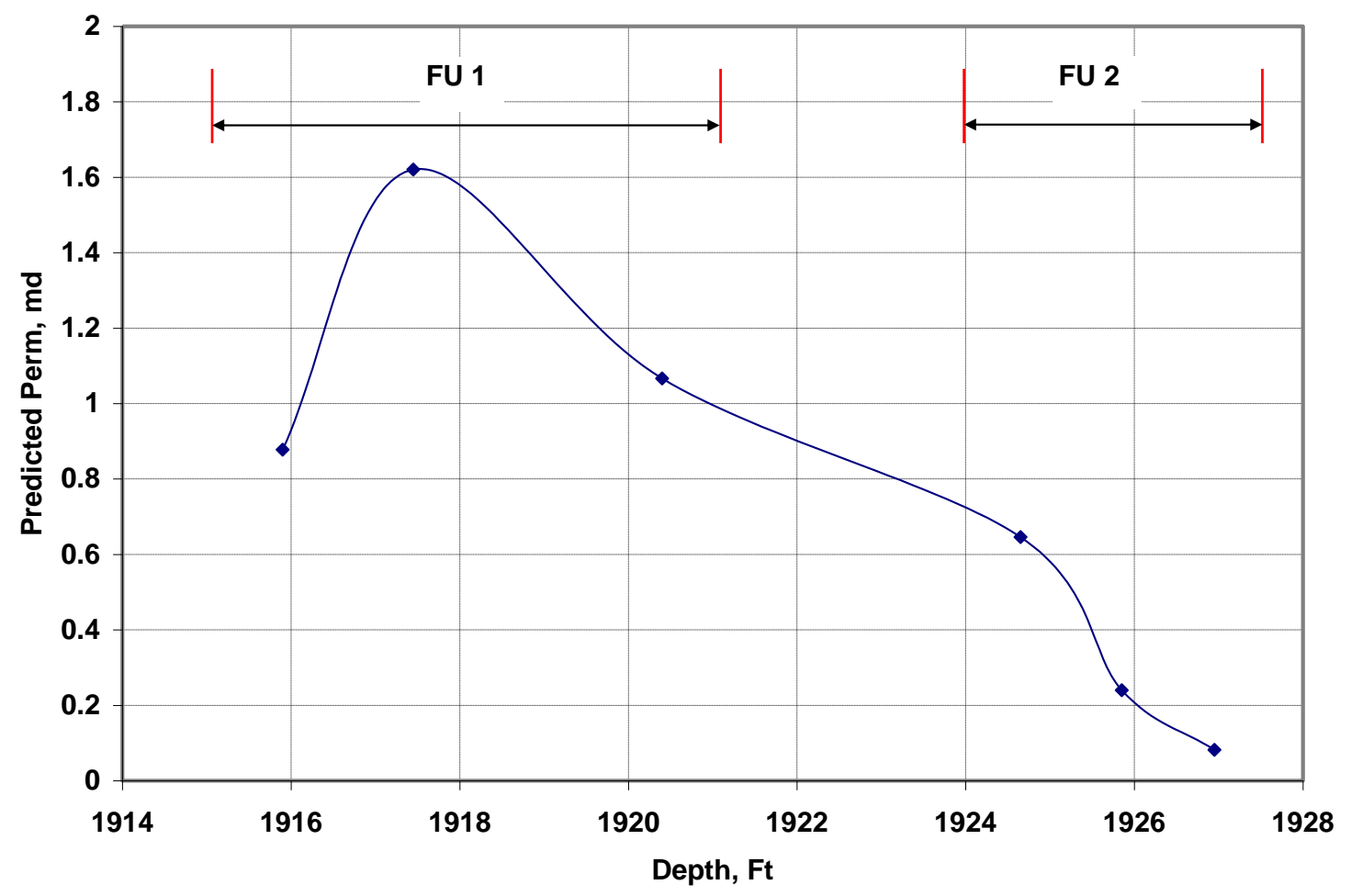

Figure D. 5 Flow U nit identification with predicted permeability in well 15-1109.

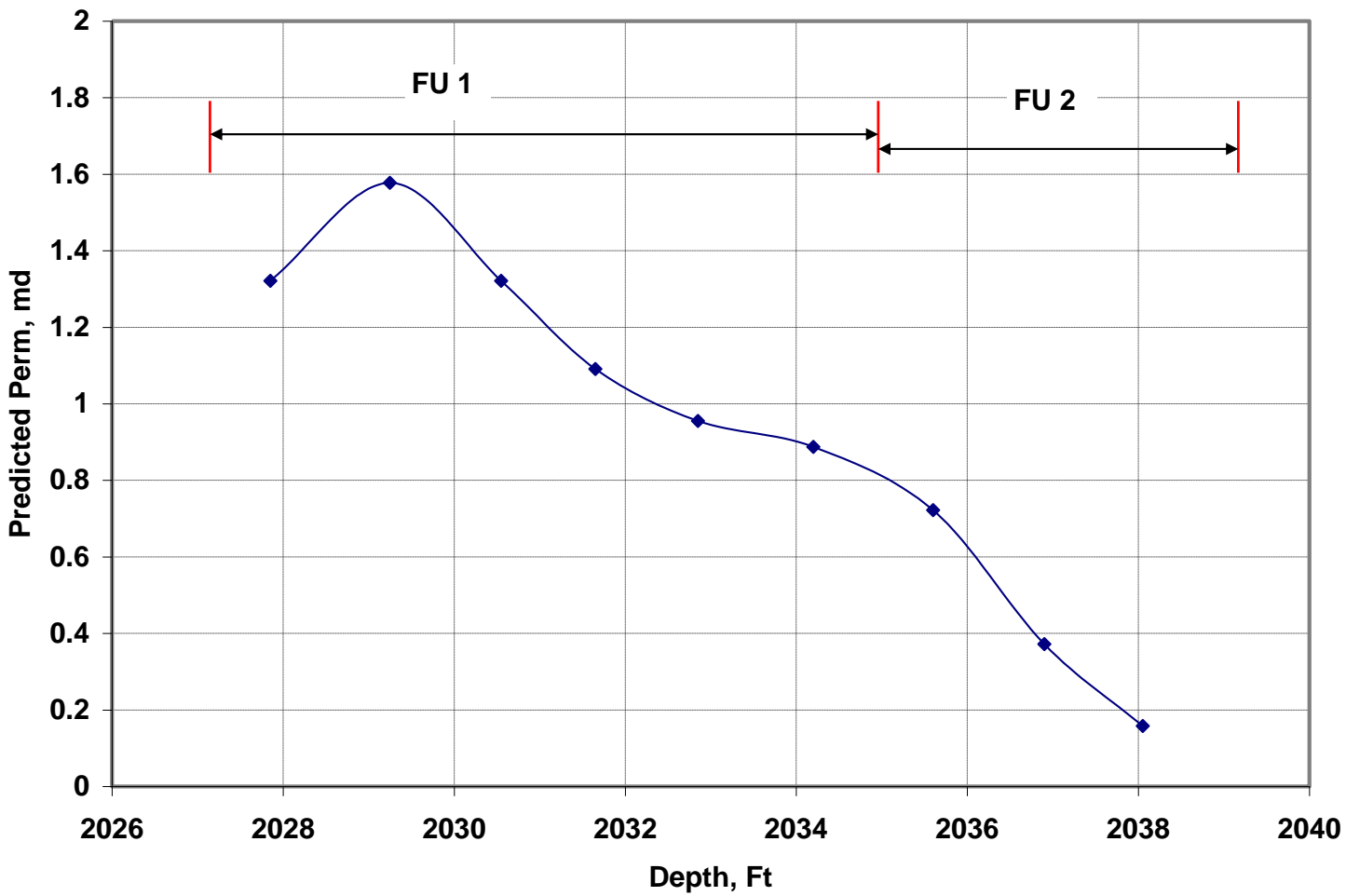

Figure D. 6 Flow U nit identification with predicted permeability in well 15-1128. 


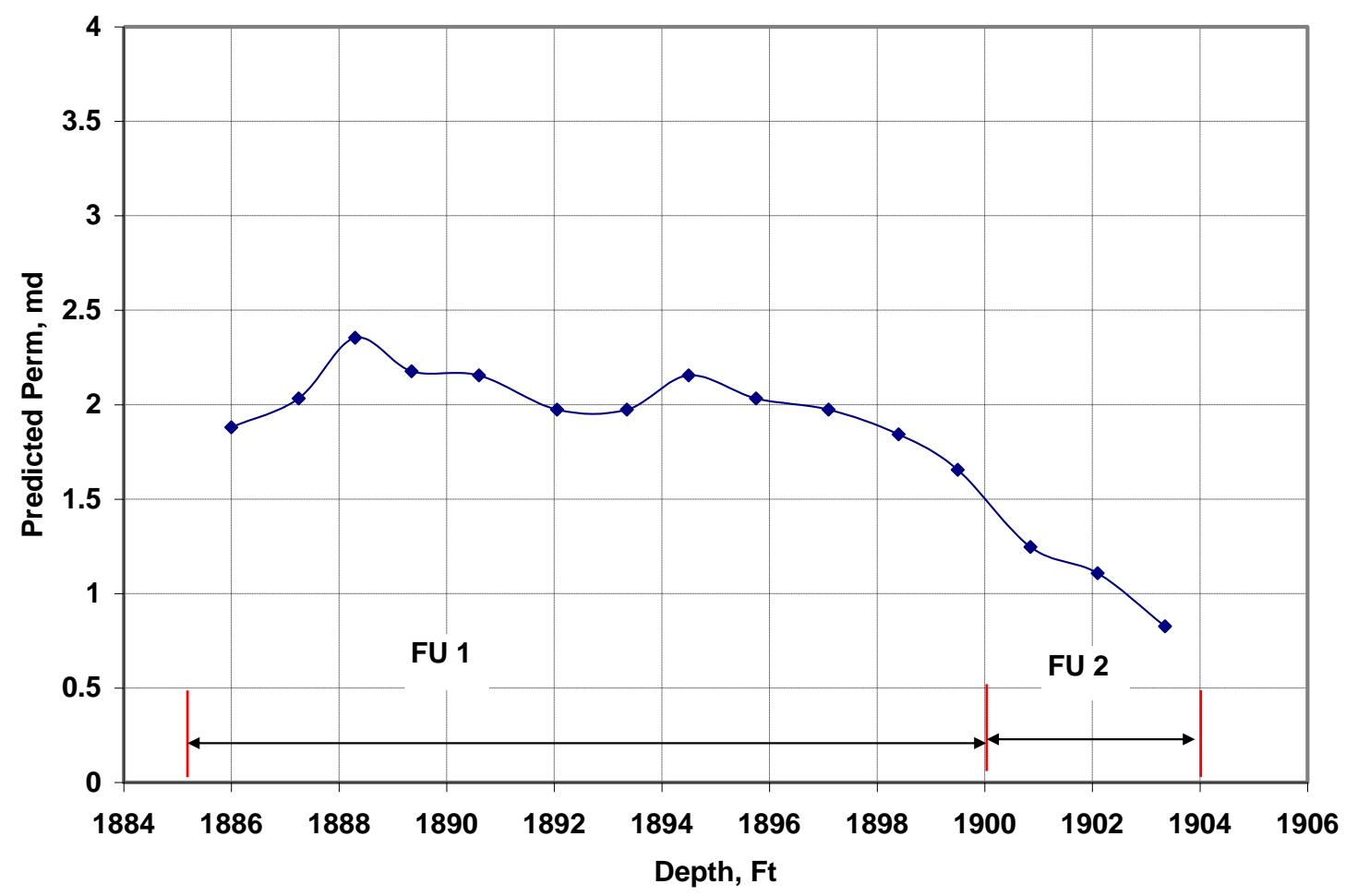

Figure D. 7 Flow Unit identification with predicted permeability in well 15-1130.

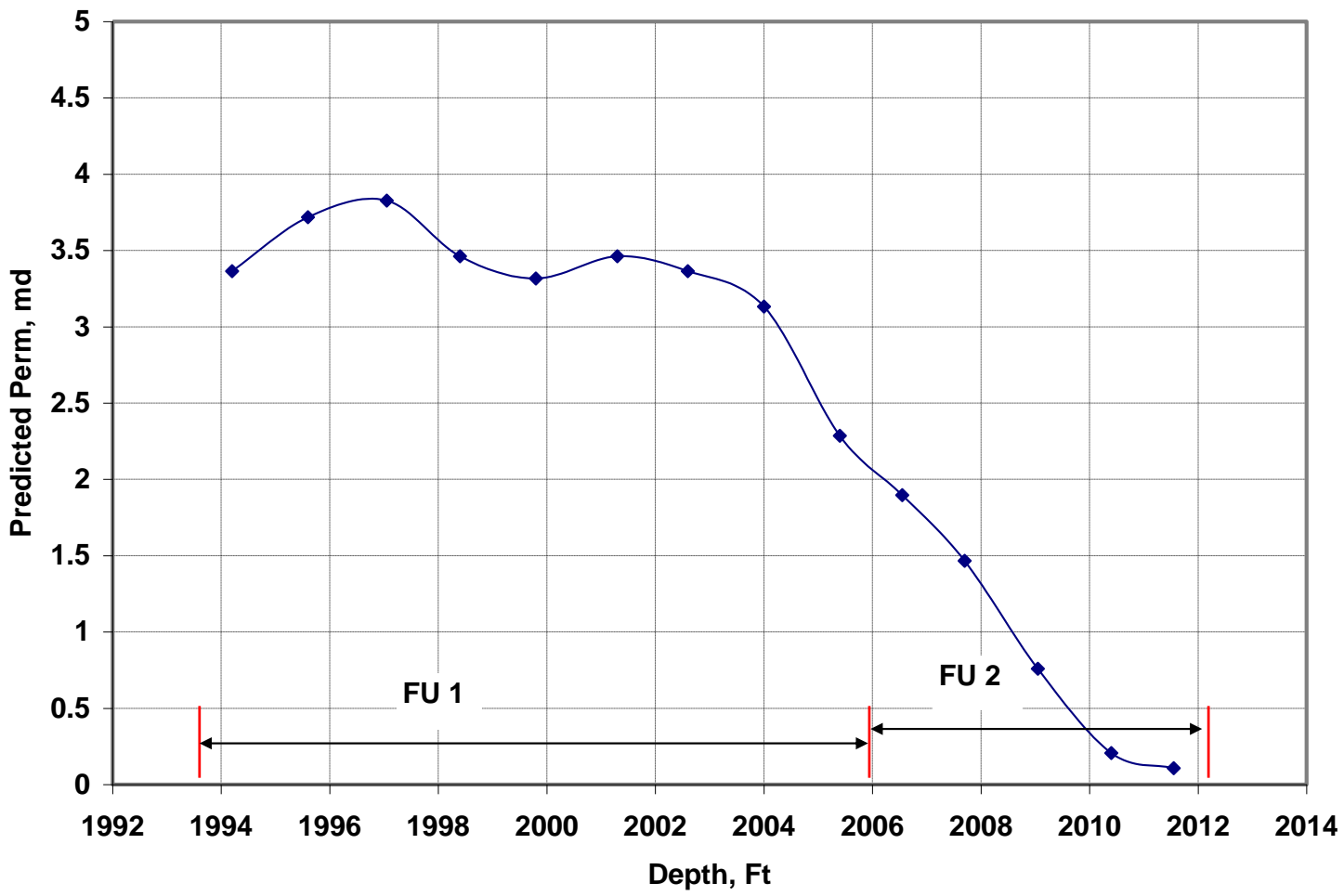

Figure D. 8 F low U nit identification with predicted permeability in well 15-1132. 


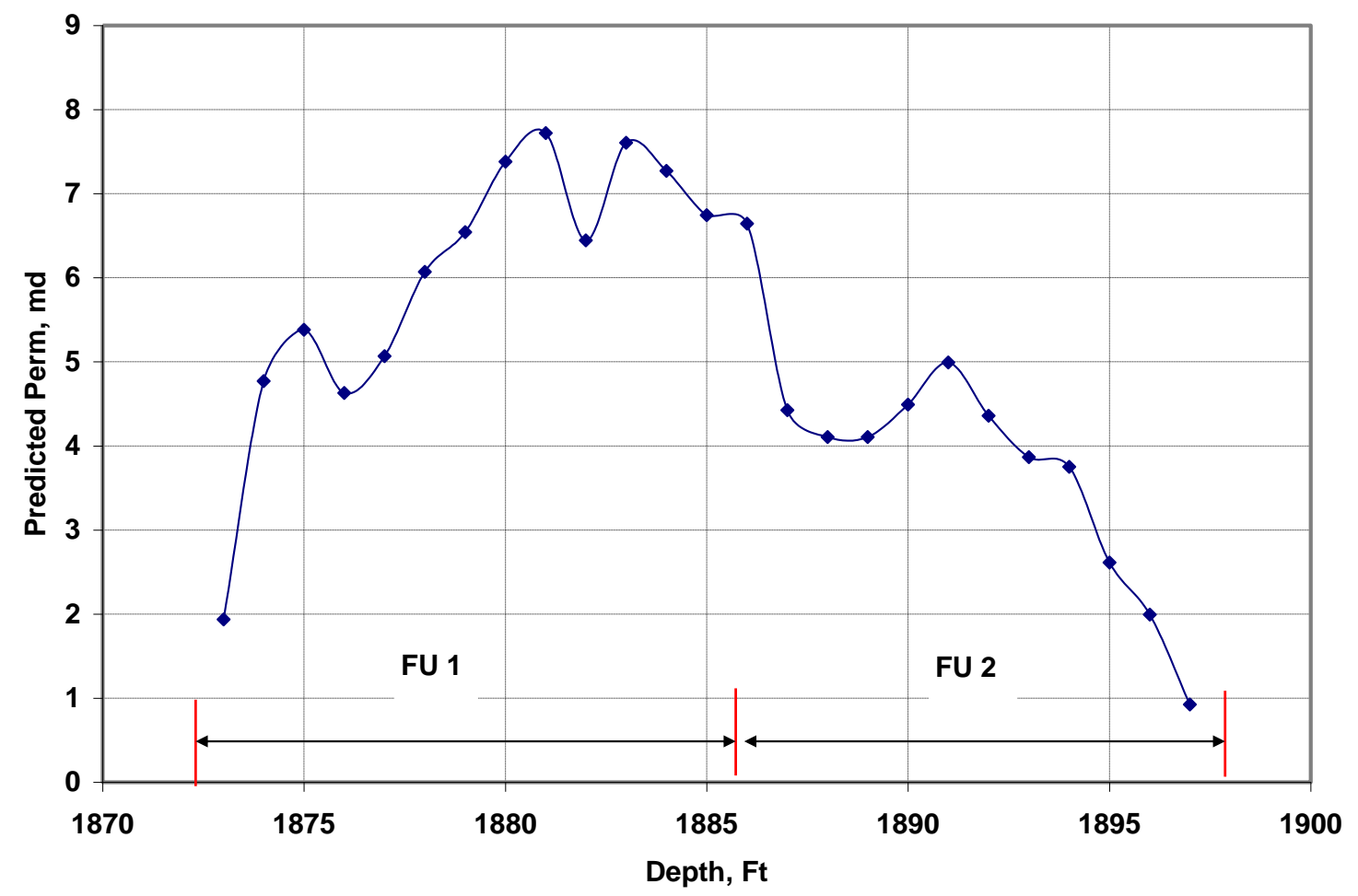

Figure D. 9 Flow Unit identification with predicted permeability in well 15-1184.

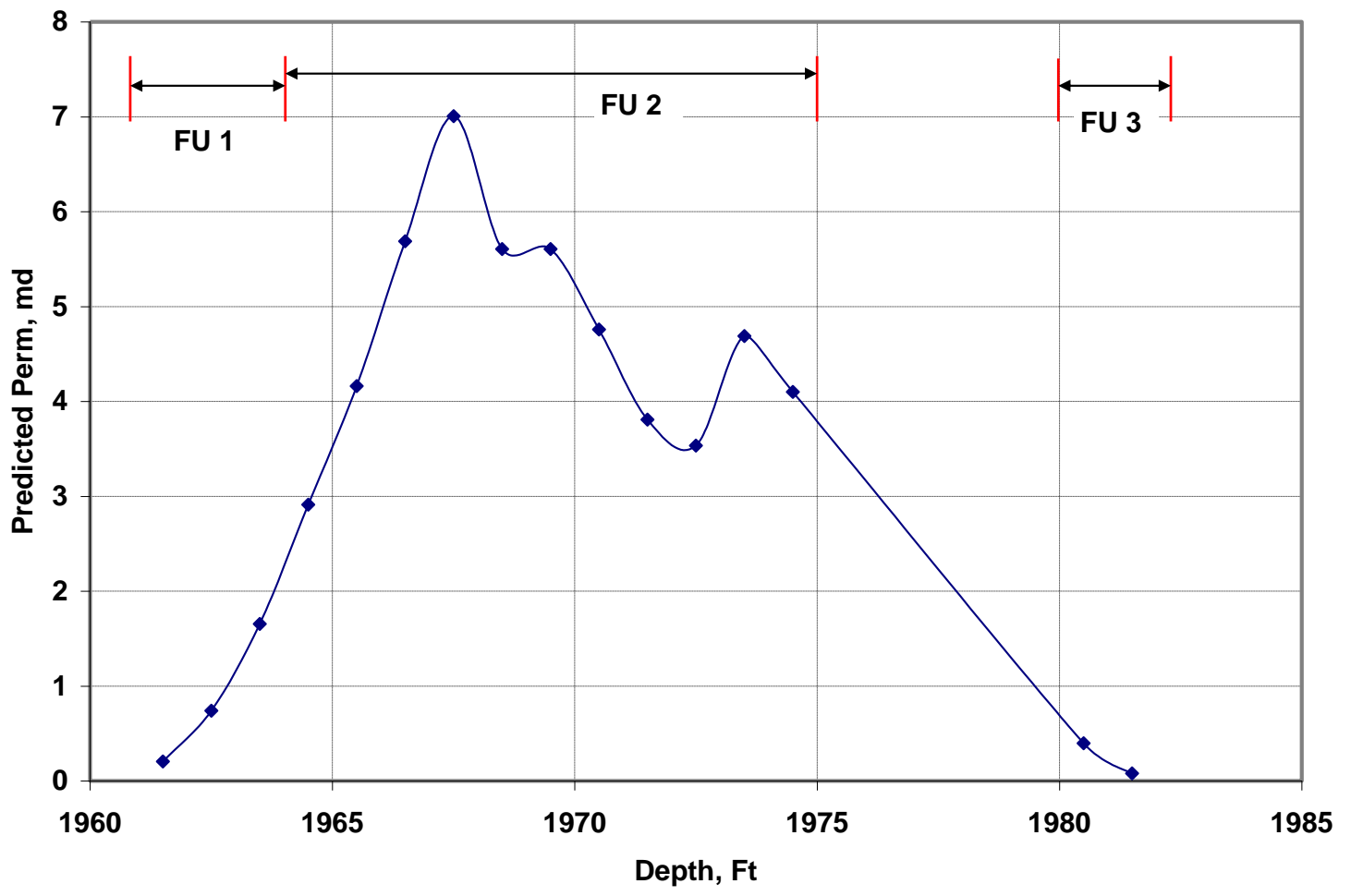

Figure D. 10 F low Unit identification with predicted permeability in well 15-1309. 


\section{APPE NDIX E. \\ Determination of F low Unit by Statistical Z onation Technique using predicted permeability for Uncored W ells.}


Table E . 1 Flow U nit calculation with Predicted K for well 15-868 into two zones.

\begin{tabular}{|c|c|c|c|c|c|c|c|}
\hline $\begin{array}{c}\text { Sample } \\
\text { No. per } \\
\text { Group }\end{array}$ & $\begin{array}{l}\text { Depth, } \\
\text { Ft }\end{array}$ & $\begin{array}{l}\text { Predicted K, } \\
\text { mD }\end{array}$ & $\begin{array}{c}\text { Cum.Sum of } K, \\
\text { mD }\end{array}$ & $\begin{array}{l}\text { G rand Sum M inus } \\
\text { C um. Sum, mD }\end{array}$ & $B, m^{2}$ & $W, m^{2}$ & $\begin{array}{l}\text { Zonation } \\
\text { Index, R }\end{array}$ \\
\hline 1 & 1959 & 1.44 & 1.44 & 11.76 & 0.063 & 0.347 & 0 \\
\hline 2 & 1960 & 2.74 & 2.74 & 10.46 & 0.070 & 0.346 & 0 \\
\hline 3 & 1961 & 4.64 & 4.64 & 8.56 & 0.495 & 0.299 & 0.3959 \\
\hline 4 & 1962 & 6.51 & 6.51 & 6.69 & 1.152 & 0.226 & 0.8035 \\
\hline 5 & 1963 & 8.06 & 8.06 & 5.14 & 1.557 & 0.181 & 0.8837 \\
\hline 6 & 1964 & 9.42 & 9.42 & 3.78 & 1.805 & 0.154 & 0.9149 \\
\hline 7 & 1965 & 10.59 & 10.59 & 2.61 & 1.887 & 0.144 & 0.9235 \\
\hline 8 & 1966 & 11.85 & 11.85 & 1.35 & 2.329 & 0.095 & 0.9590 \\
\hline$* *$ & $* *$ & $* *$ & $* *$ & $* *$ & $* *$ & $* *$ & $* *$ \\
\hline 9 & 1967 & 12.72 & 12.72 & 0.48 & 2.247 & 0.105 & 0.9535 \\
\hline 10 & 1968 & 13.15 & 13.15 & 0.05 & 1.460 & 0.192 & 0.8685 \\
\hline 11 & 1969 & 13.20 & 13.20 & 0 & -- & -- & -- \\
\hline
\end{tabular}

Table E. 2 Flow Unit calculation with Predicted K for well 15-868 into three zones.

\begin{tabular}{|c|c|c|c|c|c|c|c|}
\hline $\begin{array}{l}\text { Sample } \\
\text { No. per } \\
\text { Group }\end{array}$ & $\begin{array}{l}\text { Depth, } \\
\text { Ft }\end{array}$ & $\begin{array}{l}\text { Predicted K, } \\
\text { mD }\end{array}$ & $\begin{array}{c}\text { Cum.Sum of } K \text {, } \\
\text { mD }\end{array}$ & $\begin{array}{l}\text { G rand Sum M inus } \\
\text { C um. Sum, mD }\end{array}$ & $B, m^{2}$ & $\mathrm{~W}, \mathrm{mD}^{2}$ & $\begin{array}{l}\text { Zonation } \\
\text { Index, R }\end{array}$ \\
\hline \multicolumn{8}{|l|}{ Group1 } \\
\hline 1 & 1959 & 1.44 & 1.44 & 10.41 & 1.165 & 0.107 & 0.9081 \\
\hline 2 & 1960 & 1.30 & 2.74 & 9.11 & 1.181 & 0.103 & 0.9127 \\
\hline 3 & 1961 & 1.90 & 4.64 & 7.21 & 1.174 & 0.105 & 0.9108 \\
\hline 4 & 1962 & 1.87 & 6.51 & 5.34 & 1.250 & 0.086 & 0.9312 \\
\hline 5 & 1963 & 1.55 & 8.06 & 3.79 & 1.278 & 0.079 & 0.9382 \\
\hline 6 & 1964 & 1.36 & 9.42 & 2.44 & 1.257 & 0.084 & 0.9331 \\
\hline 7 & 1965 & 1.17 & 10.59 & 1.26 & 1.192 & 0.100 & 0.9157 \\
\hline 8 & 1966 & 1.26 & 11.85 & 0 & -- & -- & -- \\
\hline
\end{tabular}


Table E. 3 F low U nit calculation with Predicted K for well 15-874 into two zones.

\begin{tabular}{|c|c|c|c|c|c|c|c|}
\hline $\begin{array}{l}\text { Sample } \\
\text { No. per } \\
\text { G roup }\end{array}$ & $\begin{array}{l}\text { Depth, } \\
\text { Ft }\end{array}$ & $\begin{array}{l}\text { Predicted K, } \\
\text { mD }\end{array}$ & $\underset{\mathrm{mD}}{\text { Cum.Sum of } K \text {, }}$ & $\begin{array}{l}\text { Grand Sum M inus } \\
\text { Cum. Sum, mD }\end{array}$ & $B, m D^{2}$ & $\mathrm{~W}, \mathrm{mD}^{2}$ & $\begin{array}{l}\text { Zonation } \\
\text { Index, R }\end{array}$ \\
\hline 1 & 1850 & 0.61 & 0.61 & 2.55 & 0.144 & 0.038 & 0.7350 \\
\hline 2 & 1851 & 0.61 & 1.22 & 1.95 & 0.314 & 0.023 & 0.9278 \\
\hline 3 & 1852 & 0.61 & 1.82 & 1.34 & 0.518 & 0.004 & 0.9920 \\
\hline$* *$ & $* *$ & $* *$ & $* *$ & $* *$ & $* *$ & $* *$ & $* *$ \\
\hline 4 & 1853 & 0.19 & 2.01 & 1.15 & 0.390 & 0.016 & 0.9595 \\
\hline 5 & 1854 & 0.09 & 2.10 & 1.06 & 0.256 & 0.028 & 0.8905 \\
\hline 6 & 1855 & 0.02 & 2.13 & 1.03 & 0.138 & 0.039 & 0.7202 \\
\hline 7 & 1856 & 0.09 & 2.22 & 0.94 & 0.082 & 0.044 & 0.4692 \\
\hline 8 & 1857 & 0.29 & 2.51 & 0.65 & 0.104 & 0.042 & 0.5980 \\
\hline 9 & 1858 & 0.16 & 2.67 & 0.49 & 0.085 & 0.044 & 0.4889 \\
\hline 10 & 1859 & 0.12 & 2.80 & 0.37 & 0.057 & 0.046 & 0.1991 \\
\hline 11 & 1860 & 0.12 & 2.92 & 0.24 & 0.035 & 0.048 & 0 \\
\hline 12 & 1861 & 0.12 & 3.04 & 0.12 & 0.016 & 0.050 & 0 \\
\hline 13 & 1862 & 0.12 & 3.16 & 0 & -- & -- & -- \\
\hline
\end{tabular}

Table E. 4 Flow Unit calculation with Predicted K for well 15-1110 into two zones.

\begin{tabular}{cccccccc}
$\begin{array}{c}\text { Sample } \\
\text { No. per } \\
\text { G roup }\end{array}$ & $\begin{array}{c}\text { Depth, } \\
\text { Ft }\end{array}$ & $\begin{array}{c}\text { Predicted K, } \\
\text { mD }\end{array}$ & $\begin{array}{c}\text { C um.Sum of K, G rand Sum Minus } \\
\text { mD }\end{array}$ & $\begin{array}{c}\text { C um. Sum, mD } \\
\text { B, } \mathbf{~ m D}^{\mathbf{2}}\end{array}$ & $\mathbf{~ W , ~} \mathbf{m D}^{\mathbf{2}}$ & $\begin{array}{c}\text { Zonation } \\
\text { Index, R }\end{array}$ \\
\hline 1 & 1934 & 0.59 & 0.59 & 2.90 & 0.065 & 0.058 & 0.0968 \\
2 & 1935 & 0.73 & 1.33 & 2.16 & 0.246 & 0.036 & 0.8545 \\
3 & 1936 & 0.53 & 1.86 & 1.63 & 0.313 & 0.027 & 0.9127 \\
$* *$ & $* *$ & $* *$ & $* *$ & $* *$ & $* *$ & $* *$ & $* *$ \\
4 & 1937 & 0.05 & 1.91 & 1.58 & 0.110 & 0.053 & 0.5200 \\
5 & 1938 & 0.06 & 1.97 & 1.52 & 0.020 & 0.064 & 0 \\
6 & 1939 & 0.22 & 2.19 & 1.30 & 0.004 & 0.066 & 0 \\
7 & 1940 & 0.41 & 2.60 & 0.89 & 0.012 & 0.065 & 0 \\
8 & 1941 & 0.43 & 3.04 & 0.45 & 0.038 & 0.062 & 0 \\
9 & 1942 & 0.40 & 3.44 & 0.05 & 0.100 & 0.054 & 0.4584 \\
10 & 1943 & 0.05 & 3.49 & 0 & -- & -- & --
\end{tabular}


Table E. 5 Flow U nit calculation with Predicted K for well 15-1110 into three zones.

\begin{tabular}{|c|c|c|c|c|c|c|c|}
\hline $\begin{array}{c}\text { Sample } \\
\text { No. per } \\
\text { G roup }\end{array}$ & $\begin{array}{l}\text { Depth, } \\
\text { Ft }\end{array}$ & $\begin{array}{l}\text { Predicted K, } \\
\text { mD }\end{array}$ & $\begin{array}{c}\text { Cum.Sum of } K \text {, } \\
\text { mD }\end{array}$ & $\begin{array}{c}\text { G rand Sum M inus } \\
\text { Cum. Sum, mD }\end{array}$ & $B, m^{2}$ & $\mathrm{~W}, \mathrm{mD}^{2}$ & $\begin{array}{l}\text { Zonation } \\
\text { Index, R }\end{array}$ \\
\hline \multicolumn{8}{|l|}{ Group1 } \\
\hline 1 & 1934 & 0.59 & 0.59 & 1.27 & 0.157 & 0.031 & 0.8024 \\
\hline 2 & 1935 & 0.73 & 1.33 & 0.53 & 0.162 & 0.030 & 0.8172 \\
\hline 3 & 1936 & 0.53 & 1.86 & 0 & -- & -- & -- \\
\hline \multicolumn{8}{|l|}{ Group2 } \\
\hline 1 & 1937 & 0.05 & 0.05 & 1.58 & 0.176 & 0.026 & 0.8535 \\
\hline 2 & 1938 & 0.06 & 0.11 & 1.52 & 0.200 & 0.019 & 0.9063 \\
\hline 3 & 1939 & 0.22 & 0.33 & 1.30 & 0.195 & 0.020 & 0.8967 \\
\hline 4 & 1940 & 0.41 & 0.74 & 0.89 & 0.167 & 0.028 & 0.8304 \\
\hline 5 & 1941 & 0.43 & 1.18 & 0.45 & 0.157 & 0.031 & 0.8006 \\
\hline 6 & 1942 & 0.40 & 1.58 & 0.05 & 0.176 & 0.026 & 0.8547 \\
\hline 7 & 1943 & 0.05 & 1.63 & 0 & -- & -- & -- \\
\hline
\end{tabular}

Table E . 6 Flow U nit calculation with Predicted K for well 15-1176 into two zones.

\begin{tabular}{|c|c|c|c|c|c|c|c|}
\hline $\begin{array}{l}\text { Sample } \\
\text { No. per } \\
\text { G roup }\end{array}$ & $\begin{array}{l}\text { Depth, } \\
\text { Ft }\end{array}$ & $\begin{array}{l}\text { Predicted K, } \\
\text { mD }\end{array}$ & $\begin{array}{c}\text { Cum.Sum of } K \text {, } \\
\text { mD }\end{array}$ & $\begin{array}{l}\text { Grand Sum M inus Cum. } \\
\qquad \text { Sum, mD }\end{array}$ & $B, m^{2}$ & $\mathrm{~W}, \mathrm{mD}^{2}$ & $\begin{array}{l}\text { Zonation } \\
\text { Index, R }\end{array}$ \\
\hline 1 & 2140 & 2.47 & 2.47 & 126.08 & 8.682 & 10.840 & 0 \\
\hline 2 & 2141 & 4.98 & 7.46 & 121.09 & 5.785 & 10.972 & 0 \\
\hline 3 & 2142 & 6.03 & 13.48 & 115.06 & 2.547 & 11.119 & 0 \\
\hline 4 & 2143 & 6.98 & 20.46 & 108.09 & 0.281 & 11.222 & 0 \\
\hline 5 & 2144 & 8.43 & 28.89 & 99.66 & 1.126 & 11.184 & 0 \\
\hline 6 & 2145 & 11.30 & 40.19 & 88.36 & 14.408 & 10.580 & 0.2657 \\
\hline 7 & 2146 & 9.34 & 49.53 & 79.02 & 29.230 & 9.906 & 0.6611 \\
\hline 8 & 2147 & 7.84 & 57.37 & 71.18 & 39.545 & 9.437 & 0.7614 \\
\hline 9 & 2148 & 6.30 & 63.67 & 64.88 & 42.509 & 9.303 & 0.7812 \\
\hline 10 & 2149 & 7.29 & 70.96 & 57.59 & 51.871 & 8.877 & 0.8289 \\
\hline 11 & 2150 & 8.43 & 79.39 & 49.16 & 70.346 & 8.037 & 0.8857 \\
\hline 12 & 2151 & 8.07 & 87.46 & 41.08 & 89.624 & 7.161 & 0.9201 \\
\hline 13 & 2152 & 7.84 & 95.30 & 33.24 & 110.621 & 6.207 & 0.9439 \\
\hline 14 & 2153 & 7.84 & 103.14 & 25.40 & 135.913 & 5.057 & 0.9628 \\
\hline 15 & 2154 & 6.48 & 109.63 & 18.92 & 152.460 & 4.305 & 0.9718 \\
\hline 16 & 2155 & 6.03 & 115.65 & 12.89 & 168.247 & 3.587 & 0.9787 \\
\hline 17 & 2156 & 5.21 & 120.86 & 7.69 & 179.180 & 3.090 & 0.9828 \\
\hline$* *$ & $* *$ & $* *$ & $* *$ & $* *$ & $* *$ & $* *$ & $* *$ \\
\hline 18 & 2157 & 3.22 & 124.08 & 4.47 & 170.086 & 3.504 & 0.9794 \\
\hline 19 & 2158 & 1.59 & 125.67 & 2.88 & 144.352 & 4.673 & 0.9676 \\
\hline 20 & 2159 & 0.77 & 126.44 & 2.11 & 111.928 & 6.147 & 0.9451 \\
\hline 21 & 2160 & 0.47 & 126.91 & 1.63 & 79.363 & 7.627 & 0.9039 \\
\hline 22 & 2161 & 0.59 & 127.50 & 1.04 & 50.980 & 8.918 & 0.8251 \\
\hline 23 & 2162 & 0.83 & 128.33 & 0.22 & 27.543 & 9.983 & 0.6375 \\
\hline 24 & 2163 & 0.22 & 128.55 & 0 & -- & -- & -- \\
\hline
\end{tabular}


Table E. 7 Flow Unit calculation with Predicted K for well 15-1176 into three zones.

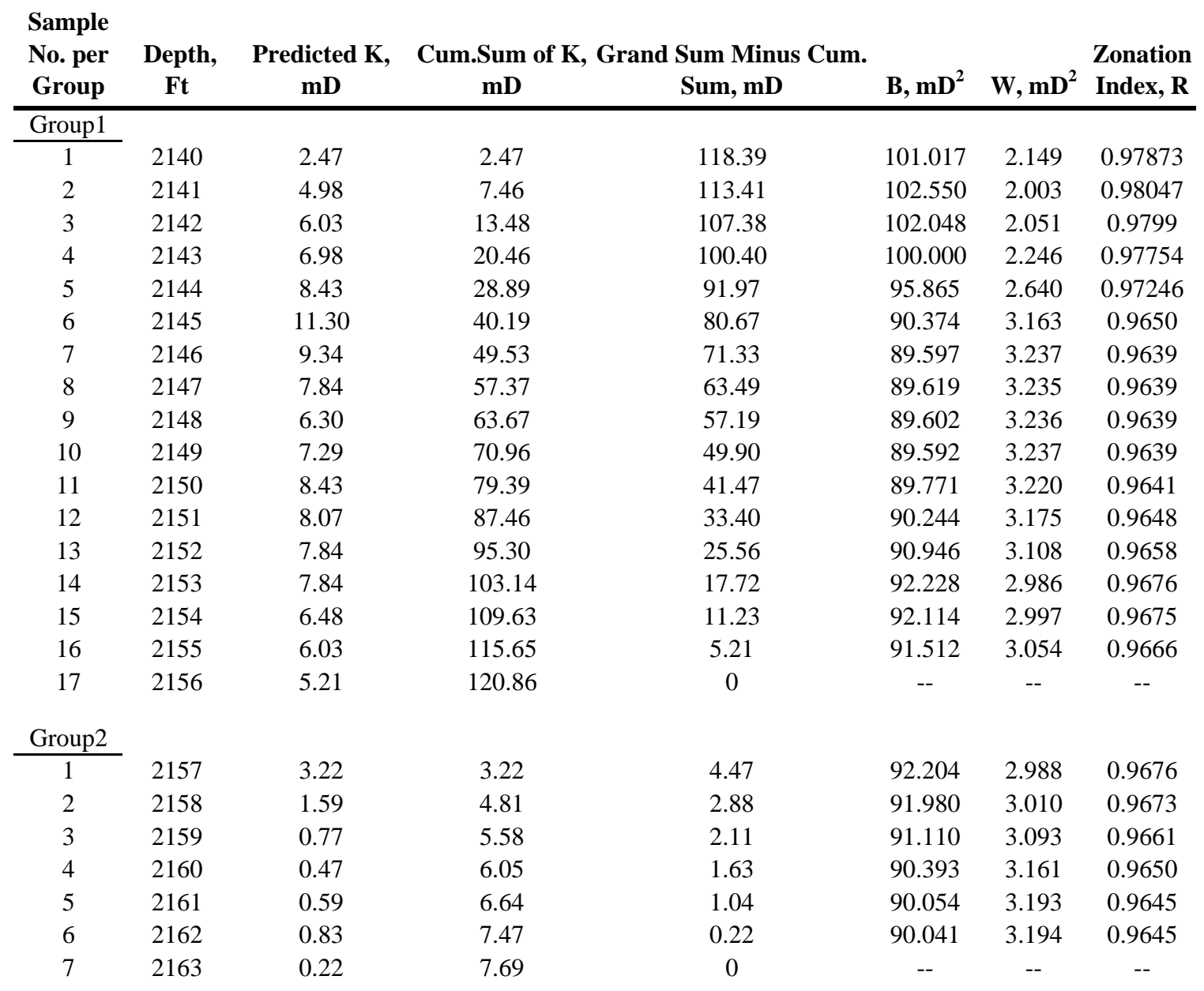


Table E. 8 Flow Unit calculation with Predicted K for well 15-1225 into two zones.

\begin{tabular}{|c|c|c|c|c|c|c|c|}
\hline $\begin{array}{l}\text { Sample } \\
\text { No. per } \\
\text { G roup }\end{array}$ & $\begin{array}{l}\text { Depth, } \\
\text { Ft }\end{array}$ & $\begin{array}{l}\text { Predicted K, } \\
\text { mD }\end{array}$ & $\underset{\mathrm{mD}}{\text { Cum.Sum of } K,}$ & $\begin{array}{c}\text { Grand Sum M inus } \\
\text { Cum. Sum, mD }\end{array}$ & $B, m D^{2}$ & $\mathrm{~W}, \mathrm{mD}^{2}$ & $\begin{array}{l}\text { Zonation } \\
\text { Index, R }\end{array}$ \\
\hline 1 & 2081 & 0.56 & 0.56 & 89.15 & 10.507 & 7.356 & 0.2999 \\
\hline 2 & 2082 & 0.53 & 1.09 & 88.63 & 22.246 & 6.823 & 0.6933 \\
\hline 3 & 2083 & 0.45 & 1.54 & 88.17 & 35.627 & 6.215 & 0.8256 \\
\hline 4 & 2084 & 0.77 & 2.31 & 87.40 & 47.938 & 5.655 & 0.8820 \\
\hline 5 & 2085 & 1.93 & 4.24 & 85.48 & 52.758 & 5.436 & 0.8970 \\
\hline$* *$ & $* *$ & $* *$ & $* *$ & $* *$ & $* *$ & $* *$ & $* *$ \\
\hline 6 & 2086 & 4.31 & 8.55 & 81.17 & 42.829 & 5.887 & 0.8625 \\
\hline 7 & 2087 & 6.12 & 14.66 & 75.05 & 26.697 & 6.620 & 0.7520 \\
\hline 8 & 2088 & 5.21 & 19.87 & 69.85 & 18.886 & 6.976 & 0.6306 \\
\hline 9 & 2089 & 5.36 & 25.23 & 64.48 & 12.581 & 7.262 & 0.4228 \\
\hline 10 & 2090 & 5.36 & 30.59 & 59.12 & 7.900 & 7.475 & 0.0539 \\
\hline 11 & 2091 & 6.30 & 36.89 & 52.83 & 3.003 & 7.697 & 0.0000 \\
\hline 12 & 2092 & 5.94 & 42.83 & 46.89 & 0.686 & 7.803 & 0.0000 \\
\hline 13 & 2093 & 7.61 & 50.44 & 39.27 & 0.573 & 7.808 & 0.0000 \\
\hline 14 & 2094 & 9.07 & 59.52 & 30.20 & 8.844 & 7.432 & 0.1597 \\
\hline 15 & 2095 & 7.50 & 67.02 & 22.70 & 21.310 & 6.865 & 0.6778 \\
\hline 16 & 2096 & 5.85 & 72.87 & 16.84 & 31.998 & 6.380 & 0.8006 \\
\hline 17 & 2097 & 4.84 & 77.71 & 12.00 & 40.471 & 5.994 & 0.8519 \\
\hline 18 & 2098 & 3.61 & 81.33 & 8.39 & 43.815 & 5.842 & 0.8667 \\
\hline 19 & 2099 & 3.12 & 84.45 & 5.26 & 45.539 & 5.764 & 0.8734 \\
\hline 20 & 2100 & 2.47 & 86.92 & 2.79 & 44.355 & 5.818 & 0.8688 \\
\hline 21 & 2101 & 1.85 & 88.77 & 0.95 & 40.153 & 6.009 & 0.8503 \\
\hline 22 & 2102 & 0.66 & 89.43 & 0.28 & 28.212 & 6.552 & 0.7678 \\
\hline 23 & 2103 & 0.23 & 89.66 & 0.06 & 14.121 & 7.192 & 0.4907 \\
\hline 24 & 2104 & 0.06 & 89.72 & 0 & -- & -- & -- \\
\hline
\end{tabular}


Table E. 9 Flow U nit calculation with Predicted K for well 15-1225 into three zones.

\begin{tabular}{|c|c|c|c|c|c|c|c|}
\hline $\begin{array}{c}\text { Sample } \\
\text { No. per } \\
\text { G roup }\end{array}$ & $\begin{array}{l}\text { Depth, } \\
\text { Ft }\end{array}$ & $\begin{array}{l}\text { Predicted K, } \\
\text { mD }\end{array}$ & $\begin{array}{c}\text { Cum.Sum of } K, \\
\mathrm{mD}\end{array}$ & $\begin{array}{l}\text { G rand Sum M inus } \\
\text { C um. Sum, mD }\end{array}$ & $B, m D^{2}$ & $\mathrm{~W}, \mathrm{mD}^{2}$ & $\begin{array}{l}\text { Zonation } \\
\text { Index, R }\end{array}$ \\
\hline \multicolumn{8}{|l|}{ Group1 } \\
\hline 1 & 2081 & 0.56 & 0.56 & 3.67 & 26.429 & 5.690 & 0.7847 \\
\hline 2 & 2082 & 0.53 & 1.09 & 3.15 & 26.532 & 5.680 & 0.7859 \\
\hline 3 & 2083 & 0.45 & 1.54 & 2.70 & 26.796 & 5.655 & 0.7890 \\
\hline 4 & 2084 & 0.77 & 2.31 & 1.93 & 27.108 & 5.625 & 0.7925 \\
\hline 5 & 2085 & 1.93 & 4.24 & 0 & -- & -- & -- \\
\hline \multicolumn{8}{|l|}{ Group2 } \\
\hline 1 & 2086 & 4.31 & 4.31 & 81.17 & 26.399 & 5.693 & 0.7844 \\
\hline 2 & 2087 & 6.12 & 10.42 & 75.05 & 26.946 & 5.641 & 0.7907 \\
\hline 3 & 2088 & 5.21 & 15.63 & 69.85 & 27.280 & 5.609 & 0.7944 \\
\hline 4 & 2089 & 5.36 & 20.99 & 64.48 & 27.801 & 5.559 & 0.8000 \\
\hline 5 & 2090 & 5.36 & 26.35 & 59.12 & 28.401 & 5.502 & 0.8063 \\
\hline 6 & 2091 & 6.30 & 32.65 & 52.83 & 30.278 & 5.323 & 0.8242 \\
\hline 7 & 2092 & 5.94 & 38.59 & 46.89 & 32.078 & 5.152 & 0.8394 \\
\hline 8 & 2093 & 7.61 & 46.20 & 39.27 & 37.641 & 4.622 & 0.8772 \\
\hline 9 & 2094 & 9.07 & 55.28 & 30.20 & 49.465 & 3.496 & 0.9293 \\
\hline 10 & 2095 & 7.50 & 62.78 & 22.70 & 59.800 & 2.512 & 0.9580 \\
\hline 11 & 2096 & 5.85 & 68.63 & 16.84 & 65.961 & 1.925 & 0.9708 \\
\hline 12 & 2097 & 4.84 & 73.47 & 12.00 & 69.339 & 1.603 & 0.9769 \\
\hline$* *$ & $* *$ & $* *$ & $* *$ & $* *$ & $* *$ & $* *$ & $* *$ \\
\hline 13 & 2098 & 3.61 & 77.09 & 8.39 & 68.538 & 1.680 & 0.9755 \\
\hline 14 & 2099 & 3.12 & 80.21 & 5.26 & 66.664 & 1.858 & 0.9721 \\
\hline 15 & 2100 & 2.47 & 82.68 & 2.79 & 62.969 & 2.210 & 0.9649 \\
\hline 16 & 2101 & 1.85 & 84.53 & 0.95 & 57.543 & 2.727 & 0.9526 \\
\hline 17 & 2102 & 0.66 & 85.19 & 0.28 & 47.591 & 3.675 & 0.9228 \\
\hline 18 & 2103 & 0.23 & 85.42 & 0.06 & 36.780 & 4.704 & 0.8721 \\
\hline 19 & 2104 & 0.06 & 85.48 & 0 & -- & -- & -- \\
\hline
\end{tabular}


Table E. 10 Flow U nit calculation with Predicted K for well 15-1243 into two zones.

\begin{tabular}{|c|c|c|c|c|c|c|c|}
\hline $\begin{array}{c}\text { Sample } \\
\text { No. per } \\
\text { G roup }\end{array}$ & $\begin{array}{l}\text { Depth, } \\
\text { Ft }\end{array}$ & $\begin{array}{l}\text { Predicted K, } \\
\text { mD }\end{array}$ & $\begin{array}{c}\text { Cum.Sum of } K \text {, } \\
\text { mD }\end{array}$ & $\begin{array}{l}\text { G rand Sum M inus C um. } \\
\text { Sum, mD }\end{array}$ & $B, m^{2}$ & $\mathrm{~W}, \mathrm{mD}^{2}$ & $\begin{array}{l}\text { Zonation } \\
\text { Index, R }\end{array}$ \\
\hline 1 & 1988 & 0.42 & 0.42 & 113.30 & 21.385 & 7.781 & 0.6362 \\
\hline 2 & 1989 & 0.66 & 1.09 & 112.64 & 42.445 & 6.778 & 0.8403 \\
\hline 3 & 1990 & 1.09 & 2.18 & 111.55 & 61.420 & 5.874 & 0.9044 \\
\hline 4 & 1991 & 2.30 & 4.47 & 109.25 & 70.890 & 5.423 & 0.9235 \\
\hline$* *$ & $* *$ & $* *$ & $* *$ & $* *$ & $* *$ & $* *$ & $* *$ \\
\hline 5 & 1992 & 4.77 & 9.24 & 104.48 & 61.234 & 5.883 & 0.9039 \\
\hline 6 & 1993 & 7.08 & 16.32 & 97.40 & 40.164 & 6.887 & 0.8285 \\
\hline 7 & 1994 & 7.84 & 24.16 & 89.56 & 22.429 & 7.731 & 0.6553 \\
\hline 8 & 1995 & 8.94 & 33.10 & 80.62 & 7.982 & 8.419 & 0 \\
\hline 9 & 1996 & 8.94 & 42.05 & 71.68 & 1.101 & 8.747 & 0 \\
\hline 10 & 1997 & 8.19 & 50.24 & 63.49 & 0.111 & 8.794 & 0 \\
\hline 11 & 1998 & 8.19 & 58.43 & 55.30 & 2.841 & 8.664 & 0 \\
\hline 12 & 1999 & 7.18 & 65.61 & 48.12 & 6.861 & 8.472 & 0 \\
\hline 13 & 2000 & 6.77 & 72.38 & 41.34 & 11.621 & 8.246 & 0.2905 \\
\hline 14 & 2001 & 6.03 & 78.41 & 35.31 & 15.406 & 8.065 & 0.4765 \\
\hline 15 & 2002 & 5.21 & 83.62 & 30.11 & 17.116 & 7.984 & 0.5335 \\
\hline 16 & 2003 & 5.21 & 88.83 & 24.90 & 19.373 & 7.877 & 0.5934 \\
\hline 17 & 2004 & 5.60 & 94.43 & 19.30 & 24.250 & 7.644 & 0.6848 \\
\hline 18 & 2005 & 6.48 & 100.91 & 12.81 & 36.246 & 7.073 & 0.8049 \\
\hline 19 & 2006 & 5.60 & 106.51 & 7.21 & 47.794 & 6.523 & 0.8635 \\
\hline 20 & 2007 & 3.36 & 109.87 & 3.85 & 46.229 & 6.598 & 0.8573 \\
\hline 21 & 2008 & 2.54 & 112.42 & 1.31 & 40.333 & 6.879 & 0.8295 \\
\hline 22 & 2009 & 0.92 & 113.33 & 0.39 & 21.667 & 7.767 & 0.6415 \\
\hline 23 & 2010 & 0.39 & 113.72 & 0 & -- & -- & -- \\
\hline
\end{tabular}


Table E. 11 Flow Unit calculation with Predicted K for well 15-1243 into three zones.

\begin{tabular}{|c|c|c|c|c|c|c|c|}
\hline $\begin{array}{l}\text { Sample } \\
\text { No. per } \\
\text { G roup }\end{array}$ & $\begin{array}{l}\text { Depth, } \\
\text { Ft }\end{array}$ & $\begin{array}{l}\text { Predicted K, } \\
\text { mD }\end{array}$ & $\begin{array}{c}\text { Cum.Sum of } K, \\
\mathrm{mD}\end{array}$ & $\begin{array}{l}\text { G rand Sum M inus C um. } \\
\text { Sum, mD }\end{array}$ & $B, m^{2}$ & $\mathrm{~W}, \mathrm{mD}^{2}$ & $\begin{array}{l}\text { Zonation } \\
\text { Index, R }\end{array}$ \\
\hline \multicolumn{8}{|l|}{ Group1 } \\
\hline 1 & 1988 & 0.42 & 0.42 & 4.05 & 35.769 & 5.662 & 0.8417 \\
\hline 2 & 1989 & 0.66 & 1.09 & 3.39 & 36.108 & 5.628 & 0.8441 \\
\hline 3 & 1990 & 1.09 & 2.18 & 2.30 & 36.372 & 5.602 & 0.8460 \\
\hline 4 & 1991 & 2.30 & 4.47 & 0 & -- & -- & -- \\
\hline \multicolumn{8}{|l|}{ Group2 } \\
\hline 1 & 1992 & 4.77 & 4.77 & 104.48 & 35.952 & 5.644 & 0.8430 \\
\hline 2 & 1993 & 7.08 & 11.85 & 97.40 & 35.479 & 5.691 & 0.8396 \\
\hline 3 & 1994 & 7.84 & 19.69 & 89.56 & 36.621 & 5.577 & 0.8477 \\
\hline 4 & 1995 & 8.94 & 28.63 & 80.62 & 40.463 & 5.193 & 0.8717 \\
\hline 5 & 1996 & 8.94 & 37.57 & 71.68 & 46.006 & 4.638 & 0.8992 \\
\hline 6 & 1997 & 8.19 & 45.76 & 63.49 & 50.895 & 4.150 & 0.9185 \\
\hline 7 & 1998 & 8.19 & 53.95 & 55.30 & 56.685 & 3.571 & 0.9370 \\
\hline 8 & 1999 & 7.18 & 61.14 & 48.12 & 60.177 & 3.221 & 0.9465 \\
\hline 9 & 2000 & 6.77 & 67.91 & 41.34 & 63.010 & 2.938 & 0.9534 \\
\hline 10 & 2001 & 6.03 & 73.94 & 35.31 & 63.963 & 2.843 & 0.9556 \\
\hline 11 & 2002 & 5.21 & 79.15 & 30.11 & 62.717 & 2.967 & 0.9527 \\
\hline 12 & 2003 & 5.21 & 84.35 & 24.90 & 62.098 & 3.029 & 0.9512 \\
\hline 13 & 2004 & 5.60 & 89.95 & 19.30 & 63.598 & 2.879 & 0.9547 \\
\hline 14 & 2005 & 6.48 & 96.44 & 12.81 & 69.915 & 2.248 & 0.9679 \\
\hline 15 & 2006 & 5.60 & 102.04 & 7.21 & 74.917 & 1.747 & 0.9767 \\
\hline$* *$ & $* *$ & $* *$ & $* *$ & $* *$ & $* *$ & $* *$ & $* *$ \\
\hline 16 & 2007 & 3.36 & 105.40 & 3.85 & 70.974 & 2.142 & 0.9698 \\
\hline 17 & 2008 & 2.54 & 107.94 & 1.31 & 64.476 & 2.791 & 0.9567 \\
\hline 18 & 2009 & 0.92 & 108.86 & 0.39 & 50.597 & 4.179 & 0.9174 \\
\hline 19 & 2010 & 0.39 & 109.25 & 0 & -- & -- & -- \\
\hline
\end{tabular}


Table E. 12 Flow U nit calculation with Predicted K for well 15-1621 into two zones.

\begin{tabular}{|c|c|c|c|c|c|c|c|}
\hline $\begin{array}{l}\text { Sample } \\
\text { No. per } \\
\text { Group }\end{array}$ & $\begin{array}{l}\text { Depth, } \\
\text { Ft }\end{array}$ & $\begin{array}{l}\text { Predicted K, } \\
\text { mD }\end{array}$ & $\begin{array}{c}\text { Cum.Sum of } K, \\
\mathrm{mD}\end{array}$ & $\begin{array}{l}\text { Grand Sum M inus } \\
\text { Cum. Sum, mD }\end{array}$ & $B, m D^{2}$ & $\mathrm{~W}, \mathrm{mD}^{2}$ & $\begin{array}{l}\text { Zonation } \\
\text { Index, R }\end{array}$ \\
\hline 1 & 2080 & 2.70 & 2.70 & 43.60 & 0.491 & 1.539 & 0 \\
\hline 2 & 2081 & 2.58 & 5.28 & 41.02 & 0.862 & 1.521 & 0 \\
\hline 3 & 2082 & 2.51 & 7.79 & 38.51 & 1.173 & 1.506 & 0 \\
\hline 4 & 2083 & 2.10 & 9.89 & 36.40 & 1.026 & 1.513 & 0 \\
\hline 5 & 2084 & 1.67 & 11.56 & 34.74 & 0.571 & 1.535 & 0 \\
\hline 6 & 2085 & 0.94 & 12.50 & 33.80 & 0.040 & 1.560 & 0 \\
\hline 7 & 2086 & 1.09 & 13.59 & 32.71 & 0.051 & 1.560 & 0 \\
\hline 8 & 2087 & 1.34 & 14.93 & 31.37 & 0.264 & 1.550 & 0 \\
\hline 9 & 2088 & 1.19 & 16.12 & 30.18 & 0.728 & 1.528 & 0 \\
\hline 10 & 2089 & 1.93 & 18.05 & 28.25 & 0.767 & 1.526 & 0 \\
\hline 11 & 2090 & 4.18 & 22.23 & 24.07 & 0.001 & 1.562 & 0 \\
\hline 12 & 2091 & 4.24 & 26.47 & 19.82 & 0.937 & 1.518 & 0 \\
\hline 13 & 2092 & 4.12 & 30.60 & 15.70 & 3.469 & 1.397 & 0.5973 \\
\hline 14 & 2093 & 2.90 & 33.50 & 12.80 & 5.162 & 1.316 & 0.7450 \\
\hline 15 & 2094 & 2.74 & 36.24 & 10.06 & 6.998 & 1.229 & 0.8244 \\
\hline 16 & 2095 & 3.17 & 39.40 & 6.89 & 10.640 & 1.056 & 0.9008 \\
\hline 17 & 2096 & 2.62 & 42.03 & 4.27 & 13.738 & 0.908 & 0.9339 \\
\hline$* *$ & $* *$ & $* *$ & $* *$ & $* *$ & $* *$ & $* *$ & $* *$ \\
\hline 18 & 2097 & 1.48 & 43.51 & 2.79 & 13.524 & 0.918 & 0.9321 \\
\hline 19 & 2098 & 1.06 & 44.57 & 1.73 & 12.090 & 0.986 & 0.9184 \\
\hline 20 & 2099 & 0.68 & 45.25 & 1.05 & 9.549 & 1.108 & 0.8840 \\
\hline 21 & 2100 & 0.56 & 45.81 & 0.48 & 6.874 & 1.235 & 0.8204 \\
\hline 22 & 2101 & 0.33 & 46.14 & 0.15 & 3.613 & 1.390 & 0.6152 \\
\hline 23 & 2102 & 0.15 & 46.30 & 0 & -- & -- & -- \\
\hline
\end{tabular}


Table E. 13 Flow Unit calculation with Predicted K for well 15-1621 into three zones.

\begin{tabular}{|c|c|c|c|c|c|c|c|}
\hline $\begin{array}{l}\text { Sample } \\
\text { No. per } \\
\text { G roup }\end{array}$ & $\begin{array}{l}\text { Depth, } \\
\text { Ft }\end{array}$ & $\begin{array}{l}\text { Predicted K, } \\
\text { mD }\end{array}$ & $\begin{array}{c}\text { Cum.Sum of } K, \\
\text { mD }\end{array}$ & $\begin{array}{l}\text { Grand Sum M inus } \\
\text { Cum. Sum, mD }\end{array}$ & $B, \mathrm{mD}^{2}$ & $\mathrm{~W}, \mathrm{mD}^{2}$ & $\begin{array}{l}\text { Zonation } \\
\text { Index, R }\end{array}$ \\
\hline \multicolumn{8}{|l|}{ Group1 } \\
\hline 1 & 2080 & 2.70 & 2.70 & 39.33 & 6.896 & 0.951 & 0.86214 \\
\hline 2 & 2081 & 2.58 & 5.28 & 36.74 & 6.901 & 0.950 & 0.86231 \\
\hline 3 & 2082 & 2.51 & 7.79 & 34.24 & 6.897 & 0.951 & 0.86217 \\
\hline 4 & 2083 & 2.10 & 9.89 & 32.13 & 6.869 & 0.953 & 0.8612 \\
\hline 5 & 2084 & 1.67 & 11.56 & 30.47 & 6.960 & 0.944 & 0.86432 \\
\hline 6 & 2085 & 0.94 & 12.50 & 29.52 & 7.569 & 0.883 & 0.88329 \\
\hline 7 & 2086 & 1.09 & 13.59 & 28.43 & 8.543 & 0.786 & 0.908 \\
\hline 8 & 2087 & 1.34 & 14.93 & 27.10 & 9.643 & 0.676 & 0.92989 \\
\hline 9 & 2088 & 1.19 & 16.12 & 25.91 & 11.304 & 0.510 & 0.95489 \\
\hline 10 & 2089 & 1.93 & 18.05 & 23.98 & 12.276 & 0.413 & 0.96638 \\
\hline$* *$ & $* *$ & $* *$ & $* *$ & $* *$ & $* *$ & $* *$ & $* *$ \\
\hline 11 & 2090 & 4.18 & 22.23 & 19.80 & 10.041 & 0.636 & 0.93664 \\
\hline 12 & 2091 & 4.24 & 26.47 & 15.55 & 8.311 & 0.809 & 0.90264 \\
\hline 13 & 2092 & 4.12 & 30.60 & 11.43 & 7.257 & 0.915 & 0.8740 \\
\hline 14 & 2093 & 2.90 & 33.50 & 8.53 & 7.119 & 0.928 & 0.8696 \\
\hline 15 & 2094 & 2.74 & 36.24 & 5.79 & 7.071 & 0.933 & 0.8680 \\
\hline 16 & 2095 & 3.17 & 39.40 & 2.62 & 6.881 & 0.952 & 0.8616 \\
\hline 17 & 2096 & 2.62 & 42.03 & 0 & -- & -- & -- \\
\hline \multicolumn{8}{|l|}{ Group2 } \\
\hline 1 & 2097 & 1.48 & 1.48 & 2.79 & 7.225 & 0.918 & 0.8730 \\
\hline 2 & 2098 & 1.06 & 2.54 & 1.73 & 7.337 & 0.907 & 0.8764 \\
\hline 3 & 2099 & 0.68 & 3.22 & 1.05 & 7.264 & 0.914 & 0.8742 \\
\hline 4 & 2100 & 0.56 & 3.79 & 0.48 & 7.201 & 0.920 & 0.8722 \\
\hline 5 & 2101 & 0.33 & 4.12 & 0.15 & 7.056 & 0.935 & 0.8675 \\
\hline 6 & 2102 & 0.15 & 4.27 & 0 & -- & -- & -- \\
\hline
\end{tabular}


Table E. 14 Flow U nit calculation with Predicted K for well 15-1639 into two zones.

\begin{tabular}{|c|c|c|c|c|c|c|c|}
\hline $\begin{array}{l}\text { Sample } \\
\text { No. per } \\
\text { G roup }\end{array}$ & $\begin{array}{l}\text { Depth, } \\
\text { Ft }\end{array}$ & $\begin{array}{l}\text { Predicted K, } \\
\text { mD }\end{array}$ & $\underset{\mathrm{mD}}{\text { Cum.Sum of } K,}$ & $\begin{array}{l}\text { Grand Sum M inus } \\
\text { C um. Sum, mD }\end{array}$ & $B, m D^{2}$ & $W, m D^{2}$ & $\begin{array}{l}\text { Zonation } \\
\text { Index, R }\end{array}$ \\
\hline 1 & 1977 & 0.58 & 0.58 & 61.15 & 3.017 & 1.269 & 0.5795 \\
\hline 2 & 1978 & 0.73 & 1.32 & 60.41 & 5.725 & 1.161 & 0.7973 \\
\hline 3 & 1979 & 1.26 & 2.58 & 59.15 & 6.870 & 1.115 & 0.8377 \\
\hline 4 & 1980 & 1.40 & 3.98 & 57.75 & 7.840 & 1.076 & 0.8628 \\
\hline 5 & 1981 & 1.72 & 5.69 & 56.04 & 8.086 & 1.066 & 0.8682 \\
\hline 6 & 1982 & 1.67 & 7.36 & 54.37 & 8.668 & 1.043 & 0.8797 \\
\hline 7 & 1983 & 1.93 & 9.29 & 52.44 & 8.705 & 1.041 & 0.8804 \\
\hline 8 & 1984 & 2.90 & 12.19 & 49.54 & 6.615 & 1.125 & 0.8299 \\
\hline 9 & 1985 & 3.08 & 15.27 & 46.46 & 4.702 & 1.201 & 0.7445 \\
\hline 10 & 1986 & 3.17 & 18.43 & 43.30 & 3.116 & 1.265 & 0.5940 \\
\hline 11 & 1987 & 3.03 & 21.47 & 40.26 & 2.081 & 1.306 & 0.3721 \\
\hline 12 & 1988 & 3.03 & 24.50 & 37.23 & 1.293 & 1.338 & 0 \\
\hline 13 & 1989 & 3.03 & 27.53 & 34.20 & 0.711 & 1.361 & 0 \\
\hline 14 & 1990 & 3.67 & 31.20 & 30.53 & 0.097 & 1.386 & 0 \\
\hline 15 & 1991 & 3.41 & 34.61 & 27.12 & 0.015 & 1.389 & 0 \\
\hline 16 & 1992 & 3.46 & 38.07 & 23.66 & 0.339 & 1.376 & 0 \\
\hline 17 & 1993 & 4.43 & 42.50 & 19.23 & 2.097 & 1.306 & 0.3774 \\
\hline 18 & 1994 & 3.78 & 46.28 & 15.45 & 4.375 & 1.215 & 0.7224 \\
\hline 19 & 1995 & 3.41 & 49.69 & 12.04 & 6.929 & 1.112 & 0.8395 \\
\hline 20 & 1996 & 2.90 & 52.59 & 9.14 & 9.081 & 1.026 & 0.8870 \\
\hline 21 & 1997 & 2.40 & 54.99 & 6.74 & 10.428 & 0.972 & 0.9068 \\
\hline 22 & 1998 & 2.07 & 57.06 & 4.67 & 11.229 & 0.940 & 0.9163 \\
\hline$* *$ & $* *$ & $* *$ & $* *$ & $* *$ & $* *$ & $* *$ & $* *$ \\
\hline 23 & 1999 & 1.62 & 58.68 & 3.05 & 10.904 & 0.953 & 0.9126 \\
\hline 24 & 2000 & 1.26 & 59.94 & 1.79 & 9.644 & 1.004 & 0.8959 \\
\hline 25 & 2001 & 0.83 & 60.77 & 0.96 & 7.041 & 1.108 & 0.8426 \\
\hline 26 & 2002 & 0.67 & 61.44 & 0.29 & 4.145 & 1.224 & 0.7048 \\
\hline 27 & 2003 & 0.29 & 61.73 & 0 & -- & -- & -- \\
\hline
\end{tabular}


Table E. 15 Flow Unit calculation with Predicted K for well 15-1639 into three zones.

\begin{tabular}{|c|c|c|c|c|c|c|c|}
\hline $\begin{array}{c}\text { Sample } \\
\text { No. per } \\
\text { G roup }\end{array}$ & $\begin{array}{l}\text { Depth, } \\
\text { Ft }\end{array}$ & $\begin{array}{l}\text { Predicted K, } \\
\text { mD }\end{array}$ & $\begin{array}{c}\text { Cum.Sum of } K, \\
\text { mD }\end{array}$ & $\begin{array}{l}\text { Grand Sum M inus } \\
\text { C um. Sum, mD }\end{array}$ & $B, m^{2}$ & $\mathrm{~W}, \mathrm{mD}^{2}$ & $\begin{array}{l}\text { Zonation } \\
\text { Index, R }\end{array}$ \\
\hline \multicolumn{8}{|l|}{ Group1 } \\
\hline 1 & 1977 & 0.58 & 0.58 & 56.48 & 7.735 & 0.803 & 0.8962 \\
\hline 2 & 1978 & 0.73 & 1.32 & 55.75 & 9.735 & 0.636 & 0.9347 \\
\hline 3 & 1979 & 1.26 & 2.58 & 54.48 & 10.838 & 0.544 & 0.9498 \\
\hline 4 & 1980 & 1.40 & 3.98 & 53.09 & 11.869 & 0.458 & 0.9614 \\
\hline 5 & 1981 & 1.72 & 5.69 & 51.37 & 12.468 & 0.408 & 0.9672 \\
\hline 6 & 1982 & 1.67 & 7.36 & 49.70 & 13.328 & 0.337 & 0.9747 \\
\hline 7 & 1983 & 1.93 & 9.29 & 47.78 & 13.858 & 0.293 & 0.9789 \\
\hline$* *$ & $* *$ & $* *$ & $* *$ & $* *$ & $* *$ & $* *$ & $* *$ \\
\hline 8 & 1984 & 2.90 & 12.19 & 44.87 & 12.814 & 0.380 & 0.9704 \\
\hline 9 & 1985 & 3.08 & 15.27 & 41.80 & 11.750 & 0.468 & 0.9602 \\
\hline 10 & 1986 & 3.17 & 18.43 & 38.63 & 10.776 & 0.549 & 0.9490 \\
\hline 11 & 1987 & 3.03 & 21.47 & 35.60 & 10.152 & 0.601 & 0.9408 \\
\hline 12 & 1988 & 3.03 & 24.50 & 32.56 & 9.639 & 0.644 & 0.93317 \\
\hline 13 & 1989 & 3.03 & 27.53 & 29.53 & 9.213 & 0.680 & 0.92623 \\
\hline 14 & 1990 & 3.67 & 31.20 & 25.86 & 8.183 & 0.766 & 0.90645 \\
\hline 15 & 1991 & 3.41 & 34.61 & 22.45 & 7.550 & 0.818 & 0.89163 \\
\hline 16 & 1992 & 3.46 & 38.07 & 19.00 & 6.965 & 0.867 & 0.87553 \\
\hline 17 & 1993 & 4.43 & 42.50 & 14.56 & 5.943 & 0.952 & 0.8398 \\
\hline 18 & 1994 & 3.78 & 46.28 & 10.79 & 5.641 & 0.977 & 0.8267 \\
\hline 19 & 1995 & 3.41 & 49.69 & 7.38 & 5.646 & 0.977 & 0.8270 \\
\hline 20 & 1996 & 2.90 & 52.59 & 4.47 & 5.755 & 0.968 & 0.8318 \\
\hline 21 & 1997 & 2.40 & 54.99 & 2.07 & 5.756 & 0.968 & 0.8319 \\
\hline 22 & 1998 & 2.07 & 57.06 & 0 & -- & -- & -- \\
\hline \multicolumn{8}{|l|}{ Group2 } \\
\hline 1 & 1999 & 1.62 & 1.62 & 3.05 & 5.907 & 0.955 & 0.8383 \\
\hline 2 & 2000 & 1.26 & 2.88 & 1.79 & 6.042 & 0.944 & 0.8438 \\
\hline 3 & 2001 & 0.83 & 3.71 & 0.96 & 5.956 & 0.951 & 0.8403 \\
\hline 4 & 2002 & 0.67 & 4.38 & 0.29 & 5.875 & 0.958 & 0.8370 \\
\hline 5 & 2003 & 0.29 & 4.67 & 0 & -- & -- & -- \\
\hline
\end{tabular}


Table E. 16 Flow U nit calculation with Predicted K for well 15-1649 into two zones.

\begin{tabular}{|c|c|c|c|c|c|c|c|}
\hline $\begin{array}{l}\text { No. per } \\
\text { G roup }\end{array}$ & $\begin{array}{l}\text { Depth, } \\
\text { Ft }\end{array}$ & $\begin{array}{l}\text { Predicted K, } \\
\text { mD }\end{array}$ & $\begin{array}{c}\text { Cum.Sum of } K \text {, } \\
\mathrm{mD}\end{array}$ & $\begin{array}{l}\text { G rand Sum M inus } \\
\text { Cum. Sum, mD }\end{array}$ & $B, m^{2}$ & $\mathrm{~W}, \mathrm{mD}^{2}$ & $\begin{array}{l}\text { Zonation } \\
\text { Index, R }\end{array}$ \\
\hline 1 & 2181 & 0.35 & 0.35 & 6.69 & 0.008 & 0.123 & 0 \\
\hline 2 & 2182 & 0.62 & 0.97 & 6.07 & 0.005 & 0.123 & 0 \\
\hline 3 & 2183 & 1.11 & 2.08 & 4.97 & 0.235 & 0.106 & 0.5462 \\
\hline 4 & 2184 & 1.06 & 3.14 & 3.91 & 0.630 & 0.078 & 0.8759 \\
\hline 5 & 2185 & 0.75 & 3.88 & 3.16 & 0.821 & 0.065 & 0.9214 \\
\hline 6 & 2186 & 0.61 & 4.49 & 2.56 & 0.910 & 0.058 & 0.9361 \\
\hline 7 & 2187 & 0.64 & 5.12 & 1.92 & 1.059 & 0.048 & 0.9551 \\
\hline 8 & 2188 & 0.60 & 5.72 & 1.32 & 1.211 & 0.037 & 0.9597 \\
\hline 9 & 2189 & 0.34 & 6.06 & 0.98 & 1.119 & 0.043 & 0.9614 \\
\hline$* *$ & $* *$ & $* *$ & $* *$ & $* *$ & $* *$ & $* *$ & $* *$ \\
\hline 10 & 2190 & 0.27 & 6.33 & 0.71 & 0.995 & 0.052 & 0.9475 \\
\hline 11 & 2191 & 0.12 & 6.46 & 0.59 & 0.757 & 0.069 & 0.9086 \\
\hline 12 & 2192 & 0.13 & 6.59 & 0.46 & 0.565 & 0.083 & 0.8532 \\
\hline 13 & 2193 & 0.20 & 6.79 & 0.26 & 0.465 & 0.090 & 0.8063 \\
\hline 14 & 2194 & 0.13 & 6.92 & 0.12 & 0.329 & 0.100 & 0.6971 \\
\hline 15 & 2195 & 0.08 & 7.01 & 0.04 & 0.172 & 0.111 & 0.3564 \\
\hline 16 & 2196 & 0.04 & 7.05 & 0 & -- & -- & -- \\
\hline
\end{tabular}

Table E. 17 Flow U nit calculation with Predicted K for well 15-1783 into two zones.

\begin{tabular}{|c|c|c|c|c|c|c|c|}
\hline $\begin{array}{l}\text { Sample } \\
\text { No. per } \\
\text { G roup }\end{array}$ & $\begin{array}{l}\text { Depth, } \\
\text { Ft }\end{array}$ & $\begin{array}{l}\text { Predicted K, } \\
\text { mD }\end{array}$ & $\begin{array}{c}\text { Cum.Sum of } K \text {, } \\
\text { mD }\end{array}$ & $\begin{array}{l}\text { G rand Sum M inus } \\
\text { Cum. Sum, mD }\end{array}$ & $B, m^{2}$ & $\mathrm{~W}, \mathrm{mD}^{2}$ & $\begin{array}{l}\text { Zonation } \\
\text { Index, R }\end{array}$ \\
\hline 1 & 1994 & 0.92 & 0.92 & 53.73 & 2.989 & 2.101 & 0.2973 \\
\hline 2 & 1995 & 1.30 & 2.21 & 52.44 & 4.941 & 1.998 & 0.5957 \\
\hline 3 & 1996 & 1.57 & 3.79 & 50.86 & 6.289 & 1.927 & 0.6936 \\
\hline 4 & 1997 & 2.17 & 5.95 & 48.70 & 6.134 & 1.935 & 0.6845 \\
\hline 5 & 1998 & 2.95 & 8.90 & 45.75 & 4.442 & 2.024 & 0.5444 \\
\hline 6 & 1999 & 4.18 & 13.08 & 41.57 & 1.498 & 2.179 & 0 \\
\hline 7 & 2000 & 4.18 & 17.26 & 37.39 & 0.195 & 2.248 & 0 \\
\hline 8 & 2001 & 3.83 & 21.09 & 33.56 & 0.015 & 2.257 & 0 \\
\hline 9 & 2002 & 4.18 & 25.28 & 29.37 & 0.670 & 2.223 & 0 \\
\hline 10 & 2003 & 3.61 & 28.89 & 25.76 & 1.569 & 2.175 & 0 \\
\hline 11 & 2004 & 3.17 & 32.06 & 22.59 & 2.250 & 2.139 & 0.0493 \\
\hline 12 & 2005 & 4.50 & 36.56 & 18.09 & 5.525 & 1.967 & 0.6440 \\
\hline 13 & 2006 & 5.28 & 41.84 & 12.81 & 12.963 & 1.576 & 0.8784 \\
\hline 14 & 2007 & 3.61 & 45.46 & 9.19 & 17.449 & 1.340 & 0.9232 \\
\hline 15 & 2008 & 2.70 & 48.15 & 6.49 & 19.405 & 1.237 & 0.9363 \\
\hline$* *$ & $* *$ & $* *$ & $* *$ & $* *$ & $* *$ & $* *$ & $* *$ \\
\hline 16 & 2009 & 1.44 & 49.59 & 5.06 & 16.618 & 1.383 & 0.9168 \\
\hline 17 & 2010 & 1.16 & 50.75 & 3.90 & 13.089 & 1.569 & 0.8801 \\
\hline 18 & 2011 & 0.88 & 51.63 & 3.02 & 8.899 & 1.790 & 0.7989 \\
\hline 19 & 2012 & 1.72 & 53.34 & 1.31 & 8.390 & 1.816 & 0.7835 \\
\hline 20 & 2013 & 0.73 & 54.08 & 0.57 & 4.323 & 2.030 & 0.5303 \\
\hline 21 & 2014 & 0.57 & 54.65 & 0 & -- & -- & -- \\
\hline
\end{tabular}


Table E. 18 Flow Unit calculation with Predicted K for well 15-1783 into three zones.

\begin{tabular}{|c|c|c|c|c|c|c|c|}
\hline $\begin{array}{l}\text { Sample } \\
\text { No. per } \\
\text { G roup }\end{array}$ & $\begin{array}{l}\text { Depth, } \\
\text { Ft }\end{array}$ & $\begin{array}{l}\text { Predicted K, } \\
\text { mD }\end{array}$ & $\begin{array}{c}\text { Cum.Sum of } K \text {, } \\
\mathrm{mD}\end{array}$ & $\begin{array}{l}\text { Grand Sum Minus } \\
\text { Cum. Sum, mD }\end{array}$ & $B, m D^{2}$ & $\mathrm{~W}, \mathrm{mD}^{2}$ & $\begin{array}{l}\text { Zonation } \\
\text { Index, R }\end{array}$ \\
\hline \multicolumn{8}{|l|}{ Group1 } \\
\hline 1 & 1994 & 0.92 & 0.92 & 47.24 & 12.525 & 0.992 & 0.9208 \\
\hline 2 & 1995 & 1.30 & 2.21 & 45.94 & 14.806 & 0.738 & 0.9501 \\
\hline 3 & 1996 & 1.57 & 3.79 & 44.37 & 16.821 & 0.514 & 0.9694 \\
\hline 4 & 1997 & 2.17 & 5.95 & 42.20 & 17.791 & 0.407 & 0.9771 \\
\hline$* *$ & $* *$ & $* *$ & $* *$ & $* *$ & $* *$ & $* *$ & $* *$ \\
\hline 5 & 1998 & 2.95 & 8.90 & 39.26 & 17.379 & 0.452 & 0.9740 \\
\hline 6 & 1999 & 4.18 & 13.08 & 35.07 & 15.010 & 0.716 & 0.9523 \\
\hline 7 & 2000 & 4.18 & 17.26 & 30.89 & 13.337 & 0.901 & 0.9324 \\
\hline 8 & 2001 & 3.83 & 21.09 & 27.06 & 12.522 & 0.992 & 0.9208 \\
\hline 9 & 2002 & 4.18 & 25.28 & 22.88 & 11.519 & 1.103 & 0.9042 \\
\hline 10 & 2003 & 3.61 & 28.89 & 19.26 & 11.251 & 1.133 & 0.8993 \\
\hline 11 & 2004 & 3.17 & 32.06 & 16.10 & 11.508 & 1.105 & 0.9040 \\
\hline 12 & 2005 & 4.50 & 36.56 & 11.60 & 10.507 & 1.216 & 0.8843 \\
\hline 13 & 2006 & 5.28 & 41.84 & 6.31 & 9.706 & 1.305 & 0.8656 \\
\hline 14 & 2007 & 3.61 & 45.46 & 2.70 & 9.843 & 1.290 & 0.8690 \\
\hline 15 & 2008 & 2.70 & 48.15 & 0 & -- & -- & -- \\
\hline \multicolumn{8}{|l|}{ Group2 } \\
\hline 1 & 2009 & 1.44 & 1.44 & 5.06 & 9.779 & 1.297 & 0.8674 \\
\hline 2 & 2010 & 1.16 & 2.60 & 3.90 & 9.772 & 1.298 & 0.8672 \\
\hline 3 & 2011 & 0.88 & 3.47 & 3.02 & 9.719 & 1.303 & 0.8659 \\
\hline 4 & 2012 & 1.72 & 5.19 & 1.31 & 9.978 & 1.275 & 0.8722 \\
\hline 5 & 2013 & 0.73 & 5.92 & 0.57 & 9.858 & 1.288 & 0.8693 \\
\hline 6 & 2014 & 0.57 & 6.49 & 0 & -- & -- & -- \\
\hline
\end{tabular}


Table E. 19 Flow Unit calculation with Predicted K for well 15-2150 into two zones.

\begin{tabular}{|c|c|c|c|c|c|c|c|}
\hline $\begin{array}{l}\text { Sample } \\
\text { No. per } \\
\text { Group }\end{array}$ & $\begin{array}{l}\text { Depth, } \\
\text { Ft }\end{array}$ & $\begin{array}{l}\text { Predicted K, } \\
\text { mD }\end{array}$ & $\begin{array}{c}\text { Cum.Sum of } K \text {, } \\
\text { mD }\end{array}$ & $\begin{array}{l}\text { G rand Sum M inus } \\
\text { Cum. Sum, mD }\end{array}$ & $B, m^{2}$ & $\mathbf{W}, \mathrm{mD}^{2}$ & $\begin{array}{l}\text { Zonation } \\
\text { Index, R }\end{array}$ \\
\hline 1 & 1870 & 5.36 & 5.36 & 112.14 & 0.738 & 6.449 & $\overline{0}$ \\
\hline 2 & 1871 & 6.30 & 11.66 & 105.85 & 3.718 & 6.325 & 0 \\
\hline 3 & 1872 & 5.60 & 17.26 & 100.24 & 5.166 & 6.265 & 0 \\
\hline 4 & 1873 & 4.31 & 21.57 & 95.94 & 3.598 & 6.330 & 0 \\
\hline 5 & 1874 & 3.61 & 25.18 & 92.32 & 1.654 & 6.411 & 0 \\
\hline 6 & 1875 & 6.77 & 31.96 & 85.55 & 5.073 & 6.269 & 0 \\
\hline 7 & 1876 & 9.34 & 41.30 & 76.21 & 18.250 & 5.720 & 0.6866 \\
\hline 8 & 1877 & 8.43 & 49.73 & 67.77 & 33.282 & 5.093 & 0.8470 \\
\hline 9 & 1878 & 8.07 & 57.81 & 59.70 & 49.865 & 4.402 & 0.9117 \\
\hline 10 & 1879 & 6.68 & 64.48 & 53.02 & 60.445 & 3.961 & 0.9345 \\
\hline 11 & 1880 & 5.77 & 70.25 & 47.26 & 66.450 & 3.711 & 0.9441 \\
\hline 12 & 1881 & 4.18 & 74.43 & 43.07 & 63.139 & 3.849 & 0.9390 \\
\hline 13 & 1882 & 4.18 & 78.61 & 38.89 & 60.688 & 3.951 & 0.9349 \\
\hline 14 & 1883 & 3.78 & 82.39 & 35.12 & 56.564 & 4.123 & 0.9271 \\
\hline 15 & 1884 & 4.37 & 86.76 & 30.75 & 56.695 & 4.118 & 0.9274 \\
\hline 16 & 1885 & 5.60 & 92.36 & 25.14 & 65.332 & 3.758 & 0.9425 \\
\hline 17 & 1886 & 6.77 & 99.14 & 18.37 & 84.550 & 2.957 & 0.9650 \\
\hline 18 & 1887 & 5.60 & 104.74 & 12.77 & 98.767 & 2.365 & 0.9761 \\
\hline 19 & 1888 & 4.37 & 109.11 & 8.40 & 105.573 & 2.081 & 0.9803 \\
\hline$* *$ & $* *$ & $* *$ & $* *$ & $* *$ & $* *$ & $* *$ & $* *$ \\
\hline 20 & 1889 & 2.30 & 111.41 & 6.10 & 95.704 & 2.492 & 0.9740 \\
\hline 21 & 1890 & 1.28 & 112.69 & 4.82 & 78.262 & 3.219 & 0.9589 \\
\hline 22 & 1891 & 1.19 & 113.88 & 3.63 & 61.682 & 3.910 & 0.9366 \\
\hline 23 & 1892 & 1.03 & 114.91 & 2.60 & 45.246 & 4.595 & 0.8985 \\
\hline 24 & 1893 & 1.14 & 116.04 & 1.46 & 31.104 & 5.184 & 0.8333 \\
\hline 25 & 1894 & 0.83 & 116.87 & 0.64 & 15.692 & 5.826 & 0.6287 \\
\hline 26 & 1895 & 0.64 & 117.51 & 0 & -- & -- & -- \\
\hline
\end{tabular}


Table E. 20 Flow U nit calculation with Predicted K for well 15-2215 into two zones.

\begin{tabular}{|c|c|c|c|c|c|c|c|}
\hline $\begin{array}{l}\text { Sample } \\
\text { No. per } \\
\text { G roup }\end{array}$ & $\begin{array}{l}\text { Depth, } \\
\text { Ft }\end{array}$ & $\begin{array}{c}\text { Predicted K, } \\
\text { mD }\end{array}$ & $\underset{\mathrm{mD}}{\text { Cum.Sum of } K \text {, }}$ & $\begin{array}{l}\text { Grand Sum M inus } \\
\text { C um. Sum, mD }\end{array}$ & $B, m^{2}$ & $\mathrm{~W}, \mathrm{mD}^{2}$ & $\begin{array}{l}\text { Zonation } \\
\text { Index, R }\end{array}$ \\
\hline 1 & 1925 & 2.58 & 2.58 & 98.54 & 1.776 & 2.807 & $\overline{0}$ \\
\hline 2 & 1926 & 3.61 & 6.20 & 94.92 & 1.356 & 2.825 & 0 \\
\hline 3 & 1927 & 4.18 & 10.38 & 90.74 & 0.626 & 2.855 & 0 \\
\hline 4 & 1928 & 4.84 & 15.22 & 85.90 & 0.034 & 2.880 & 0 \\
\hline 5 & 1929 & 4.98 & 20.20 & 80.91 & 0.142 & 2.875 & 0 \\
\hline 6 & 1930 & 4.84 & 25.04 & 76.07 & 0.633 & 2.855 & 0 \\
\hline 7 & 1931 & 5.60 & 30.65 & 70.47 & 2.289 & 2.786 & 0 \\
\hline 8 & 1932 & 7.50 & 38.15 & 62.97 & 8.940 & 2.509 & 0.7194 \\
\hline 9 & 1933 & 6.77 & 44.92 & 56.19 & 16.728 & 2.184 & 0.8694 \\
\hline 10 & 1934 & 4.31 & 49.23 & 51.89 & 17.370 & 2.157 & 0.8758 \\
\hline 11 & 1935 & 6.03 & 55.26 & 45.86 & 24.529 & 1.859 & 0.9242 \\
\hline 12 & 1936 & 6.03 & 61.28 & 39.83 & 33.054 & 1.504 & 0.9545 \\
\hline 13 & 1937 & 4.98 & 66.27 & 34.85 & 37.966 & 1.299 & 0.9658 \\
\hline$* *$ & $* *$ & $* *$ & $* *$ & $* *$ & $* *$ & $* *$ & $* *$ \\
\hline 14 & 1938 & 3.12 & 69.39 & 31.73 & 34.556 & 1.441 & 0.9583 \\
\hline 15 & 1939 & 3.46 & 72.85 & 28.27 & 33.187 & 1.498 & 0.9549 \\
\hline 16 & 1940 & 2.58 & 75.43 & 25.69 & 28.338 & 1.700 & 0.9400 \\
\hline 17 & 1941 & 3.67 & 79.10 & 22.02 & 28.646 & 1.688 & 0.9411 \\
\hline 18 & 1942 & 3.03 & 82.13 & 18.99 & 26.553 & 1.775 & 0.9332 \\
\hline 19 & 1943 & 3.12 & 85.25 & 15.86 & 25.229 & 1.830 & 0.9275 \\
\hline 20 & 1944 & 2.70 & 87.95 & 13.17 & 22.406 & 1.948 & 0.9131 \\
\hline 21 & 1945 & 1.96 & 89.91 & 11.21 & 16.798 & 2.181 & 0.8702 \\
\hline 22 & 1946 & 2.44 & 92.34 & 8.77 & 13.593 & 2.315 & 0.8297 \\
\hline 23 & 1947 & 3.36 & 95.70 & 5.41 & 14.734 & 2.267 & 0.8461 \\
\hline 24 & 1948 & 3.56 & 99.27 & 1.85 & 19.018 & 2.089 & 0.8902 \\
\hline 25 & 1949 & 1.36 & 100.62 & 0.50 & 11.979 & 2.382 & 0.8011 \\
\hline 26 & 1950 & 0.50 & 101.12 & 0 & -- & -- & -- \\
\hline
\end{tabular}


Table E. 21 Flow U nit calculation with Predicted K for well 15-2430 into two zones.

\begin{tabular}{|c|c|c|c|c|c|c|c|}
\hline $\begin{array}{l}\text { Sample } \\
\text { No. per } \\
\text { G roup }\end{array}$ & $\begin{array}{l}\text { Depth, } \\
\text { Ft }\end{array}$ & $\begin{array}{l}\text { Predicted K, } \\
\text { mD }\end{array}$ & $\begin{array}{c}\text { C um.Sum of } K \text {, } \\
\mathrm{mD}\end{array}$ & $\begin{array}{l}\text { Grand Sum M inus } \\
\text { Cum. Sum, mD }\end{array}$ & $B, m^{2}$ & $\mathbf{W}, \mathrm{mD}^{2}$ & $\begin{array}{l}\text { Zonation } \\
\text { Index, R }\end{array}$ \\
\hline$\overline{1}$ & 1942 & 0.34 & 0.34 & 64.63 & 11.327 & 3.577 & 0.6842 \\
\hline 2 & 1943 & 0.84 & 1.18 & 63.79 & 20.534 & 3.002 & 0.8538 \\
\hline 3 & 1944 & 1.23 & 2.40 & 62.57 & 28.397 & 2.510 & 0.9116 \\
\hline 4 & 1945 & 2.40 & 4.80 & 60.17 & 29.838 & 2.420 & 0.9189 \\
\hline$* *$ & $* *$ & $* *$ & $* *$ & $* *$ & $* *$ & $* *$ & $* *$ \\
\hline 5 & 1946 & 3.61 & 8.42 & 56.55 & 25.683 & 2.680 & 0.8957 \\
\hline 6 & 1947 & 5.06 & 13.47 & 51.50 & 16.738 & 3.239 & 0.8065 \\
\hline 7 & 1948 & 5.44 & 18.92 & 46.05 & 9.429 & 3.696 & 0.6081 \\
\hline 8 & 1949 & 4.50 & 23.41 & 41.56 & 6.710 & 3.866 & 0.4239 \\
\hline 9 & 1950 & 3.89 & 27.30 & 37.67 & 5.969 & 3.912 & 0.3446 \\
\hline 10 & 1951 & 4.84 & 32.14 & 32.83 & 3.513 & 4.065 & 0 \\
\hline 11 & 1952 & 5.60 & 37.75 & 27.22 & 0.897 & 4.229 & 0 \\
\hline 12 & 1953 & 5.77 & 43.51 & 21.46 & 0.010 & 4.284 & 0 \\
\hline 13 & 1954 & 5.68 & 49.20 & 15.77 & 1.434 & 4.195 & 0 \\
\hline 14 & 1955 & 5.85 & 55.05 & 9.92 & 6.564 & 3.875 & 0.4097 \\
\hline 15 & 1956 & 5.13 & 60.18 & 4.79 & 14.600 & 3.372 & 0.7690 \\
\hline 16 & 1957 & 2.86 & 63.04 & 1.93 & 15.757 & 3.300 & 0.7906 \\
\hline 17 & 1958 & 1.38 & 64.42 & 0.55 & 9.919 & 3.665 & 0.6305 \\
\hline 18 & 1959 & 0.55 & 64.97 & 0 & -- & -- & -- \\
\hline
\end{tabular}


Table E. 22 Flow Unit calculation with Predicted K for well 15-2430 into three zones.

\begin{tabular}{|c|c|c|c|c|c|c|c|}
\hline $\begin{array}{c}\text { Sample } \\
\text { No. per } \\
\text { Group }\end{array}$ & $\begin{array}{l}\text { Depth, } \\
\text { Ft }\end{array}$ & $\begin{array}{l}\text { Predicted K, } \\
\text { mD }\end{array}$ & $\begin{array}{c}\text { C um.Sum of } K, \\
\mathrm{mD}\end{array}$ & $\begin{array}{l}\text { Grand Sum Minus } \\
\text { Cum. Sum, mD }\end{array}$ & $B, m^{2}$ & $\mathrm{~W}, \mathrm{mD}^{2}$ & $\begin{array}{l}\text { Zonation } \\
\text { Index, R }\end{array}$ \\
\hline \multicolumn{8}{|l|}{ Group1 } \\
\hline 1 & 1942 & 0.34 & 0.34 & 4.46 & 15.414 & 2.515 & 0.8368 \\
\hline 2 & 1943 & 0.84 & 1.18 & 3.63 & 15.669 & 2.481 & 0.8416 \\
\hline 3 & 1944 & 1.23 & 2.40 & 2.40 & 15.878 & 2.453 & 0.8455 \\
\hline 4 & 1945 & 2.40 & 4.80 & 0 & -- & -- & -- \\
\hline \multicolumn{8}{|l|}{ Group2 } \\
\hline 1 & 1946 & 3.61 & 3.61 & 56.55 & 15.171 & 2.548 & 0.8321 \\
\hline 2 & 1947 & 5.06 & 8.67 & 51.50 & 14.921 & 2.581 & 0.8270 \\
\hline 3 & 1948 & 5.44 & 14.11 & 46.05 & 15.234 & 2.539 & 0.8333 \\
\hline 4 & 1949 & 4.50 & 18.61 & 41.56 & 15.272 & 2.534 & 0.8341 \\
\hline 5 & 1950 & 3.89 & 22.50 & 37.67 & 15.078 & 2.560 & 0.8302 \\
\hline 6 & 1951 & 4.84 & 27.34 & 32.83 & 15.271 & 2.534 & 0.8340 \\
\hline 7 & 1952 & 5.60 & 32.94 & 27.22 & 16.086 & 2.426 & 0.8492 \\
\hline 8 & 1953 & 5.77 & 38.71 & 21.46 & 17.652 & 2.217 & 0.8744 \\
\hline 9 & 1954 & 5.68 & 44.40 & 15.77 & 20.002 & 1.904 & 0.9048 \\
\hline 10 & 1955 & 5.85 & 50.25 & 9.92 & 24.173 & 1.347 & 0.9443 \\
\hline 11 & 1956 & 5.13 & 55.38 & 4.79 & 28.857 & 0.723 & 0.9749 \\
\hline$* *$ & $* *$ & $* *$ & $* *$ & $* *$ & $* *$ & $* *$ & $* *$ \\
\hline 12 & 1957 & 2.86 & 58.24 & 1.93 & 27.891 & 0.852 & 0.9695 \\
\hline 13 & 1958 & 1.38 & 59.62 & 0.55 & 22.487 & 1.572 & 0.9301 \\
\hline 14 & 1959 & 0.55 & 60.17 & 0 & -- & -- & -- \\
\hline
\end{tabular}


Table E. 23 Flow U nit calculation with Predicted K for well 15-2001 into two zones.

\begin{tabular}{|c|c|c|c|c|c|c|c|}
\hline $\begin{array}{l}\text { Sample } \\
\text { No. per } \\
\text { G roup }\end{array}$ & $\begin{array}{l}\text { Depth, } \\
\text { Ft }\end{array}$ & $\begin{array}{l}\text { Predicted K, } \\
\text { mD }\end{array}$ & $\underset{\mathrm{mD}}{\text { Cum.Sum of } K \text {, }}$ & $\begin{array}{l}\text { G rand Sum M inus } \\
\text { Cum. Sum, mD }\end{array}$ & $B, \mathrm{mD}^{2}$ & $\mathrm{~W}, \mathrm{mD}^{2}$ & $\begin{array}{l}\text { Zonation } \\
\text { Index, R }\end{array}$ \\
\hline 1 & 2186 & 0.79 & 0.79 & 16.71 & 0.002 & 0.072 & 0 \\
\hline 2 & 2187 & 1.19 & 1.98 & 15.52 & 0.054 & 0.069 & 0 \\
\hline 3 & 2188 & 1.06 & 3.04 & 14.47 & 0.113 & 0.066 & 0.4172 \\
\hline 4 & 2189 & 1.19 & 4.23 & 13.27 & 0.248 & 0.059 & 0.7628 \\
\hline 5 & 2190 & 1.11 & 5.34 & 12.17 & 0.359 & 0.053 & 0.8523 \\
\hline$* *$ & $* *$ & $* *$ & $* *$ & $* *$ & $* *$ & $* *$ & $* *$ \\
\hline 6 & 2191 & 0.64 & 5.97 & 11.53 & 0.220 & 0.060 & 0.7255 \\
\hline 7 & 2192 & 0.49 & 6.46 & 11.05 & 0.084 & 0.067 & 0.1939 \\
\hline 8 & 2193 & 0.42 & 6.88 & 10.62 & 0.009 & 0.071 & 0 \\
\hline 9 & 2194 & 0.68 & 7.56 & 9.94 & 0.001 & 0.072 & 0 \\
\hline 10 & 2195 & 0.71 & 8.28 & 9.23 & 0.001 & 0.072 & 0 \\
\hline 11 & 2196 & 0.79 & 9.07 & 8.44 & 0.002 & 0.072 & 0 \\
\hline 12 & 2197 & 0.96 & 10.03 & 7.48 & 0.000 & 0.072 & 0 \\
\hline 13 & 2198 & 0.90 & 10.93 & 6.58 & 0.002 & 0.072 & 0 \\
\hline 14 & 2199 & 0.94 & 11.87 & 5.64 & 0.009 & 0.071 & 0 \\
\hline 15 & 2200 & 1.11 & 12.98 & 4.53 & 0.052 & 0.069 & 0 \\
\hline 16 & 2201 & 1.14 & 14.12 & 3.39 & 0.159 & 0.064 & 0.6001 \\
\hline 17 & 2202 & 0.89 & 15.00 & 2.50 & 0.214 & 0.061 & 0.7172 \\
\hline 18 & 2203 & 0.94 & 15.95 & 1.56 & 0.345 & 0.054 & 0.8442 \\
\hline 19 & 2204 & 0.77 & 16.71 & 0.79 & 0.424 & 0.050 & 0.8431 \\
\hline 20 & 2205 & 0.48 & 17.19 & 0.31 & 0.287 & 0.057 & 0.8027 \\
\hline 21 & 2206 & 0.31 & 17.51 & 0 & -- & -- & -- \\
\hline
\end{tabular}


Table E. 24 Flow Unit calculation with Predicted K for well 15-2001 into three zones.

\begin{tabular}{|c|c|c|c|c|c|c|c|}
\hline $\begin{array}{c}\text { Sample } \\
\text { No. per } \\
\text { G roup }\end{array}$ & $\begin{array}{c}\text { Depth, } \\
\text { Ft }\end{array}$ & $\begin{array}{l}\text { Predicted K, } \\
\text { mD }\end{array}$ & $\begin{array}{c}\text { Cum.Sum of } K \text {, } \\
\text { mD }\end{array}$ & $\begin{array}{l}\text { Grand Sum Minus } \\
\text { Cum. Sum, mD }\end{array}$ & $B, m^{2}$ & $\mathrm{~W}, \mathrm{mD}^{2}$ & $\begin{array}{l}\text { Zonation } \\
\text { Index, R }\end{array}$ \\
\hline \multicolumn{8}{|l|}{ Group1 } \\
\hline 1 & 2186 & 0.79 & 0.79 & 4.55 & 0.227 & 0.051 & 0.77722 \\
\hline 2 & 2187 & 1.19 & 1.98 & 3.36 & 0.189 & 0.055 & 0.71014 \\
\hline 3 & 2188 & 1.06 & 3.04 & 2.30 & 0.190 & 0.055 & 0.7125 \\
\hline 4 & 2189 & 1.19 & 4.23 & 1.11 & 0.180 & 0.056 & 0.6904 \\
\hline 5 & 2190 & 1.11 & 5.34 & 0 & -- & -- & -- \\
\hline \multicolumn{8}{|l|}{ Group2 } \\
\hline 1 & 2191 & 0.64 & 0.64 & 11.53 & 0.188 & 0.055 & 0.7070 \\
\hline 2 & 2192 & 0.49 & 1.12 & 11.05 & 0.225 & 0.051 & 0.7733 \\
\hline 3 & 2193 & 0.42 & 1.54 & 10.62 & 0.291 & 0.044 & 0.8501 \\
\hline 4 & 2194 & 0.68 & 2.23 & 9.94 & 0.290 & 0.044 & 0.8493 \\
\hline 5 & 2195 & 0.71 & 2.94 & 9.23 & 0.287 & 0.044 & 0.8469 \\
\hline 6 & 2196 & 0.79 & 3.73 & 8.44 & 0.271 & 0.046 & 0.8315 \\
\hline 7 & 2197 & 0.96 & 4.69 & 7.48 & 0.231 & 0.050 & 0.7821 \\
\hline 8 & 2198 & 0.90 & 5.59 & 6.58 & 0.210 & 0.053 & 0.7496 \\
\hline 9 & 2199 & 0.94 & 6.53 & 5.64 & 0.192 & 0.055 & 0.7154 \\
\hline 10 & 2200 & 1.11 & 7.64 & 4.53 & 0.179 & 0.056 & 0.6885 \\
\hline 11 & 2201 & 1.14 & 8.78 & 3.39 & 0.204 & 0.053 & 0.7394 \\
\hline 12 & 2202 & 0.89 & 9.67 & 2.50 & 0.228 & 0.051 & 0.7785 \\
\hline 13 & 2203 & 0.94 & 10.61 & 1.56 & 0.286 & 0.044 & 0.8462 \\
\hline 14 & 2204 & 0.77 & 11.38 & 0.79 & 0.331 & 0.039 & 0.8822 \\
\hline$* *$ & $* *$ & $* *$ & $* *$ & $* *$ & $* *$ & $* *$ & $* *$ \\
\hline 15 & 2205 & 0.48 & 11.86 & 0.31 & 0.287 & 0.044 & 0.8472 \\
\hline 16 & 2206 & 0.31 & 12.17 & 0 & -- & -- & -- \\
\hline
\end{tabular}


Table E. 25 Flow Unit calculation with Predicted K for well 87-2102 into two zones.

\begin{tabular}{|c|c|c|c|c|c|c|c|}
\hline $\begin{array}{c}\text { Sample } \\
\text { No. per } \\
\text { G roup }\end{array}$ & $\begin{array}{l}\text { Depth, } \\
\text { Ft }\end{array}$ & $\begin{array}{l}\text { Predicted K, } \\
\text { mD }\end{array}$ & $\begin{array}{c}\text { C um.Sum of } K \text {, } \\
\text { mD }\end{array}$ & $\begin{array}{l}\text { Grand Sum Minus } \\
\text { Cum. Sum, mD }\end{array}$ & $B, m^{2}$ & $\mathbf{W}, \mathrm{mD}^{2}$ & $\begin{array}{c}\text { Zonation Index, } \\
\mathbf{R}\end{array}$ \\
\hline 1 & 1989 & 3.36 & 3.36 & 55.70 & 0.174 & 3.218 & $\overline{0}$ \\
\hline 2 & 1990 & 2.99 & 6.35 & 52.71 & 0.109 & 3.221 & 0 \\
\hline 3 & 1991 & 6.68 & 13.02 & 46.03 & 6.804 & 2.849 & 0.5812 \\
\hline 4 & 1992 & 6.58 & 19.60 & 39.45 & 18.972 & 2.173 & 0.8854 \\
\hline 5 & 1993 & 5.52 & 25.12 & 33.93 & 28.619 & 1.637 & 0.9428 \\
\hline 6 & 1994 & 4.63 & 29.76 & 29.30 & 34.514 & 1.310 & 0.9620 \\
\hline 7 & 1995 & 4.06 & 33.82 & 25.24 & 37.999 & 1.116 & 0.9706 \\
\hline 8 & 1996 & 3.51 & 37.33 & 21.73 & 39.136 & 1.053 & 0.9731 \\
\hline$* *$ & $* *$ & $* *$ & $* *$ & $* *$ & $* *$ & $* *$ & $* *$ \\
\hline 9 & 1997 & 2.30 & 39.63 & 19.43 & 34.408 & 1.316 & 0.9618 \\
\hline 10 & 1998 & 2.23 & 41.86 & 17.20 & 30.401 & 1.539 & 0.9494 \\
\hline 11 & 1999 & 2.26 & 44.12 & 14.94 & 27.373 & 1.707 & 0.9377 \\
\hline 12 & 2000 & 2.37 & 46.49 & 12.57 & 25.452 & 1.813 & 0.9288 \\
\hline 13 & 2001 & 2.30 & 48.78 & 10.27 & 23.761 & 1.907 & 0.9197 \\
\hline 14 & 2002 & 2.30 & 51.08 & 7.97 & 22.598 & 1.972 & 0.9127 \\
\hline 15 & 2003 & 2.07 & 53.16 & 5.90 & 20.950 & 2.064 & 0.9015 \\
\hline 16 & 2004 & 1.85 & 55.00 & 4.06 & 18.799 & 2.183 & 0.8839 \\
\hline 17 & 2005 & 1.36 & 56.36 & 2.70 & 14.885 & 2.401 & 0.8387 \\
\hline 18 & 2006 & 1.19 & 57.55 & 1.51 & 10.747 & 2.630 & 0.7553 \\
\hline 19 & 2007 & 0.81 & 58.36 & 0.69 & 5.375 & 2.929 & 0.4551 \\
\hline 20 & 2008 & 0.69 & 59.06 & 0 & -- & -- & -- \\
\hline
\end{tabular}




\section{APPENDIX F \\ Sample Calculation for correlation of flow units for both cored wells and wells without cores.}


F 1. Sample C alculation to identify flow unit for well 15-733:

V ariance between zones:

B $\frac{1}{\mathrm{~L} 1}{ }_{i 1}^{\mathrm{L}} \mathrm{m}_{\mathrm{i}}\left(\overline{\mathrm{k}}_{\mathrm{i}} \overline{\mathrm{k}}_{. .}\right)^{2}$

B $\frac{1}{21}\left[\frac{4.9^{2}}{1} \quad \frac{(4.25)^{2}}{92} \quad \frac{(9.15)^{2}}{9} \quad 16.965\right.$

Variance within zones:

$$
\begin{aligned}
& W \quad \frac{1}{N \quad L} m_{i 1}^{m_{j 1}^{m_{i}}}\left(\bar{k}_{i} \bar{k}_{. .}\right)^{2} \\
& \text { W } \frac{1}{92}\left[\begin{array}{llll}
4.9^{2} & (1.2)^{2} & (2.7)^{2} \quad \ldots \ldots \ldots \ldots \ldots \ldots . . . & (0.05)^{2}
\end{array}\right. \\
& \left.\frac{(4.9)^{2}}{1} \quad \frac{(4.25)^{2}}{9 \quad 1}\right] \quad 0.93
\end{aligned}
$$

The zonation index:

$$
\begin{aligned}
& R \frac{B \quad W}{B} \\
& R \frac{16.965 \quad 0.93}{16.965} 0.9453
\end{aligned}
$$


F2.Sample calculation for flow unit correlation from well to well using ten cored well data:

The correlation of flow units is performed as follows:

1. Rank well zone means in the order of decreasing magnitude of permeability as shown below.

Table F.1 Rank of measured C ore Permeability M eans for ten cor ed wells in the order of decreasing magnitude.

$\begin{array}{ccc}\text { Zone No. } & \text { Zone Mean } & \text { No. of Data Points } \\ 3-1108 & 17.00 & 2 \\ 2-1108 & 10.38 & 4 \\ 2-1107 & 9.68 & 4 \\ 1-1309 & 6.61 & 13 \\ 1-1132 & 6.53 & 7 \\ 1-1130 & 5.99 & 11 \\ 4-1108 & 5.83 & 9 \\ 2-1184 & 5.18 & 12 \\ 1-733 & 4.90 & 1 \\ 1-1128 & 3.10 & 1 \\ 2-1130 & 3.08 & 4 \\ 1-1184 & 2.50 & 4 \\ 3-1107 & 2.46 & 3 \\ 1-1108 & 2.05 & 4 \\ 3-1184 & 2.00 & 9 \\ 2-733 & 1.95 & 2 \\ 2-1128 & 1.50 & 3 \\ 2-1132 & 1.26 & 7 \\ 1-1107 & 1.24 & 5 \\ 2-1309 & 1.17 & 3 \\ 3-1128 & 0.49 & 5 \\ 1-1109 & 0.25 & 3 \\ 1-1059 & 0.24 & 4 \\ 3-733 & 0.06 & 6 \\ 2-1109 & 0.05 & 3\end{array}$


2. Calculate with Eq. 2 using all the permeability data in the entire reservoir.

$$
\begin{aligned}
& \text { W } \frac{1}{129 \quad 25}\left[\begin{array}{llll}
4.9^{2} & (1.2)^{2} & (2.7)^{2} \quad \ldots \ldots \ldots \ldots \ldots \ldots & (0.5)^{2}
\end{array}\right. \\
& \left.\frac{(4.9)^{2}}{1} \quad \frac{(3.9)^{2}}{2} \quad \ldots \ldots \ldots \ldots . . . \frac{(3.5)^{2}}{3}\right] \quad 8.0238
\end{aligned}
$$

3. Calculate the standard deviation from step 2

$$
\text { S } \sqrt{8.0238} \quad 2.8326
$$

4. Select the $\mathrm{Z}$-Values ${ }^{9}$ for a $99 \%$ probability level $\left(\mathrm{Z}_{\mathrm{v}, \mathrm{p}}\right)$

$\begin{array}{ccccccccc}\mathrm{P} & 2 & 3 & 4 & 5 & 6 & 7 & 8 & 9 \\ \mathrm{Zv}, \mathrm{p} & 3.7180 & 3.8751 & 3.9826 & 4.0619 & 4.1249 & 4.1761 & 4.2201 & 4.2571 \\ & & & & & & & & \\ & 10 & 11 & 12 & 13 & 14 & 15 & 16 & 17 \\ & 4.2901 & 4.3189 & 4.3449 & 4.3686 & 4.3896 & 4.4091 & 4.4271 & 4.4431 \\ & 18 & 19 & 20 & 21 & 22 & 23 & 24 & 25 \\ & 4.4585 & 4.4725 & 5.1567 & 5.1942 & 5.2317 & 5.2653 & 5.2988 & 5.3297\end{array}$

5. Multiply the Z-values in step-4 by the standard deviation in step-3

$\begin{array}{ccccccccc}\mathrm{P} & 2 & 3 & 4 & 5 & 6 & 7 & 8 & 9 \\ \mathrm{~F}^{\prime} \mathrm{p}=\mathrm{SZ} \mathrm{v}_{v} \mathrm{p} & 10.5316 & 10.9765 & 11.2811 & 11.5056 & 11.6841 & 11.8293 & 11.9539 & 12.0588 \\ & 10 & 11 & 12 & 13 & 14 & 15 & 16 & 17 \\ & 12.1522 & 12.2336 & 12.3073 & 12.3745 & 12.4340 & 12.4891 & 12.5401 & 12.5854 \\ & 18 & 19 & 20 & 21 & 22 & 23 & 24 & 25 \\ & 12.6292 & 12.6689 & 14.6068 & 14.7131 & 14.8194 & 14.9144 & 15.0094 & 15.0969\end{array}$

6. Test the significant differences among well-flow unit means. First, the largest mean is compared with each of the smaller means. In order for the means of flow unit 3 of 15-1108 and flow unit 2 of 15-1109 to be significantly different.

$$
\left(\begin{array}{ll}
17 & 0.05
\end{array}\right) \sqrt{\frac{2(2)(3)}{23}} \quad 26.258
$$

must be greater than $\mathrm{FL}_{25}=15.10$. Since the condition is satisfied, flow unit 3 of 15-1108 and flow unit 2 of 15-1109 represented by the means $17 \mathrm{mD}$ and 0.05 $\mathrm{mD}$ are significantly different. 
Table F. 2 Comparison of the mean of flow unit 3 of well 15-1108.

\begin{tabular}{cccccc} 
Flow & Wore & Corm & Number of & F'p for & \\
Unit & Well & $\begin{array}{c}\text { (mD) } \\
\text { (mata in Zone }\end{array}$ & $\mathbf{1 7 . 0 0}$ & F'p \\
\hline 3 & $15-1108$ & 17.00 & 2 & 0 & \\
2 & $15-1108$ & 10.38 & 4 & 10.82 & 10.53 \\
2 & $15-1107$ & 9.68 & 4 & 11.96 & 10.98 \\
1 & $15-1309$ & 6.61 & 13 & 19.35 & 11.28 \\
1 & $15-1132$ & 6.53 & 7 & 18.47 & 11.51 \\
1 & $15-1130$ & 5.99 & 11 & 20.25 & 11.68 \\
4 & $15-1108$ & 5.83 & 9 & 20.20 & 11.83 \\
2 & $15-1184$ & 5.18 & 12 & 21.88 & 11.95 \\
1 & $15-733$ & 4.90 & 1 & 13.97 & 12.06 \\
1 & $15-1128$ & 3.10 & 1 & 16.05 & 12.15 \\
2 & $15-1130$ & 3.08 & 4 & 22.74 & 12.23 \\
1 & $15-1184$ & 2.50 & 4 & 23.68 & 12.31 \\
3 & $15-1107$ & 2.46 & 3 & 22.53 & 12.37 \\
1 & $15-1108$ & 2.05 & 4 & 24.41 & 12.43 \\
3 & $15-1184$ & 2.00 & 9 & 27.14 & 12.49 \\
2 & $15-733$ & 1.95 & 2 & 21.28 & 12.54 \\
2 & $15-1128$ & 1.50 & 3 & 24.01 & 12.59 \\
2 & $15-1132$ & 1.26 & 7 & 27.76 & 12.63 \\
1 & $15-1107$ & 1.24 & 5 & 26.64 & 12.67 \\
2 & $15-1309$ & 1.17 & 3 & 24.53 & 14.61 \\
3 & $15-1128$ & 0.49 & 5 & 27.91 & 14.71 \\
1 & $15-1109$ & 0.25 & 3 & 25.95 & 14.82 \\
1 & $15-1059$ & 0.24 & 4 & 27.37 & 14.91 \\
3 & $15-733$ & 0.06 & 6 & 29.34 & 15.01 \\
2 & $15-1109$ & 0.05 & 3 & 26.26 & 15.10
\end{tabular}

At the completion of the test, the mean of flow unit 3 of 15-1108 is compared with the mean of the other zones and found that the flow unit 3 of $15-1108$ is significantly different from the means of the other zones. In the next step, the next largest mean of flow unit 2 of 15-1108 is compared with the smallest mean flow unit 2 of 15-1109.

$$
\left(\begin{array}{ll}
10.38 & 0.05) \\
\sqrt{\frac{2(4)(3)}{4 \quad 3}} & 19.1189
\end{array}\right.
$$


Table F. 3 C omparison of the mean of flow unit 2 of well 15-1108.

\begin{tabular}{cccccc}
$\begin{array}{c}\text { Flow } \\
\text { Unit }\end{array}$ & W ell & $\begin{array}{c}\text { Core } \\
\text { (mD) }\end{array}$ & $\begin{array}{c}\text { Number of } \\
\text { Data in Zone }\end{array}$ & $\begin{array}{c}\text { F'p for } \\
\mathbf{1 0 . 3 8}\end{array}$ & F'p $^{\prime}$ \\
\hline 3 & $15-1108$ & 17.00 & 2 & -- & -- \\
2 & $15-1108$ & 10.38 & 4 & 0 & \\
2 & $15-1107$ & 9.68 & 4 & 1.40 & 10.53 \\
1 & $15-1309$ & 6.61 & 13 & 9.32 & 10.98 \\
1 & $15-1132$ & 6.53 & 7 & 8.68 & 11.28 \\
1 & $15-1130$ & 5.99 & 11 & 10.62 & 11.51 \\
4 & $15-1108$ & 5.83 & 9 & 10.69 & 11.68 \\
2 & $15-1184$ & 5.18 & 12 & 12.72 & 11.83 \\
1 & $15-733$ & 4.90 & 1 & 6.93 & 11.95 \\
1 & $15-1128$ & 3.10 & 1 & $\mathbf{9 . 2 0}$ & $\mathbf{1 2 . 0 6}$ \\
\hline \hline 2 & $15-1130$ & 3.08 & 4 & 14.60 & 12.15 \\
1 & $15-1184$ & 2.50 & 4 & 15.75 & 12.23 \\
3 & $15-1107$ & 2.46 & 3 & 14.66 & 12.31 \\
1 & $15-1108$ & 2.05 & 4 & 16.65 & 12.37 \\
3 & $15-1184$ & 2.00 & 9 & 19.71 & 12.43 \\
2 & $15-733$ & 1.95 & 2 & 13.76 & 12.49 \\
2 & $15-1128$ & 1.50 & 3 & 16.43 & 12.54 \\
2 & $15-1132$ & 1.26 & 7 & 20.56 & 12.59 \\
1 & $15-1107$ & 1.24 & 5 & 19.26 & 12.63 \\
2 & $15-1309$ & 1.17 & 3 & 17.05 & 12.67 \\
3 & $15-1128$ & 0.49 & 5 & 20.84 & 14.61 \\
1 & $15-1109$ & 0.25 & 3 & 18.75 & 14.71 \\
1 & $15-1059$ & 0.24 & 4 & 20.28 & 14.82 \\
3 & $15-733$ & 0.06 & 6 & 22.60 & 14.91 \\
2 & $15-1109$ & 0.05 & 3 & 19.12 & 15.01 \\
& & & & & \\
\hline
\end{tabular}

In the next step, the mean of flow unit 2 of $15-1108$ is compared with the mean of the other zones until the difference is not significant. We find the comparisons are significant until flow unit 1 of $15-1128$ is reached.

$$
\left(\begin{array}{ll}
10.38 & 3.1)
\end{array} \sqrt{\frac{2(4)(1)}{4 \quad 1}} \quad 9.2022 \quad F_{10}^{\prime}(12.06)\right.
$$


Then the next largest mean is compared with the smaller mean as follows.

Table F .4 Comparison of the mean of flow unit 2 of well 15-1130.

\begin{tabular}{cccccc}
$\begin{array}{c}\text { Flow } \\
\text { Unit }\end{array}$ & W ell & $\begin{array}{c}\text { Core } \\
\text { Perm } \\
\text { (mD) }\end{array}$ & $\begin{array}{c}\text { Number of } \\
\text { Data in Zone }\end{array}$ & $\begin{array}{c}\text { F'p for } \\
\mathbf{3 . 0 8}\end{array}$ & F'p $^{\prime}$ \\
\hline 2 & $15-1130$ & 3.08 & 4 & 0 & \\
1 & $15-1184$ & 2.50 & 4 & 1.15 & 10.53 \\
3 & $15-1107$ & 2.46 & 3 & 1.14 & 10.98 \\
1 & $15-1108$ & 2.05 & 4 & 2.05 & 11.28 \\
3 & $15-1184$ & 2.00 & 9 & 2.53 & 11.51 \\
2 & $15-733$ & 1.95 & 2 & 1.84 & 11.68 \\
2 & $15-1128$ & 1.50 & 3 & 2.92 & 11.83 \\
2 & $15-1132$ & 1.26 & 7 & 4.09 & 11.95 \\
1 & $15-1107$ & 1.24 & 5 & 3.87 & 12.06 \\
2 & $15-1309$ & 1.17 & 3 & 3.53 & 12.15 \\
3 & $15-1128$ & 0.49 & 5 & 5.45 & 12.23 \\
1 & $15-1109$ & 0.25 & 3 & 5.23 & 12.31 \\
1 & $15-1059$ & 0.24 & 4 & 5.68 & 12.37 \\
3 & $15-733$ & 0.06 & 6 & 6.61 & 12.43 \\
2 & $15-1109$ & 0.05 & 3 & 5.60 & 12.49
\end{tabular}

The calculations are carried out until a non significant difference is found.

$$
\left(\begin{array}{ll}
3.08 & 0.05) \\
\frac{2(4)(3)}{4 \quad 3} & 5.60 \quad F_{15}^{\prime}(12.49)
\end{array}\right.
$$


The means which are not significantly different are distinguished as follows.

Table F . 5 Final divisions of core permeability means into two groups.

\begin{tabular}{cc}
$\begin{array}{c}\text { Group 1 } \\
\text { Flow Unit }\end{array}$ & Well \\
\hline 3 & $15-1108$ \\
2 & $15-1108$ \\
2 & $15-1107$ \\
1 & $15-1309$ \\
1 & $15-1132$ \\
1 & $15-1130$ \\
4 & $15-1108$ \\
2 & $15-1184$ \\
1 & $15-733$ \\
1 & $15-1128$
\end{tabular}

\begin{tabular}{cc}
$\begin{array}{c}\text { Group } 2 \\
\text { Flow Unit }\end{array}$ & Well \\
\hline 2 & $15-1130$ \\
1 & $15-1184$ \\
3 & $15-1107$ \\
1 & $15-1108$ \\
3 & $15-1184$ \\
2 & $15-733$ \\
2 & $15-1128$ \\
2 & $15-1132$ \\
1 & $15-1107$ \\
2 & $15-1309$ \\
3 & $15-1128$ \\
1 & $15-1109$ \\
1 & $15-1059$ \\
3 & $15-733$ \\
2 & $15-1109$
\end{tabular}


F3. Sample calculation for flow unit correlation from well to well using fifteen well data without cores:

The correlation of flow units is performed as follows:

1. Rank well zone means in the order of decreasing magnitude of permeability as shown below.

Table F .6 R ank of predicted permeability M eans for fifteen wells with no cores in the order of decreasing magnitude.

\begin{tabular}{|c|c|c|}
\hline Zone & Zone Mean & No. of Data in zone \\
\hline $1-1176$ & 7.11 & 17 \\
\hline $2-1243$ & 6.80 & 15 \\
\hline $2-1225$ & 6.12 & 12 \\
\hline 2150-1 & 5.74 & 19 \\
\hline 2215-1 & 5.1 & 13 \\
\hline $2430-2$ & 5.03 & 11 \\
\hline 1-87-2102 & 4.67 & 8 \\
\hline $2-1783$ & 3.84 & 11 \\
\hline $2-1621$ & 3.43 & 7 \\
\hline $2-1639$ & 3.19 & 15 \\
\hline $2215-2$ & 2.68 & 13 \\
\hline 2-87-2102 & 1.81 & 12 \\
\hline $1-1621$ & 1.80 & 10 \\
\hline $3-1243$ & 1.80 & 4 \\
\hline 3-1225 & 1.71 & 7 \\
\hline $2430-3$ & 1.6 & 3 \\
\hline $1-1783$ & 1.49 & 4 \\
\hline $1-868$ & 1.48 & 8 \\
\hline $1-1639$ & 1.33 & 7 \\
\hline $2150-2$ & 1.2 & 7 \\
\hline 2430- 1 & 1.2 & 4 \\
\hline $1-1243$ & 1.12 & 4 \\
\hline $2-1176$ & 1.10 & 7 \\
\hline $3-1783$ & 1.08 & 6 \\
\hline $1-2001$ & 1.07 & 5 \\
\hline $3-1639$ & 0.93 & 5 \\
\hline $1-1225$ & 0.85 & 5 \\
\hline $2-2001$ & 0.81 & 14 \\
\hline 3-1621 & 0.71 & 6 \\
\hline $1-1649$ & 0.67 & 9 \\
\hline $1-1110$ & 0.62 & 3 \\
\hline $1-874$ & 0.61 & 3 \\
\hline $2-868$ & 0.45 & 3 \\
\hline $3-2001$ & 0.40 & 2 \\
\hline $2-1110$ & 0.23 & 7 \\
\hline $2-1649$ & 0.14 & 7 \\
\hline $2-874$ & 0.13 & 10 \\
\hline
\end{tabular}


2. Calculate with Eq. 2 using all the permeability data in the entire reservoir.

$$
\begin{aligned}
& \text { W } \frac{1}{303 \quad 37}\left[\begin{array}{llll}
1.44^{2} & \left.(1.3)^{2}(1.90)^{2} \quad \ldots \ldots \ldots \ldots \ldots . . . . . . . .310\right)^{2}
\end{array}\right. \\
& \left.\frac{(11.85)^{2}}{8} \quad \frac{(1.35)^{2}}{3} \quad \ldots \ldots \ldots \ldots . . . . . \frac{(0.791)^{2}}{2}\right] 1.0256
\end{aligned}
$$

3. Calculate the standard deviation from step 2

$$
\begin{array}{lll}
\text { S } & \sqrt{1.0256} & 1.0127
\end{array}
$$

\begin{tabular}{|c|c|c|c|c|c|c|c|c|}
\hline$\stackrel{P}{Z v, p}$ & $\begin{array}{c}2 \\
3.643\end{array}$ & $\begin{array}{c}3 \\
3.796\end{array}$ & $\begin{array}{c}4 \\
3.9\end{array}$ & $\begin{array}{c}5 \\
3.978\end{array}$ & $\begin{array}{c}6 \\
4.04\end{array}$ & $\begin{array}{c}7 \\
4.091\end{array}$ & $\begin{array}{c}8 \\
4.135\end{array}$ & $\begin{array}{c}9 \\
4.172\end{array}$ \\
\hline & $\begin{array}{c}10 \\
4.205\end{array}$ & $\begin{array}{c}11 \\
4.235\end{array}$ & $\begin{array}{c}12 \\
4.261\end{array}$ & $\begin{array}{c}13 \\
4.285\end{array}$ & $\begin{array}{c}14 \\
4.307\end{array}$ & $\begin{array}{c}15 \\
4.327\end{array}$ & $\begin{array}{c}16 \\
4.345\end{array}$ & $\begin{array}{c}17 \\
4.363\end{array}$ \\
\hline & $\begin{array}{c}18 \\
4.379\end{array}$ & $\begin{array}{c}19 \\
4.394\end{array}$ & $\begin{array}{c}20 \\
5.012\end{array}$ & $\begin{array}{c}21 \\
5.0465\end{array}$ & $\begin{array}{c}22 \\
5.081\end{array}$ & $\begin{array}{c}23 \\
5.1125\end{array}$ & $\begin{array}{c}24 \\
5.144\end{array}$ & $\begin{array}{c}25 \\
2.572\end{array}$ \\
\hline & $\begin{array}{c}26 \\
5.201\end{array}$ & $\begin{array}{c}27 \\
5.227\end{array}$ & $\begin{array}{c}28 \\
5.253\end{array}$ & $\begin{array}{c}29 \\
5.277\end{array}$ & $\begin{array}{c}30 \\
5.301\end{array}$ & $\begin{array}{c}31 \\
5.3235\end{array}$ & $\begin{array}{c}32 \\
5.346\end{array}$ & $\begin{array}{c}33 \\
2.673\end{array}$ \\
\hline & $\begin{array}{c}34 \\
5.388\end{array}$ & $\begin{array}{c}35 \\
5.4075\end{array}$ & $\begin{array}{c}36 \\
5.427\end{array}$ & $\begin{array}{c}37 \\
2.7135\end{array}$ & & & & \\
\hline
\end{tabular}

4. Select the $\mathrm{Z}$-Values ${ }^{9}$ for a $99 \%$ probability level $\left(\mathrm{Z}_{\mathrm{v}, \mathrm{p}}\right)$

5. Multiply the Z-values in step-4 by the standard deviation in step-3

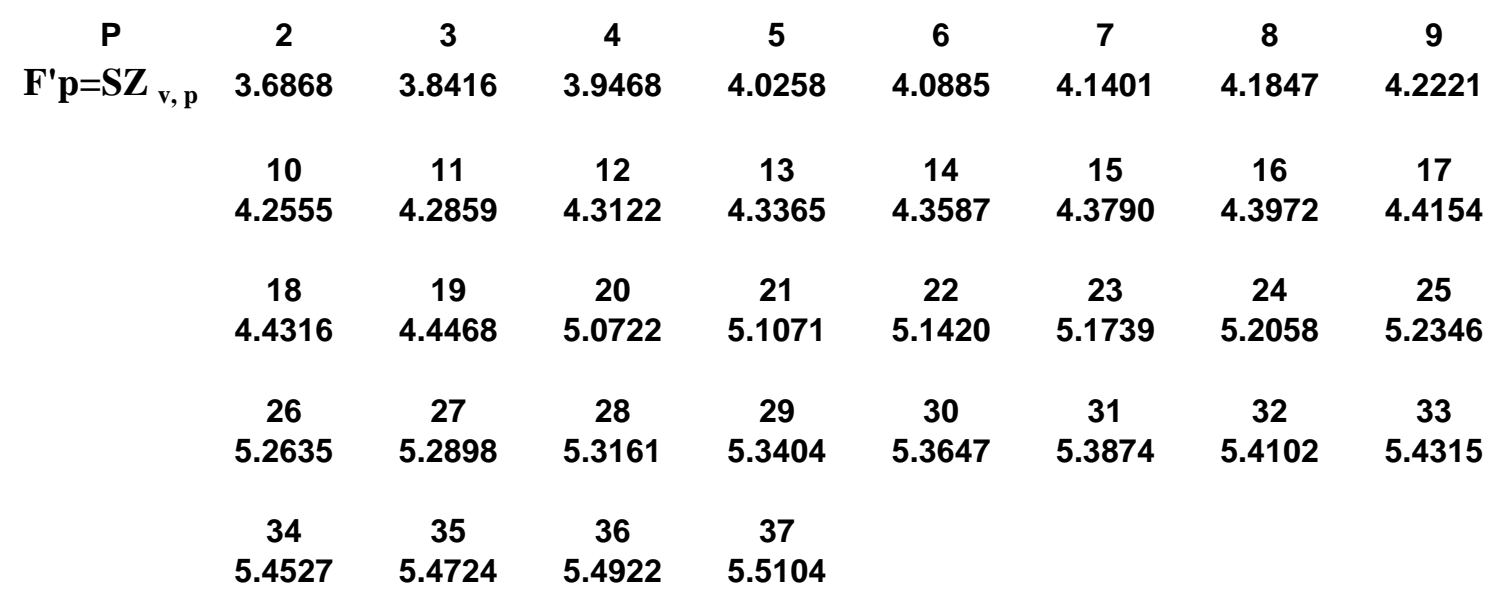


6. Test the significant differences among well-flow unit means. First, the largest mean is compared with each of the smaller means. In order for the means of flow unit 1 of 1176 and flow unit 2 of 874 to be significantly different.

$$
\left(\begin{array}{ll}
7.11 & 0.13
\end{array}\right) \sqrt{\frac{2(17)(10)}{17 \quad 10}} \quad 24.767
$$

must be greater than $\mathrm{F}_{37}=5.5104$ Since the condition is satisfied, flow unit 1 of 15-1176 and flow unit 2 of 15-874 represented by the means $7.11 \mathrm{mD}$ and 0.13 $\mathrm{mD}$ are significantly different.

After the test is completed, the mean of flow unit 1 of $15-1176$ is compared with the mean of the other flow units until the difference is not significant. It was found that the comparisons are significant until flow unit 2 of $15-1225$ is reached as shown in Table C.7. 
Table F 7 C omparison of the mean of flow unit 1 of well 15-1176.

\begin{tabular}{|c|c|c|c|c|c|}
\hline Flow Unit & W ell & $\begin{array}{c}\text { Predicted } \\
\text { Perm (mD) }\end{array}$ & $\begin{array}{c}\text { Number of Data } \\
\text { in Zone }\end{array}$ & $\begin{array}{c}\text { F'p for } \\
7.11\end{array}$ & $F^{\prime} p$ \\
\hline 1 & $15-1176$ & 7.11 & 17 & & \\
\hline 2 & $15-1243$ & 6.80 & 15 & 1.22 & 3.69 \\
\hline 2 & $15-1225$ & 6.12 & 12 & 3.70 & 3.84 \\
\hline 1 & $15-2150$ & 5.74 & 19 & 5.80 & 3.95 \\
\hline 1 & $15-2215$ & 5.1 & 13 & 7.71 & 4.03 \\
\hline 2 & $15-2430$ & 5.03 & 11 & 7.60 & 4.09 \\
\hline 1 & $87-2102$ & 4.67 & 8 & 8.05 & 4.14 \\
\hline 2 & $15-1783$ & 3.84 & 11 & 11.95 & 4.18 \\
\hline 2 & $15-1621$ & 3.43 & 7 & 11.60 & 4.22 \\
\hline 2 & $15-1639$ & 3.19 & 15 & 15.67 & 4.26 \\
\hline 2 & $15-2215$ & 2.68 & 13 & 17.00 & 4.29 \\
\hline 2 & $87-2102$ & 1.81 & 12 & 19.88 & 4.31 \\
\hline 1 & $15-1621$ & 1.80 & 10 & 18.82 & 4.34 \\
\hline 3 & $15-1243$ & 1.80 & 4 & 13.50 & 4.36 \\
\hline 3 & $15-1225$ & 1.71 & 7 & 16.99 & 4.38 \\
\hline 3 & $15-2430$ & 1.6 & 3 & 12.44 & 4.40 \\
\hline 1 & $15-1783$ & 1.49 & 4 & 14.30 & 4.42 \\
\hline 1 & $15-868$ & 1.48 & 8 & 18.57 & 4.43 \\
\hline 1 & $15-1639$ & 1.33 & 7 & 18.21 & 4.45 \\
\hline 2 & $15-2150$ & 1.2 & 7 & 18.61 & 5.07 \\
\hline 1 & $15-2430$ & 1.2 & 4 & 15.04 & 5.11 \\
\hline 1 & $15-1243$ & 1.12 & 4 & 15.25 & 5.14 \\
\hline 2 & $15-1176$ & 1.10 & 7 & 18.93 & 5.17 \\
\hline 3 & $15-1783$ & 1.08 & 6 & 17.96 & 5.21 \\
\hline 1 & $15-2001$ & 1.07 & 5 & 16.80 & 5.23 \\
\hline 3 & $15-1639$ & 0.93 & 5 & 17.17 & 5.26 \\
\hline 1 & $15-1225$ & 0.85 & 5 & 17.41 & 5.29 \\
\hline 2 & $15-2001$ & 0.81 & 14 & 24.67 & 5.32 \\
\hline 3 & $15-1621$ & 0.71 & 6 & 19.06 & 5.34 \\
\hline 1 & $15-1649$ & 0.67 & 9 & 22.08 & 5.36 \\
\hline 1 & $15-1110$ & 0.62 & 3 & 14.66 & 5.39 \\
\hline 1 & $15-874$ & 0.61 & 3 & 14.68 & 5.41 \\
\hline 2 & $15-868$ & 0.45 & 3 & 15.04 & 5.43 \\
\hline 3 & $15-2001$ & 0.40 & 2 & 12.70 & 5.45 \\
\hline 2 & $15-1110$ & 0.23 & 7 & 21.66 & 5.47 \\
\hline 2 & $15-1649$ & 0.14 & 7 & 21.95 & 5.49 \\
\hline 2 & $15-874$ & 0.13 & 10 & 24.77 & 5.51 \\
\hline
\end{tabular}


In the next step, the next largest mean of flow unit 1 of $15-2150$ is compared with the smallest mean (flow unit 2 of 15-874).

$$
\left(\begin{array}{ll}
5.74 & 0.13
\end{array}\right) \sqrt{\frac{2(19)(10)}{19 \quad 10}} \quad 24.77
$$

Table F . 8 C omparison of the mean of flow unit 1 of well 15-2150.

\begin{tabular}{cccccc} 
Flow Unit & Well & $\begin{array}{c}\text { Predicted } \\
\text { Perm (mD) }\end{array}$ & $\begin{array}{c}\text { Number of Data } \\
\text { in Zone }\end{array}$ & $\begin{array}{c}\text { F'p for } \\
\mathbf{5 . 7 4}\end{array}$ & $\mathbf{F}$ 'p \\
\hline 1 & $15-2150$ & 5.74 & 19 & & \\
1 & $15-2215$ & 5.1 & 13 & 2.51 & 3.69 \\
2 & $15-2430$ & 5.03 & 11 & 2.65 & 3.84 \\
1 & $87-2102$ & 4.67 & 8 & 3.59 & 3.95 \\
\hline \hline 2 & $15-1783$ & 3.84 & 11 & 7.09 & 4.03 \\
2 & $15-1621$ & 3.43 & 7 & 7.40 & 4.09 \\
2 & $15-1639$ & 3.19 & 15 & 10.46 & 4.14 \\
2 & $15-2215$ & 2.68 & 13 & 12.02 & 4.18 \\
2 & $87-2102$ & 1.81 & 12 & 15.07 & 4.22 \\
1 & $15-1621$ & 1.80 & 10 & 14.25 & 4.26 \\
3 & $15-1243$ & 1.80 & 4 & 10.12 & 4.29 \\
3 & $15-1225$ & 1.71 & 7 & 12.88 & 4.31 \\
3 & $15-2430$ & 1.6 & 3 & 9.42 & 4.34 \\
1 & $15-1783$ & 1.49 & 4 & 10.93 & 4.36 \\
1 & $15-868$ & 1.48 & 8 & 14.29 & 4.38 \\
1 & $15-1639$ & 1.33 & 7 & 14.12 & 4.40 \\
2 & $15-2150$ & 1.2 & 7 & 14.52 & 4.42 \\
1 & $15-2430$ & 1.2 & 4 & 11.67 & 4.43 \\
1 & $15-1243$ & 1.12 & 4 & 11.88 & 4.45 \\
2 & $15-1176$ & 1.10 & 7 & 14.85 & 5.07 \\
3 & $15-1783$ & 1.08 & 6 & 14.07 & 5.11 \\
1 & $15-2001$ & 1.07 & 5 & 13.15 & 5.14 \\
3 & $15-1639$ & 0.93 & 5 & 13.52 & 5.17 \\
1 & $15-1225$ & 0.85 & 5 & 13.76 & 5.21 \\
2 & $15-2001$ & 0.81 & 14 & 19.78 & 5.23 \\
3 & $15-1621$ & 0.71 & 6 & 15.19 & 5.26 \\
1 & $15-1649$ & 0.67 & 9 & 17.71 & 5.29 \\
1 & $15-1110$ & 0.62 & 3 & 11.65 & 5.32 \\
1 & $15-874$ & 0.61 & 3 & 11.68 & 5.34 \\
2 & $15-868$ & 0.45 & 3 & 12.04 & 5.36 \\
3 & $15-2001$ & 0.40 & 2 & 10.17 & 5.39 \\
2 & $15-1110$ & 0.23 & 7 & 17.62 & 5.41 \\
2 & $15-1649$ & 0.14 & 7 & 17.91 & 5.43 \\
2 & $15-874$ & 0.13 & 10 & 20.31 & 5.45 \\
& & & & &
\end{tabular}


At the completion of the test, it was found that the comparisons are significant until flow unit 2 of 87-2102 is reached as shown in Table F.8. At this point, another comparison was begun with the next largest mean using the smaller mean. The comparisons continued until the differences are not significant and less than the values of corresponding $\mathrm{FG}_{\mathrm{p}}$ values. Therefore, these groups of flow units are significantly correlated with each other.

Finally, the means distinguished as separate groups, which are not significantly different are shown in Table F.9. 
Table F . 9 Final division of core permeability means into five groups.

\section{Group 1}

\begin{tabular}{cc} 
Flow Unit & W ell \\
\hline 1 & $15-1176$ \\
2 & $15-1243$ \\
2 & $15-1225$ \\
\hline \hline
\end{tabular}

Group 2

\begin{tabular}{cc} 
Flow Unit & Well \\
\hline 1 & $15-2150$ \\
1 & $15-2215$ \\
2 & $15-2430$ \\
1 & $87-2102$ \\
\hline \hline
\end{tabular}

Group 3

\begin{tabular}{cc} 
Flow Unit & Well \\
\hline 2 & $15-1783$ \\
2 & $15-1621$ \\
2 & $15-1639$ \\
\hline \hline
\end{tabular}

Group 5

\begin{tabular}{cc} 
Flow Unit & Well \\
\hline 2 & $15-1110$ \\
2 & $15-1649$ \\
2 & $15-874$ \\
\hline \hline
\end{tabular}

Group 4

\begin{tabular}{cc} 
Flow Unit & W ell \\
\hline 2 & $15-2215$ \\
2 & $87-2102$ \\
1 & $15-1621$ \\
3 & $15-1243$ \\
3 & $15-1225$ \\
3 & $15-2430$ \\
1 & $15-1783$ \\
1 & $15-868$ \\
1 & $15-1639$ \\
2 & $15-2150$ \\
1 & $15-2430$ \\
1 & $15-1243$ \\
2 & $15-1176$ \\
3 & $15-1783$ \\
1 & $15-2001$ \\
3 & $15-1639$ \\
1 & $15-1225$ \\
2 & $15-2001$ \\
3 & $15-1621$ \\
1 & $15-1649$ \\
1 & $15-1110$ \\
1 & $15-874$ \\
2 & $15-868$ \\
3 & $15-2001$ \\
\hline \hline
\end{tabular}

